\title{
Правова Позиція
}

\section{(правонаступник наукового журналу}

“Вісник Академії митної служби України.

\section{Серія: "Право")}

\section{№ 3 (24)}

Включено до Переліку наукових фахових видань Украӥни, у яких можуть публікуватися результати дисертаційних робіт з юридичних наук (Наказ Міністерства освіти і науки України від 16.05.2016 p. № 515, додаток 11)

\section{Дніпро}

Університет митної справи та фінансів

2019 


\author{
Правова позиція \\ (правонаступник наукового журналу “Вісник Академії митної служби України. \\ Серія: "Право") \\ Науковий журнал \\ Видається чотири рази на рік
}

Рекомендовано до друку та до поширення через мережу Інтернет вченою радою

Університету митної справи та фінансів (протокол № 2 від 30.08.2019)

\title{
«Правова позиція» включено до міжнародної наукометричної бази
} Index Copernicus International (Республіка Польща)

\author{
Редакиійна колегія: \\ Приймаченко Д. В. - д.ю.н., проф. \\ (головний редактор); \\ Кунєв Ю. Д. - д.ю.н., проф. \\ (заступник головного редактора); \\ Дерев'янко Т. П. (відповідальний секретар); \\ Александров О. С. - д.ю.н., проф., \\ Нижньогородська академія МВС РФ; \\ Бевзенко В. М. - д.ю.Н., проф.; \\ Гелерт Лотар - д.ю.Н., проф., Німецький \\ урядовий університет державного управління \\ (Федеративна Республіка Німеччини); \\ Гетьман А. П. - д.ю.н., проф., член-кореспон- \\ дент Національної академії правових наук Укра- \\ їни, лауреат Державної премії, заслужений діяч \\ науки і техніки України; \\ Грищук В. К. - д.ю.н., проф., академік \\ Національної академії правових наук України; \\ Додін Є. В. - д.ю.н., проф., \\ заслужений діяч науки і техніки України; \\ Доненко В. В. - д.ю.н., доц.; \\ Задихайло Д. В. - Д.ю.н., проф., \\ заслужений працівник освіти України;
}

\author{
Колпаков В. К. - д.ю.Н., проф.; \\ Легеза Є. О. - д.ю.н., проф.; \\ Малишев Б. В. - д.ю.н., проф.; \\ Михайлов В. О. - Д.ю.н., проф., \\ Російська митна академія, \\ заслужений юрист РФ; \\ Мінка Т. П. - д.ю.н., доц.; \\ Мішук М. О. - д.ю.н., доц.; \\ Рабінович С. П. - д.ю.н., проф.; \\ Раковський Мачей - Лодзький університет, \\ (Республіка Польща); \\ Сабо Андреа - доктор наук, проф., \\ Університет публічної служби \\ (Угорська Республіка); \\ Тертишник В. М. - Д.ю.н., проф.; \\ Чижович Всслав - доктор наук у галузі \\ митної політики та митного права, проф., \\ Головна торгова школа у Варшаві \\ (Республіка Польща); \\ Щербина В. I. - д.ю.н., проф.; \\ Яковюк І. В. - д.ю.н., проф.; \\ Яроцький В. Л. - Д.ю.н., проф., \\ заслужений діяч науки і техніки України.
}

\section{ISSN 2521-6473}

Коректори: Н. В. Пірог, Н. С. Ігнатова

Комп’ютерна верстка: Ю. С. Семенченко

Свідоцтво про державну реєстрацію: серія КВ № 21947-11847ПР від 31.12.2015 p.

Адреса: м. Дніпро, вул. Володимира Вернадського, 2/4, 49000 Тел.: +38 (099) 7296379

Електронна адреса: editor@legalposition.umsf.in.ua

Видавництво і друкарня - Видавничий дім «Гельветика»

73021, м. Херсон, вул. Паровозна, 46-a, офіс 105

Телефон +38 (0552) 39-95-80

E-mail: mailbox@helvetica.com.ua

Свідоцтво суб'єкта видавничої справи ДК № 6424 від 04.10.2018 p.

Підписано до друку 02.09.2019. Формат 60×84/16. Папір офсетний.

Гарнітура Таймс. Ум. друк. арк. 8,14. Обл.-вид. арк. 12,64.

Наклад 300 прим. Замовлення № 0919/192. 


\section{MICT}

\section{ІСТОРІЯ ТА ТЕОРІЯ ПРАВА}

О. С. Олійник. Ієрархія принципів кримінального права України

\section{АДМІНІСТРАТИВНЕ ТА МИТНЕ ПРАВО}

А. В. Бойко. Адміністративний процес та адміністративна процедура: зміст категорій та їх співвідношення (окремі аспекти дискусії)

І. Л. Желтобрюх. Адміністративний процес у сучасній доктрині адміністративного права як сфера об'єктивізації статусу сторін судочинства

А. В. Замрига. «Адміністративна сервісність» як ознака діяльності публічної адміністрації у сфері адміністративно-правового забезпечення господарської діяльності в Україні

Л. О. Золотухіна. Прояв публічного інтересу в окремих різновидах адміністративних правовідносин

О. Л. Коліуш. Удосконалення правового регулювання та системи інформаційного забезпечення як напрям запобігання корупції під час надання адміністративних послуг

С. П. Параниця, А. В. Алентьєва. Правовий статус відповідального працівника суб'єкта первинного фінансового моніторингу ....

М. М. Потіп. Акт застосування права як засіб публічного управління та правового регулювання у сфері приватизації

О. М. Правоторова. Особливості ефективності адміністративно-правової охорони

Т. М. Савченко. Система суб'єктів адміністративно-правового регулювання в галузі мисливського господарства та полювання

В. В. Сагайдак. Майно як об'єкт оподаткування.

М. І. Соф’їн. До проблеми подолання корупції в Україні в контексті розробки концептуальних засад удосконалення фіскальної політики

О. П. Цуркан. Мета професійного навчання поліцейських України

\section{ЦИВІЛЬНЕ ПРАВО}

П. Д. Гуйван. Українське та міжнародне правове опосередкування доступу особи до інформації

\section{ПРОБЛЕМИ ПРАВООХОРОННОЇ ДІЯЛЬНОСТІ}

О. Ю. Дудченко. Правоохоронна функція як одна з форм реалізації державної влади

В. О. Поповичук. Вдосконалення законодавства України про кримінальну відповідальність за незаконне використання символіки Червоного Хреста, Червоного Півмісяця, Червоного Кристала. 


\section{ТРИБУНА МОЛОДОГО НАУКОВЦЯ}

С. С. Аліна. Фактори традиційного спадкування цифрових об'єктів. 119

Є. В. Баранова. Право на захист викривачів корупції: конституційний аспект 124 О. І. Лук'янчук. Порядок примусового стягнення аліментів на користь батьків за сімейним законодавством України 129

к. Д. Пономаренко. Поняття забудови як форми реалізації цивільного права на забудову. 


\section{CONTENTS}

\section{HISTORY AND THEORY OF LAW}

O. S. Oliinyk. Hierarchy of the principles of criminal law of Ukraine.

\section{ADMINISTRATIVE AND CUSTOMS LAW}

A. V. Boiko. Administrative process and administrative procedure: contents of the categories and their relations (some aspects of discussion)

I. L. Zheltobruh. Administrative procedure in the modern doctrine of administrative law as a sphere of objectivization of the status of parties of legal proceedings

A. V. Zamryha. "Administrative service-based nature" as a feature of public administration activities in administrative and legal support of business activity in Ukraine.

L. O. Zolotukhina. Public interest in certain types of administrative legal relationships.

O. L. Koliush. Improvement of legal regulation and data intelligence system as directions to prevent corruption during provision of administrative services

S. P. Paranytsia, A. V. Alentyeva. Legal status of the responsible employee of the principal financial monitor subject

M. M. Potip. Act of applying law as a means of public administration and legal regulation in the sphere of privatization

O. M. Pravotorova. Features of effectiveness of administrative legal protection.

T. M. Savchenko. The system of subjects of administrative and legal regulation in hunting economy and shooting.....

V. V. Sahaidak. Property as an object of taxation

M. I. Sofin. To the problem of overcoming corruption in Ukraine in the context of developing the conceptual framework for fiscal policy improvement.

O. P. Tsurkan. The purpose of professional training the police officers of Ukraine 90

\section{CIVIL LAW}

P. D. Guyvan. Ukrainian and international legal mediation of a person's access to information.

\section{PROBLEMS OF LAW ENFORCEMENT ACTIVITIES}

A. Yu. Dudchenko. Law enforcement function as one of the forms of state power realization

V. O. Popovichuk. Senior investigator on especially important cases chief financial investigator investigations of the state fiscal service of Ukraine...... 


\section{TRIBUNE OF A YOUNG SCIENTIST}

S. S. Alina. Factors excluding the possibility of traditional inheritance of digital objects.

E. V. Baranova. Right of whistleblower's legal protection: constitutional aspect

124

O. I. Lukyanchuk. The order of maintenance enforcement for parents upon the family law of Ukraine

K. D. Ponomarenko. Concept of development as a form of realization of civil law for development. 
УДК 343.01

DOI https://doi.org/10.32836/2521-6473-2019-3-7-13

\author{
О. С. Олійник, кандидат юридичних наук, \\ доцент, доцент кафедри кримінального права \\ та процесу \\ Київського національного економічного університету \\ імені Вадима Гетьмана
}

\title{
ІЄРАРХІЯ ПРИНЦИПІВ КРИМІНАЛЬНОГО ПРАВА УКРАЇНИ
}

У статті автор робить спробу вибудувати систему принципів кримінального права за ієрархією, спираючись на досвід, який був накопичений протягом тривалого часу. Критерієм відбору принципів для иього слугували сочіальна сутність та практична значимість останніх.

У дослідженні автор наводить думку, щчо першим в ієрархї загальноправових принщипів кримінального права повинен бути згаданий принцип справедливості. Приводяться думки вчених різних часів, які вважали, щзо справедливість - ие внутрішня властивість $і$ якість права, більш того, на їх думку, тільки право є справедливим. На користь обраної позиџї свідчать і положення Загальної деклараиї прав людини, i Міжнародного пакту про громадянські і політичні права, а також Протоколу № 6 до Європейської Конвениії про захист прав людини і основних свобод.

Доводиться, щчо принци справедливості повинен виступати арбітром в ситуаціях, коли виникають певні протиріччя між іншими принципами кримінальної відповідальності. Водночас в основі права як системи завжди лежить не одне вихідне положення, не один принцип, а принаймні кілька, причому вони не иілком збігаються за змістом.

На другому місиі, на думку автора, повинні стояти два практично рівнозначних принципи: иче принцип законності та принцип верховенства права. Так, перший із них повинен чітко визначати, які суспільно небезпечні діяння повинні вважатися злочинними, інший - правильно розставляти акценти, відповідно до яких на перший план повинні виходити загальнолюдські цинності.

Далі автор називає такий принции, як принции юридичної (правової) визначеності, адже він є одним із суттєвих елементів принципу верховенства права і відповідає, по суті, за ясність і чіткість закону. Потім принцип рівності громадян перед законом, який закріплений на конституиійному рівні. І останній - принцип гуманізму. Висловлюється думка про те, щзо тенденція гуманізаиії законодавства не повинна суперечити концепчії пріоритетної охорони прав і свобод людини та громадянина, $і$ на перший план тут повинні виступати інтереси, права та свободи особи, яка потерпіла від злочину, а не особи, яка його вчинила.

Ключові слова: право, принциипи кримінального права, ієрархія принщипів права, принщип справедливості, принции верховенства права, принциип законності.

\section{O. S. Oliinyk. Hierarchy of the principles of criminal law of Ukraine}

In the article, the author makes an attempt to build a system of principles of criminal law in a hierarchy, based on the experience that has accumulated humanity for a long time. The social essence and practical significance of the latter served as the criteria for the selection of principles for this.

In the study, the author gives the opinion that the principle of justice should be mentioned first in the hierarchy of general legal principles of criminal law. The opinions of scholars of different times are given who believed that justice is an internal property and quality of law, moreover, in their opinion, only law is fair. This position is also supported by the provisions of the Universal Declaration of Human Rights, and the International Covenant on Civil and Political Rights, as well as Protocol No. 6 to the European Convention for the Protection of Human Rights and Fundamental Freedoms.

It is proved that the principle of justice should act as an arbiter in situations when certain contradictions arise between other principles of criminal liability. At the same time, the basis of law as a system is always not one initial position, not one principle, but at least several, and they do not completely coincide in content.

(C) О. С. Олійник, 2019

ISSN 2521-6473

Правова позиція, № 3 (24), 2019 
In the second place, according to the author, there should be two practically equivalent principles: this is the principle of legality and the rule of law. So, the first of them should clearly determine what socially dangerous acts should be considered criminal, the other should correctly place accents, according to which universal values should come to the fore.

Further, the author calls such a principle as the principle of legal (legal) certainty, because it is one of the essential elements of the rule of law and is essentially responsible for the clarity and clarity of the law. Then the principle of equality of citizens before the law, enshrined at the constitutional level. And the last is the principle of humanism. It is suggested that the trend of humanizing legislation should not contradict the concept of priority protection of human and civil rights and freedoms. And the forefront here should be the interests, rights and freedoms of the person affected by the crime, and not the person who committed it.

Key words: law, principles of criminal law, hierarchy of principles of law, principle of justice, principle of the rule of law, legality.

Постановка проблеми. Поняття «принцип» не $\epsilon$ суто кримінально-правовим, а бере свій початок із визначення, виробленого філософією, де принцип визначено як першооснову, керівну ідею, основне правило поведінки.

На думку В.Д. Філімонова, ознаки принципів кримінального права полягають в тому, що такі принцип - це: 1) початкові і відправні положення кримінального права, з урахуванням яких формується зміст його норм; 2) вимога, обов'язкова для законодавця, правозастосовчих органів і громадян у сфері боротьби зі злочинністю; 3) положення, що має для кримінального законодавства наскрізний характер; 4) вимога, що має стійкий характер; 5) положення, яке отримало юридичне вираження в кримінально-правових нормах [1, с. 29-31].

Не вдаючись до детального аналізу згаданих вище понять, в нашому дослідженні ми спробуємо вибудувати систему принципів кримінального права за ієрархією.

Аналіз останніх досліджень і публікацій. Питанням з'ясування сутності окремих принципів кримінального права були присвячені роботи таких вітчизняних та зарубіжних науковців, як П.С. Берзін, В.О. Гацелюк, О.О. Дудоров, С.Г. Келіна, В.Н. Кудрявцев, М.А. Малигіна, М.В. Мазур, В.В. Мальцев, В.О. Навроцький, В.Д. Філімонов, Д.Ю. Фісенко, Є.Є. Чередніченко та багато інших.

Метою статті $\epsilon$ спроба побудови системи принципів кримінального права України за ієрархією, беручи до уваги соціальну сутність та практичну значимість останніх.

Виклад основного матеріалу дослідження. Відразу ж зазначимо, що свого часу геніальні уми людства, які існували протягом всієї історії цивілізації, змогли розгледіти реальну тенденцію у всесвітньому законодавстві - його гуманізацію, а отже, перемогу справедливості.

Мислителі всіх часів, починаючи з рабовласницької доби (Сократ, Платон, Аристотель, Цицерон, Папініан, Ульпіан, Гай, Модестин, Павло), феодальної (А. Августин, Ф. Аквінський, М. Падуанський), буржуазної (Г. Гроцій, Б. Спіноза, Т. Гоббс, Д. Локк, Ж.Ж. Руссо, Ш. Монтеск'є) і закінчуючи відомими сучасними правознавцями (Р. Дворкін, В.С. Нерсесянц та багато інших), виходять з того, що головне в праві - справедливість. Академік В.С. Нерсесянц справедливо підкреслює: «справедливість - внутрішня властивість і якість права», «більш того, тільки право $\epsilon$ справедливим», «справедливо те, що виражає право, відповідає праву і слідує праву», «право - це загальна справедливість» [2, с. 65-66, 71]. Звичайно, кожній епосі відповідає своя соціальна справедливість, однак вона завжди залишається такою за визначенням, не кажучи вже про воістину вічні загальнолюдські цінності (свободу, рівність, безпеку тощо).

Отже, сутністю права як фактора, що безпосередньо визначає його принципи та певною мірою знаходить в них свою конкретизацію, є справедливість, а точніше - політична загальносоціальна справедливість як баланс інтересів всіх соціальних груп, особистості і суспільства, яку і повинні виражати посланці народу - депутати парламентів - в процесі здійснення останніми їх законодавчої діяльності. 
На думку В.К. Бабаєва, «принципи права - основоположні ідеї, начала, які виражають сутність права і випливають з генеральних ідей справедливості і свободи» [3, с. 128].

У науковій літературі називають різну кількість принципів кримінального права, одні - 7, інші - 9. Насправді ж їх значно більше. I чим прискіпливіше підходити до наявних у праві власне правових принципів, тим краще вони будуть служити практичному закріпленню (встановленню) саме правових норм та їх ефективній реалізації.

В окремих галузях принципи права навіть знайшли своє текстуальне закріплення (кримінально-процесуальне законодавство, цивільно-процесуальне законодавство тощо). Водночас залишаються сфери суспільних відносин, де принципи не знайшли свого відображення. Серед останніх і кримінальне законодавство.

Серед загальноправових принципів, які визначають саме кримінальне право як галузь права, в літературі згадуються: принцип справедливості (принцип соціальної справедливості), принцип верховенства права, принцип законності, принцип гуманізму, принцип рівності громадян перед законом та принцип юридичної (правової) визначеності. До галузевих принципів слід віднести: принцип невідворотності кримінальної відповідальності; принцип винної відповідальності; принцип особистості під час застосування заходів кримінально-правового характеру; принцип застосування заходів кримінально-правового характеру за вчинення суспільно небезпечного діяння, визначеного у КК; принцип індивідуалізації застосування заходів кримінально-правового характеру та принцип диференціації заходів кримінально-правового характеру.

Та якщо визначити ієрархію галузевих (спеціальних) принципів кримінального права доволі складно, бо діють вони зазвичай одночасно і взаємозумовлені один одним, то здійснити подібну операцію із загальноправовими принципами ми вважаємо за можливе.

Отже, як зазначалось нами вище, найвищий щабель у ієрархії принципів кримінального права повинен займати саме принцип справедливості (принцип соціальної справедливості), бо ця галузь права із самого початку започатковувалась для того, щоб відновити справедливість в разі вчинення особою суспільно небезпечного діяння, яке спричиняло шкоду державі, суспільству, окремій особі або створювало загрозу заподіяння такої шкоди. В різні часи для цього вироблялись (обирались) відповідні шляхи (способи): помста («око за око, зуб за зуб»), розплата (компенсація) грошовими коштами, усунення від посади, тюремне ув'язнення, вигнання тощо.

На користь обраної нами позиції свідчать і положення ст. 10 Загальної декларації прав людини, яке встановлює, що: «Кожна людина, для визначення іiї прав і обов’язків і для встановлення обгрунтованості пред’явленого їй кримінального обвинувачення, має право, на основі повної рівності, на те, щоб іiі справа була розглянута прилюдно і з додержанням усіх вимог справедливості незалежним і неупередженим судом» [4]. У ст. 14 Міжнародного пакту про громадянські і політичні права сказано: «Кожен має право при розгляді будь-якого кримінального обвинувачення, висунутого проти нього, або при визначенні його прав і обов'язків у будь-якому цивільному процесі на справедливий і публічний розгляд справи компетентним, незалежним і безстороннім судом, створеним на підставі закону» [5]. Вимога, схожа з наведеними, міститься і в ст. 6 Протоколу № 6 до Європейської Конвенції про захист прав людини і основних свобод.

Принцип справедливості виступає арбітром в ситуаціях, коли виникають певні протиріччя між іншими принципами кримінальної відповідальності. Про такі ситуації згадували в своїй роботі ще С.Г. Келіна і В.Н Кудрявцев. Вони зазначали, що «вихідні посилання правових конструкцій у багатьох відношеннях суперечливі, оскільки вони відображають реальні суперечності суспільного життя. Право покликане регулювати протиріччя, що виникають. Звідси випливає, що в основі права як системи завжди лежить не одне вихідне положення, не 
один принцип, а принаймні кілька, причому вони не цілком збігаються за змістом». Згадані автори вказують, зокрема, на протиріччя між принципами рівності громадян перед законом і справедливості відповідальності (індивідуалізації). На їхню думку, «це протиріччя неминуче, воно закладено в самій суті права, як регулятора відносин між людьми». В результаті своїх спостережень вони дійшли висновку: «Це не означає, що в основі законодавства і практики його застосування можуть бути покладені принципи, що суперечать один одному. Водночас це означає, що під час виконання кримінальним правом того чи іншого завдання на перший план виступає то один, то інший правовий принцип, що не скасовує, проте, дії інших принципів». Таким чином, С.Г. Келіна і В.Н. Кудрявцев вважають, що в разі суперечності принципів один одному перевага повинна віддаватися тому, який найбільшою мірою відповідає виконанню того чи іншого завдання, що стоїть перед кримінальним правом [6].

Друге місце, на нашу думку, повинні займати такі принцип, як принцип законності та принцип верховенства права.

Принцип законності втілений у ст. 3 КК України, що встановлює: «Законодавство України про кримінальну відповідальність становить Кримінальний кодекс України, який грунтується на Конституції України та загальновизнаних принципах і нормах міжнародного права. Злочинність діяння, а також його караність та інші кримінально-правові наслідки визначаються тільки цим Кодексом. Застосування кримінального закону за аналогією заборонено» [7].

Принцип законності в кримінальному праві означає, що всі положення, які лежать в основі притягнення особи до кримінальної відповідальності за скоєне, призначення покарання, звільнення від нього або настання інших кримінально-правових наслідків вчинення злочину, повинні бути сформульовані винятково в законі як у вищому акті законодавчої влади, тобто єдине джерело кримінального права - кримінальний закон.

О.О. Дудоров і М.В. Мазур зазначають, що принцип законності означає сухе дотримання букви закону, а принцип верховенства права допускає певне відхилення від нього, висуваючи на перший план пріоритетність прав і свобод людини і громадянина. Як наполягають згадані автори, на практиці ставлення до співвідношення цих принципів різниться. Так, суддя Вищого спеціалізованого суду з розгляду цивільних і кримінальних справ Д.Д. Луспеник наголошує, що «верховенство права має стати стандартом судового правотлумачення і судового правозастосування, елементами якого < ..> повинні бути такі формальні елементи, як законність (в сенсі правових законів), правова визначеність, пропорційність і право на справедливий судовий розгляд, а субстативним елементом має стати визнання пріоритетності прав людини». При цьому законність у контексті європейського підходу до верховенства права і практики ЄСПЛ «не може зводитись до простої відповідності нормам матеріального та процесуального права і розглядається дещо ширше...»

Зазначимо, що О.О. Дудоров у своїх попередніх роботах наполягав на пріоритетності принципу законності під час вирішення кримінальних справ, а М.В. Мазур, як практикуючий суддя, наполягав на пріоритетності принципу верховенства права в таких випадках. Однак спільно проведена ними робота на основі аналізу рішень Токійського та Нюрнберзького трибуналів переконливо доводить, що в історії бувають випадки, коли навіть принцип законності може відійти на другий план задля справедливості судового рішення.

Дійсно, ці принципи доволі щільно переплітаються між собою. Так, згадані вище автори під час здійснення аналізу міжнародного досвіду та практики Європейського суду з прав людини в своїй роботі дійшли наступних висновків. Під час вирішення питання про співвідношення згаданих принципів міжнародні та закордонні суди керуються підходом, який відомий як «формула Радбруха», відповідно до якої правова стабільність, забезпечувана формальною законністю, з позиції верховенства права, так само є цінністю, як і справедливість, 
і доцільність. Тому коли виникають ситуації, і закон може справляти враження несправедливого закону, він підлягає застосуванню. Адже саме на законодавця покладається обов'язок під час ухвалення закону знаходити розумний баланс між засадами справедливості і доцільності 3 погляду загального блага. Окрім того, зазначають автори, справедливість може мати суб'єктивний характер, і що може видаватись справедливим для одного, для іншого - несправедливо. I саме в такій ситуації закон виступає мірилом справедливості під час вирішення конкретних справ. Водночас у виняткових ситуаціях, коли закон сам по собі через його викривлену інтерпретацію чи поширену практику його застосування призводить до несправедливості, що несумісна з базовими загальнолюдськими принципами і цінностями, які знаходять закріплення в міжнародному праві, такий закон або не повинен застосовуватись взагалі, або має тлумачитись у спосіб, який дозволяє узгодити його зміст із вказаними принципами і цінностями [8].

Отже, верховенство права у сучасному розумінні не скасовує принципу законності, а навпаки, розвиває його до нової якості - панування права від суто формальних вимог «дотримання закону» до інших, надпозитивних чинників змісту права. Саме тому ці принципи, на наше переконання, заслуговують знаходитись практично на одному рівні.

Слідком за цими принцами повинен йти принцип юридичної (правової) визначеності, адже він $є$ одним із суттєвих елементів принципу верховенства права. Приводом для остаточного визнання цього принципу стало рішення Конституційного Суду від 26 лютого 2019 року у справі за конституційним поданням 59 народних депутатів України щодо відповідності Конституції України (конституційності) статті 368-2 Кримінального кодексу України, в п. 3 якого говориться, що одним з головних елементів принципу верховенства права, закріпленого ч. 1 ст. 8 Основного Закону України, є юридична визначеність. Конституційний Суд України наголошував на важливості вимоги визначеності, ясності і недвозначності правової норми, оскільки інше не може забезпечити ii однакове застосування, не виключає необмеженості трактування у правозастосовній практиці і неминуче призводить до сваволі (абзац 2 підпункту 5.4 пункту 5 мотивувальної частини Рішення від 22 вересня 2005 року № 5-рп/2005).

Наступним повинен називатись принцип рівності громадян перед законом, який також закріплений і на конституційному рівні. Основу змісту принципу рівності громадян перед законом у кримінальному праві становлять вимоги рівних підстав для застосування кримінальної відповідальності і рівних критеріїв визначення змісту і розмірів кримінальної відповідальності.

У національному кримінальному праві рівність громадян перед законом забезпечується насамперед визнанням наявності в діянні особи складу злочину, передбаченого законом, єдиною підставою притягнення iї до кримінальної відповідальності. Сукупність ознак, які точно визначені в законі і характеризують діяння як злочин, є тим зрозумілим і очевидним «єдиним масштабом», який забезпечує реалізацію рівного для всіх обов'язку понести відповідальність за вчинення злочину.

Вищесказане доводить, що цей принцип є похідним від принципу законності та верховенства права.

Останнім у нашому списку (однак не за важливістю) виступає принцип гуманізму. Кримінально-правовий зміст розглядуваного принципу, окрім завдання, передбаченого ч. 1 ст. 1 КК, так би мовити, включає в себе також «способи» його виконання. Вказані «способи» не переслідують при цьому мету помсти особі, яка порушила кримінально-правову норму-заборону, шляхом заподіяння їй фізичних страждань, приниження пї честі та гідності. Вплив держави на таку особу полягає в певному законодавчо визначеному обмеженні іiі прав і свобод, у прагненні добитися іiі виправлення та запобігти вчиненню нею та іншими особами «кримінально-правових аномалій». Деякі зі способів виконання завдань, що стоять перед кримінальним законом та вказані в ньому, тісно пов'язані із засадами гуманізму. Показником дійсного здійс-

ISSN 2521-6473

Правова позиція, № 3 (24), 2019 
нення, а не тільки декларативного закріплення цього принципу, є встановлені кримінальним законом відношення і міра дозволеного примусу, що застосовується за законом до особи, яка вчинила злочин. Це насамперед стосується положень, визначених у ч. 3 ст. 50 КК, де законодавець прямо заперечив таку мету покарання, як завдання засудженому фізичних страждань або приниження людської гідності. Принцип гуманізму знайшов свою реалізацію і в положенні ст. 52 КК, де говориться про те, що «за один злочин може бути призначено лише одне основне покарання, передбачене в санкції статті (санкції частини статті) Особливої частини КК (ч. 4)». Отже, можна стверджувати, що принцип гуманізму заперечує застосування видів покарання, що характеризуються жорстокістю, особливою ганебністю та мученням стосовно засудженого $[9$, c. 136].

Отже, сучасний погляд на принцип гуманізму кримінального права полягає у включенні до останнього наступних положень:

- забезпечення прав людини кримінальним законодавством;

- гуманізацію кримінально-правової політики держави, а саме: скорочення кола осіб, які підлягають кримінальній відповідальності (за рахунок неосудних, осіб, які не досягли віку кримінальної відповідальності, тощо);

- обмеження заходів, які застосовуються до особи, що вчинила злочин, лише мінімально необхідними та достатніми для досягнення цілей їх виправлення та превенції;

- розробка та впровадження альтернативних кримінальному покаранню заходів впливу на особу, що вчинила злочин;

- заборона моделювання та застосування будь-яких заходів впливу на особу, що вчинила злочин, з метою спричинення фізичних або психічних страждань [10].

Водночас ми переконані, що принцип гуманізму не повинен домінувати над іншими принципами кримінального права, насамперед над принципом справедливості, тенденція гуманізації законодавства не повинна суперечити концепції пріоритетної охорони прав і свобод людини та громадянина. I на перший план тут повинні виступати інтереси, права та свободи особи, яка потерпіла від злочину, а не особи, яка його вчинила.

Висновки 3 дослідження і перспективи подальших розвідок у цьому напрямі. Таким чином, на перше місце в ієрархії загальноправових принципів кримінального права ми запропонували поставити принцип справедливості. Його особливе місце зумовлено такими обставинами: 1) принцип справедливості охоплює своїм змістом всі інші принципи. Останні, по суті, конкретизують його. Порушення будь-якого з цих принципів тягне одночасно і порушення принципу справедливості; 2) принцип справедливості визначає зміст інших принципів. Однак це не виключає того, що юридичне вираження того чи іншого принципу в нормах кримінального права може бути невдалим або не зовсім вдалим. Воно може зажадати коригування та вдосконалення; 3) під час виникнення правових колізій в процесі розробки кримінального законодавства або в процесі його застосування питання має вирішуватися відповідно до принципу справедливості. Він не може вирішуватися інакше, тому що рішення, що йде врозріз 3 цим принципом, не може бути прийнято суспільством. Далі на один щабель ми поставили принцип законності та верховенства права через їх формальну визначеність та виняткову практичну значимість. Адже без існування закону, правил поведінки, забезпечених примусом з боку держави в розглядуваній сфері суспільних відносин, всі попередньо висловлені нами тези можуть претендувати лише на статус наукових теорій та пошуків. Далі був названий принцип юридичної (правової) визначеності, адже неможливо переоцінити важливість вимоги визначеності, ясності і недвозначності правової норми, оскільки інше не може забезпечити iii однакове застосування, не виключає необмеженості трактування у правозастосовній практиці і неминуче може призвести до сваволі. Наступний - принцип рівності громадян перед 


\section{Історія та теорія права}

законом. Ми вважаємо це логічним, адже рівність не існуватиме без закріплення відповідних положень в законі, тобто без дотримання принципу законності. Водночас вже за дотримання принципу верховенства права є посилання і на принцип рівності всіх громадян перед законом. І останнім у нашому переліку названий принцип гуманізму. І це вважаємо справедливим, адже кримінальне право створювалось насамперед задля покарання тих осіб, які своїми діями спричиняли шкоду державі, суспільству чи окремим громадянам, а не для того, щоб забезпечити захист прав осіб, які безпосередньо вчинили злочин.

\section{Список використаних джерел:}

1. Филимонов В.Д. Принципы уголовного права. Москва, 2002. 139 с.

2. Нерсесянц В.С. Общая теория права и государства. Москва, 1999. 240 с.

3. Общая теория права / Под ред. В.К. Бабаева, Нижний Новгород, 1993. 521 с.

4. Загальна декларація прав людини. URL: http://zakon.rada.gov.ua/laws/show/995_015.

5. Міжнародний пакт про громадянські і політичні права. URL: http://zakon.rada.gov.ua/ laws/show/995_043.

6. Келина С.Г., Кудрявцев В.Н. Принципы советского уголовного права. Москва : Наука, 1988. 173c.;

7. Конституція України. URL: http://zakon.rada.gov.ua/laws/show/254\%D0\%BA/96$\% \mathrm{D} 0 \% \mathrm{~B} 2 \% \mathrm{D} 1 \% 80$.

8. Реалізація принципу верховенства права при застосуванні закону про кримінальну відповідальність: постановка проблеми, міжнародний і зарубіжний досвід. Юридичний науковий електронний журнал. 2017. № 5. C. 129-140. URL: http://www.lsej.org.ua/5_2017/36.pdf.

9. Берзін П.С. Кримінальне право України. Загальна частина : підручник : у 3-х т. Т. I. : Загальні засади. Київ : ВД «Дакор», 2018. 404 с.

10. Принципи (засади) кримінального права України (загальні, міжгалузеві, галузеві). URL: http://studies.in.ua/krimnalne-pravo-zagalna-chastina/4546-principi-zasadi-krimnalnogo-pravaukrayini-zagaln-mzhgaluzev-galuzev.html. 
УДК 342.9

DOI https://doi.org/10.32836/2521-6473-2019-3-14-23

\author{
А. В. Бойко, здобувач кафедри \\ адміністративного та митного права \\ Університету митної справи та фрінансів
}

\title{
АДМІНІСТРАТИВНИЙ ПРОЦЕС ТА АДМІНІСТРАТИВНА ПРОЦЕДУРА: ЗМІСТ КАТЕГОРІЙ ТА ЇХ СПІВВІДНОШЕННЯ (ОКРЕМІ АСПЕКТИ ДИСКУСЇ̈)
}

Наголошено, щз конструктивна наукова дискусія забезпечує постійний невпинний розвиток адміністративно-правової доктрини, дає змогу одержати нові (часом принцииово нові) результати та збагатити теоретичну основу, поглибити ії. В межах иієї публікаиії на підставі узагальненого аналізу доктринальних джерел автором буде здійснено спробу визначити зміст категорії «адміністративний процес» та висловлено власну точку зору з приводу співвідношення иієё категорії з іншим поняттям «адміністративна процедура».

Проаналізовано наукові напрями дослідження сутності адміністративного процесу (у тому числі широка конщепція, управлінська конщепџія, юрисдикиійна конщепщія, «судочиньска»). Висловлено та аргументовано думку про хибність широкого розуміння адміністративного процесу та сформованих на його базі інших наукових підходів.

Підкреслено, що викладена точка зору про суть адміністративного процесу, а точніше погляд на ті правовідносини, що регулюються адміністративно-прочесуальними нормами чи адміністративно-процедурними, вірно уособлює правильне (з точки зору логіки) співвідношення процесу та процедури. Доведено, щз иі дві категорії (адміністративний прочес та адміністративна прочедура) пояснюють абсолютно різні механізми, щзо мають неоднакові завдання та призначення. Зокрема, адміністративний процес - судовий порядок вирішення деяких публічно-правових спорів, а адміністративна процедура (як узагальнена назва) охоплює всю діяльність публічної адміністрачії - від реалізаиії повноважень щодо надання адміністративних послуг до застосування заходів адміністративного примусу і так далі. Іншими словами, адміністративна процедура пов 'язана лише із механізмами реалізації публічною адміністрацією своїх інструментів діяльності.

Ключові слова: адміністративний процес, адміністративна процееура, концепція, категорія, розуміння.

A. V. Boiko. Administrative process and administrative procedure: contents of the categories and their relations (some aspects of discussion)

It is emphasized that a constructive scientific discussion provides for continuous continuous development of administrative-legal doctrine, allows to obtain new (sometimes fundamentally new) results and to enrich the theoretical basis, to deepen it. Within the framework of this publication, on the basis of a generalized analysis of doctrinal sources, the author will attempt to determine the content of the category "administrative process" and express his own point of view regarding the relation of this category to another term - "administrative procedure".

The scientific directions of the study of the essence of the administrative process (including the broad concept, the management concept, the jurisdictional concept, the "sudichinskaya") are analyzed. The opinion about the fallacy of a broad understanding of the administrative process and other scientific approaches formed on its basis is expressed and substantiated.

It is emphasized that the point of view of the essence of the administrative process, and more precisely the view of those relationships that are governed by administrative procedural rules or administrative and procedural, correctly represents the correct (in terms of logic) the relationship between process and procedure. It is proved that these two categories (administrative process and administrative procedure) explain completely different mechanisms that have different tasks and purposes. In particular, the administrative process is a judi-

(C) А. В. Бойко, 2019 
cial procedure for resolving certain public-law disputes, and the administrative procedure (as a generic name) covers all activities of the public administration (from the exercise of powers to provide administrative services to the application of administrative enforcement measures, etc.). In other words, the administrative procedure is only related to the mechanisms for the public administration to implement its tools of activity.

Key words: administrative process, administrative procedure, concept, category, understanding.

Постановка проблеми. Структурна складність адміністративного права як галузі права багато у чому пояснюється доволі заплутаною та неоднозначно сформульованою в деяких наукових та навчальних джерелах галузевою категоріальною базою. Як відомо, численні суперечки в колі вчених-адміністративістів точаться з приводу розуміння та змістовного наповнення таких фундаментальних понять, як «система адміністративного права», «адміністративний процес», «адміністративна процедура», «публічний інтерес», «публічне адміністрування», «інструменти публічної адміністрації» тощо.

3 одного боку, своєрідне завершення пошуку «спільного знаменника» 3 означених дискусійних питань дало б змогу не тільки уніфікувати уявлення про адміністративне право як галузь права, спрямовану на забезпечення реалізації прав і свобод приватної особи в публічній сфері, але й значно спростило б його розуміння не тільки правозастосовувачами та публічними службовцями, а й студентами - майбутніми правниками. 3 іншого боку, конструктивна наукова дискусія, у тому числі й із вказаних аспектів, забезпечує постійний невпинний розвиток адміністративно-правової доктрини, дає змогу одержати нові (часом принципово нові) результати та збагатити теоретичну основу, поглибити ііі. Зокрема, в межах цієї публікації на підставі узагальненого аналізу доктринальних джерел автором буде здійснено спробу визначити зміст категорії «адміністративний процес» та висловлено власну точку зору з приводу співвідношення цієї категорії з іншим поняттям - «адміністративна процедура».

Наукові напрями дослідження сутності адміністративного процесу.

Сформована ще за радянський час так звана широка концепція розуміння адміністративного процесу одержала серед сучасної спільноти вчених-адміністративістів найбільшу підтримку. Доволі цілісну картину основних ідей адептів вказаного уявлення про адміністративний процес представив у своїй дисертації на здобуття наукового ступеня доктора юридичних наук О.В. Муза.

Так, вчений пише, що згідно 3 «широкою» концепцією адміністративного процесу (О.М. Бандурка, Д.М. Бахрах, Ю.П. Битяк, В.В Богуцький, В.М. Гаращук, С.3. Женетль, О.В. Когут, В.К. Колпаков, О.В. Кузьменко, Н.Р. Нижник, І.В. Панова, АО. Селіванов, В.Д. Сорокін, С.Г. Стеценко, Г.І. Петров, Ю.О. Тихомиров. М.М. Тищенко та інших) його слід розуміти як:

- процес виконавчої та розпорядчої діяльності органів державного управління;

- як адміністративно-правотворчий процес (діяльність 3 прийняття нормативних адміністративних актів);

- адміністративно-правонаділяючий (оперативно-розпорядчий) процес (діяльність з прийняття та виконання оперативно-розпорядчих, правонаділяючих та інших правозастосовних актів, спрямованих на організацію виконання законів та інших правових актів) та адміністративно-юрисдикційний процес (вирішення суперечок між різними суб'єктами, застосування заходів адміністративного та дисциплінарного примусу);

- урегульована адміністративно-процесуальними нормами діяльність публічної адміністрації, спрямована на реалізацію норм відповідних матеріальних галузей права під час розгляду і вирішення індивідуально-конкретних справ;

- діяльність зі створення (зміни, призупинення, зупинення) підзаконних нормативних актів виконавчих органів публічної влади - адміністративно-нормотворчий процес; діяль- 
ність вказаних органів публічного управління з реалізації прав та обов'язків індивідуальних та колективних суб'єктів у сфері управління, яка здійснюється в адміністративній формі адміністративно-правонаділяючий процес; правозастосовча діяльність юрисдикційного правоохоронного характеру, застосування державного правового примусу в адміністративно-процесуальній формі - адміністративно-юрисдикційний процес;

- встановлений законом порядок розгляду та вирішення індивідуальних справ, що виникають у сфері державного управління, судами (загальної юрисдикції чи спеціально створеними) або спеціально уповноваженими на те органами (посадовими особами), провадження у справах про адміністративні правопорушення та застосування до правопорушників адміністративних стягнень;

- вид юридичного процесу, який регламентує порядок розгляду і розв’язання конкретних адміністративних справ як діяльність, що грунтується на нормах адміністративно-процесуального права, виконавчих органів держави, їхніх посадових осіб, а також інших уповноважених на те суб'єктів щодо реалізації норм матеріального адміністративного права, а у низці випадків і матеріальних норм інших галузей права;

- врегульована нормами адміністративно-процесуального права діяльність органів публічної адміністрації та деяких інших владних суб'єктів, спрямована на розгляд та розв'язання адміністративних справ;

- владна діяльність відповідних органів (посадових осіб) виконавчої влади та у визначених законодавством випадках органів місцевого самоврядування й органів правосуддя, яка спрямована на розгляд та розв'язання адміністративних справ шляхом реалізації та захисту матеріальних норм не лише адміністративного, а й інших галузей права, і яка характеризується зазвичай швидкістю й економічністю;

- закріплена у нормах права послідовність та порядок дій органів державної влади, їхніх посадових осіб, необхідних для здійснення нормативно встановлених завдань та функцій.

При цьому сам О.В. Муза, хоч і визнає у такому підході певні недоліки, проте стверджує, що «широка» концепція адміністративного процесу є найбільш визнаним доктринальним підходом у науці адміністративного права, оскільки їі представники висвітлюють сутність адміністративного процесу через різні сфери реалізації адміністративного матеріального правовідношення за допомогою процесуально-правових засобів. «Поділяючи зміст «широкої» концепції адміністративного процесу, - зазначає вчений, - можна уникнути наукових неточностей щодо характеристики окремих видів процесуальних правовідносин в адміністративному праві» [1, с. 12-14].

Про колосальне визнання вказаного підходу науковою спільнотою свідчить і той факт, що основні його тези підтримуються відомими та авторитетними сучасними вченими-адміністративістами. Зокрема, В.К. Колпаков підкреслює, «що саме широке розуміння адміністративного процесу відповідає сучасним нормам розвитку правової науки і втіленим у Концепції адміністративної реформи принципам трансформації державного управління в дієвий інструмент реалізації громадянами своїх прав і свобод, інструмент захисту людини від неправомірних дій і адміністративних актів з боку органів управління і їхніх службовців» [2, с. 363], a А.О. Селіванов вважає, що адміністративний процес включає сукупність послідовно здійснюваних стадій належної поведінки суб' єктів - учасників адміністративних правовідносин, за яких між ними розподіляються права і обов'язки стосовно нормативності факту як особливої властивості дійсності. Матеріальне адміністративне право, як підкреслює дослідник, відображає прагнення сторін досягти встановленої законом мети, що виступає засобом пізнання факту і становить суть процесу. Цим висновком, як вважає А.О. Селіванов, створюється передумова для широкого розуміння адміністративного процесу, що дозволяє уникнути надмір- 
ного фіксування термінів правової науки, а в результаті не допустити звуження трактування процесу у вузькому юрисдикційному його розумінні [3, с. 14-15].

Вчений-адміністративіст при цьому наводить досить розгорнуту структуру такого процесу, а саме: «розгляд справ, пов'язаних з публічно-правовими відносинами; адміністративне провадження; управлінські процедури; процесуальні правила, обов'язкові для відносин органів виконавчої влади, місцевого самоврядування (посадових осіб) з іншими юридичними особами та громадянами; порядок розв'язання спірних питань в управлінській діяльності та інші різновиди правозастосовної та правовиконавчої діяльності» [3, с. 6].

С.Г. Стеценко своєю чергою пропонує дещо звужений варіант структури адміністративного процесу з такими трьома складниками: 1) адміністративно-судовий процес, у межах якого здійснюється розгляд публічно-правових спорів в адміністративних судах; 2) адміністративно-управлінський процес, у межах якого здійснюється виконавчо-розпорядча діяльність органів публічної адміністрації; 3) адміністративно-юрисдикційний процес, у межах якого здійснюється розгляд справ про адміністративні правопорушення та застосування заходів адміністративного примусу [4, с. 44]. Підтримує саму таку «тріаду» й О.В. Муза, який дещо інакше називає вказані складники [1, с. 23] .

Натомість С.Т. Гончарук обмежує зміст вказаної категорії, зазначаючи, що адміністративний процес логічно визначати як урегульовану адміністративно-процесуальними нормами діяльність уповноважених на те суб'єктів щодо розгляду і вирішення індивідуально-конкретних адміністративних справ, які формуються в ході реалізації матеріальних норм адміністративного та деяких інших галузей права у сфері публічного управління та адміністративного судочинства. Іншими словами, стосовно сутності і змісту адміністративного процесу, на думку С.Т. Гончарука, доцільно поєднати у цій субстанції і управлінський, і судовий іiі складники, взявши за основу їі управлінсько-судову концепцію [5, с. 63].

Натомість О.В. Кузьменко підкреслює складну структуру вказаного різновиду юридичного процесу і можливість його розгляду як за вертикаллю, так і за горизонталлю. Щодо останнього (розгляд за горизонталлю), то вчена пропонує розглядати його як сукупність проваджень, як «системні утворення, комплекси взаємозалежних і взаємозумовлених процесуальних дій». В системі адміністративного процесу, на ії думку, доцільно акцентувати увагу на адміністративно-процедурних, адміністративно-деліктних та адміністративно-судочинських видах проваджень [6, с. 40]. В аспекті вертикальної структури адміністративного процесу акцент уваги зосереджується на співвідношенні адміністративного процесу та адміністративного провадження як загального і часткового, цілого і частини, наявності нерозривних взаємозумовлених і системоутворюючих зв'язків і відносин між ними. При цьому кожне провадження своєю чергою складається із стадій, а вони - 3 етапів, i, нарешті, 3 процесуальних дій [6, с. 42-44].

Фактично на базі цього підходу було сформульовано більш деталізовану його «гілку» (відгалуження) - управлінську концепцію адміністративного права. Її основні положення свого часу окреслив В.Д. Сорокін, а саме: а) адміністративний процес - це юридична форма реалізації виконавчої влади (він має яскраво виражену юридично управлінську природу); б) адміністративний процес динамічний, отже, він реалізується органами виконавчої влади всіх рівнів, а у випадках, передбачених законом, й іншими суб'єктами (наприклад, суддями); в) адміністративний процес - діяльність не тільки державно-владна, а й юридична; г) адміністративний процес об'єктивно потребує «власного» регулювання, що забезпечується за допомогою адміністративно-процесуальних норм; він забезпечує реалізацію й ряду інших галузей матеріального права - цивільного, фінансового, трудового, сімейного, земельного тощо; д) адміністративний процес - це не тільки врегульований правом порядок здійснення певних процедур

ISSN 2521-6473

Правова позиція, № 3 (24), 2019 
виконавчої влади 3 правового вирішення широкого спектра індивідуально-конкретних справ у сфері державного управління, а й така діяльність, під час реалізації якої виникають численні правові відносини, які регулюються адміністративно-процесуальними нормами й набувають у зв'язку з цим характеру адміністративно-процесуальних відносин [7, с. 197-203; 8, с. 13-14].

Відрізняється від вказаного підходу так звана юрисдикційна концепція адміністративного процесу, що набула обриси наукової течії у працях Н.Г. Саліщевої та ії послідовників ще у 60-80 pp. XX століття, які виробили певні наукові постулати, що й сформували своєрідну основу «юрисдикційної концепції», а саме: а) адміністративний процес представляє собою особливий вид виконавчої та розпорядчої діяльності, пов'язаний із можливістю реалізувати в примусовому порядку положення відповідних адміністративно-правових актів, які визначають права і обов'язки учасників майбутнього адміністративного правовідношення; б) ототожнення понять «адміністративного процесу», «цивільного процесу», «кримінального процесу» (процес $є$ способом забезпечення обов'язковості норм матеріального права і застосування заходів впливу по відношенню до осіб, які порушують правові норми); в) адміністративне провадження розглядається як явище набагато ширше, ніж адміністративний процес; г) адміністративно-процесуальні норми покликані регулювати лише розгляд спорів та застосування заходів примусу державними органами, решту ж відносин регулюють матеріальні норми [7, с. 186-190; 9, с. 19-24, 8, с. 13].

Вона, як і управлінська концепція, також активно підтримується деякими сучасними вітчизняними вченими-адміністративістами. Так, наприклад, О.І. Миколенко, розвиваючи ідеї юрисдикційної концепції, відзначає, що адміністративний процес не повинен обмежуватись тільки сферами діяльності адміністративних судів щодо розгляду публічних спорів в порядку, передбаченому КАС України, та діяльності органів адміністративної юрисдикції щодо розгляду справ про адміністративні правопорушення в порядку, передбаченому КУПАП, як це $\epsilon$ сьогодні. Адміністративно-процесуального забезпечення, як наголошує вчений, потребують й дисциплінарні провадження з адміністративних справ, що передбачені дисциплінарними статутами та спеціальними положеннями про дисципліну; виконавче провадження та контрольна діяльність адміністративних органів відносно приватних осіб [10, с. 18]. На його думку, адміністративний процес - це урегульована адміністративно-процесуальними нормами послідовність дій суб'єктів правозастосовчої діяльності, спрямованих на вирішення адміністративної справи та структурованих відповідними процесуальними відносинами [11, с. 314-315].

Останніми роками на шпальтах юридичної літератури дедалі частіше окремі представники адміністративно-правової науки, як видається у розвиток юрисдикційної концепції, почали звертати увагу на відособленість від матеріальних та процедурних норм адміністративного права тих норм, що регулюють вирішення спорів в порядку адміністративного судочинства. Іншими словами, вчені-адміністративісти (наприклад, В.М. Бевзенко, Р.С. Мельник, I.О. Картузова, А.Т. Комзюк, П.С. Лютіков та інші) пропонують розглядати «адміністративний процес» як категорію, що вживається лише в межах діяльності адміністративного суду.

Наприклад, В.М. Бевзенко пропонує визнати серед галузей права адміністративно-правового циклу й адміністративно-процесуального змісту такі: адміністративне (матеріальне право) - галузь права, призначення якої має полягати у врегулюванні здійснення, сприяння здійсненню фізичними і юридичними особами у публічних правовідносинах з публічною адміністрацією їх прав, законних інтересів у різних сферах суспільно-державного життя. При цьому, на думку В.М. Бевзенка, адміністративна процедура - це насамперед інститут адміністративного (матеріального) права, загальний зміст та призначення якого описується в загальній частині цієї галузі права [12, с. 58]; адміністративне процесуальне право - галузь права, яка описує послідовність і зміст захисту суб'єктивних прав, свобод, законних інтере- 
сів публічного змісту в судовому порядку; це - галузь права, яка визначає юрисдикцію, повноваження адміністративних судів щодо розгляду адміністративних справ, зміст звернення до адміністративних судів та здійснення адміністративного судочинства (ч. 1 ст. 1 Кодексу адміністративного судочинства України) [13; 12, с. 58]. Що стосується так званого деліктного складника, то як слушно зазначає В.М. Бевзенко, він охоплюється межами саме адміністративної процедури [13, с. 60].

Негативне ставлення щодо одночасного існування судового і так званого управлінського адміністративного процесу висловлює і В.П. Тимощук. На думку вченого, нераціональним $\epsilon$ використання категорії «адміністративний процес» у так званому широкому значенні, оскільки не коректно вживати один термін на позначення принципово відмінних явищ - адміністративного судочинства і діяльності адміністративних органів [14, с. 18].

Своєю чергою більш жорстко 3 приводу явної хибності широкого розуміння адміністративного процесу висловлюється Р.С. Мельник. Вчений наголошує, що в обгрунтування так званої «широкої» концепції адміністративного процесу її авторами покладено винятково висновки (наукові концепції), сформульовані або за радянських часів, або представниками «неорадянської» школи адміністративного права [15, с. 289]. Як зазначає Р.С. Мельник, інститут адміністративної юстиції, пройшовши досить довгий трансформаційний шлях у межах системи вітчизняного адміністративного права, також набув ознак цілісної галузі права, які дозволяють йому зайняти самостійне місце у системі національного права [15, с. 293].

Із сказаним не погоджується О.I. Миколенко, який зауважує, що «...якщо адміністративне судочинство виділиться в самостійну галузь права, то це буде остаточним ударом по класифікації норм права на матеріальні і процесуальні, оскільки в рамках адміністративного права залишиться величезний масив процесуальних норм [16, с. 92].

Враховуючи обрану в цій роботі тематику та важливість відповіді на поставлені питання, вважаємо за необхідне також долучитися до дискусії щодо змісту категорії «адміністративний процес». По-перше, доволі значна кількість вчених вважають, що процес та процедура співвідносяться як ціле та частина, що, на нашу думку, є дещо штучно сгенерованою науковою гіпотезою. Звернемося до етимології та тлумачення вказаних слів. Відповідно до тлумачного словника сучасної української мови слово «процес» (лат. processus - рух) означає: 1) послідовну зміну станів або явищ, що відбуваються закономірним порядком; хід розвитку чого-небудь. Сукупність послідовних дій, засобів, спрямованих на досягнення певного наслідку; 2) активний розвиток хвороби; 3) розгляд судової справи; сама судова справа. Визначений законом порядок діяльності слідчих і судових органів під час розгляду судових справ певного роду $[17$, с. 1179]. «Процедура» (від от лат. procedo - просуваюсь) - 1) офіційно встановлений чи узвичаєний порядок здійснення, виконання або оформлення чого-небудь. Ряд яких-небудь дій, хід виконання чого-небудь (розмовн.); 2) у програмуванні - блок з формальними параметрами або без них, виконання якого відбувається після приведення його до стану готовності до виконання; 3) лікувальний захід, переважно призначений лікарем [17, с. 1179].

Спільним між вказаними категоріями є загалом тільки те, що ними позначається певна сукупність дій, спрямована на досягнення певного результату чи наслідку. Однак з цього зовсім не випливає, що процедура є складовою частиною процесу, або те, що процес є більш широкою категорією, ніж процедура. Як мінімум етимологічних чи філологічних передумов для цього немає. До речі, вказана спільна їх ознака ставить під сумнів й іншу (досить суперечливу) думку про те, що ці поняття різняться між собою як статичне та динамічне. Зокрема Т.О. Гуржій та О.В. Кузьменко пишуть, що якщо явище процесу - це передусім динаміка, безперервний рух, виражений у послідовних переходах від одного стану до іншого, то процедура являє собою ніщо інше, як дискретність (роздільність, переривистість) такого руху, є яви-

ISSN 2521-6473

Правова позиція, № 3 (24), 2019 
щем, наділеним часовою динамікою [18, с. 137]. На нашу думку, немає жодних підстав вважати процедуру (тим більше адміністративну) статичним явищем, оскільки вона відбувається в певному порядку, алгоритмі, що передбачає перехід від однієї стадії до іншої, а внаслідок досягнення кінцевого етапу зазвичай відбувається ще й трансформація чи модифікація статусу учасників відповідних правовідносин, що підтверджує «рухливість» відповідних правовідносин. Іншими словами, і процес, і процедура - явища динамічні. До речі, так само вважає й О.І. Миколенко, який не підтримує вказаних ідей Т.О. Гуржія та О.В. Кузьменко [11, с. 240].

По-друге, зазначимо, що у вищенаведеному аспекті дискусії наша точка зору повною мірою співпадає з думками Р.С. Мельника, який абсолютно точно підкреслює, що розуміння концепції адміністративного процесу в європейських державах зовсім інакше, ніж в радянській та пострадянській правовій літературі. «Іїі особливість, - як пише вчений, - порівняно з радянською теорією полягала у тому, що адміністративно-процесуальне право, тобто сукупність норм, які регламентували порядок розгляду публічних спорів в адміністративних судах, розглядалося винятково через призму самостійної галузі публічного права, яка існувала та розвивалася паралельно з галуззю адміністративного права. < ..> Наприклад, у німецькій теорії адміністративного права виникло декілька термінів, за допомогою яких вчені почали відмежовувати принципово різні види діяльності відповідних органів держави. Так, для позначення діяльності органів виконавчої влади, а також органів місцевого самоврядування, пов'язаної із застосуванням матеріальних норм публічного, насамперед адміністративного права, у правовий обіг було введено поняття «адміністративна процедура» (Verwaltungsverfahren). Натомість процесуальна діяльність адміністративних судів визначалася через дефініцію «адміністративний процес» (Verwaltungsprozeß)» [15, с. 290].

По-третє (яке, тісно пов'язане із попереднім доводом), на нашу думку, не зовсім коректне розуміння адміністративного процесу як всеохоплюючого явища в тому числі пояснюється й історичними традиціями, що сформувалися у Радянському Союзі щодо нормотворення, здійснення державного управління та вирішення публічних спорів зазвичай в позасудовому порядку. Зокрема, як слушно у цьому контексті зазначається в новітній юридичній літературі, зміст радянської концепції адміністративного процесу полягає у тому, що він «...є категорією, у межах якої знаходить прояв процесуальна діяльність, пов'язана із застосуванням матеріальних норм адміністративного права, причому незалежно від того, хто їх застосовує - суб'єкти публічної адміністрації або адміністративні суди. Подібне ставлення до адміністративного процесу сформувалося у радянській адміністративно-правовій науці у другій половині $\mathrm{XX}$ ст., тобто у період активного розвитку суто радянського праворозуміння та формування суто радянського адміністративного права, якому на ті часи вдалося вже повністю позбутися від нашарувань дореволюційних та зарубіжних правових концепцій. Переломним моментом у цьому плані, як відомо, стала Перша Всесоюзна нарада з питань радянської держави та права, матеріали якої й заклали підвалини теорії радянського адміністративного права. Зокрема, було висловлено твердження про безконфліктний характер адміністративно-правових відносин, що виникали між посадовими особами та громадянами» [19, с. 137; 15, с. 288].

По-четверте, якщо аналізувати (за логікою широкого розуміння) зміст адміністративних правовідносин, які виникають у сфері публічного адміністрування, то вони фактично майже усі регулюються переважно процесуальними нормами права. За таких обставин постають питання до тих представників вказаної концепції, які наполягають на тому, що адміністративно-процесуальне право ${ }^{1} \epsilon$ самостійною галуззю права. Який же у такому разі залишається

\footnotetext{
${ }_{1}^{1}$ Як система юридичних норм, якими регламентуються державно-владні організуючі суспільні відносини, що виникають у зв'язку з реалізацією адміністративно-процесуальної форми по застосуванню норм відповідних матеріальних галузей права [20, с. 168].
} 
відсоток норм власне адміністративного права, «задіяних» у регулюванні відносин, що виникають у сфері публічного адміністрування? Чи не втрачає у такому випадку адміністративне право значну (якщо не всю) частину свого предмета, якщо нормами адміністративно-процесуального права «обслуговуються» так звані контрольні, реєстраційні, атестаційні, дозвільні провадження, провадження за заявами та пропозиціями громадян, провадження із застосування адміністративно-попереджувальних заходів, провадження із застосування заходів адміністративного припинення, провадження у справах про адміністративні правопорушення, провадження по скаргах осіб і так далі?²

Вбачається, що відповідь на ці питання лежить на поверхні, а вказані норми, на нашу думку, не є процесуальними по своїй суті. Іншими словами, досить значна кількість вчених-адміністративістів бачать процес там, де його нема. Адміністративно-процесуальними відносинами, таким чином, є лише ті, в яких приймає участь суд як лідируючий суб'єкт в адміністративному судочинстві, в порядку якого й вирішуються публічно-правові спори. Звісно, у такому разі постає інше, цілком логічне питання - а що ж тоді робити із провадженням у справах про адміністративні правопорушення, які розглядаються судом? Здається, що попереднім висновком ми «загнали себе у глухий кут» цієї дискусії? Однак це не так, тому що відповідь на вказане питання лежить у площині іншої дискусії - про зміст деліктного складника адміністративного права. Ми ведемо мову про те, що для правильного та логічного розуміння як системи адміністративного права, так і системи адміністративного процесу важливо усвідомити, що необхідно чітко та правильно визначити зміст та межі адміністративно-деліктних норм. Зокрема, ми переконані у тому, що наразі доволі значна кількість складів адміністративних проступків, що міститься у Кодексі України про адміністративні правопорушення, не мають безпосереднього відношення до адміністративного права як галузі, що фактично регулює правовідносини, які виникають у сфері публічного адміністрування.

У нашому розумінні, адміністративний делікт - це дія або бездіяльність, напряму пов'язана із порушенням правил та стандартів, встановлених публічною адміністрацією, в якому відсутні ознаки кримінального проступку або кримінального злочину․․ Наприклад, такими правилами є: правила дорожнього руху, різноманітні правила експлуатації усіх видів транспорту, встановлені стандарти охорони праці, екологічні нормативи, правила ядерної та радіаційної безпеки, стандарти та правила будівництва тощо.

При цьому єдиним юрисдикційними суб'єктом, тобто уповноваженою на застосування адміністративних стягнень особою, має бути той орган публічної адміністрації, який це правило встановив. Порядок притягнення має визначатись Законом України «Про адміністративну процедуру», який у тому числі має передбачити й адміністративну процедуру оскарження рішення про накладення адміністративного стягнення. При цьому це не виключає права особи, яка була притягнута до відповідальності, оскаржити вказане рішення в порядку адміністративного судочинства. Отже, порядок притягнення до адміністративної відповідальності визначається адміністративно-процедурними нормами, а судова процедура оскарження рішення суб'єкта публічної адміністрації про накладення адміністративного стягнення регулюється винятково Кодексом адміністративного судочинства України.

Висновки 3 дослідження і перспективи подальших розвідок у цьому напрямі. Таке уявлення про суть адміністративного процесу, а точніше погляд на ті правовідносини, що

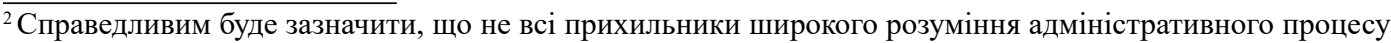
ствердно говорять про галузеву відособленість його норм, а відповідно, систематизують їх сукупність лише на рівні підгалузі адміністративного права.

3 Звісно, остаточну крапку у вирішенні цього питання, на нашу думку, має поставити остаточне запровадження інституту кримінального проступку, який, у нашому розумінні, має увібрати у себе й частину тих адміністративних правопорушень, що не мають відношення до сфери адміністративного права.
}

ISSN 2521-6473

Правова позиція, № 3 (24), 2019 
регулюються адміністративно-процесуальними нормами чи адміністративно-процедурними, вірно уособлює правильне (з точки зору логіки) співвідношення процесу та процедури, яка своєю чергою є визначеним законодавством порядком здійснення адміністративного провадження як сукупності процедурних дій, послідовно вчинених адміністративним органом, і прийнятих процедурних рішень з розгляду та вирішення адміністративної справи, що завершується прийняттям і в необхідних випадках виконанням прийнятого адміністративного акта [21]. Іншими словами, адміністративна процедура пов'язана лише із механізмами реалізації публічною адміністрацією своїх інструментів діяльності і тому цілком логічним стає висновок про те, що ці дві категорії (адміністративний процес та адміністративна процедура) пояснюють абсолютно різні механізми, що мають неоднакові завдання та призначення. Так, адміністративний процес - судовий порядок вирішення деяких публічно-правових спорів, а адміністративна процедура (як узагальнена назва) охоплює всю діяльність публічної адміністрації - від реалізації повноважень щодо надання адміністративних послуг до застосування заходів адміністративного примусу і так далі.

\section{Список використаних джерел:}

1. Муза О.В. Адміністративно-процесуальні правовідносини в Україні : монографія. Київ, «Четверта хвиля, 2015». 320 с.

2. Колпаков В.К. Адміністративно-деліктний правовий феномен / Національна академія внутрішніх справ України / Валерій Костянтинович Колпаков. Київ : Юрінком Інтер, 2004. $528 \mathrm{c}$.

3. Селіванов А.О. Адміністративний процес в Україні: реальність і перспективи розвитку правових доктрин. Київ : Видавничий Дім «Ін Юре», 2000. 68 с.

4. Стеценко С. Сутність адміністративного процесу: теоретичний погляд. Право України. 2011. № 4. С. 39-46.

5. Гончарук С.Т. Адміністративний процес у сучасній вітчизняній правовій доктрині. Юридичний вісник. 2014. № 4 (33). С. 60-64.

6. Кузьменко О.В. Курс адміністративного процесу : Навчальний посібник. Київ : Юрінком Інтер, 2012. 208 c.

7. Сорокин В.Д. Административно-процессуальное право : учебник. Санкт-Петербург : Изд-во Р. Асланова «Юридический центр «Пресс», 2008. 571 с.

8. Кукурудз Р.О. Апеляція в адміністративно-юрисдикційному процесі: питання теорії та практики : дис. ... на здобуття наук. ступеня кандидата юрид. наук 12.00.07. Запоріжжя, 2010. 213 c.

9. Сорокин В.Д. Административный процесс и административно-процессуальное право. Санкт-Петербург : Изд-во Юридического института, 2002. 474 с.

10. Миколенко О.I. Місце адміністративного процедурного права в системі юридичних знань та системі права України : автореф. дис...на здобуття наук. ступеня доктора юрид. наук 12.00.07 «Адміністративне право і процес; фінансове право; інформаційне право». Запоріжжя, $2010.44 \mathrm{c}$

11. Миколенко О.І. Місце адміністративного процедурного права в системі юридичних знань та системі права України : докт. юрид. наук : 12.00.07. Одеса, 2010. 444 с.

12. Бевзенко В.М. Деякі теоретичні міркування щодо адміністративних процесуальних і процедурних категорій у вітчизняній адміністративно-правовій та адміністративно-процесуальній науці. Вісник Вищего адміністративного суду України. 2011. № 3. С. 56-62.

13. Кодекс адміністративного судочинства України : Закон України від 06 липня 2005 року № 2747-IV. Офіційний вісник України. 2005. № 32. Ст. 11. 
14. Тимощук В.П. Адміністративна процедура та адміністративні послуги. Зарубіжний досвід і пропозиції для України. Київ : Факт, 2003. 496 с.

15. Мельник Р.С. Система адміністративного права України : дис. ... докт. юрид. наук : 12.00.07. Харків, 2010. 415 с.

16. Миколенко О.І. Теорія адміністративного процедурного права : монографія. Харків, «Одиссей» 2010.336 c.

17. Великий тлумачний словник сучасної української мови / уклад. і голова ред. В.Т. Бусел. Київ ; Ірпінь : ВТФ «Перун», 2001. 1440 с.

18. Кузьменко О.В., Гуржій Т.О. Адміністративно-процесуальне право України : підручник. Київ : Атіка, 2007. 416 с.

19. Егоров П.Ю. Становление советского административного права (1917-1940). Ульяновск : ИПК «Ульяновский Дом печати», 2006. 160 с.

20. Кузьменко О.В. Процесуальні категорії адміністративного права : монографія. Львів : «Національна академія внутрішніх справ», 2004. 232 с.

21. Про адміністративну процедуру: Проект Закону № 9456 від 28.12.2018. URL: http://w1.c1.rada.gov.ua/pls/zweb2/webproc4_1?pf3511=65307. 
УДК 342.9

DOI https://doi.org/10.32836/2521-6473-2019-3-24-30

\author{
І. Л. Желтобрюх, кандидат юридичних \\ наук, здобувач кафедри адміністративного \\ та господарського права \\ Запорізького національного університету
}

\title{
АДМІНІСТРАТИВНИЙ ПРОЦЕС У СУЧАСНІЙ ДОКТРИНІ АДМІНІСТРАТИВНОГО ПРАВА ЯК СФЕРА ОБ'ЄКТИВІЗАЦІї СТАТУСУ СТОРІН СУДОЧИНСТВА
}

У роботі розкрито загальні тендениії розвитку наукової думки про адміністративний процес, починаючи з 1991 року. Були виділені та охарактеризовані етапи розвитку наукової думки про адміністративний процес. Зазначається, щуо вивчення і знання історії розвитку наукової думки стосовно змісту та сторін адміністративного прочесу дозволяє, по-перше, збагатити багаж знань дослідника про право та правові явища, по-друге, дотримуватись етичних правил у научі, згідно з якими чужі думки та висновки не можна видавати за свої особисті, навіть у тих випадках, коли дослідник, нехтуючи досягненнями минулих поколінь вчених, дійшов висновків самостійно (невігластво в научі), по-третє, попередити дослідника про те, щุо хтось із вчених ичим хибним шляхом вже пройшов, а тому не слід повторювати його помилок. Робиться висновок, що розвиток наукової думки щяодо адміністративного прочесу за часів незалежності України можна поділити на два етапи: 1) до впровадження в Україні адміністративної юстиції (з 1991 по 2004 роки); 2) після впровадження адміністративної юстиції (з 2005 року по сьогодні). Перший етап характеризується тим, щчо велика кількість науковиів продовжувала досліджувати адміністративний прочес за допомогою наукових підходів та інструментарію, що сформувалися ще за часів Радянського Союзу. Разом з тим лише в поодиноких праиях у вигляді прогнозів фрагментарно висвітлювалися питання адміністративно-процесуального статусу сторін. Другий етап характеризується тим, що, по-перше, за окремими науковими напрямами почали досліджуватися проблеми управлінського (неконфліктного, неюрисдикційного), деліктного та судового адміністративного проиесів, по-друге, відбувся поступовий розподіл адміністративних матеріальних, процедурних та процесуальних норм, щз дало можливість адміністративний процес пов'язувати винятково із правосуддям, яке здійснюється адміністративними судами, а адміністративну процедуру - з правотворчою і правозастосовною діяльністю органів публічної адміністрації, по-третє, набули розвитку дослідження адміністративно-прочесуального статусу учасників адміністративного судочинства та дослідження особливостей реалізації процесуальних прав і обов'язків учасниками адміністративного судочинства, в тому числі сторонами адміністративного процесу.

Ключові слова: історія розвитку наукової думки, адміністративний прочес, адміністративне судочинство, сторони адміністративного процесу.

I. L. Zheltobruh. Administrative procedure in the modern doctrine of administrative law as a sphere of objectivization of the status of parties of legal proceedings

The paper describes the general tendencies of the development of scientific opinion about the administrative process since 1991. The stages of development of scientific thought about the administrative process were identified and characterized. It is noted that the study and knowledge of the history of scientific thought regarding the content and sides of the administrative process allows, first, to enrich the luggage of the researcher's knowledge of law and legal phenomena, secondly, to observe ethical rules in science, according to which other people's opinions and conclusions are not can be considered as personal, even in cases where a researcher neglecting the achievements of past generations of scientists concluded independently (ignorance in science), third, to warn the researcher, however, that one of the scientists has already gone through this wrong path, so you should not repeat his mistakes. It is concluded that the development of scientific opinion on the administra-

\section{(C) І. Л. Желтобрюх, 2019}


tive process during the independence of Ukraine can be divided into two stages: 1) before the introduction of administrative justice in Ukraine (1991 to 2004); 2) after the introduction of administrative justice (from 2005 to the present). The first stage was characterized by the fact that a large number of scientists continued to study the administrative process with the help of scientific approaches and tools that had been developed since the Soviet Union. At the same time, the issues of administrative and procedural status of the parties were covered only in solitary works in the form of forecasts and fragmentary. The second stage is characterized by the fact that, firstly, the problems of management (non-conflict, non-jurisdictional), tort and judicial administrative processes began to be investigated in separate scientific directions, and secondly, there was a gradual distribution of administrative material, procedural and procedural possibilities, to associate the process exclusively with justice, which is carried out by administrative courts, and the administrative procedure - with the law-making and enforcement activities of public bodies administrations, thirdly, have acquired the development of research into the administrative and procedural status of participants in administrative proceedings and the study of the peculiarities of the implementation of procedural rights and obligations by participants of administrative proceedings, including the parties to the administrative process.

Key words: history of scientific thought development, administrative process, administrative justice, parties to administrative process.

Постановка проблеми. Вивчення і знання історії розвитку людства та держави застерігає суб'єкта цих знань від повторення помилок, які вже колись кимось були зроблені, вивчення ж і знання історії розвитку наукової думки стосовно змісту та сторін адміністративного процесу дозволяє, по-перше, збагатити багаж знань дослідника про право та правові явища, по-друге, дотримуватись етичних правил у науці, згідно з якими чужі думки та висновки не можна видавати за свої особисті, навіть у тих випадках, коли дослідник, нехтуючи досягненнями минулих поколінь вчених, дійшов висновків самостійно (невігластво в науці), по-третє, попередити дослідника про те, що хтось із вчених цим хибним шляхом вже пройшов, а тому не слід повторювати його помилок.

Іноді неможливо зробити всебічний аналіз правового явища без звернення та врахування думок, які були висловлені науковцями десять, п’ятдесят чи сто років тому. Справжній науковець це людина, яка поєднує в собі системні знання про право в минулому, сьогодні та в майбутньому, а тому звернення до наукової спадщини є атрибутом будь-якої науково-дослідної праці, в тому числі присвяченої проблемам правового статусу сторін в адміністративному процесі.

Зазначене зумовлює необхідність аналізу наукових джерел, які були, по-перше, написані за часи незалежності України, по-друге, присвячені адміністративному процесу та сторонам адміністративного процесу.

Аналіз останніх досліджень і публікацій. Історія розвитку наукової думки в Україні щодо змісту адміністративного процесу, його учасників та адміністративно-процесуальної правосуб'єктності досліджувалася в працях О.М. Бандурки, В.М. Бевзенка, Т.О. Гуржій, Є.Ф. Демського, І.О. Картузової, Т.О. Коломоєць, А.Т. Комзюка, О.В. Кузьменко, Р.С. Мельника, О.І. Миколенка, А.Ю. Осадчого, М.М. Тищенка та багатьох інших вітчизняних науковців.

Разом з тим наявність у сучасній доктрині адміністративного права різних концепцій адміністративного процесу негативно позначається на розвитку адміністративного процесуального законодавства України та визначенні змісту адміністративно-процесуальної правосуб'єктності сторін у адміністративному судочинстві.

Мета статті - розкрити загальні тенденції розвитку наукової думки про адміністративний процес, починаючи 31991 року. Для досягнення поставленої мети варто розв'язати такі завдання:

1. Дослідити загальні тенденції розвитку наукової думки про адміністративний процес, починаючи з 1991 року.

ISSN 2521-6473

Правова позиція, № 3 (24), 2019 
2. Виділити етапи розвитку наукової думки про адміністративний процес та надати їм загальну характеристику.

Виклад основного матеріалу дослідження. 31991 року, а саме з моменту проголошення незалежності України, в нашій державі бурхливо почали розвиватися адміністративні правовідносини організаційного характеру, що позитивно вплинуло на розвиток наукової думки про адміністративний процес. Зокрема, прийнятий у 2005 році КАСУ взагалі став каталізатором досліджень: адміністративного судочинства як однієї із форм юридичного процесу; адміністративної процедури та її співвідношення з адміністративним процесом; процесуальних форм адміністративного судочинства тощо. Цей період можна розділити на два етапи - до та після впровадження в Україні адміністративної юстиції.

Перший етап (з 1991 по 2004 роки) характеризується тим, що велика кількість науковців спробувала продовжити життя багатьох концепцій адміністративного процесу, які виникли в межах радянського адміністративного права, але з урахуванням нових умов як у сфері суспільного життя, так і у сфері державотворення.

В цьому сенсі слід згадати монографію В.М. Протасова «Основи загальноправової процесуальної теорії» [1]. Ця робота була написана на межі розпаду Радянського Союзу (у 1991 році), а тому автор є яскравим представником так званого перехідного періоду, коли вже не було суттєвих обмежень у світоглядній сфері, але мислення продовжувало функціонувати 3 огляду на старі догми і установки, що сформувалися в рамках радянської правової науки. Водночас монографія представляла собою поглиблений аналіз проблем процесуальної теорії і стала своєрідним «букварем» для здобувачів вищої освіти ступеня доктора наук. У своїй монографії В.М. Протасов обгрунтовує точку зору, згідно з якою юридичний процес є різновидом правової процедури. Тобто правовідносини та правові норми вчений за змістом поділяє на дві групи матеріальні (не мають організаційний характер) і процедурні (мають організаційний характер). Серед групи процедурних правовідносин та правових норм В.М. Протасов виділяє відокремлену групу процесуальних правовідносин і норм. Критерієм же такого поділу є правоохоронні відносини та правоохоронна діяльність. Тобто саме правоохоронні відносини та правоохоронна діяльність складають зміст процесуальних відносин та процесуальної діяльності.

По-перше, ми переконані в тому, що вже давно назріла необхідність перегляду в рамках теорії права класифікації правовідносин і правових норм на два види - матеріальні та процесуальні. Вона не відповідає реаліям сьогодення, тим більше, не може використовуватись як методологічна основа в рамках адміністративного права. Водночас ми не можемо погодитись і з підходом, що пропонує В.М. Протасов, адже він теж виділяє два види правовідносин і правових норм, але замість «процесуальних» пропонує виділяти групу «процедурних» правовідносин та правових норм. Впевнені, що є теоретичне підгрунтя для виділення за змістом і цільовим призначенням трьох груп адміністративних правовідносин та правових норм: 1) матеріальні; 2) процедурні; 3) процесуальні. Наприклад, матеріальні норми є статичними нормами, а тому закріплюють систему прав і обов'язків приватних осіб як суб'єктів адміністративного права, повноваження суб'єктів публічної адміністрації, систему органів виконавчої влади тощо. Процедурні норми є організаційними (динамічними) нормами, які закріплюють порядок реалізації суб'єктами публічного адміністрування (органами виконавчої влади та органами місцевого самоврядування) повноважень правотворчого та правозастосовного характеру. Процесуальні норми є організаційними (динамічними) нормами, які закріплюють порядок розгляду адміністративними судами спорів, що виникають в публічно-правовій сфері.

По-друге, «правоохоронні відносини» та «правоохоронна діяльність» не можуть виступати ефективним критерієм розподілу адміністративних процесуальних та процедурних норм. «Правоохоронна діяльність» як термін не має чіткого змістовного визначення. 
О.В. Фатхутдінова в своїй кандидатській дисертації «Теоретико-правові проблеми юридичного процесу» продовжила розвивати концепцію «широкого розуміння юридичного процесу» (2000р.), згідно з якою будь-яка правова процедура є елементом структури юридичного процесу [2]. Такий підхід приводив до того, що серед учасників процесуальних відносин взагалі та адміністративно-процесуальних відносин зокрема можна було виділити не тільки суд, сторони провадження, спеціаліста, експерта тощо, а й, наприклад, юридичну особу, яка звернулася до органів публічної адміністрації для отримання ліцензії на здійснення банківської діяльності.

Обов'язково слід згадати праці М.М. Тищенка, який у 1998 році публікує монографію «Громадянин в адміністративному процесі» [3], а у 2001 році у співавторстві з О.М. Бандуркою - монографію «Адміністративний процес» [4]. М.М. Тищенко є яскравим представником широкого розуміння адміністративного процесу, а тому він поділяв провадження як елемент структури адміністративного процесу на два види - юрисдикційні і неюрисдикційні провадження [4, с. 19-20].

У 2003 році вийшла у світ монографія В.Г. Перепелюка «Адміністративний процес. Загальна частина» [5]. Автор зосередився на обгрунтуванні змісту управлінського процесу, характеристиці його суб'єктів, розкритті особливостей адміністративно-процесуальних відносин та аналізі структури проваджень, що складають адміністративний управлінський процес. В той же час, на нашу думку, праця В.Г. Перепелюка мала і певні недоліки. По-перше, автор уникнув дискусії, яка точилася у той час у науковій літературі стосовно змісту юридичного процесу, одразу ж заявивши про те, що правозастосовна діяльність є тим головним і єдиним критерієм, який дозволяє розмежувати юридичний процес і інші організаційні форми діяльності, що існують в у сфері державного управління [5, с. 5-14], по-друге, до адміністративного управлінського процесу автор відносить провадження у справах про адміністративні правопорушення, про що свідчить розділ, присвячений адміністративному доказуванню та доказам в адміністративному процесі [5, с. 204-228], по-третє, В.Г. Перепелюк є одним із останніх науковців, які в межах адміністративного права продовжували характеризувати адміністративний процес шляхом використання терміну «державне управління» [5, с. 36-82].

У 2003 році була надрукована монографія В.С. Стефанюка «Судовий адміністративний процес» [6]. Автор, визнаючи поділ юридичного процесу на два види - управлінський і судовий, зосередився на характеристиці тоді ще неіснуючого судового адміністративного процесу. Він сам відмічає: «Наукова новизна отриманих результатів полягає в тому, що < ..> подано детальний теоретичний огляд проблем поняття і складників судового адміністративного процесу, грунтуючись на нормативно-правових реаліях України та ряду інших зарубіжних країн з одночасним прогнозуванням розвитку таких реалій» [6, с. 10]. Положення монографії були корисні насамперед для розвитку національного законодавства, адже нагадували текст законопроектів. У науковому ж сенсі монографія не вирішувала жодної теоретичної проблеми та не пропонувала ніяких принципово нових наукових підходів у окресленій сфері. Наприклад, у параграфі 6.1 «Право на звернення до адміністративного суду та порушення справи» В.С. Стефанюк не робить жодного посилання на наукові джерела, а лише посилається на положення проекту Адміністративно-процесуального кодексу, розробленого В.В. Сунцовим і їм самим [6, с. 261-268].

У 2003 році також з'явилися перші комплексні публікації щодо розуміння адміністративної процедури та стосовно ії співвідношення з поняттям «адміністративний процес». Так, В.П. Тимощук у монографії «Адміністративна процедура та адміністративні послуги. Зарубіжний досвід і пропозиції для України», посилаючись на досвід країн світу, доводив необхідність правової регламентації діяльності органів державної влади та місцевого самоуправління з чітким виділенням у цій сфері адміністративних процедур [7]. Ця праця, до речі, стала одним із факторів, які активізували в подальшому діяльність законодавця з питань розробки Адміні-

ISSN 2521-6473

Правова позиція, № 3 (24), 2019 
стративно-процедурного кодексу України. На жаль, і сьогодні це питання в правотворчій сфері остаточно невирішене.

Другий етап (з 2005 року по сьогодні) розвитку наукової думки в незалежній Україні характеризується тим, що, окрім дослідження загальних проблеми адміністративного процесу як виду юридичного процесу, більш предметно почали досліджуватися адміністративне судочинство та процесуальні відносини, що складаються в рамках адміністративного судочинства.

Питанням адміністративного процесу, починаючи з 2005 року, присвячено велику кількість дисертацій, монографій, наукових статей, підручників та навчальних посібників. Не будемо всі їх характеризувати, адже в цьому немає потреби. Хочемо зупинитися лише на знакових працях, які мають високий рівень теоретичного підгрунтя та можуть вплинули на розвиток науки адміністративного процесуального права України.

В цьому сенсі обов'язково слід згадати праці О.В. Кузьменко, а саме іiї докторську дисертацію «Адміністративний процес у парадигмі права» [8] та монографію «Теоретичні засади адміністративного процесу» (2005) [9]. Автор, по-перше, дотримувалась широкого розуміння адміністративного процесу, а саме визначала адміністративний процес як урегульовану адміністративно-процесуальними нормами діяльність уповноважених суб'єктів, спрямовану на реалізацію норм відповідних матеріальних галузей права в ході розгляду і вирішення індивідуально-конкретних справ [8, с. 349], по-друге, розглядала адміністративну процедуру лише як прояв процесуальної форми адміністративного процесу, щоправда, сам термін «процесуальна форма» не використовувався, але використані О.В. Кузьменко підходи до визначення поняття «адміністративна процедура» дають підставу нам самостійно зробити такий висновок [8, с. 181].

Грунтовними працями 3 питань співвідношення понять «адміністративний процес» i «адміністративна процедура» є монографія О.I. Миколенка «Теорія адміністративного процедурного права» [10] та його дисертація «Місце адміністративного процедурного права в системі юридичних знань та системі права України» [11]. Автор, частково продовжуючи думки В.М. Протасова, стверджує, що правовідносини та правові норми за змістом слід поділяти на два види - матеріальні та процедурні. Своєю чергою процедурні правовідносини та правові норми за рівнем правової регламентації О.І. Миколенко поділяє на дві групи - організаційні та процесуальні. Таким чином, автор аргументує думку, згідно з якою адміністративний процес $є$ лише видом більш загального поняття - «адміністративна процедура». Важко погодитись з О.I. Миколенком в тому, що поняттям «адміністративний процес» він намагається охопити не тільки адміністративне судочинство, а й провадження у справах про адміністративні правопорушення, а також дисциплінарне та контрольне провадження, якщо законодавець більш детально їх регламентує [10, с. 171-172]. В такому випадку виходимо з того, що винятково правосуддя має таку форму реалізації, як юридичний процес, тоді як законотворчість та публічне адміністрування реалізуються через чисельні правові процедури, які передбачені чинним законодавством.

Поступово в наукових працях сформувалося три напрями досліджень адміністративного процесу: 1) проблеми управлінського адміністративного процесу (наприклад, Я.Л. Іваненко) [12]; 2) проблеми адміністративно-деліктного процесу (наприклад, О.В. Аніна) [13]; 3) проблеми судового адміністративного процесу (наприклад, В.С. Заяць) [14].

Зрозуміло, що кожен з окреслених вище напрямів характеризував і характеризує адміністративний процес по-своєму. В таких працях суттєво різняться між собою зміст процесуальних відносин, а також ознаки, суб'єкти і структура управлінського, деліктного і судового адміністративних процесів.

У навчально-методичній літературі з адміністративного процесуального права теж спостерігається розлад думок, концепцій і підходів. Наприклад, О.І. Миколенко у навчальному 
посібнику «Адміністративний процес та адміністративна відповідальність в Україні» дає широке трактування адміністративного процесу, пов’язуючи його із правозастосовною діяльністю органів публічної адміністрації стосовно розгляду індивідуально-конкретних справ $[15$, с. 87]. Схожу позицію (з певними відмінностями) висловлює О.В. Кузьменко і Т.О. Гуржій у підручнику «Адміністративно-процесуальне право України» [16] та Е.Ф. Демський у навчальному посібнику «Адміністративне процесуальне право України» [17].

На противагу їм, починаючи з 2007 року, більш наполегливо свою точку зору щодо адміністративного процесу в навчально-методичній літературі почали висловлювати представники вузького (традиційного) розуміння юридичного процесу. Наприклад, А.Т. Комзюк, В.М. Бевзенко та Р.С. Мельник запропонували розмежувати між собою адміністративну процедуру та адміністративний процес залежно від суб'єкта, що здійснює правозастосовну діяльність. У зв’язку з цим правозастосовна діяльність, на їх думку, в адміністративному праві реалізується, по-перше, через адміністративну процедуру (така діяльність реалізується органами виконавчої влади та місцевого самоврядування) і через адміністративний процес (така діяльність реалізується винятково судом в рамках адміністративного судочинства) [18, с. 45-56]. Таку ж концепцію юридичного процесу висвітлюють у своєму підручнику з адміністративного процесуального права України С.В. Ківалов, І.О. Картузова і А.Ю. Осадчий. Вчені підкреслюють: «Як бачимо, адміністративний процес (адміністративне судочинство) виступає як процесуальний складник адміністративної юстиції» [19, с. 13]. До того ж паралельно з цим почали з'являтися в Україні навчально-методичні джерела, які присвячені адміністративному процедурному праву, в яких теж обгрунтовується думка доцільності розмежування адміністративного процесу і процедури залежно від суб'єкта правозастосовної діяльності, наголошуючи на тому, що «адміністративний процес як порядок діяльності адміністративних судів опосередковує здійснення судової влади - правосуддя в адміністративних справах, тоді як адміністративні процедури є порядком здійснення публічного управління» [20, с. 22].

Висновки та перспективи подальших розвідок. За результатами проведеного аналізу можна зробити такі висновки.

Розвиток наукової думки щодо адміністративного процесу за часів незалежності України можна поділити на два етапи: 1) до впровадження в Україні адміністративної юстиції (з 1991 по 2004 роки); 2) після впровадження адміністративної юстиції (з 2005 року по сьогодні).

Перший етап (з 1991 по 2004 роки) характеризується тим, що велика кількість науковців продовжувала досліджувати адміністративний процес за допомогою наукових підходів та інструментарію, які сформувалися ще за часів Радянського Союзу, а тому продовжили розвиватись концепція широкого розуміння адміністративного процесу, юрисдикційна та управлінська концепції адміністративного процесу. Разом з тим лише в поодиноких працях у вигляді прогнозів фрагментарно висвітлювалися питання адміністративно-процесуального статусу сторін.

Другий етап (3 2004 року по сьогодні) характеризується тим, що, по-перше, за окремими науковими напрямами почали досліджуватися проблеми управлінського (неконфліктного, неюрисдикційного), деліктного та судового адміністративного процесів, по-друге, відбувся поступовий розподіл адміністративних матеріальних, процедурних та процесуальних норм, що дало можливість адміністративний процес пов'язувати винятково із правосуддям, яке здійснюється адміністративними судами, а адміністративну процедуру - 3 правотворчою і правозастосовною діяльністю органів публічної адміністрації, по-третє, набули розвитку дослідження адміністративно-процесуального статусу учасників адміністративного судочинства та дослідження особливостей реалізації процесуальних прав і обов'язків учасниками адміністративного судочинства, в тому числі сторонами адміністративного процесу.

ISSN 2521-6473

Правова позиція, № 3 (24), 2019 


\section{Список використаних джерел:}

1. Протасов В.Н. Основы общеправовой процессуальной теории : монографія. Москва : Юридическая литература, 1991. 144 с.

2. Фатхутдінова О.В. Теоретико-правові проблеми юридичного процесу : дис. ... канд. юрид. наук : 12.00.01 / Інститут держави і права ім. В.М. Корецького НАН України. Київ, 2000. $166 \mathrm{c}$.

3. Тищенко Н.М. Гражданин в административном процессе. Харьков : Право, 1998. 192 с.

4. Бандурка О.М., Тищенко М.М. Адміністративний процес : підручник [для вищих навч. закл]. Київ : Літера ЛТД, 2001. 336 с. (рос. мовою).

5. Перепелюк В.Г. Адміністративний процес. Загальна частина : навчальний посібник. Чернівці : Рута, 2003. 367 с.

6. Стефанюк В.С. Судовий адміністративний процес : монографія / В.С. Стефанюк. Харків : Консум, 2003. 464 с.

7. Тимощук В.П. Адміністративна процедура та адміністративні послуги. Зарубіжний досвід і пропозиції для України / [автор-упорядник В.П. Тимощук]. Київ : Факт, 2003. 496 с.

8. Кузьменко О.В. Адміністративний процес у парадигмі права : дис. ... доктор. юрид. наук : 12.00 .07 ; Київський національний університет внутрішніх справ. Київ, 2006. 401 с.

9. Кузьменко О.В. Теоретичні засади адміністративного процесу : монографія. Київ : Атіка, 2005. $352 \mathrm{c}$.

10. Миколенко О.І. Теорія адміністративного процедурного права: монографія. Харків : Бурун Книга, 2010. 336 c.

11. Миколенко О.І. Місце адміністративного процедурного права в системі юридичних знань та системі права України : дис. ...док-ра юрид. наук : 12.00.07. Класичний приватний університет, Запоріжжя, 2011. 444 с.

12. Іваненко Я.Л. Адміністративні неюрисдикційні провадження : дис. ... канд. юрид. наук : 12.00.07. Академія праці і соціальних відносин Федерації професійних спілок України. Київ, 2011. 213 с.

13. Аніна О.В. Іноземці та особи без громадянства в адміністративно-деліктному процесі України: дис. ... канд. юрид. наук: 12.00.07. Державний науково-дослідний інститут МВС України. Київ, 2012. 211 с.

14. Заяць В.С. Правове регулювання участі представника у судовому адміністративному процесі : дис. ... канд. юрид. наук : 12.00.07. Національний університет державної податкової служби України. Ірпінь, 2011. 221 с.

15. Миколенко О.І. Адміністративний процес і адміністративна відповідальність : навчальний посібник. Харків : Одіссей, 2010. 368 с.

16. Кузьменко О.В., Гуржій Т.О. Адміністративно-процесуальне право України : підручник / за заг. ред. О.В. Кузьменко. Київ : Атака, 2007. 416 с.

17. Демський Е.Ф. Адміністративне процесуальне право України : навчальний посібник. Київ : Юрінком Інтер, 2008. 496 с.

18. Комзюк А.Т., Бевзенко В.М., Мельник Р.С. Адміністративний процес України : навчальний посібник. Київ : Прецедент, 2007. 531 с.

19. Ківалов С.В., Картузова І.О., Осадчий А.Ю. Курс адміністративного процесуального права України. Загальна частина : підручник. Одеса : Фенікс, 2014. 342 с.

20. Картузова I.О., Осадчий А.Ю. Адміністративне-процедурне право : навчально-методичний посібник. Одеса : Юридична література, 2008. 288 с. 


\section{А. В. Замрига, кандидат економічних наук,} докторант

Науково-дослідного інституту публічного права

\section{«АДМІНІСТРАТИВНА СЕРВІСНІСТЬ» ЯК ОЗНАКА ДІЯЛЬНОСТІ ПУБЛІЧНОӤ АДМІНІСТРАЦІЇ У СФЕРІ АДМІНІСТРАТИВНО-ПРАВОВОГО ЗАБЕЗПЕЧЕННЯ ГОСПОДАРСЬКОЇ ДІЯЛЬНОСТІ В УКРАЇНІ}

У статті розкрито особливості концепту «держава-сервіс» як перспективного в аспекті розвитку та становлення в Україні. Визначено, що в Україні концепт «держава-сервіс» має перспективу в аспекті розвитку та становлення, однак для изього необхідна політична воля керівної еліти, значна кількість адміністративних реформ та загальна зміна сочіально-політичного клімату в країні, де громадяни довірятимуть владі, матимуть змогу звертатись до ії представників за допомогою, а не як до необтрунтовано привілейованих суб'єктів за «милостинею». Сама ж нинішня кониепиія сервісної діяльності публічної адміністраиії у сфері адміністративно-правового забезпечення господарської діяльності є недосконалою та вимагає перегляду, перетворення та модернізування, зокрема щчодо засад надання публічних послуг. Наголошено, щчо упорядкування послуг є основним напрямом наближення владних органів до пересічного громадянина, в тому числі й суб'єкта господарювання, з метою забезпечення задоволення потреб останнього, а також надасть можливість захисту його прав, свобод і законних інтересів. Виявлено, що нинішня кониепція сервісної діяльності публічної адміністрачії в сфері адміністративно-правового забезпечення господарської діяльності є недосконалою та вимагає перегляду, перетворення та модернізування, зокрема щодо засад надання публічних послуг. Зроблено висновок про необхідність модернізування засад здійснення адміністративно-правового забезпечення господарської діяльності в Україні на основі повного припинення адміністративного тиску на суб' 'єктів господарювання, які вчасно і в повному обсязі сплачують податки та не порушують екологічних норм. Наголошено, шо адміністративний тиск має бути зведено винятково до окремих, вкрай необхідних напрямів у сфері правореалізаиї позитивного публічного адміністрування податків та негативного контролю за дотриманням екологічних норм та комплексного антимонопольного регулювання. Окремо має існувати сервісна діяльність публічної адміністрації, щзо характеризується проявом допомоги суб'єктам правовідносин, що існують в межах аналізованої сфери (суб'єктам господарювання), та слугує фундаментом для забезпечення їх потреб.

Ключові слова: адміністративний тиск, адміністративно-правове забезпечення, господарювання, держава, публічна адміністрація, публічні послуги, сервіс.

A. V. Zamryha. "Administrative service-based nature" as a feature of public administration activities in administrative and legal support of business activity in Ukraine

The article has special features for the "power-service" concept, which is promising in terms of development and development in Ukraine. It is marked that in Ukraine the concept of "power-service" is very promising in terms of development and development, however, for which there is a need for political will, a significant amount of administrative reforms and a great deal of social, long-term to the representatives for the support, and not to the point that the sub-projects for "grace" were not unreleased. The very concept of public servicing and public administration in the field of administrative and legal care of the State of Ukraine is due to the lack of knowledge and reassessment, remodeling and modernization. It was numbered, in order to order the servants $\epsilon$ with the main direct approach to the authorities to a cross-country man, including a sub-grant of the state donation, with the help of the cherished gratification of the needs of the rest, and also to give them the freedom of the lawful rights. It has been revealed that the current concept of public servicing and public administration in the field of administrative and legal care of the state is due to the lack of understanding and revision of the code. The gown about the need for a modern ambush was ambushed. The

(C) А. В. Замрига, 2019

ISSN 2521-6473

Правова позиція, № 3 (24), 2019 
administrative and legal protection of the state grant in Ukraine on the basis of the official administrative grip is often different. It's boggling that the administrative vice of the mother's house has been built up exclusively to some indispensable directions. And in the realm of law enforcement positive public administration and negative control over additional environmental standards and complex antitrust regulation. Separately is the main service of the public administration, which is characterized by the manifestation of the help of the legal subdivisions, which can be understood within the boundaries of the analyzed sphere (the subprojects of the state donation), and this is for the service.

Key words: administrative and legal support, administrative pressure, management, public administration, public services, service, state.

Постановка проблеми. Адміністративно-правове забезпечення господарської діяльності в Україні здійснюється за допомогою різноманітних правових механізмів, які можуть мати як обов'язковий чи то примусовий характер (вказівка на виконання певної дії в національному законі), так і добровільний (дотримання кодексу поведінки). В сукупності або ж відокремлено вони застосовуються для вирішення конкретного завдання та є фундаментом для здійснення публічною адміністрацією своїх повноважень. Уповноважені суб'єкти приймають відповідні рішення, а зобов'язані особи неухильно їх виконують.

Однак чинні сьогодні в Україні державні інститути, в тому числі аналізований, та й загалом весь державний апарат, є громіздкою та неефективною надбудовою на олігархічному фундаменті. В цьому апараті хаотично переплетені радянська бюрократія, бездумні кальки 3 західних інститутів, олігархічні інтереси та корупція. Такий апарат жодним чином не виконує основну функцію держави [1] - служіння громадянському суспільству. Комерціалізація інтересу публічного управління (на центральному, регіональному та місцевому рівнях) деформувала головні функції держави. Проблеми, з якими зіштовхнулося українське суспільство, спричинені нестратегічним політичним баченням тих, хто приймає управлінські рішення і творить загальнонаціональну політику. На жаль, вітчизняна система публічного управління має високий рівень корупційності, що створює суттєві перепони для ефективного функціонування сфер і галузей, важливих для життєдіяльності всіх громадян держави [2, с. 282].

Відповідно, адміністративно-правове забезпечення господарської діяльності в Україні має бути докорінно зміненим, перетвореним з негативного на позитивне. Саме останній передбачає сервісність як основну ознаку та різновид діяльності публічної адміністрації.

Аналіз останніх досліджень і публікацій. Питання вивчення сервісології, сервісної концепції державного управління та сервісного спрямування діяльності публічної адміністрації досліджувалось вченими представниками різних напрямів юридичної науки. Серед них, зокрема, Г. Аванесова, Н. Васильєва, О. Васильєва, Л. Малюк, В. Місюра, П. Петровський, О. Петроє, В. Тимощук, О. Туркова та інші. Однак безпосередньо заявлена до розгляду проблематика не досліджувалась жодним із них.

Мета статті - розкрити особливості концепту «держава-сервіс» як перспективного в аспекті розвитку та становлення в Україні.

Виклад основного матеріалу дослідження. Однією з істотних характеристик держави $\epsilon$ наявність державної влади. Від інших видів соціальної влади державна влада відрізняється тим, що поширюється на всіх членів суспільства, може вирішувати загальносуспільні проблеми, має у своєму розпорядженні специфічний апарат (механізм) управління для здійснення своїх завдань і функцій; тільки вона встановлює формально обов'язкові для усього населення загальні правила поведінки - правові норми [3; 4, с. 6].

Нинішні держави бувають двох типів: держава-поводирь і держава-сервіс. Держава-поводирь - це п'ятирічки, десятирічки, строгий стиль управління. Прикладом такої держави є Китай, Росія, Північна Корея. А держава-сервіс це Америка, країни Свросоюзу, коли є про- 
блема у суспільстві, наприклад аварійність на дорогах, і держава-сервіс буде займатися пониженням відсотку аварійності на дорогах. Чи, наприклад, ГМО-продукція. Коли люди дуже занепокоєні цим питанням, держава-сервіс буде намагатися вирішити це питання. До речі, саме через ці два питання був створений Євросоюз [5].

Зокрема, концепція про державу як надавача послуг населенню і бізнесу набула поширення у 90-ті. Тоді здавалося, що великі війни пішли у минуле і, відповідно, сенс існування держав попередньої доби - оборона від інших держав - вже назавжди зник. Ба більше, як вважалося, держава це аж ніяк не найкращий сервіс, вона лише «поганий учень» приватного сектора. Отже, відповідна концепція наполягала на необхідності конкуренції державних послуг з послугами бізнесу, громад, міжнародних організацій та громадянського суспільства за споживачів громадян та корпорацій. Споживачі отримували свободу вибору, що не могло їм не подобатись. Отже, частково правий Аристотель, який вважав державу необхідним простором для самореалізації людини, яка є «істотою політичною». І марксисти, які розглядали ії як інструмент експлуататорських класів. I націоналісти, які вважали державу вершиною розвитку нації [6].

Таким чином, Україна застрягла у перехідному періоді між цими типами держав. У державі-поводирі усі бояться держави і тому сплачують податки. У країні-сервісі ж населення сплачує податки, бо люди довіряють державі свої гроші і отримують відповідний сервіс. I ось ми застрягли в цьому періоді, бо 99 відсотків тих, хто зараз при владі, були народжені у державі-поводирі, а ми намагаємося розбудувати державу-сервіс. I в принципі у нас керівники не можуть ії побудувати, а люди не готові [5].

Варто констатувати, що за останні три роки нашою державою успішно робиться спроба перейти на новий рівень відносин між громадянином та державою, що передбачає зручні умови отримання, зокрема, адміністративних послуг [7, с. 190]. Однак до повного переходу до так званої моделі «держава-сервіс» Україні ще бракує реалізації відповідних адміністративних реформ. Досить влучними на цей час слід вважати ініціативи публічної адміністрації щодо запровадження електронного урядування. Сервіс iGov запустили в 2015 році як волонтерську ініціативу, аби полегшити співпрацю українців і чиновників та протидіяти корупції. На платформі бізнесмени могли зареєструвати ФОП, отримати необхідну ліцензію або будівельний паспорт. Загалом iGov передбачає близько 400 різних видів послуг. Все це можна було зробити в режимі напівонлайн: тобто замовити довідку і забрати іiї в установі, коли вона буде готова [8]. На цей час відбулась легалізація цього проекту шляхом переходу його у відання та власність держави.

Для того щоб з'ясувати, що передбачає собою сервісність як основна ознака, яка має характеризувати діяльність публічної адміністрації у сфері адміністративно-правового забезпечення господарської діяльності в Україні, вважаємо за необхідне проаналізувати сутнісні характеристики означеної категорії.

У літературі поширеним є трактування сервісу як соціального інституту, під яким мається на увазі стійка форма організації спільної діяльності суб'єктів обслуговування. Система соціальних цінностей, норм і санкцій у сфері сервісу виступає основою взаємин між спільнотами, гарантує спільні зусилля учасників обслуговування, сприяє тиражуванню принципів гостинності та зразків взаємоповаги учасників сервісу [9; 10, с. 4].

Характерною рисою сервісу є те, що сервісна діяльність здатна надбудовуватися над іншою діяльністю як над своїм фундаментом. Основна діяльність (виробництво) неначе задає умови появи, існування й ускладнення сервісної діяльності, що надбудовується. Ця особливість сервісної діяльності формує величезний потенціал для розвитку сервісу та виходу його на передові позиції серед усіх культурних видів діяльності, що й дає підстави говорити про розвиток «сервісної» цивілізації в сучасному світі [10, с. 3$]$.

ISSN 2521-6473

Правова позиція, № 3 (24), 2019 
Сьогодні в суспільстві є громадянський запит до формування та реалізації національної сервісної концепції публічного управління [2, с. 284] - сучасного розуміння соціального призначення держави, за яких пріоритетним завданням демократичного врядування є служіння громадянському суспільству, а основною формою діяльності владних інституцій - надання публічних послуг. У рамках сервісної концепції державного управління влада розглядається як «постачальник послуг», система державного управління - як організація 3 надання державних послуг, а громадянин - як їх замовник і споживач [11, с. 523]. Перехід до орієнтованої на споживача моделі державного управління передбачено нормами Конституції України, ст. 3 якої визначає, що «людина, їі життя і здоров’я, честь і гідність, недоторканність і безпека визнаються в Україні найвищою соціальною цінністю. <..> Утвердження і забезпечення прав і свобод людини є головним обов'язком держави» [7, с. 190; 12].

Відповідно, основними ії рисами є: прозорість і відкритість діяльності органів публічної влади з максимальним орієнтуванням на споживача: вивчення попиту (змісту, розміру i типу) публічних послуг; оптимізація структур управлінського апарату, професіоналізм кадрів, швидке реагування на запити громадян; ефективна конкуренція між публічним і приватним сектором, з метою підвищення якості, доступності й комфортності надання послуг (обслуговування) клієнтів; запровадження приватної відповідальності всіх учасників процесу та публічного контролю за здійсненням усіх необхідних процедур [2, с. 284].

Причому нове державне управління повинно зосереджуватись не стільки на цілях маркетизації державних послуг, скільки на оптимізації системи надання якісних державних послуг для громадян та регуляції ринків публічних послуг. Соціальна спрямованість сервісної політики стає основою для модернізації державного управління розвинутих демократичних країн. Наслідком такої модернізації державного управління постає конкурентоспроможна економіка, заснована на зростанні людського капіталу [13, с. 3].

3 вищенаведеного прослідковується, що сервісність як ознака діяльності публічної адміністрації - це а) утвердження рівності прав і можливостей кожної особистості, скасування необгрунтованих привілеїв, відповідність величини доходу людини витратам праці та капіталу, захист соціально-економічних прав і свобод громадян, соціальний захист непрацездатних і малозабезпечених категорій населення [14, с. 554-555]; б) кооперація зусиль і ресурсів між індивідами, класами, соціальними групами та державою щодо забезпечення співіснування через подолання конфлікту їх інтересів і досягнення домовленості у процесі реалізації взаємоприйнятних завдань [2, с. $283 ; 15$, с. 59].

Отже, інтерпретуючи думку В. Місюри [13, с. 3] до потреб нашого дослідження, вважаємо, що концепція сервісного адміністративно-правового забезпечення господарської діяльності в Україні має спиратись на наступні чотири виміри - принципи сучасної демократичної держави: держава-гарант (тобто система інститутів, що забезпечує надання якісних публічних послуг: дозвільно-реєстраційних, судових, фінансових та інших); держава-партнер (інституційно забезпечує сприятливі умови для самостійного вирішення господарюючим суб'єктом проблем в межах чинного законодавства, політичної системи та економічних умов); держава - інстанція нагляду (на основі встановлених правил суспільної і насамперед економічної діяльності); держава - виконавець послуг для суспільства (насамперед завдання безпеки й можливості держави зробити щось для суб'єкта господарювання з меншими витратами).

Відповідно, саме упорядкування послуг $є$ основним напрямом наближення владних органів до пересічного громадянина, в тому числі й суб’єкта господарювання. Цей процес забезпечить задоволення потреб останнього, а також надасть можливість захисту його прав, свобод і законних інтересів [2, с. 284; 16, с. 381]. 
Серед нагальних нововведень, які потрібно реалізувати з метою розвитку сервісної діяльності публічної адміністрації в аналізованій сфері, необхідно: посилення функції стратегічного планування, включно із стратегічним управлінням соціально-економічним розвитком; вироблення і артикуляція ефективних засобів та методів сервісної політики; встановлення меритократичних критеріїв вертикальної мобільності державних службовців і розробка чітких механізмів службового заохочення на основі критеріїв сервісної діяльності державної служби; орієнтація на соціальні фактори в сучасному державному управлінні має доповнити концепції про визначальну роль економічних факторів в розвитку суспільства і держави; в процесах формування державної політики потрібно оптимізувати співвідношення партикулярних (групових) та загальнонаціональних інтересів; встановлення стандартів якості сервісної діяльності органів державної влади може кардинально знизити корупціогенність управлінської системи старого бюрократичного зразка; підвищення ролі експертної підготовки управлінських рішень і позиціонування науки державного управління з метою неперервної модернізації державної служби на засадах сервісної парадигми [13, с. 3].

Висновки $з$ дослідження і перспективи подальших розвідок у цьому напрямі. Таким чином, проведене дослідження свідчить про необхідність модернізування засад здійснення адміністративно-правового забезпечення господарської діяльності в Україні на основі повного припинення адміністративного тиску на суб'єктів господарювання, які вчасно і в повному обсязі сплачують податки та не порушують екологічних норм.

Іншими словами, воно має бути зведено винятково до окремих, вкрай необхідних напрямів у сфері правореалізації позитивного публічного адміністрування податків та негативного контролю за дотриманням екологічних норм та комплексного антимонопольного регулювання. Окремо має існувати сервісна діяльність публічної адміністрації, що характеризується проявом допомоги суб'єктам правовідносин, що існують в межах аналізованої сфери (суб' єктам господарювання), та слугує фундаментом для забезпечення їх потреб.

В Україні концепт «держава-сервіс» має перспективу в аспекті розвитку та становлення, однак для цього необхідна політична воля керівної еліти, значна кількість адміністративних реформ та загальна зміна соціально-політичного клімату в країні, де громадяни довірятимуть владі, матимуть змогу звертатись до ії представників за допомогою, а не як до необгрунтовано привілейованих суб’єктів за «милостинею». Сама ж нинішня концепція сервісної діяльності публічної адміністрації у сфері адміністративно-правового забезпечення господарської діяльності є недосконалою та вимагає перегляду, перетворення та модернізування, зокрема щодо засад надання публічних послуг.

Список використаних джерел:

1. Дерев’янко Ю. Держава - сервіс. Веб-сайт «Дерев’янко» URL: https://derevyanko.io/ program/derzhava---servs

2. Васильєва Н.В. Сервісна держава: різноманітність розуміння та проблемність побудови. Університетські наукові записки. 2017. № 1. С. 279-288.

3. Державна влада. Юридична енциклопедія: В 6 т. Київ : «Укр. Енцикл.», 1998. Т. 2 : Д-Й. 1999. С. 85.

4. Тимощук В.П. Адміністративні акти: процедура прийняття та припинення дії : монографія. Київ : «Конус-Ю», 2010. 296 с.

5. Костюшко О. Настав час Україні бути державою-сервіс, а не державою-поводир! Інститут журналістики. URL: http://kafedra-press.kiev.ua/novini/648-oleg-kostyushko-nastavchas-ukrayin-buti-derzhavoyu-servs-a-ne-derzhavoyu-povodir.html 
6. Держава - це сервіс? Ні. Скоріше, щось середнє між «спільною справою» і «прирученим бандитом». TEXTY.ORG.UA. 2019. URL: http://texty.org.ua/pg/article/Oximets/read/95177/ Derzhava_ce_servis_Ni_Skorishe_shhos?a_srt $=0$.

7. Туркова О.К. Сервісна спрямованість надання адміністративних послуг в Україні: процедурні аспекти. Право і суспільство. 2015. № 5.2 (3). С. 189-194 .

8. Електронний сервіс iGov перейшов у власність держави. DOJO. 2019. URL: http://www.dojo.net.ua/elektronnyj-servis-igov-perejshov-u-vlasn/.

9. Аванесова Г.А. Сервисная деятельность : уч. пособие. Москва : Аспект Пресс, 2006. $320 \mathrm{c}$.

10. Малюк Л.П. Сервісологія в системі наукового знання. Економіка. Управління. Інновачиї. Серія «Економічні науки». 2016. № 2.12 с.

11. Петровський П. Сервісна концепція державного управління. Енциклопедія державного управління: у 8 т. Національна академія державного управління при Президентові України ; наук.-ред. гол. : Ю. Ковбасюк (голова) та ін. Київ : НАДУ, 2011. Т. 8: Публічне врядування; наук.-ред. кол. : В. Загорський (голова), С. Телешун (співголова) та ін. Львів : ЛРІДУ НАДУ, 2011. С. 523-525.

12. Конституція України : Закон України від 28 червня 1996 р. № 254к/96 ВР. Вiдомості Верховної ради Украӥни. 1996. № 30. С. 141.

13. Місюра В.Я. Сервісна сутність державної політики як основа модернізації державного управління. Державне управління: удосконалення та розвиток. 2015. № 12. С 4.

14. Енциклопедія державного управління : у 8 т.; наук.-ред. кол. : Ю. В. Ковбасюк та ін. Київ : НАДУ.

15. Петроє О.М. Соціальний діалог у державному управлінні: європейський досвід та українські реалії. Київ : НАДУ, 2012. 304 с.

16. Васильєва Н, Васильєва О. Дослідження організації діяльності органів місцевої влади щодо надання послуг. Науковий вісник Академії муніципального управління. Серія «Управління». 2014. № 1. С. 377-384. 
УДК 342.9

DOI https://doi.org/10.32836/2521-6473-2019-3-37-42

\author{
Л. О. Золотухіна, кандидат юридичних наук, \\ доцент, завідувач кафедри цивільно-правових \\ дисциплін Дніпропетровського державного \\ університету внутрішніх справ України
}

\title{
ПРОЯВ ПУБЛІЧНОГО ІНТЕРЕСУ В ОКРЕМИХ РІЗНОВИДАХ АДМІНІСТРАТИВНИХ ПРАВОВІДНОСИН
}

\begin{abstract}
У статті автором здійснюється аналіз проявів публічного інтересу в окремих різновидах адміністративно-правових відносин. Автором зроблено висновок про доиільність оптимізащії системи нормативно-правового регулювання реалізації публічного інтересу в адміністративних правових відносинах. Наголошено, що реалізація публічного інтересу в адміністративних правовідносинах вимагає удосконалення адміністративно-процедурного законодавства. Обтрунтовано, щио ефективність адміністративно-правового механізму забезпечення реалізачії публічного інтересу досягається на нормативно-правовому, організачійно-управлінському та правозахисному рівнях. Розглянуто особливості прояву та реалізації окремих видів публічного інтересу у сфері охорони та захисту громадської моралі, визначення ефективності функиіонування державної служби, захисту економічної конкуренції тощо. Підкреслено, ще в законах сфери публічного права визначається мета їх прийняття, пов'язана із реалізацією та захистом публічних інтересів. 3'ясовано, щя в Украӥні відбувся поступовий перехід від домінування державних інтересів в нормативних приписах до встановлення пріоритету приватних інтересів, починаючи з Конституиї України і продовжуючи гуманізачією законодавства, зміною підходів до правового розуміння, що проявилося навіть у термінологічному підході до розуміння державних та громадських інтересів як інтересів публічних. Обгрунтовано, щзо трансформація законодавства України в новітній історії зумовлена євроінтеграчійними проиесами, прагненням України набути повноправного членства в Свропейському Союзі, в рамках якого досягається оптимальний баланс між публічними та приватними інтересами. Зроблено висновок, щзо в останні роки на заміну концепиії неолібералізму приходить доктрина посилення державного контролю за різними суспільними прочесами $і$ захисту публічних інтересів всього суспільства (що своєю чергою потребує обмеження інтересів приватних).

Ключові слова: адміністративний порядок, адміністративні правовідносини, ознаки, поняття, публічне управління, публічний інтерес.
\end{abstract}

\section{O. Zolotukhina. Public interest in certain types of administrative legal relationships}

The author analyzes the manifestations of public interest in certain types of administrative and legal relations. The author concludes that it is advisable to optimize the system of legal regulation of public interest in administrative legal relations. It is emphasized that realization of public interest in administrative legal relations requires improvement of administrative and procedural legislation. It is substantiated that the effectiveness of the administrative and legal mechanism of ensuring the realization of public interest is achieved at the regulatory, organizational, managerial and human rights levels. The peculiarities of manifestation and realization of certain types of public interest in the field of protection and protection of public morals, determination of efficiency of functioning of the civil service, protection of economic competition, etc. are considered. It is emphasized that the laws of the field of public law determine the purpose of their adoption, related to the implementation and protection of public interests. It has been found out that in Ukraine there has been a gradual transition from dominance of state interests in normative prescriptions to priority setting of private interests, beginning with the Constitution of Ukraine and continuing humanization of legislation, change of approaches to legal understanding, which was manifested even in the terminological approach to public understanding as a public interest. It is substantiated that the transformation of the legislation of Ukraine in the recent history is conditioned by the European integration processes, the desire of Ukraine to acquire full membership in the

\section{(C) Л. О. Золотухіна, 2019}

ISSN 2521-6473

Правова позиція, № 3 (24), 2019 
European Union, within which an optimal balance between public and private interests is reached. It has been concluded that in recent years, the doctrine of strengthening state control over various social processes and protecting the public interests of the whole society (which, in turn, requires the restriction of private interests) has been replaced by the concept of neoliberalism.

Key words: administrative order, administrative legal relations, signs, concepts, public administration, public interest.

Постановка проблеми. Визначення у Конституції України 1996 року найвищою соціальною цінністю людини, іiі життя і здоров'я, честі та гідності стало вирішальним поштовхом до активізації процесів розбудови публічно-сервісної держави. Досягнення результату побудови функціонування держави на засадах «служіння людини» $є$ неможливим без перегляду концептуальних засад адміністративного права як галузі права, норми якої спрямовані на врегулювання управлінських відносин в країні. Саме адміністративне право здатне своїми засобами нормативно-правового регулювання побудувати ефективну модель взаємодії держави та людини, визначити ефективні механізми виконання функцій та завдань системи публічного управління. Отже, беззаперечним $є$ факт того, що адміністративно-правові відносини мають публічно-правовий характер. Реалізація адміністративно-правових відносин нерозривно пов'язана з категорією публічного інтересу, при цьому сутність останнього залишається невизначеною.

Через особливості соціально-історичного розвитку українська адміністративно-правова наука довгі роки не була причетною до дослідження поняття та сутності публічного інтересу, зосереджуючись на суто державних інтересах. Ситуація поступово змінюється з прийняттям Концепції адміністративної реформи в Україні [1].

Аналіз останніх досліджень і публікацій. Дослідження адміністративно-правової категорії «публічний інтерес» є надзвичайно актуальним як у наукових колах, так і серед практиків. Варто виділити наукові розробки таких вчених, як В.Б. Авер'янов, Ю.П. Битяк, В.І. Васильєва, О.В. Гончарук, Б.М. Дронів, С.П. Погребняк, Р.В. Сивий, В.М. Селіванов, В.В. Галунько, Р.А. Калюжний, М.П. Кунцевич, Ю.О. Легеза, С.В. Савченко, О.М. Вінник, С.В. Курінний, В.К. Колпаков, Т.О. Коломоєць, А.Я. Курбатов, С.Т. Гончарук та інші. Однак у дослідженнях представників адміністративної науки встановленню особливостей прояву публічного інтересу у національному законодавстві України присвячено надзвичайно незначну увагу.

Мета статті. Все вищезазначене зумовило мету нашого дослідження, яка полягає у здійсненні проявів публічного інтересу в адміністративно-правових відносинах.

Виклад основного матеріалу дослідження. У сфері адміністративно-правових відносин реалізація «публічного інтересу» в національному законодавстві знайшла своє відображення в Законах України «Про звернення громадян» від 02.10.1996 р., «Про державну службу» від 16.12.1993 р. (наразі це оновлений Закон від 10.12.2015 р.), «Про місцеві державні адміністрації» від 09.04.1999 р. № 586-XIV, «Про адміністративні послуги» від 06.09.2012 р. № 5203-VI, «Про публічні закупівлі» від 25.12.2015 р. № 922-VIII (колишній Закон України «Про закупівлю товарів, робіт і послуг за державні кошти» від 22.02.2000 р. № 1490-ІІІ), «Про доступ до публічної інформації» від 13.01.2011 р., «Про службу в органах місцевого самоврядування» від 07.06.2001 р. № 2493-III, «Про Кабінет Міністрів України» від 27.02.2014 р. № 794-VII, «Про центральні органи виконавчої влади» від 17.03.2011 р. № 3166-VI, «Про запобігання корупції» від 14.10.2014 р. № 1700-VII тощо.

Так, наприклад, одним із принципів державної служби, які визначені у ст. 4 Закону України «Про державну службу» від 10 грудня 2015 року № 889-VIII, є принцип доброчесності, який визначається в законі як спрямованість дій державного службовця на захист публічних інтересів та відмова державного службовця від превалювання приватного інтересу під час здійснення наданих йому повноважень [2]. 
Вказані закони належать до підсистеми публічного права і покликані забезпечити нормальне та ефективне функціонування державного апарату, взаємодію між його структурними елементами, взаємовідносини між державою та особою, знизити корупційні ризики і в кінцевому результаті призвести до задоволення приватних інтересів громадян, що відбувається в процесі реалізації та захисту прав і свобод людини за участю суб'єктів публічної адміністрації. Таким чином, реалізація публічного інтересу, закріпленого у зазначених законах, має неодмінно призвести до покращення механізму реалізації та захисту прав і свобод громадян, тобто задоволення їх приватних інтересів.

Особливе значення для нормативного закріплення та практичної реалізації публічних інтересів українського суспільства має прийняття Кодексу адміністративного судочинства України від 06.07.2005 р. № 2747-IV, яким було розпочато епоху становлення та розвитку адміністративного судочинства, завданням якого, відповідно до ст. 2 КАС України, є справедливе, неупереджене та своєчасне вирішення судом спорів у сфері публічно-правових відносин 3 метою ефективного захисту прав, свобод та інтересів фізичних осіб, прав та інтересів юридичних осіб від порушень з боку суб’єктів владних повноважень [3].

Тобто завданням адміністративних судів є встановлення межі між приватними інтересами особи та публічними інтересами суспільства і держави в особі органів публічної адміністрації - суб'єктів владних повноважень.

Не менш важливою для забезпечення реалізації публічних інтересів в адміністративно-правових відносинах стала судова реформа: внесення змін до Конституції України (Розділ VIII «Правосуддя») та прийняття оновленого Закону України «Про судоустрій і статус суддів» від 02.06.2016 р. № 1402-VIII [4].

Зокрема, новим суб'єктом правотворення став Верховний Суд, правові висновки якого по суті мають прецедентний характер, і в кожній правовій позиції Верховного Суду встановлюється межа між публічними і приватними інтересами, зокрема і в сфері адміністративно-правових відносин. Правові висновки Верховного Суду обов'язкові для всіх нижчих судів, тому їх прецедентний характер і нормативне значення не викликають сумнівів.

У деяких нормативно-правових актах національного законодавства містяться нормативні визначення приватного та публічного інтересів.

Так, в Законі України «Про запобігання корупції» від 14.10.2014 року № 1700-VII у ст. 1 «приватний інтерес» визначається як будь-який майновий чи немайновий інтерес особи, у тому числі зумовлений особистими, сімейними, дружніми чи іншими позаслужбовими стосунками з фізичними чи юридичними особами, у тому числі тими, що виникають у зв'язку з членством або діяльністю в громадських, політичних, релігійних чи інших організаціях.

А реальний конфлікт інтересів визначений як суперечність між приватним інтересом особи та її службовими чи представницькими повноваженнями, що впливає на об'єктивність або неупередженість прийняття рішень, або на вчинення чи невчинення дій під час виконання зазначених повноважень [5].

Таким чином, реальний конфлікт інтересів згідно із Законом України «Про запобігання корупції» це фактично конфлікт між приватними інтересами особи та публічними інтересами всього суспільства та держави в цілому, які ця особа зобов'язана захищати та реалізовувати (задовольняти), використовуючи надані їй повноваження згідно із чинним законодавством.

Непряме визначення публічного (суспільного) інтересу знаходимо в суміжних галузях права. Так, відповідно до ст. 470 Кримінального процесуального кодексу України прокурор під час вирішення питання про укладення угоди про визнання винуватості зобов'язаний враховувати, зокрема, такі обставини: наявність суспільного інтересу в забезпеченні швидкого досудового розслідування і судового провадження; викриття більшої кількості кримінальних

ISSN 2521-6473

Правова позиція, № 3 (24), 2019 
правопорушень; наявність суспільного інтересу в запобіганні, виявленні чи припиненні більшої кількості кримінальних правопорушень або інших більш тяжких кримінальних правопорушень [6].

Показово, що відповідно до ч. 4 ст. 469 Кримінального процесуального кодексу України угода про визнання винуватості між прокурором та підозрюваним чи обвинуваченим може бути укладена у провадженні щодо кримінальних проступків, злочинів невеликої чи середньої тяжкості, тяжких злочинів, внаслідок яких шкода завдана лише державним чи суспільним інтересам [6].

Тобто законодавець у кримінальному процесі чітко розрізняє та розділяє державний та суспільний інтерес.

Разом із тим в сучасній доктрині адміністративного права та чинному адміністративному законодавстві поняття «публічні інтереси» охоплює зміст понять «державні інтереси» та «суспільні інтереси».

Так, згідно з п. 2 ч. 1 ст. 4 Кодексу адміністративного судочинства України публічно-правовий спір - це спір, у якому хоча б одна сторона здійснює публічно-владні управлінські функції, в тому числі на виконання делегованих повноважень, і спір виник у зв'язку із виконанням або невиконанням такою стороною зазначених функцій. А згідно із п. 17 ч. 1 ст. 4 Кодексу адміністративного судочинства України публічна служба - це діяльність на державних політичних посадах, у державних колегіальних органах, професійна діяльність суддів, прокурорів, військова служба, альтернативна (невійськова) служба, інша державна служба, патронатна служба в державних органах, служба в органах влади Автономної Республіки Крим, органах місцевого самоврядування.

Отже, в КАС України «публічна(ий)» означає державний, в той же час «публічний» за своєю етимологією означає «суспільний» (public (англ.) - суспільний, суспільство, відкритий).

Використання категорії «публічний інтерес» в національному законодавстві відповідає європейській моделі, в якій держава та ії структурні елементи мають сервісний характер, представляють та реалізують інтереси всього суспільства, тому більшою мірою використовується термінологія «органи публічної влади», «органи публічної адміністрації».

Отже, в Україні за результатами реформування національного законодавства в контексті євроінтеграційних процесів відбулася термінологічна еволюція - перехід від «державницького» підходу (коли держава є відокремленим владним механізмом, який керує та наглядає за суспільством, і використовується термінологія «державні органи», «державна влада», «державні інтереси») до європейського соціоцентричного підходу, коли держава перебуває на службі у суспільства, захищає та забезпечує реалізацію суспільних інтересів, тому використовується термінологія «публічна служба», «публічні інтереси» тощо.

Серед законів України, в яких домінують публічні інтереси, слід зазначити: Закон України «Про національну безпеку України» від 21 червня 2018 року № 2469-VIII. (регламентує забезпечення демократичного цивільного контролю над органами та формуваннями сектору безпеки і оборони за допомогою запровадження всеосяжного підходу у сферах національної безпеки і оборони); Закон України «Про основні засади державного нагляду (контролю) у сфері господарської діяльності» від 05.04.2007 р. № 877-V; Закон України «Про засади державної регуляторної політики у сфері господарської діяльності» від 11.09.2003 р. № 1160-IV; Закон України «Про судовий збір» від 08.07.2011 р. № 3674-VI; Закон України «Про пробацію» від 05.02.2015 р. № 160-VIII; Закон України «Про захист суспільної моралі» від 20.11.2003 р. № 1296-IV; Закон України «Про захист економічної конкуренції» від 11 січня 2001 р. № 2210-III та інші закони, які віднесені до галузей публічного права і в яких реалізуються та захищаються публічні інтереси всього суспільства та держави. 
Так, у ст. 1 Закону України «Про основні засади державного нагляду (контролю) у сфері господарської діяльності» від 05.04.2007 р. № 877-V зазначається, що державний нагляд (контроль) - це діяльність уповноважених законом центральних органів виконавчої влади, їх територіальних органів, державних колегіальних органів, органів виконавчої влади Автономної Республіки Крим, місцевих державних адміністрацій, органів місцевого самоврядування в межах повноважень, передбачених законом, щодо виявлення та запобігання порушенням вимог законодавства суб'єктами господарювання та забезпечення інтересів суспільства, зокрема, належної якості продукції, робіт та послуг, допустимого рівня небезпеки для населення, навколишнього природного середовища [7].

У ст. 4 Закону України «Про пробацію» зазначено, що метою пробації є забезпечення безпеки суспільства шляхом виправлення засуджених, запобігання вчиненню ними повторних кримінальних правопорушень та забезпечення суду інформацією, що характеризує обвинувачених, з метою прийняття судом рішення про міру їхньої відповідальності [8]. Таким чином, у вказаному законі чітко визначений публічний інтерес - забезпечення безпеки суспільства, запобігання вчиненню засудженими повторних кримінальних правопорушень та забезпечення суду інформацією щодо обвинувачених.

У Законі України «Про захист суспільної моралі» зазначено, що цей Закон встановлює правові основи захисту суспільства від розповсюдження продукції, що негативно впливає на суспільну мораль [9]. В цьому законі публічний інтерес полягає у захисті суспільства від розповсюдження порнографії, пропаганди фашизму та неофашизму, творів, які принижують особистість, тощо. 3 цією метою обмежуються приватні інтереси громадян, встановлюється адміністративна та кримінальна відповідальність за вчинення правопорушень у вказаній сфері суспільних відносин. Особливо актуальною є реалізація даного публічного інтересу в умовах тотальної інформатизації суспільного життя та фактичної відсутності адміністративно-правового регулювання в мережі Інтернет. Незважаючи на наявність вказаного закону та адміністративної і кримінальної відповідальності за відповідні правопорушення, в мережі Інтернет легко знайти твори, відеопродукцію, які негативно впливають на суспільну мораль. Таким чином, публічний інтерес як адміністративно-правова категорія в такому разі не реалізується належним чином, що є суттєвою прогалиною національного законодавства та юридичної практики. Отже, $є$ нагальна потреба врегулювання публічно-правових відносин у мережі Інтернет, встановлення чітких правил надання доступу до інтернет-ресурсів провайдерами, з дотриманням вимог Закону України «Про захист суспільної моралі». Дотримання зазначених правил має контролюватися уповноваженими органами публічної адміністрації, на які буде покладено обов'язок забезпечити реалізацію та захист публічних інтересів у цій сфері.

Преамбула до Закону України «Про захист економічної конкуренції» від 11 січня 2001 р. № 2210-III проголошує, що цей Закон визначає правові засади підтримки та захисту економічної конкуренції, обмеження монополізму в господарській діяльності і спрямований на забезпечення ефективного функціонування економіки України на основі розвитку конкурентних відносин [10]. В такому випадку очевидним $є$ публічний інтерес українського суспільства та держави щодо забезпечення ефективного функціонування економіки України, протидії монополізації господарської діяльності. Такий публічний інтерес реалізує Антимонопольний комітет України, який має для цього достатньо ефективний інструментарій - заходи адміністративної та кримінальної відповідальності.

Висновки 3 дослідження і перспективи подальших розвідок у цьому напрямі. Таким чином, у законах сфери публічного права зазвичай визначається мета їх прийняття, пов'язана iз реалізацією та захистом публічних інтересів. В Україні відбувся поступовий перехід від домінування державних інтересів в нормативних приписах до встановлення пріоритету при-

ISSN 2521-6473

Правова позиція, № 3 (24), 2019 
ватних інтересів, починаючи з Конституції України і продовжуючи гуманізацією законодавства, зміною підходів до праворозуміння, що проявилося навіть у термінологічному підході до розуміння державних та громадських інтересів як інтересів публічних. Трансформація законодавства України в новітній історії зумовлена євроінтеграційними процесами, прагненням України набути повноправного членства в Свропейському Союзі, в рамках якого досягається оптимальний баланс між публічними та приватними інтересами. В останні роки на заміну концепції неолібералізму приходить доктрина посилення державного контролю за різними суспільними процесами і захисту публічних інтересів всього суспільства (що своєю чергою потребує обмеження інтересів приватних). Саме цим зумовлена необхідність доктринального дослідження публічного інтересу як адміністративно-правової категорії.

\section{Список використаних джерел:}

1. Про заходи щодо впровадження Концепції адміністративної реформи в Україні: Указ Президента України від 22 липня 1998 року № 810/98. Офіційний вісник Украӥни. 1999. № 21. Ст. 943.

2. Про державну службу: Закон України від 10 грудня 2015 року № 889-VIII. Дата оновлення: 01.01.2019 p. URL: https://zakon.rada.gov.ua/laws/show/889-19.

3. Кодекс адміністративного судочинства України від 6 липня 2005 року № 2747-IV. Дата оновлення: 04.11.2018 p. URL: https://zakon.rada.gov.ua/laws/show/2747-15.

4. Про судоустрій і статус суддів: Закон України від 02.06.2016 p. № 1402-VIII. Дата оновлення: 05.08.2018 p. URL: https://zakon.rada.gov.ua/laws/show/1402-19.

5. Про запобігання корупції: Закон України від 14.10.2014 p. № 1700-VII. Дата оновлення: 06.06.2019 p. URL: https://zakon.rada.gov.ua/laws/show/1700-18.

6. Кримінальний процесуальний кодекс України від 13 квітня 2012 року № 4651-VI. Дата оновлення: 13.06.2019 p. URL: https://zakon.rada.gov.ua/laws/show/4651-17.

7. Про основні засади державного нагляду (контролю) у сфері господарській діяльності: Закон України від 05.04.2007 p. № 877-V. URL: https://zakon.rada.gov.ua/laws/show/877-16.

8. Про пробацію: Закон України від 05.02.2015 р. № 160-VIII. Дата оновлення: 01.01.2019 p. URL: https://zakon.rada.gov.ua/laws/show/160-19.

9. Про захист суспільної моралі: Закон України від 20.11.2003 р. № 1296-IV. Дата оновлення: 09.12.2015 p. URL: https://zakon.rada.gov.ua/laws/show/1296-15.

10. Про захист економічної конкуренції: Закон України від 11 січня 2001 р. № 2210-III. Дата оновлення: 07.03.2018 p. URL: https://zakon.rada.gov.ua/laws/show/2210-14. 
О. Л. Коліуш, здобувач кафедри адміністративного та митного права Університету митної справи та фрінансів

\section{УДОСКОНАЛЕННЯ ПРАВОВОГО РЕГУЛЮВАННЯ ТА СИСТЕМИ ІНФОРМАЦЙНОГО ЗАБЕЗПЕЧЕННЯ ЯК НАПРЯМ ЗАПОБІГАННЯ КОРУПЦІЇ ПІД ЧАС НАДАННЯ АДМІНІСТРАТИВНИХ ПОСЛУГ}

Стаття присвячена удосконаленню правового регулювання та системи інформаційного забезпечення як напряму запобігання корупиії під час надання адміністративних послуг. Обтрунтовано доцільність негайного ухвалення законопроекту № 4267-1 від 23.03.2016 як Закону України «Про внесення змін та доповнень до Закону України «Про адміністративні послуги», який зміцнить нормативну базу надання адміністративних послуг органами публічної адміністрації фізичним або юридичним особам, котре здійснюється в електронному виглядi, i сприятиме запобіганню корупиї під час надання адміністративних послуг взагалі.

Встановлено, що наявність корупиійних налагоджених механізмів у вітчизняній системі адміністративного управління, що склалася традииійно, робить проблему налагодження електронного надання адміністративних послуг такою, що виходить за межі суто технічно-інформаційних. Оптимізація публічного управління шляхом переходу до електронного уряду пов'язана з необхідністю адаптації старих умов i звичних патернів відносин між суб' єктами влади і суб 'єктами звернень до нових умов, інакше кажучи, із соиіально-інституиіональною адаптацією. Такий перехід являє собою тривалий процес, ускладнений конфліктами і навіть боротьбою, яка виявляє себе як у правовому, так і в політичному полі.

Доведено, щуо використання сучасних інформаиійних технологій виступає як дієвий спосіб уникнути корупційних ризиків. Але при иъьому не слід обходити увагою ще один рівень інформачійного напряму забезпечення процедури надання адміністративних послуг. Налагодженням механізму надання електронних послуг справа не завершується; супроводжувати його функиіонування мають багатоаспектні механізми безпеки інформачійного простору, щоб убезпечити споживачів послуг від можливого втручання інших осіб, які за посереднищтвом кібератак можуть отримати доступ до особистих даних. Тому удосконалення ивого аспекту надання адміністративних послуг має відбуватися на умовах міждисииплінарного пошуку та постійної співпраці адміністративістів і фахівиів з IT-технологій.

Ключові слова: послуга, адміністративна послуга, запобігання корупиїі, корупиія, напрями, система інформаційного забезпечення.

O. L. Koliush. Improvement of legal regulation and data intelligence system as directions to prevent corruption during provision of administrative services

The scientific article is devoted to the improvement of the right regulation and information support system as a way of preventing corruption in the provision of administrative services. The expediency of the immediate adoption of the bill No. 4267-1 of 23.03.2016 as the Law of Ukraine "On Amendments to the Law of Ukraine" On Administrative Services is substantiated and will help to prevent corruption in the provision of administrative services in general.

It is proved that the use of modern information technologies acts as an effective way to avoid corruption risks. However, one should not overlook another level of information direction of ensuring the procedure of providing administrative services. Establishing a mechanism for providing electronic services is not complete; its multifaceted security mechanisms are in place to keep it functioning in order to protect service users from the possible interference of others who, through cyber attacks, can access personal data. Therefore, the improvement of this aspect of administrative services should be done on the basis of interdisciplinary search and continuous cooperation of administrators and IT specialists.

(C) О. Л. Коліуш, 2019

ISSN 2521-6473

Правова позиція, № 3 (24), 2019 
It is proved that the use of modern information technologies acts as an effective way to avoid corruption risks. However, one should not overlook another level of information direction of ensuring the procedure of providing administrative services. Establishing a mechanism for providing electronic services is not complete; its multifaceted security mechanisms are in place to keep it functioning in order to protect service users from the possible interference of others who, through cyber attacks, can access personal data. Therefore, the improvement of this aspect of administrative services should be done on the basis of interdisciplinary search and continuous cooperation of administrators and IT specialists.

Key words: service, administrative service, corruption prevention, corruption, referrals, information support system.

Постановка проблеми. Нині на розгляді й опрацюванні Комітету з питань державного будівництва, регіональної політики та місцевого самоврядування перебуває досить вдалий, на наш погляд, законопроект України № 4267-1 від 23.03.2016 «Про внесення змін та доповнень до Закону України «Про адміністративні послуги» [1] щодо покращення умов надання адміністративних послуг, підготований групою народних депутатів (Є.В. Соболєв, А.А. Романова, Є.П. Фірсов, В.В. Пацкан, Л.О. Смець, П.П. Костенко, М.В. Кобцев, Я.В. Маркевич, Д.С. Добродомов, І.І. Мельничук).

Законопроект передбачає внесення змін до Закону України «Про адміністративні послуги» [1] щодо доповнення переліку суб'єктів надання адміністративних послуг акредитованими суб'єктами, вимоги та порядок акредитації яких встановлюватимуться Кабінетом Міністрів України. Коло адміністративних центрів доповнюється можливістю створення їх обласними державними адміністраціями на обласному рівні. Закріплюється можливість отримання адміністративної послуги незалежно від місця знаходження суб'єкта надання адміністративної послуги, а також суб'єкта звернення, місця провадження його діяльності та місця знаходження відповідного об'єкта, крім випадків, установлених законом (екстериторіальність), можливість подання електронних заяв на отримання адміністративних послуг напряму через вебсайти суб'єктів їх надання. Суб'єктам надання адміністративних послуг забезпечується безоплатний віддалений доступ через відкриті для них та адміністраторів центри надання адміністративних послуг, АРІ-адреси до інформаційних систем та електронних баз даних (реєстрів), що містять інформацію, необхідну для надання адміністративних послуг. Суб’єкти надання адміністративних послуг зобов'язуються надавати в електронній формі усі адміністративні послуги, крім тих, результат надання яких відповідно до закону потребує використання спеціальних бланків та/або інших особливих матеріальних форм свого виразу (паспорти, пластикові картки, автомобільні номери тощо). Встановлюється, що 40\% адміністративного збору спрямовується до відповідного бюджету, а 60\% - безпосередньо акредитованому суб'єкту.

Мета статті - дослідити можливості удосконалення правового регулювання та системи інформаційного забезпечення як напряму запобігання корупції під час надання адміністративних послуг.

Виклад основного матеріалу. Розглянемо деякі положення цього законопроекту більш детально. Не можна не звернути увагу на цікаві та обгрунтовані пропозиції в зазначеному законопроекті. Зокрема, пропонується доповнення статті 1 новим визначенням поняття «електронна заява», під яким розуміється заява про отримання адміністративної послуги, яка формується і подається через вебсайт суб'єкта надання адміністративних послуг або через Єдиний державний портал адміністративних послуг, у тому числі через інтегровані з ним інформаційні системи державних органів та органів місцевого самоврядування.

Дуже слушною є пропозиція щодо внесення змін до статті 9 Закону України «Про адміністративні послуги» [2], а саме: у першому реченні абзацу другого частини першої після слів «в електронній формі надаються» додати слова «через вебсайти суб’ єктів надання адмі- 
ністративних послуг або»; частину другу викласти в такій редакції: «2. Суб’єкт звернення має право на отримання адміністративної послуги незалежно від місця знаходження суб'єкта надання адміністративної послуги, а також суб'єкта звернення (включаючи реєстрацію місця проживання фізичної особи), місця провадження його діяльності та місця знаходження відповідного об'єкта (екстериторіальність), крім випадків, установлених законом»; частину третю виключити; в абзаці другому частини четвертої після слів «в електронній формі» додати слова «(електронна заява) - через веб-сайт суб'єкта надання адміністративних послуг або»; у частині восьмій після слів «шляхом прямого доступу» додати слова «через відкриті API-адреси»; у частині дев'ятій: у пункті 4 після слів «у тому числі через» додати слова «відкриті АРІ-адреси відповідних інформаційних систем та електронних баз даних (реєстрів) та»; пункт 5 викласти в такій редакції: «5) забезпечити надання в електронній формі усіх адміністративних послуг, крім тих, результат надання яких відповідно до закону потребує використання спеціальних бланків та/або інших особливих матеріальних форм свого виразу (паспорти, пластикові картки, автомобільні номери тощо)».

Також вважаємо слушними формулювання пропонованих змін до статті 12 Закону України «Про адміністративні послуги» [2] щодо суб' єктів надання адміністративних послуг, а саме: «У разі неутворення обласними чи районними державними адміністраціями центрів надання адміністративних послуг у населених пунктах, які є адміністративними центрами областей, районів і Автономної Республіки Крим, а також у містах та Севастополі, центри надання адміністративних послуг, що утворені у Києві за рішенням відповідних селищних або міських рад, можуть забезпечувати надання адміністративних послуг, у тому числі відповідними обласними, районними та міськими державними адміністраціями, на основі узгоджених рішень.

У разі утворення центрів надання адміністративних послуг районними та/або обласними державними адміністраціями такі центри можуть забезпечувати надання адміністративних послуг обласних, районних державних адміністрацій та органів місцевого самоврядування на основі їх узгоджених рішень».

Аналізуючи текст чинного Закону «Про адміністративні послуги» [2], у ст. 5 його знаходимо вимогу, згідно з якою встановлення підстав для одержання адміністративної послуги, коло суб'єктів надання адміністративної послуги та їх повноваження, перелік та вимоги до обов'язкових для отримання адміністративної послуги документів, платність або безоплатність надання адміністративної послуги, терміни їх надання та підстави для відмови у наданні адміністративної послуги визначаються винятково законами України. Однак коментатори Закону зазначають, що такі положення, як перелік та вимоги до документів, необхідні для отримання адміністративної послуги; умови платності або безоплатності її надання, підстави для відмови у її наданні, на жаль, не знайшли чіткого затвердження в жодному законодавчому акті. Зазначені положення, на наш погляд, також потребують необхідної нормативної регуляції за допомогою внесення змін до Закону України «Про адміністративні послуги».

Позитивно оцінюючи запропоновані законопроектом нововведення, підтримуємо пропозицію про негайне ухвалення законопроекту № 4267-1 від 23.03.2016 як Закону України «Про внесення змін та доповнень до Закону України «Про адміністративні послуги», що, на нашу думку, зміцнить нормативну базу надання адміністративних послуг органами публічної адміністрації фізичним або юридичним особам, котре здійснюється в електронному вигляді, і сприятиме запобіганню корупції під час надання адміністративних послуг взагалі.

Питання удосконалення системи інформаційного забезпечення запобігання корупції під час надання адміністративних послуг заслуговує на окрему увагу.

Висвітлюючи це питання, насамперед необхідно зазначити, що вітчизняна практика надання адміністративних послуг зробила великий крок уперед. Наприклад, ще у 2009 р.

ISSN 2521-6473

Правова позиція, № 3 (24), 2019 
опитування споживачів адміністративних послуг переконливо демонструвало незадоволеність громадян та підприємців України відсутністю з боку адміністративних органів і їх осіб чітких пояснень щодо того, які саме документи потрібні для вирішення справи, через що вони були змушені відвідувати орган влади по декілька разів. За даними «Аналітичного звіту щодо корупційних ризиків», на це найчастіше нарікали підприємці з числа тих, які зверталися за послугами і залишилися незадоволеними (57,6\%), а також 48,7\% населення, які зверталися за послугами і залишилися незадоволеними [3]. Сьогодні споживач, що має доступ до мережі Інтернет, може відвідати, наприклад, сторінку Порталу державних послуг [4], на якій міститься інформація щодо потрібних для отримання конкретної послуги документів і логічної послідовності необхідних дій. Однак вважати сьогоденну ситуацію оптимальною, на жаль, ще зарано.

Безумовно, загальнодоступність та відкритість інформації про адміністративну послугу позбавляє багатьох потенційних споживачів адміністративних послуг потреби звертатися за особистою консультацією до посадової особи органу публічної адміністрації. Крім отримання інформації електронним шляхом, Інтернет гіпотетично дозволяє в такий самий спосіб безпосередньо звертатися за адміністративними послугами (а в перспективі - і отримати багато які з них). Проте якщо проблема відсутності або поганої доступності інформації про надання адміністративної послуги за допомогою всесвітньої мережі майже знята (чому «майже», пояснимо нижче), то електронне отримання зазначеної послуги все ще залишається для українських фізичних і юридичних осіб нереалізованою мрією. Так, на сторінках Порталу можемо знайти багато пропонованих послуг, але спроба замовити яку-небудь 3 них завершується ввічливим зверненням «На жаль, ця послуга є недоступною для Вашого регіону».

Щодо безпосереднього надання інформації про порядок отримання послуги й необхідні для цього документи, то й тут не все можна вважати функціонально оптимальним. По-перше, як зазначає М.Б. Острах, на практиці обсяг інформації, яку можна отримати в приміщенні адміністративного органу і на офіційній вебсторінці, суттєво відрізняється від належного і залежить насамперед від організаційних чинників та ініціативності керівництва органу [5, с. 162]. По-друге, Інтернет-споживачами є не всі громадяни України. Сьогодні серед показників соціального становища населення фахівці виділяють так зване «цифрове розшарування» - поділ на тих, хто має доступ до Інтернету, та тих, у кого такий доступ відсутній; згідно з даними Київського міжнародного інституту соціології у 2016 році доля споживачів Інтернету серед мешканців нашої країни досягла 62\% [6]. Це, звичайно, немало, але слід мати на увазі, що $38 \%$ населення теоретично не можуть отримати необхідну інформацію щодо адміністративних послуг за допомогою Порталу або вебсторінок регіональних ЦНАПів.

Інформаційне охоплення цієї частини населення має відбуватися передусім за допомогою розміщення відомостей у приміщеннях адміністративного органу, призначених для особистого прийому, на інформаційних стендах, де для загального огляду має вивішуватися інформація щодо процедури надання адміністративної послуги, структурного підрозділу, до якого необхідно звернутися, переліку необхідних документів, прийомних днів та годин прийому, строків розгляду звернення, розміру та порядку сплати збору (плати), інформації про законодавство, яке регулює порядок надання тієї чи іншої адміністративної послуги, а також контактний номер телефону, за яким споживач адміністративної послуги може уточнити необхідну для нього інформацію, зразки заповнених документів тощо. Доцільно встановлювати у приміщенні органів публічної адміністрації, які надають адміністративні послуги, спеціальні термінали, за допомогою яких відвідувачі адміністративних органів зможуть отримати ту ж інформацію, яка буде міститися на вебсторінці даного органу. Безумовно, інформація повинна надаватися безоплатно та бути загальнодоступною. Крім того, відомості про процедуру надання адміністративної послуги можуть також поширюватися через видання буклетів 
(брошур) та їх безоплатне розповсюдження у приміщенні адміністративного органу або відправлення за допомогою поштового зв'язку (за запитом особи). Таким чином, жодна особа не буде обмежена у своєму праві отримати повну та достовірну інформацію, у тому числі з використанням новітніх технологій.

Крім того, для модернізації інформаційної роботи навколо надання адміністративних органів створювались консультаційні кабінети, довідкові служби, в тому числі служби телефонної довідки. Проте практика свідчить, що ефективність цих нововведень не є дуже високою: за словами М.Б. Остраха, навіть телефонні довідки в публічній адміністрації є рідкістю, а консультаційні кабінети функціонують лише в окремих органах, які мають справу з питаннями підприємництва [5, с. 162]. Зробила свій внесок і традиційна для органів влади ситуація стабільного телефонного сигналу «зайнято» або відсутності відповіді, що додатково доводить невелику користь телефонного зв'язку у справі інформування населення, зацікавленого в отриманні адміністративних послуг.

Усе вищезазначене свідчить, що одним із перспективних способів запобігання корупції під час надання адміністративних послуг є інформаційно-довідкове сповіщення та провадження консультацій в онлайн режимі. Для цього необхідно забезпечити посадових осіб органів публічної адміністрації належними інформаційно-комунікаційними технологіями. 3 метою забезпечення споживачів адміністративних послуг відомостями про процедуру отримання адміністративної послуги необхідно створювати та забезпечувати, оновлювати й підтримувати функціонування вебсторінок, інших електронних ресурсів адміністративних органів.

Стосовно можливості сьогодні в Україні отримати адміністративні послуги в електронному вигляді можемо зазначити таке. Згідно зі ст. 9 Закону «Про адміністративні послуги» споживач такої послуги може ініціювати ії надання, подавши заяву в усній, письмовій або електронній формі. Однак практика демонструє, що здебільшого споживачі вимушені особисто звертатися за адміністративною послугою, тоді як за висновками науковців «одним 3 найбільших корупційних ризиків у сфері надання адміністративних послуг є можливість (а часто - вимушеність) особистого спілкування (контакту) приватної особи - споживача адміністративної послуги з посадовою особою адміністративного органу, яка надає адміністративну послугу (вирішує справу по суті або готує проект рішення)» [5, с. 158].

Існування корупційних налагоджених механізмів у вітчизняній системі адміністративного управління, що склалася традиційно, робить проблему налагодження електронного надання адміністративних послуг такою, що виходить за межі суто технічно-інформаційних. Оптимізація публічного управління шляхом переходу до електронного уряду пов'язана з необхідністю адаптації старих умов і звичних патернів відносин між суб'єктами влади і суб'єктами звернень до нових умов, інакше кажучи, із соціально-інституціональною адаптацією. Такий перехід являє собою тривалий процес, ускладнений конфліктами і навіть боротьбою, яка виявляє себе як у правовому, так і в політичному полі.

Висновки 3 дослідження і перспективи подальших розвідок у цьому напрямі. Таким чином, використання сучасних інформаційних технологій виступає як дієвий спосіб уникнути корупційних ризиків. Але при цьому не слід обходити увагою ще один рівень інформаційного напряму забезпечення процедури надання адміністративних послуг. Налагодженням механізму надання електронних послуг справа не завершується; супроводжувати його функціонування мають багатоаспектні механізми безпеки інформаційного простору, щоб убезпечити споживачів послуг від можливого втручання інших осіб, які за посередництвом кібератак можуть отримати доступ до особистих даних. Тому удосконалення цього аспекту надання адміністративних послуг має відбуватися на умовах міждисциплінарного пошуку та постійної співпраці адміністративістів і фахівців з ІТ-технологій.

ISSN 2521-6473

Правова позиція, № 3 (24), 2019 


\section{Список використаних джерел:}

1. Про внесення змін та доповнень до Закону України «Про адміністративні послуги» щодо покращення умов надання адміністративних послуг» : законопроект ВРУ України № 4267-1 від 23.03.2016. URL: http://w1.c1.rada.gov.ua/pls/zweb2/webproc4_1?pf3511=58495.

2. Про адміністративні послуги: Закон України від 06.09.2012 № 5203-VI / Верховна Рада Украӥни. Відомості Верховної Ради Украӥни. 2013. № 32. Ст. 409.

3. Аналітичний звіт щодо корупційних ризиків у сферах надання адміністративних послуг та контрольно-наглядової діяльності публічної адміністрації в Україні / Відділ проблем економічної злочинності, Директор з питань співробітництва Генерального директора прав людини і правових питань, квітень 2009. URL: www.guds.gov.ua/control/uk/publish/printable article?art_id=198893.

4. Портал державних послуг. URL: https://igov.org.ua/1.

5. Острах М.Б. Провадження з надання адміністративних послуг в Україні : дис. канд. юрид. наук : 12.00.07; Міжн. університет бізнесу і права. Херсон, 2013. 236 с.

6. Проникнення Інтернету в Україні. URL: http://www.kiis.com.ua/?lang=ukr\&cat=pub. 
УДК 342.95

DOI https://doi.org/10.32836/2521-6473-2019-3-49-55

\section{С. П. Параниця, кандидат юридичних наук,} доцент, заступник начальника кафедри оперативнорозшукової діяльності Університету державної фріскальної служби України

\section{А. В. Алентьєва, здобувач вищої освіти другого магістерського рівня Університету державної фріскальної служби України}

\section{ПРАВОВИЙ СТАТУС ВІДПОВІДАЛЬНОГО ПРАЦІВНИКА СУБ' ПЕРВИННОГО ФІНАНСОВОГО МОНТТОРИНГУ}

У статті розглядається питання правового статусу відповідального працівника суб’єкта первинного фінансового моніторингу України. Визначено основні структурні елементи правового статусу иієї особи. Ефективність втілення покладених функиій даних суб'єктів пред'являє до їх представників особливі вимоги - кваліфікації і навички під час здійснення професійних компетенцій, певним чином відрізняючи від інших сфер суспільних відносин. Проаналізовано теоретичні підходи до призначення відповідального працівника, яке повинно бути здійснено після перевірки ділової репутації кандидата на посаду відповідального прачівника, за результатами якої встановлено, щчо кандидат має бездоганну ділову репутачію на підставі наданих оригіналів документів: паспорта, трудової книжки, документів про освіту та/або підвищення кваліфікаиії, сертифіката на право здійснення професійної діяльності на фондовому ринку, довідки про відсутність судимості, отриманої в органах внутрішніх справ, та анкети ділової репутації, яка заповнюється кандидатом на посаду відповідального прачівника. Зазначається, щз система фінансового моніторингу покликана бути одним із регуляторів економічної безпеки України, фінансовий моніторинг слід розглядати не тільки в контексті заходів відповідних суб'єктів, а й як інструмент адміністративного впливу, який забезпечує гарантування національної безпеки. Фінансовий моніторинг, як один із таких інструментів, спрямований на унеможливлення реалізації наймасштабніших за обсягами операщій з фінансовими ресурсами, тобто операцій щодо легалізаиії доходів, одержаних злочинним шляхом.

Приділяється увага терміну «бездоганна ділова репутація» як обов'язкового елементу кваліфікаиійних вимог до осіб, які можуть бути призначеними на посаду відповідального за проведення фінансового моніторингу. Стверджується, що на законодавчому та теоретичному рівнях правовий статус розглядається як сукупність структурних елементів, які й визначають його зміст. До змісту правового статусу додатково відносимо структурні елементи свободи, законні інтереси й деліктоздатність.

Ключові слова: правовий статус, державний фінансовий моніторинг, відповідальний працівник суб'єкта первинного фінансового моніторингу, суб'єкти державного фінансового моніторингу.

S. P. Paranytsia, A. V. Alentyeva. Legal status of the responsible employee of the principal financial monitor subject

The article deals with the legal status of the responsible employee of the subject of the primary financial monitoring of Ukraine. The basic structural elements of this person's legal status are identified. The effectiveness of the implementation of the assigned functions of these subjects presents to their representatives special requirements - qualifications and skills in the exercise of professional competencies, in some ways different from other spheres of public relations. Theoretical approaches to the appointment of a responsible employee, which should be carried out after checking the business reputation of the candidate for the position of responsible employee, which results in finding that the candidate has a perfect business reputation on the basis of the submit-

(C) С. П. Параниця, А. В. Алентьєва, 2019

ISSN 2521-6473

Правова позиція, № 3 (24), 2019 
ted original documents: passport, workbook, or educational documents professional development, certificate for the right to carry out professional activity in the stock market, certificate of absence of criminal record obtained in law enforcement agencies, questionnaire and goodwill, which is filled with a candidate for the compliance officer. The totality of the confirmed information about the responsible employee gives an opportunity to make a conclusion about the responsibility of its activity to the requirements of the legislation, as well as about the absence of a criminal record, which has not been withdrawn or repaid in accordance with the procedure established by law. It is noted that the system of financial monitoring is intended to be one of the regulators of the economic security of Ukraine, financial monitoring should be considered not only in the context of the measures of the respective entities, but also as a tool of administrative influence that ensures the guarantee of national security. Financial monitoring, as one such tool, is aimed at preventing the implementation of the largest scale transactions with financial resources, transactions on the legalization of proceeds from crime.

Attention is drawn to the term "perfect business reputation" as a mandatory element of the qualification requirements for persons who may be appointed to the position of responsible for financial monitoring. It is argued that at the legislative and theoretical levels, legal status is seen as a set of structural elements that determine its content. The content of the legal status is additionally attributed to the structural elements of freedom, legitimate interests and tort.

Key words: legal status, state financial monitoring, responsible employee of the entity of primary financial monitoring, subjects of state financial monitoring.

Постановка проблеми. На систему органів виконавчої влади покладаються обов’язки iз вирішення та втілення положень, стратегій, приведення в життя нормативних актів, здійснення контролю та нагляду за реалізацію законів. Ефективність втілення покладених функцій на органи виконавчої влади залежить не тільки від наявності достатніх положень, а й від визначеності місця кожного суб'єкта. Діяльність даних суб'єктів пред’являє до їх представників особливі вимоги - кваліфікації і навички під час здійснення професійних компетенцій, певним чином відрізняючи від інших сфер суспільних відносин. Фінансовий моніторинг, як один із таких інструментів, спрямований на унеможливлення реалізації наймасштабніших за обсягами операцій з фінансовими ресурсами, тобто операцій щодо легалізації доходів, одержаних злочинним шляхом. Варто зазначити, що в цьому аспекті необхідно визначити правовий статус відповідального працівника суб'єкта первинного фінансового моніторингу.

Аналіз останніх досліджень і публікацій. Питанням правового статусу фінансового моніторингу в Україні присвячені наукові праці В.Т. Білоуса, С.А. Буткевича, С.В. Васильчака, I.М. Гаєвського, В.А. Журавля, О.Г. Комісарова, О.С. Користіна, В.Л. Кротюка, В.А. Некрасова, В.М. Поповича, О.Ю. Скрипки, С.В. Сімов'яна, А.О. Собакарь, В.А. Тимошенка, О.Ю. Фещенка та інших. На жаль, нині немає доволі чіткого підходу до критерію розуміння дефініції правового статусу відповідального працівника суб'єкта первинного фінансового моніторингу.

Метою статті $є$ обгрунтування та аналіз нормативних актів, визначення ролі і місця відповідального працівника суб’єкта первинного фінансового моніторингу України щодо особливостей та структурних елементів.

Виклад основного матеріалу. Згідно з частиною 1 статті 5 Закону України «Про запобігання та протидію легалізації (відмиванню) доходів, одержаних злочинним шляхом, фінансуванню тероризму та фінансуванню розповсюдження зброї масового знищення» від 14 жовтня 2014 року № 1702-VII [1] система фінансового моніторингу складається 3 двох рівнів - первинного та державного. Пункт 1 статті 6 Закону України визначає, що суб'єкт первинного фінансового моніторингу з урахуванням вимог законодавства, нормативно-правових актів Спеціально уповноваженого органу та інших суб'єктів державного фінансового моніторингу встановлює правила, розробляє програми проведення фінансового моніторингу та призначає працівника, відповідального за його проведення, крім спеціально визначених суб'єктів первинного фінансового моніторингу [1]. 
У законодавчому полі визначено, що у суб'єктів первинного фінансового моніторингу можуть створюватися або посада відповідального працівника суб'єкта первинного фінансового моніторингу, або, за необхідності, цілий відділ, зважаючи на розміри фінансової установи, яка має здійснювати фінансовий моніторинг.

Перша вимога, що стосується правового статусу відповідального працівника, визначає його керівну роль у суб'єктів первинного фінансового моніторингу - він призначається за посадою на рівні керівництва. Така вимога національного законодавства зумовлюється міжнародним стандартом, а саме 18-ю Рекомендацією FATF, яка разом із Методологією їі оцінки передбачає, що суб'єкти первинного фінансового моніторингу повинні бути зобов'язані впроваджувати програми з протидії відмиванню коштів та фінансування тероризму, які стосуються ризиків та розміру діяльності та які включають заходи щодо виконання вимог на рівні керівництва (в тому числі призначення відповідального працівника на рівні керівництва) [2].

FATF змусила нас поставити «по один бік барикади» тих, хто традиційно стояв в Україні по різні боки, а саме: регуляторів та учасників ринків. Фактично, законодавчі та нормативні акти, розроблені на вимогу FATF та інших міжнародних фінансових організацій, вперше перевели в практичну площину питання про доброчесність фінансового бізнесу в нашій країні. Дозволю собі навіть висловити припущення, що внаслідок впровадження принципів FATF в Україні з'явиться, нарешті, реальне підгрунтя для появи справжніх саморегулівних організацій (СРО), адже досі ці об'єднання є не більш ніж лобістськими асоціаціями, налаштованими на «боротьбу з владою» [3].

Деякі особливості статусу цієї особи визначено й у Положенні про здійснення фінансового моніторингу професійними учасниками ринку цінних паперів, затвердженому Рішенням Національної комісії з цінних паперів та фондового ринку від 19.07.2012 № 995 [4]. Зокрема, у ньому уточнено процедуру призначення цієї особи на посаду та її звільнення з посади, заміщення особи, документального оформлення результатів відбору кандидата, наголошено на необхідності перевірки бездоганної ділової репутації кандидата на посаду, а також необхідності професійної підготовки відповідального працівника [5].

Бездоганна ділова репутація (пункт 2 частини першої статті 1 Закону) визначається сукупністю підтвердженої інформації про відповідального працівника, що дає можливість зробити висновок про відповідальність їі діяльності вимогам законодавства, а також про відсутність судимості, яка не знята або не погашена в установленому законом порядку.

У ході перевірки бездоганної ділової репутації слід враховувати не лише інформацію про відсутність судимості, а й оцінювати такі якості кандидата, як чесність, добропорядність, відданість. У зв'язку із цим пропонується використовувати (за згодою кандидата) психологічні методики оцінювання особистості, а також можливості поліграфічної апаратури. Також встановленню наявності цього критерію сприятиме вивчення документів, що надаються претендентом, підтримання зв'язків із його колишніми роботодавцями, спілкування із фахівцями, що мали службові взаємовідносини з кандидатом.

Нормативними актами Держфінмоніторингу України деталізовано положення основного антилегалізаційного закону. Зокрема, встановлено кваліфікаційні вимоги до працівника суб'єкта первинного фінансового моніторингу (крім банків), відповідального за проведення фінансового моніторингу у сфері запобігання та протидії легалізації (відмиванню) доходів, одержаних злочинним шляхом, і фінансуванню тероризму [6]. Так, відповідальний працівник очолює та координує внутрішню систему запобігання та протидії легалізації (відмиванню) доходів, одержаних злочинним шляхом, і фінансуванню тероризму суб'єкта первинного фінансового моніторингу. Він призначається за посадою на рівні керівництва суб'єкта первинного фінансового моніторингу, а також повинен знати законодавство України та міжнародні стандарти у сфері запобі-

ISSN 2521-6473

Правова позиція, № 3 (24), 2019 
гання та протидії легалізації (відмиванню) доходів, одержаних злочинним шляхом, і фінансуванню тероризму та володіти навичками щодо застосовування в практичній діяльності:

- правил проведення внутрішнього фінансового моніторингу та програм його здійснення;

- порядку виявлення фінансових операцій, що підлягають фінансовому моніторингу та які можуть бути пов'язані, мати відношення та/або призначатися для фінансування тероризму;

- порядку ідентифікації осіб, що здійснюють фінансові операції, та отримання і зберігання документів, що стосуються ідентифікації осіб, та документації про здійснення фінансової операції;

- порядку реєстрації суб'єктом первинного фінансового моніторингу фінансових операцій, що підлягають фінансовому моніторингу;

- порядку зупинення фінансових операцій;

- порядку подання Держфінмоніторингу України інформації про фінансові операції, що підлягають фінансовому моніторингу або стали об'єктом фінансового моніторингу, та сприяння суб'єктам державного фінансового моніторингу у проведенні аналізу таких фінансових операцій;

- порядку підготовки персоналу суб'єкта первинного фінансового моніторингу з метою виявлення фінансових операцій, що підлягають фінансовому моніторингу;

- критеріїв оцінки ризику проведення операцій, що можуть бути пов'язані з легалізацією (відмиванням) доходів, одержаних злочинним шляхом, чи фінансуванням тероризму;

- порядку повідомлення правоохоронних органів про фінансові операції, щодо яких $€$ або має бути підозра, що вони пов'язані, мають відношення або призначені для фінансування терористичної діяльності, терористичних актів чи терористичних організацій;

- вимог щодо запобігання розголошенню інформації, яка надається Держфінмоніторингу України, іншої інформації з питань фінансового моніторингу, у тому числі про факт ії̈ подання;

- інших вимог, що покладаються на суб'єкта первинного фінансового моніторингу відповідно до законодавства у сфері запобігання та протидії легалізації (відмиванню) доходів, одержаних злочинним шляхом, і фінансуванню тероризму.

Гаєвський І.М. стверджує, що відповідальний працівник є ключовою фігурою в суб'єкті первинного фінансового моніторингу, що у співпраці із керівником координує антилегалізаційні заходи на рівні суб'єкта [7, с. 162].

О.Г. Комісаров, О.Ю. Скрипка, А.О. Собакарь, приділяючи увагу зазначеній темі, наголошують, що слід розкрити термін «бездоганна ділова репутація» як обов'язковий елемент кваліфікаційних вимог до осіб, які можуть бути призначеними на посаду відповідального за проведення фінансового моніторингу [8].

Як зазначає професор А.М. Колодій, правовий статус формують норми матеріального права, де встановлюються права й обов'язки учасників правовідносин [9, с. 169]. Наведене дає змогу стверджувати, що на законодавчому та теоретичному рівнях правовий статус розглядається як сукупність структурних елементів, які й визначають його зміст. На нашу думку, теоретичне та практичне розуміння правового статусу можна розглядати з різних сторін. Одні вчені-адміністративісти відносять до структури правового статусу суб'єктивні права й обов'язки суб'єкта права [10], інші додатково виокремлюють правосуб'єктність (правоздатність і дієздатність) [11]. Ми поділяємо думку перших щодо широкого розуміння змісту правового статусу та додатково відносимо до його структурних елементів свободи, законні інтереси й деліктну здатність. Однак правовий статус фізичних, юридичних осіб і суб'єктів владних повноважень $є$ різним за своєю природою та може змінюватись залежно від правовідносин, у яких суб'єкт права виступає стороною [12].

Звичайно, без системи фінансового моніторингу важко уявити стабільний, динамічний, цивілізований розвиток ринку фінансових послуг, однак є певні недоліки, які створює 
така система для учасників такого ринку. Зокрема, з позиції суб' єктів первісного фінансового моніторингу, організація системи фінансового моніторингу вимагає додаткових фінансових витрат: оплата праці відповідальної особи (якщо йдеться про фінансові установи, наприклад, комерційні банки, страхові компанії), організація ії робочого місця, впровадження механізмів фінансового моніторингу у функціонування інформаційних систем, що діють у межах окремих установ, підприємств, організацій. Загалом така система є ще однією, додатковою умовою здійснення державного контролю за функціонуванням означених установ, що збільшує тиск на їх діяльність у системі існування значної кількості перевіряючих та контролюючих органів. Також негативним елементом існування системи фінансового моніторингу, насамперед для фінансових установ, що надають депозитні послуги, є перешкоди щодо залучення значних сум фінансових ресурсів для здійснення активних операцій, які дозволяють отримати прибуток. Наприклад, залучення одного депозиту на значну суму дозволяє працівникам банківської установи швидше виконати поставлений план, фінансовій установі в цілому меншими витратами формувати капітал банку. Проте у таких випадках, не порушуючи чинне законодавство, така установа має перевірити джерело походження коштів, у разі виявлення порушень повідомити про це державні органи влади і не має право їх залучати до своєї діяльності. У такому випадку ця установа може і втратити фінансово спроможного клієнта, і не отримати коштів. Саме тому досить часто банківські працівники намагаються обійти норми чинного законодавства, пропонуючи легальні механізми залучення фінансових ресурсів до національної економіки [13, с. 53-54].

У 2018 році кількість повідомлень про фінансові операції, що були отримані та взяті на облік Держфінмоніторингом від небанківських установ в електронному вигляді, збільшилась порівняно з 2017 роком на 35,55\% та складає 99,72\% від загальної кількості повідомлень, взятих на облік Держфінмоніторингом від зазначеної категорії СПФМ. Серед небанківських установ найбільш активними у поданні повідомлень $є$ професійні учасники фондового ринку. Питома вага таких повідомлень у загальному обсязі взятих на облік повідомлень про фінансові операції, що надійшли до Держфінмоніторингу від небанківського сектору склала 46,65\% [4, с. 20 ].

Слід відмітити, що у 2018 році Держфінмоніторингом взято на облік 9969792 повідомлень про фінансові операції, що на 24,4\% більше, ніж у 2017 році [14, с. 20].

Динаміка отриманих повідомлень в розрізі суб'єктів первинного фінансового моніторингу показує, що Найбільш активними в системі звітування, в розрізі СПФМ, є банківські установи, які надсилають більшість повідомлень про операції, що підлягають фінансовому моніторингу. Протягом 2018 року від банківських установ взято на облік 99,02\% від загальної кількості повідомлень про фінансові операції (рис. 1).

Своєю чергою державний фінансовий моніторинг визначається як сукупність заходів, які здійснюються суб'єктами державного фінансового моніторингу, спрямованих на виконання вимог законодавства у сфері запобігання та протидії легалізації (відмиванню) доходів, одержаних злочинним шляхом, або фінансуванню тероризму.

Отже, враховуючи те, що система фінансового моніторингу покликана бути одним із регуляторів економічної безпеки України, фінансовий моніторинг слід розглядати не тільки в контексті заходів відповідних суб'єктів, а й як інструмент адміністративного впливу, який забезпечує гарантування національної безпеки.

Національний банк України в результаті перевірок банків 3 питань фінансового моніторингу в червні 2018 року оштрафував «Банк інвестицій та заощаджень» на 5 мільйонів гривень за здійснення ризикової діяльності. Нацбанк дав банку письмове попередження за надання недостовірної звітності, недоліки внутрішніх документів з питань фінансового моніторингу; порушення вимог щодо ідентифікації клієнтів, неналежне управління ризиками

ISSN 2521-6473

Правова позиція, № 3 (24), 2019 


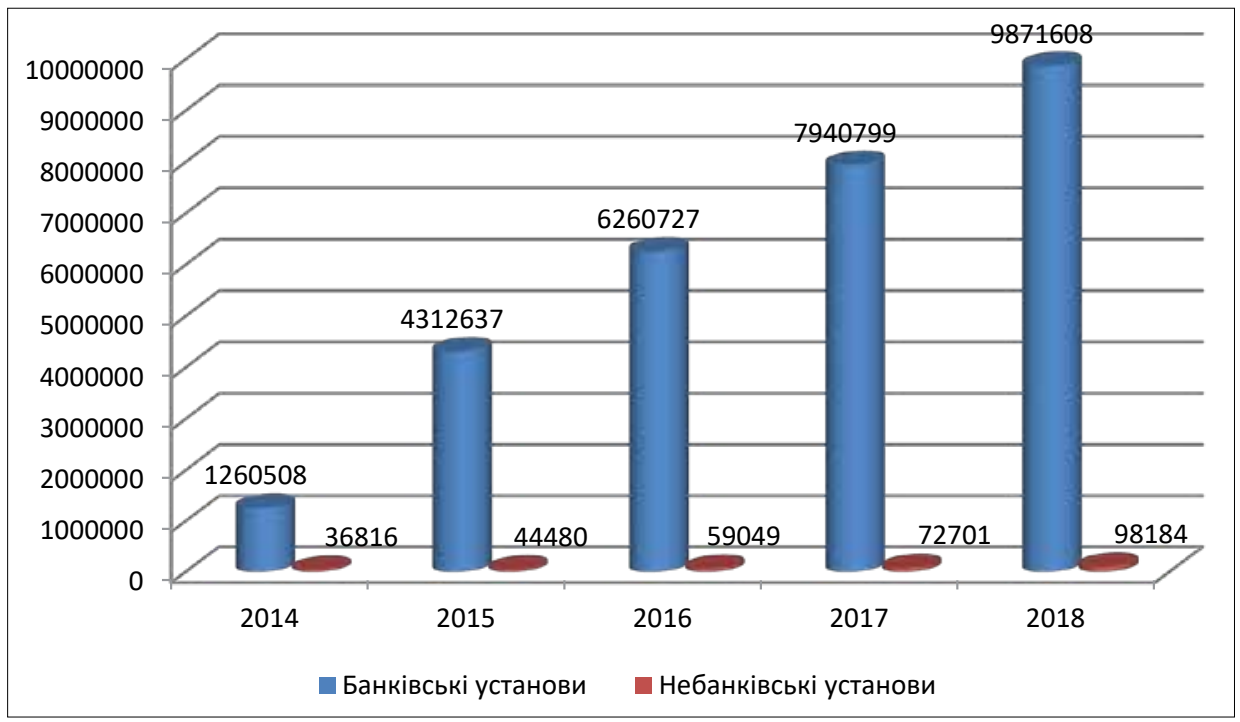

Рис. 1. Динаміка отриманих повідомлень в розрізі суб'єктів первинного фінансового моніторингу Джерело: побудовано авторами на основи даних [14]

та несвоєчасне повідомлення відповідальному працівнику банку про фінансові операції, що підлягають фінансовому моніторингу. Крім того, регулятор зажадав заміни голови правління банку та відповідального за фінансовий моніторинг працівника [15].

Висновки з дослідження і перспективи подальших розвиток у цьому напрямі. Отже, у межах статті розглянуто правовий статус відповідального працівника насамперед в забезпеченні безперервності процесу фінансового моніторингу і дотримання установою усіх вимог законодавства з запобігання легалізації (відмиванню) доходів, одержаних злочинним шляхом. Встановлено статусно-рольову структуру відповідального працівника - суб'єкта первинного фінансового моніторингу, що грунтується на відносинах: фінансова установа - відповідальний працівник - клієнт. Порушене питання вказує на те, що фінансова установа не може вплинути на потенційного клієнта інакше, аніж відмовитися від здійснення фінансової операції. Отже, уся система в масштабах країни має діяти бездоганно, оскільки клієнт, якому відмовлено в одній компанії, не повинен мати можливості здійснити таку фінансову операцію в іншій.

\section{Список використаних джерел:}

1. Про запобігання та протидію легалізації (відмиванню) доходів, одержаних злочинним шляхом, фінансуванню тероризму та фінансуванню розповсюдження зброї масового знищення» від 14 жовтня 2014 року № 1702-VII. Відомості Верховної Ради. 2014, № 50-51, ст.2057. Дата оновлення 24.11.2018.

2. Міжнародні стандарти 3 протидії відмиванню доходів та фінансуванню тероризму i розповсюдженню зброї масового знищення. URL: http://www.sdfm.gov.ua/content/file/Site docs/2012/22.03.2012/1.pdf.

3. Головко А.Т. Фінансовий моніторинг для небанківських фінансових установ. URL:https://forinsurer.com/public/04/06/03/1251.

4. Про затвердження Положення про здійснення фінансового моніторингу професійними учасниками ринку цінних паперів : Рішення Національної комісії з цінних паперів та фондового ринку від 17.03.2016 № 309. URL: https://zakon.rada.gov.ua/laws/show/z0551-16. 
5. Про затвердження Положення про здійснення фінансового моніторингу суб'єктами первинного фінансового моніторингу, державне регулювання та нагляд за діяльністю яких здійснює Міністерство інфраструктури України Наказ міністерства інфраструктури України 01.04.2013 № 199. URL: https://zakon.rada.gov.ua/laws/show/z0650-13/ed20130401/print.

6. Про внесення змін до Вимог до кваліфікації працівника суб'єкта первинного фінансового моніторингу, відповідального за проведення фінансового моніторингу у сфері запобігання та протидії легалізації (відмиванню) доходів, одержаних злочинним шляхом, і фінансуванню тероризму : Наказ Державного комітету фінансового моніторингу України від 15 жовт. 2009 р. № 147. Офіиіийний вісник України. 2009. № 101. Ст. 3559.

7. Гаєвський I.M. Координація антилегалізаційних заходів на рівні суб'єкта первинного фінансового моніторингу. Публічне право. 2015. № 3 (19). С. 157-163.

8. Комісаров О.Г., Скрипка О.Ю., Собакарь А.О. Первинний фінансовий моніторинг у сфері запобігання та протидії легалізації (відмиванню) доходів, одержаних злочинним шляхом, і фінансуванню тероризму : монографія. Дніпропетровськ, 2015. 184 с.

9. Колодій А.М., Олійник А.Ю. Права людини і громадянина в Україні : навч. посіб. Київ : Юрінком Інтер, 2003. 336 с.

10. Харитонова O.I. Адміністративно-правові відносини: концептуальні засади та правова природа : дис. ... докт. юрид. наук : 12.00.07. Одеська нац. юрид. академія, 2004. 435 с.

11. Великий енциклопедичний юридичний словник / за ред. Ю.С. Шемшученка. Київ : Юридична думка, 2007. 992 с.

12. Чумак О.О. Адміністративно-правовий статус державного виконавця. Публічне право. 2013. № 1. С. 107-113.

13. Дубина М.В. Роль системи фінансового моніторингу у розвитку ринку фінансових послуг. Проблеми теорії та методологї бухгалтерського обліку, контролю $і$ аналізу. 2015. Вип. 3 (33). С. 44-57.

14. Звіт Державної служби фінансового моніторингу України за 2018 рік URL: http://www.sdfm.gov.ua/content/file/Site_docs/2019/20190411/zvit_2018_ukr.pdf. (дата звернення 03.07.2019).

15. Детальніше читайте на УНIAH: URL: https://www.unian.ua/economics/ finance/10168181-nbu-oshtrafuvav-bank-investiciy-ta-zaoshchadzhen-za-rizikovu-diyalnist.html (дата звернення 23.07.2019). 
М. М. Потіп, кандидат юридичних наук, доцент, доцент кафедри цивільно-правових дисциплін ВНПЗ «Дніпровський гуманітарний університет»

\section{АКТ ЗАСТОСУВАННЯ ПРАВА ЯК ЗАСІБ ПУБЛІЧНОГО УПРАВЛІННЯ ТА ПРАВОВОГО РЕГУЛЮВАННЯ У СФЕРІ ПРИВАТИЗАЦЇ̈}

Статтю присвячено актуальним питанням, що виникають у сфері правозастосовної діяльності органів приватизаиії та місиевих рад, органів приватизації територіальних громад у сучасних умовах запровадження правил проведення приватизаційного процесу відповідно до Закону України «Про приватизачію державного $і$ комунального майна». У межах дослідження на підставі аналізу наукових конщепцій та правових норм визначено ознаки актів застосування права у сфері приватизації, що конкретизують суб'єктів, підстави та порядок їх прийняття, їх зміст та форму, роль у сфері публічного управління та правового регулювання суспільних відносин у иій сфері. Запропоновано авторське визначення акту застосування у сфері приватизаџї як персоніфікованого правового акту державних органів приватизачї чи місиевих рад, органів приватизаиії територіальних громад, прийнятого на основі юридичних фактів і норм права щчодо об 'єктів приватизаиії, який визначає права, обов 'язки або міру юридичної відповідальності покупиів та інших учасників приватизаційного процесу. Розглянуті, охарактеризовані та проілюстровані практичними прикладами види правозастосовних актів у сфері приватизаиії. Сформульовані відповідні пропозищї щуодо удосконалення Закону України «Про приватизачію державного і комунального майна» в частині конкретизаиії вимог до правозастосовних актів органів приватизації. Практична иінність дослідження полягає в тому, щчо отримані результати можуть бути використані в законотворчій діяльності, в адвокатській діяльності, а також під час викладання курсів з адміністративного права у начальних юридичних закладах України.

Ключові слова: акт застосування права, приватизачія, публічне управління, правове регулювання, органи приватизації, місиеві ради, органи приватизації територіальних громад, держсавне майно, комунальне майно.

M. M. Potip. Act of applying law as a means of public administration and legal regulation in the sphere of privatization

The article is devoted to topical issues that arise in the sphere of law enforcement activity of privatization bodies and local councils, bodies of privatization of territorial communities in modern conditions of implementation of rules of privatization process in accordance with the Law of Ukraine "On Privatization of State and Communal Property". Within the framework of the research, on the basis of the analysis of scientific concepts and legal norms, the signs of acts of application of the law in the sphere of privatization are specified, specifying the subjects, grounds and procedure for their adoption, their content and form, role in the sphere of public administration and legal regulation of public relations in this sphere. The author defines the act of applying in the sphere of privatization as a personalized legal act of state privatization bodies or local councils, bodies of privatization of territorial communities, adopted on the basis of legal facts and norms of law regarding the objects of privatization, which defines the rights, obligations or measure of legal liability of buyers. and other participants in the privatization process. Types of law enforcement acts in the sphere of privatization are considered, characterized and illustrated with practical examples. The corresponding proposals on improvement of the Law of Ukraine "On privatization of state and communal property" have been formulated in the part of specifying the requirements for the enforcement acts of the bodies of privatization. The practical value of the study is that the results obtained can be used in law-making, in law-making, as well as in teaching courses in administrative law in primary legal institutions of Ukraine.

Key words: act of application of law, privatization, public administration, legal regulation, privatization bodies, local councils, bodies of privatization of territorial communities, state property, communal property.

(C) М. М. Потіп, 2019 
Постановка проблеми. Приватизаційні процеси охопили Україну з моменту проголошення іiі незалежності: відбувалась приватизація житла, земельних ділянок, підприємств їх майна, об'єктів інфраструктури.

Починаючи з 1992 року по 2018 рік, в Україні було приватизовано більше 133 тисяч об'єктів: 29859 об'єктів державної форми власності та 103364 - об'єкти комунальної власності. Протягом 2018 року державну форму власності змінили 249 об'єктів приватизації [4], у січні-березні 2019 року - 126 об’єктів [1]. Загалом, на 2019 рік заплановано здійснити приватизацію 21 об’єкта великої приватизації державної власності [17] та 792 об'єктів малої приватизації [16].

Приватизаційний процес проходив з різним ступенем інтенсивності, а його результати $\epsilon$ суперечливими. Водночас кожен випадок проведення приватизації об'єкта права державної і комунальної власності є результатом правового регулювання суспільних відносин у цій сфері та правозастосовної діяльності суб’єктів публічного управління.

Аналіз останніх досліджень і публікацій. Поняття та ознаки «акту застосування права» чи «правозастосовного акту» як засобу публічного управління та правового регулювання суспільних відносин вивчали такі науковці, як Є.Г. Бобрешов, М.В. Кравчук, І.П. Голосніченко, Н.М. Крестовська, Т.С. Мартьянова, Р.С. Мельник, Л.Г. Матвєєва, С.М. Мельничук, О.В. Пунько, В.Д. Ткаченко, М.В. Цвік, Л.М. Шестопалова та інші. У сфері приватизації фрагментарно питання правозастосовної діяльності та правозастосовних актів у сфері приватизації здійснював О.Г. Розгон [26]. Водночас системно питання визначення ознак, змісту, поняття та видів актів застосування права як засобу публічного управління та правового регулювання у сфері приватизації не розглядалося.

Мета статті. У зв'язку із зазначеним метою статті $є$ з'ясування ознак актів застосування права у сфері приватизації, формулювання відповідного авторського поняття, здійснення характеристики найпоширеніших їх видів, а також визначення перспектив удосконалення правового регулювання правозастосовної діяльності органів приватизації.

Виклад основного матеріалу. Більшість науковців та практиків сходяться щодо змісту правозастосування чи правозастосовної діяльності. Так, В.Д. Цвік визначає застосування права як правову форму діяльності уповноважених на те органів держави і посадових осіб щодо реалізації приписів норм матеріального права відносно конкретних життєвих випадків шляхом винесення індивідуально конкретних рішень [27, с. 361]. Є.Г. Бобрешов пропонує категорію «правозастосування» розуміти як юридично цілісну, активну, творчу сукупність дій 3 реалізації права, що здійснюється чітко регламентованими повноважними органами (посадовими особами) державної влади в рамках формально закріплених процедурно-процесуальних форм, що спрямована на оформлення, кваліфікування і вирішення конкретних життєвих випадків в суспільних правовідносинах, що підлягають регулюванню та віднесені законом до компетенції таких органів. [2, с. 13]. Також цікавою є позиція Т.С. Мартьянової, яка під застосуванням права розуміє різновид управлінської діяльності, що вирізняється владним, підзаконним, творчим характером, має підвищену соціальну значущість і чинить виховну дію на суб' єктів правовідносин, у межах якої на основі норм права здійснюється індивідуально-правове регулювання [12, с. 10]. Конструктивно з цього приводу висловлюється С.М. Мельничук, який вважає, що з позицій адміністративного права, застосування норм права (видання ненормативних (індивідуальних) актів, видання актів застосування норм права (адміністративне розпорядництво) - основна форма публічного управління. Правозастосовна форма діяльності публічної адміністрації пов'язана з виконанням законодавчих та інших нормативних правових актів з метою застосування норми права до конкретних життєвих обставин, тобто в рамках цієї форми відбувається розгляд і вирішення індивідуальних справ [14]. В результаті правоза-

ISSN 2521-6473 
стосовної діяльності органів публічного управління приймаються відповідні правозастосовні акти, які науковцями розглядаються як частина механізму публічного управління та механізму регулювання суспільних відносин.

Правозастосовна діяльність безпосередньо пов'язана із змістом публічного управління. Як зазначає Р.С. Мельник, під публічним управлінням слід розуміти зовнішньо орієнтовану діяльність уповноважених суб'єктів, пов'язану із реалізацією політичних рішень та впровадженням у життя положень законів України [13, с. 13]. І.П. Голосніченко вважає, що механізм публічного управління складається з норм адміністративного права, адміністративно-правових відносин, актів тлумачення норм адміністративного права та актів реалізації адміністративно-правових норм та відносин [10, с. 14]. На наш погляд, механізм публічного управління тісно пов'язаний із механізмом адміністративно-правового регулювання через наявність спільних елементів.

Науковці у своїх дослідженнях демонструють різні підходи до структури механізму правового регулювання, водночас є значна група дослідників, що, поглиблюючи наукову думку в цьому напряму, відносять до цього механізму і правозастосовні акти. Так, Н.Н. Крестовська і Л.Г. Матвєєва пропонують до елементів механізму правового регулювання відносити: норми права; юридичний факт; акти безпосередньої реалізації права; акти застосування права [11, с. 354]. На думку Л.М. Шестопалової, елементами механізму правового регулювання є: а) норми права - основа механізму правового регулювання, оскільки з них, їхнього змісту, починається вплив права на суспільні відносини; б) правовідносини - суспільні відносини, що відбуваються у визначених нормами права межах; в) акти реалізації прав і обов'язків - дії суб'єктів щодо здійснення приписів правових норм; г) акти застосування права; г) законність; д) правосвідомість; е) правова культура [28, с. 157]. О.Г. Розгон під час дослідження механізму адміністративно-правового регулювання малої приватизації визначає серед його елементів також правозастосовні акти як його додатковий елемент [26]. 3 наведеного можна зробити поточний висновок, що правозастосовні акти є не обов'язковими, а додатковими елементами механізму публічного управління та механізму правового регулювання, проте за своїм змістом вони є незамінним засобом адміністративно-правового регулювання індивідуальних юридичних справ.

Розглянемо наукові концепції та підходи щодо визначення змісту правозастосовного акту. М.В. Кравчук наголошує, що правозастосовчий акт і нормативний акт мають багато спільного, але разом з тим суттєво відрізняються, тому що акт застосування норм права виступає як один із засобів державного керівництва і засіб вирішення юридичних справ, що виконує функції індивідуального регулювання поведінки суб'єктів в конкретних правових відносинах, видається у певній формі і передбаченому законом порядку, має юридичну силу і забезпечується відповідними засобами [9]. Як зазначає О.В. Пунько, акт застосування права, з одного боку, виступає засобом організації реалізації правових норм, а з іншого боку - засобом здійснення процесу управління, у чому і полягає його головна соціальна цінність. У ході правозастосовної діяльності органи правозастосування виступають суб' єктами управління; особи, відносно яких застосовується право, є об'єктами управління; а правозастосовні акти - засобами управління [25].

Необхідно зазначити, що, на думку М.В. Кравчука, правозастосовчий акт - це спосіб зовнішнього прояву формально-обов'язкового правила поведінки індивідуального характеру, яке підтверджує, встановлює, змінює або скасовує юридичні права і обов'язки персоніфікованих суб'єктів у конкретній життєвій ситуації [9, с. 165]. Таким чином, акт застосування права це правовий акт компетентного органу або посадової особи, прийнятий на основі юридичних фактів і норм права, який визначає права, обов'язки або міру юридичної відповідальності конкретних осіб. Діяльність правозастосовчих органів завершується оформленням відповідного 
акта, який фіксує прийняте рішення і надає йому офіційного значення і вольового характеру. Щодо конкретних осіб акт застосування права $є$ категоричним, обов'язковим до виконання велінням [9, с. 165].

О.В. Пунько наголошує, що доцільно підкреслити, що акти застосування права повинні і можуть вивчатися в різних аспектах: як самостійна правова категорія; юридичний засіб державного управління суспільством; одна 3 правових форм здійснення функцій держави; організаційна форма діяльності державних органів і окремих громадських організацій; найважливіший засіб реалізації юридичних норм; індивідуально визначені юридичні акти; спеціальний юридичний факт тощо. Вони виступають у різних формах зв'язків і відносин з іншими правовими явищами. Це зумовлює багатогранність і складність актів застосування та їх особливе призначення як в механізмі правового регулювання, так і в механізмі правозастосування. На думку О.В. Пунько, призначення правозастосовного акта в механізмі правозастосування полягає в наступному: 1) акт застосування права є юридичним засобом впливу на суспільні відносини; 2) акти застосування виступають як юридичні факти. Вони є елементом юридичного (фактичного) складу, причому елементом (фактом), який завершує вказаний склад. 3 винесенням цього акту виникає, змінюється чи припиняється правовідношення; 3) акт застосування це засіб конкретизації норм права. Права і обов'язки в конкретному обсязі «прив'язуються» до персонально визначених суб'єктів; 4) в актах застосування реально проявляється владність, примусовість права. В нормах права примус виступає в якості потенційного, можливого, а в правозастосовних актах примус набуває реального конкретного характеру, який звернений до конкретних суб'єктів; 5) за допомогою владних актів застосування забезпечується реалізація суб'єктивних прав у випадках виникнення яких-небудь перепон. Зобов'язана особа примушується до конкретних дій з метою забезпечення вимог норм права; 6) після прийняття правозастосовного акта настає період реалізації, виконання прийнятого рішення; 7) в актах застосування права втілюється індивідуалізований вплив компетентних органів на хід правового регулювання, індивідуальна регламентація суспільних відносин; 8) акт застосування права забезпечує «контакт» правової норми, що застосовується в конкретному випадку, з реальним суспільним буттям; 9) акт застосування (який включається в об'єктивну сторону), пов'язаний із суб'єктивною стороною, тому що в ньому відображається компетентність, професіоналізм особи, що застосовує право; 10) він виражає волю держави у вирішенні певних проблем тощо; 11) це документ, який формально закріплює рішення компетентного органу [25].

Особливостями правозастосовного акту, на думку М.В. Кравчука, є те, що: 1) його можуть приймати компетентні органи держави; 2) він має індивідуально визначений (персоніфікований) характер; 3) не може мати зворотної дії в часі; 4) має встановлену законом форму [9]. На наш погляд, наведені ознаки характерні також для правозастосовних актів у сфері приватизації.

Відповідно до ст. 12 «Порядок прийняття рішення про приватизацію» Закону України «Про приватизацію державного і комунального майна» рішення про приватизацію об'єкта, який включено до переліку об'єктів державної власності, що підлягають приватизації, приймається державними органами приватизації шляхом видання наказу, але не пізніше 30 днів з дня включення до переліку об’єктів, що підлягають приватизації, за винятком випадку, передбаченого частиною другою цієї статті. Опублікування інформації про прийняття рішення про приватизацію об'єкта здійснюється протягом п'яти робочих днів 3 дня видання державним органом приватизації відповідного наказу в офіційних друкованих виданнях державних органів приватизації, на офіційному вебсайті Фонду державного майна України [23].

Відповідно до Закону України від 18.01.2018 № 2269-VIII «Про приватизацію державного і комунального майна», який регулює правові, економічні та організаційні основи приватизації, у тому числі й комунального майна, приватизація (відчуження) майна, що перебуває у кому-

ISSN 2521-6473

Правова позиція, № 3 (24), 2019 
нальній власності, здійснюється органами місцевого самоврядування. Суб'єктами приватизації комунального майна є місцеві ради (сільські, селищні, міські ради), органи приватизації територіальних громад [3]. Закон України «Про місцеве самоврядування» у п. 30 ст. 26 визначає, що винятковою компетенцією сільських, селищних, міських рад у сфері приватизації є прийняття рішень щодо відчуження відповідно до закону комунального майна; затвердження місцевих програм приватизації, а також переліку об'єктів комунальної власності, які не підлягають приватизації; визначення доцільності, порядку та умов приватизації об'єктів права комунальної власності; вирішення питань про придбання в установленому законом порядку приватизованого майна, про включення до об'єктів комунальної власності майна, відчуженого у процесі приватизації, договір купівлі-продажу якого в установленому порядку розірвано або визнано недійсним [22]. Перелік об’єктів комунальної власності, що підлягають приватизації, ухвалюється місцевою радою. Опублікування інформації про прийняття рішення про приватизацію об’єкта комунальної власності здійснюється на офіційних сайтах місцевих рад та в електронній торговій системі протягом п’яти робочих днів 3 дня ухвалення місцевою радою рішення [15]. Таким чином, кожне рішення Фонду держмайна та його територіальних підрозділів і органів місцевого самоврядування щодо приватизації конкретного об'єкту оформляється відповідним наказом, який за своїм змістом є актом застосування права.

Для розгляду окремих видів правозастосовних актів у сфері приватизації слід навести їх класифікацію, розроблену М.В. Кравчуком. Цей науковець класифікує правозастосовні акти за такими критеріями: 1) за суб’єктами прийняття: а) акти державних органів (акти глави держави; суду, контрольно-наглядових органів, акти уповноважених органів громадських об'єднань; б) акти недержавних органів (рішення органів місцевого самоуправління); 2) за значенням: а) основні (вирок суду); б) допоміжні (готують видання основних, напр., постанова про притягнення особи в якості обвинуваченого); 3) за характером правового впливу: а) регулятивні (наказ про підвищення по службі); б) охоронні (постанова про відкриття кримінальної справи); 4) за формою: а) окремий документ (укази, вироки, рішення, накази тощо) - це юридична форма; б) резолюція на матеріалах справи; в) усна форма та письмова форма; 5) за характером юридичних наслідків: а) правоконстатуючі (правопідтверджуючі); б) правовстановлюючі; в) правозмінюючі; г) правоприпиняючі [9].

На наш погляд, з урахуванням наведеної класифікації правозастосовні акти у сфері приватизації можна характеризувати як акти державних органів (ФДМУ та його територіальних підрозділів) та акти органів місцевого самоврядування, які можуть бути як основними, так і допоміжними, як регулятивними так і охоронними, що оформлюються наказами та рішеннями у письмовій формі та мають переважно правозмінюючий характер юридичних наслідків.

Розглянемо деякі види правозастосовних актів у сфері приватизації. Наприклад, актами державних органів (ФДМУ та його територіальних підрозділів), що мають характер основних та регулятивних, оформлених у вигляді наказів, які мають правозмінюючий характер юридичних наслідків, є накази ФДМУ та його територіальних підрозділів про прийняття рішення про приватизацію конкретного об'єкту. Наприклад, Наказами регіонального відділення Фонду державного майна України по Львівській, Закарпатській та Волинській областях прийнято рішення про приватизацію об’ єкта державної власності: 1) від 12.08.2019 № 00535 - об’ єкта малої приватизації: окремого майна - адміністративної будівлі літ. «А-1»; 2 ) від 06.08.2019 № 00504 об’єктів малої приватизації державної власності: окремого майна - вбудовано-прибудованого приміщення загальною площею 656,6 кв. м; окремого майна - готелю «Світязь»; окремого майна - готелю «Лісова пісня» [6]. Наказами регіонального відділення Фонду державного майна України по Рівненській та Житомирській областях: від 05.08.2019 року № 75 та від 05.08.2019 року № 76 прийнято рішення про приватизацію двох об'єктів державної власності 
окремого майна - двох будинків відпочинку [5]. Наказом регіонального відділення Фонду державного майна України по Черкаській області від 05.08.2019 № 82-МП прийнято рішення про приватизацію об'єкта малої приватизації державної власності - Державне підприємство «Черкаський державний завод хімічних реактивів» [7]. Наказом Регіонального відділення Фонду державного майна України по Дніпропетровській, Запорізькій та Кіровоградській областях від 01.08.2019 №12/01-101-РП прийнято рішення про приватизацію шляхом продажу на аукціоні об'єкта державної власності - нежитлової будівлі [8], тощо.

Наступний вид правозастосовних актів $є$ допоміжними актами державних органів (ФДМУ та його територіальних підрозділів), оформлений наказами та рішеннями у письмовій формі, що мають охоронний характер та тягнуть за собою зміну прав та обов'язків суб'єктів, щодо яких вони прийняті.

Так, відповідно до п. 5.1. Положення про регіональне відділення Фонду державного майна України Регіональне відділення відповідно до покладених на нього завдань та в межах повноважень, делегованих Фондом, розриває контракти 3 керівниками державних підприємств, функції з управління майном яких передані в управління регіонального відділення [19]. Такі дії передбачені Типовою формою контракту з керівником підприємства, що є у державній власності, та Постановою Кабінету Міністрів України «Про застосування контрактної форми трудового договору з керівником підприємства, що є у державній власності» [24]. Водночас чинні нормативно-правові акти не конкретизують підстави розірвання такого контракту. Проте, спираючись на положення п.4.1.2. Наказу ФДМУ «Про затвердження Положення про порядок укладання або переукладання контракту з керівником виконавчого органу відкритого акціонерного товариства, холдингової компанії та державної акціонерної компанії і Типової форми контракту з керівником виконавчого органу відкритого акціонерного товариства» [18] можна вважати, що практика прийняття наказу ФДМУ про розірвання контракту та звільнення керівника виконавчого органу товариства пов'язана також із необхідністю забезпечення ефективної діяльності суб'єкта господарювання.

Ще одним прикладом охоронного правозастосовного акту є акт про невідповідність переможця аукціону вимогам ст. 8 або ч. 9 ст. 14 Закону України «Про приватизацію державного і комунального майна» або якщо учасник відмовився від протоколу або договору. Відповідно до п. 67 Порядку проведення електронних аукціонів для продажу об'єктів малої приватизації та визначення додаткових умов продажу у разі, коли переможець електронного аукціону не відповідає вимогам статті 8 Закону України «Про приватизацію державного і комунального майна», або в інших випадках, передбачених частиною дев'ятою статті 14 Закону України «Про приватизацію державного і комунального майна», орган приватизації завантажує рішення про відмову у затвердженні протоколу про результати електронного аукціону або про відмову від укладення договору купівлі-продажу в електронній торговій системі. Якщо переможець електронного аукціону відмовився від підписання протоколу про результати електронного аукціону або договору купівлі-продажу чи не підписав такий протокол або договір у встановлені строки, орган приватизації складає та завантажує відповідний акт в електронну торгову систему. Таким чином, на наш погляд, акт про невідповідність переможця аукціону вимогам ст. 8 або ч. 9 ст. 14 Закону України «Про приватизацію державного і комунального майна», спрямований на забезпечення результатів аукціону та укладення реального договору купівлі-продажу об'єкта малої приватизації, є також охоронним правозастосовним актом. Тому що у такому випадку в електронній торговій системі автоматично формується новий протокол про результати електронного аукціону з визначенням переможцем електронного аукціону учасника з наступною за величиною ціновою пропозицією, а у разі однакових цінових пропозицій - учасника, що подав іiї раніше, за умови, що ним зроблений щонайменше

ISSN 2521-6473

Правова позиція, № 3 (24), 2019 
один крок аукціону, та у разі відсутності належним чином оформленого листа (звернення) від такого учасника щодо повернення йому гарантійного внеску та відсутності факту натискання ним відповідної кнопки про відмову від очікування в особистому кабінеті. Переможець електронного аукціону, який відмовився від підписання протоколу про результати електронного аукціону або договору купівлі-продажу, позбавляється права на участь у подальших аукціонах з продажу того самого об'єкта [23; 20].

Охоронними правозастосовними актами ФДМУ є його рішення про притягнення до адміністративної відповідальності керівників уже приватизованого підприємства. Так, відповідно до ч. 5 ст. 29 Закону України «Про приватизацію державного і комунального майна», за недопущення працівників органів приватизації, протидію чи перешкоджання проведенню ними перевірки дотримання умов договору купівлі-продажу державного або комунального майна на керівника приватизованого підприємства накладається штраф у розмірі 1000 неоподатковуваних мінімумів доходів громадян за кожний встановлений факт. Факт недопущення працівників органів приватизації до проведення ними перевірки дотримання умов договору купівлі-продажу державного або комунального майна підтверджується складеним у присутності відповідних правоохоронних органів та підписаним працівниками державних органів приватизації актом про недопуск до проведення перевірки [21; 23]. Розглянуті види актів застосування права у сфері приватизації не представляють вичерпний їх перелік у цій сфері, проте дозволяють зробити висновки щодо їх особливостей.

Висновки 3 дослідження і перспективи подальших розвідок у цьому напрямі. В результаті проведеного аналізу наукових теорій та правових норм вважаємо, що наведена інформація дозволяє зробити висновок щодо видів правозастосовних актів у сфері приватизації. Так, на наш погляд, найчастіше у цій сфері використовуються акти застосування права таких видів: 1) за суб'єктами прийняття: а) акти державних органів (ФДМУ та його територіальних підрозділів); б) акти органів місцевого самоврядування; 2) за значенням: а) основні (про прийняття рішення про приватизацію); б) допоміжні (про невідповідність переможця аукціону вимогам законодавства); 3) за характером правового впливу: а) регулятивні (про прийняття рішення про приватизацію); б) охоронні (про притягнення до адміністративної відповідальності); 4) за формою: окремий документ (рішення, накази та ін.); 5) за характером юридичних наслідків: б) правовстановлюючі; в) правозмінюючі; г) правоприпиняючі.

Акти застосування права у сфері приватизації, на наш погляд, мають наступні ознаки, компіляція яких дозволить сформулювати їх визначення: 1) суб'єкти, що їх приймають, державні органи приватизації (ФДМУ та його територіальні підрозділи) та органи місцевого самоврядування; 2) грунтується на основі юридичних фактів і норм права; 3) приймається щодо об'єктів державної та комунальної власності, визначених у законному порядку об'єктами приватизації; 4) містить формально-обов'язкові правила поведінки індивідуального характеру покупців та інших учасників приватизаційного процесу; 5) визначає права, обов'язки або міру юридичної відповідальності зазначених у ньому осіб; 6) виступає засобом організації реалізації правових норм та засобом здійснення процесу управління; 7) виражає волю держави у вирішенні проблем у сфері приватизації; 8) має індивідуально визначений (персоніфікований) характер; 9) не має зворотної дії в часі; 10) має встановлену законом форму - наказ, рішення.

3 урахуванням зазначених ознак вважаємо за можливе визначити акт застосування у сфері приватизації як персоніфікований правовий акт державних органів приватизації чи місцевих рад, органів приватизації територіальних громад, прийнятий на основі юридичних фактів і норм права щодо об'єктів приватизації, який визначає права, обов'язки або міру юридичної відповідальності покупців та інших учасників приватизаційного процесу. 
Зазначеним визначенням пропонуємо доповнити статті 1 Закону України «Про приватизацію державного і комунального майна», а перелік та загальні вимоги до актів застосування права у сфері приватизації визначити у частині 6 статті 7 цього закону. Реалізація запропонованих змін, на наш погляд, дозволить систематизувати правозастосовну діяльність органів приватизації та підвищить рівень прозорості у цій сфері.

\section{Список використаних джерел:}

1. Аналітична довідка про роботу Фонду державного майна Україні та хід приватизації державного майна у 1 кварталі 2019 року. URL: http://www.spfu.gov.ua/userfiles/pdf/ikvartal-2019_13845.pdf

2. Бобрешов С.Г. Судове правозастосування в Україні: проблеми теорії і практики : автореф. дис. ... канд. юрид. наук : 12.00.01. Київ. 2011. 2 с.

3. Вступив у дію новий закон про приватизацію державного і комунального майна: АМУ роз'яснює, як діяти органам місцевого самоврядування. URL: https://auc.org.ua/novyna/vstupyvv-diyu-novyy-zakon-pro-pryvatyzaciyu-derzhavnogo-i-komunalnogo-mayna-amu-rozyasnyuye.

4. Звіт про роботу Фонду Державного майна України (ФДМУ) та хід приватизації державного майна у 2018 році. URL: http://www.spfu.gov.ua/userfiles/pdf/zvit-2018-final_13714.pdf.

5. Інформація регіонального відділення по Рівненській та Житомирській областях про прийняття рішення про приватизацію. URL: http://www.spfu.gov.ua/ru/documents/press-list/ to-privatization/14025.html.

6. Інформація регіонального відділення по Львівській, Закарпатській та Волинській областях про прийняття рішення про приватизацію. URL: http://www.spfu.gov.ua/ru/documents/ press-list/to-privatization/14040.html.

7. Інформація регіонального відділення по Черкаській області про прийняття рішення про приватизацію. URL: http://www.spfu.gov.ua/ru/documents/press-list/to-privatization/14027.html.

8. Інформація регіонального відділення Фонду державного майна України по Дніпропетровській, Запорізькій та Кіровоградській областях про прийняття рішення про приватизацію. URL: http://www.spfu.gov.ua/ru/documents/press-list/to-privatization/14010.html.

9. Кравчук М.В. Теорія держави і права. Проблеми теорії держави і права: Навчальний посібник. 3-тє вид. змін. й доп. Тернопіль : Карт-бланш. 2002. 247 с.

10. Голосніченко І.П. Адміністративне право України (основні категорії та поняття) : посібник. Ірпінь, 1998. 108 с.

11. Крестовська Н.М., Матвєєва Л.Г. Теорія держави і права: Елементарний курс. Видання друге. Харків : ТОВ «Одіссей», 2008. 432 с.

12. Мартьянова Т.С. Розсуд суб'єктів правозастосовної діяльності : автореф. дис. ... канд. юрид. наук : спец. 12.00.01. Львів, 2013. 23 с.

13. Мельник Р.С. Категорія «публічне управління» у новій інтерпретації. Адміністративне право і процес. 2013. № 1 (3). С. 8-14

14. Мельничук С.М. Правозастосовна форма здійснення функцій держави та публічне адміністрування: взаємозв'язок змісту правових категорій Серія ПРАВО. Випуск 35. Частина I. Toм 1. URL: https://webcache.googleusercontent.com/search?q=cache:v9VpN0scY54J:https:// dspace.uzhnu.edu.ua/jspui/bitstream/lib/15162/1/\%25D0\%259F\%25D0\%25A0\%25\%25D0\%25AF. $\mathrm{pdf}+\& \mathrm{~cd}=6 \& \mathrm{hl}=\mathrm{ru} \& \mathrm{ct}=\mathrm{clnk} \& \mathrm{gl}=$ ua.

15. Нюанси приватизації комунального майна (частина 1) // Місцеве самоврядування. Липень. 2018. №7. URL: https://i.factor.ua/ukr/journals/ms/2018/july/issue-7/article-37820.html.

16. Про внесення змін до наказу Фонду державного майна України від 27.12.2018 № 1637 «Про затвердження переліків об’єктів малої приватизації, що підлягають приватизації 
в 2019 році» (із змінами): Наказ Фонду Державного майна України № 644 від 02.07.2019. URL: http://www.spfu.gov.ua/userfiles/files/nakaz_n0644_vid_020719.pdf.

17. Про затвердження переліку об'єктів великої приватизації державної власності: розпорядження Кабінету Міністрів України від 16 січня 2019 p. № 36-p. URL: https://www.kmu. gov.ua/ua/npas/pro-zatverdzhennya-pereliku-obyektiv-velikoyi-privatizaciyi-derzhavnoyi-vlasnosti.

18. Про затвердження Положення про порядок укладання або переукладання контракту 3 керівником виконавчого органу відкритого акціонерного товариства, холдингової компанії та державної акціонерної компанії і Типової форми контракту з керівником виконавчого органу відкритого акціонерного товариства: Наказ Фонду державного майна України від 05.04.2004. N 662. URL: https://zakon.rada.gov.ua/laws/show/z0901-04.

19. Про затвердження Положення про регіональне відділення Фонду державного майна України та Положення про представництво Фонду державного майна України в районі, місті: Наказ Фонду державного майна України від 15.05.2012 № 678. Офіщійний вісник Украӥни від 27.06.2012. 2012 p. № 47. стор. 162. стаття 1867. код акта 62143/2012.

20. Про затвердження порядку проведення електронних аукціонів для продажу об'єктів малої приватизації та визначення додаткових умов продажу: Постанова КМУ від 10 травня 2018 p. № 432 Урядовий кур’єр від 06.06.2018. № 10. URL: http://www.spfu.gov.ua/ua/ documents/4497.html.

21. Про затвердження форми акта про недопуск до проведення перевірки дотримання умов договору купівлі-продажу державного (комунального) майна: Наказ Фонду державного майна України від 06.04.2018 № 487. Офічійний вісник України від 15.05.2018. 2018 р. № 37. стор. 681. стаття 1340. код акта 90084/2018.

22. Про місцеве самоврядування в Україні: Закон України від 21 травня 1997 року № 280/97-ВР. Урядовий кур'єр від 14.06.1997

23. Про приватизацію державного і комунального майна: Закон України від 18 січня 2018 року № 2269-VIII. Відомості Верховної Ради України від 23.03.2018. 2018 р. № 12. стор. 5. стаття 68

24. Про Типову форму контракту 3 керівником підприємства, що $є$ у державній власності: постанова Кабінету Міністрів України від 2 серпня 1995 р. № 597. URL: https://zakon.rada.gov.ua/laws/show/597-95-\%D0\%BF/print.

25. Пунько О.В. Функції правозастосовних актів. Науковий вісник Дніпропетровського державного університету внутрішніх справ. 2015. № 2. C. 106-111. URL: http://nbuv.gov.ua/ UJRN/Nvdduvs_2015_2_15.

26. Розгон О.Г. Адміністративно-правове регулювання малої приватизації в Україні : автореф. дис. ... канд. юрид. наук : 12.00.01. Дніпро, 2011. 22 с.

27. Цвік М.В., Ткаченко В.Д., Богачова Л.Л. та ін. Загальна теорія держави i права : підручник для студентів юридичних спеціальностей вищих навчальних закладів. / За ред. М.В. Цвіка, В.Д. Ткаченка, О.В. Петришина. Харків : Право, 2002. 432 с.

28. Шестопалова Л.М. Теорія держави і права : навч. посіб. Київ : Прецедент, 2006. 197 с. 
УДК 342.951:351.74

DOI https://doi.org/10.32836/2521-6473-2019-3-65-70

\author{
О. М. Правоторова, доктор юридичних наук, \\ доцент, професор кафедри адміністративного і \\ господарського права та правоохоронної діяльності \\ Херсонського державного університету
}

\title{
ОСОБЛИВОСТІ ЕФЕКТИВНОСТІ АДМІНІСТРАТИВНО-ПРАВОВОЇ ОХОРОНИ
}

У статті на основі чинного законодавства та думок на чю проблематику вчених в галузі адміністративного права досліджено особливості ефективності адміністративно-правової охорони.

Невпинний розвиток суспільних відносин в адміністративному праві, удосконалення сучасних технологій, а також формування інформаційного суспільства, не могли не вплинути на стан ефективності сучасної адміністративно-правової охорони. Автор констатує, щчо ефективність адміністративно-правової охорони є невіддільним елементом теорії і практики такої охорони.

Ефективність адміністративно-правової охорони - ие уміння публічної адміністраиії на основі норм адміністративного права якісно та своєчасно відновлювати порушені права, свободи й законні інтереси невладних фізичних і юридичних осіб, публічний інтерес держави та суспільства.

Адміністративно-правова охорона існуе через систему адміністративно-правових норм, одночасно доведено, що вона не може з погляду гносеології права існувати в таких вузьких рамках, визначених державою, вона відображає об'єктивні суспільні відносини, захищає найбільш важливі иінності, які в певний відрізок часу можуть ще не знайти формального оформлення в джерелах адміністративного права, забезпечується на основі адміністративно-правових норм й одночасно регулюється нормами адміністративного права, які встановлюються не тільки державою, хоча нею насамперед.

Сформовано чотири рівні ефективності адміністративно-правової охорони: достатній, коли закладені в нормативно-правових актах завдання публічної адміністрації щзодо відновлення порушених прав невладних осіб загалом виконуються; недостатній, що характеризується частими випадками невідновлення порушених прав та свобод людини і громадянина, але такими, щзо не характеризуються системністю; кризовий, коли виникають системні порушення прав, свобод і законних інтересів фізичних та юридичних осіб, вони не отримують від держави через опосередковану діяльність публічної адміністрачї захисту, а незадоволеність громадян набуває значного соиіального вагомого протесту; неефективний, коли порушені права і свободи та законні інтереси фізичних і юридичних осіб практично не відновлюються, а корупиія наповнює правоохоронну систему, при иьвому норми адміністративно-правової охорони змінюють свою гуманну і справедливу сутність та самі стають чинниками дестабілізаиї суспільних відносин.

Ключові слова: відповідальність, адміністративно-правова охорона, загроза, законодавство, національна безпека, суспільні відносини, адміністративно-правовий захист, публічна адміністрація, адміністративно-правові відносини.

\section{O. M. Pravotorova. Features of effectiveness of administrative legal protection}

In the article, the key aspects of the effectiveness of administrative and legal protection are researched on the basis of current legislation and opinions on this issue of scholars in the field of administrative law.

The author notes that administrative-legal protection is an institution of administrative law consisting of uniform rules of administrative law whose legal effect is directed at the prevention of offenses (crime prevention) and the restoration of violated rights, freedoms and legal interests of individuals and juridical persons carried out for using administrative tools - forms of administrative activity of public administration, administrative coercion and administrative enforcement.

The steady development of social relations in administrative law, the improvement of modern technologies, as well as the formation of an information society, could not but affect the state of efficiency of modern

(C) О. М. Правоторова, 2019

ISSN 2521-6473

Правова позиція, № 3 (24), 2019 
administrative and legal protection. The author states that the effectiveness of administrative and legal protection is an integral part of the theory and practice of such protection.

Effectiveness of administrative and legal protection is the ability of public administration based on the norms of administrative law to qualitatively and timely restore violated rights, freedoms and legitimate interests of non-authorized individuals and legal entities, public interest of the state and society.

Four levels of effectiveness of administrative and legal protection have been formed: sufficient, when the tasks of the public administration in restoration of violated rights of non-authorized persons are generally fulfilled in the normative-legal acts; insufficient, characterized by frequent cases of non-renewal of violated rights and freedoms of man and citizen, but not characterized by systematic; crisis, when there are systematic violations of rights, freedoms and legitimate interests of individuals and legal entities, they do not receive from the state through the indirect activity of the public administration of protection, and dissatisfaction of citizens acquires a significant social weighty protest; is ineffective when the violated rights and freedoms and legitimate interests of individuals and legal entities are practically not restored, and the law-enforcement system is full of corruption, while the norms of administrative-legal protection change their humane and fair essence and themselves become factors of the destabilization of social relations.

It is concluded that administrative-legal protection exists through a system of administrative-legal norms, and at the same time it is proved that it cannot, from the point of view of epistemology of law, exist in such narrow limits as the state determines, it reflects objective social relations, protects the most important values, Which during this period of time may not yet find the formal registration in the sources of administrative law, is provided on the basis of administrative law and simultaneously governed by the norms of administrative law, which will establish not only the state, although it primarily.

Four levels of effectiveness of administrative and legal protection have been formed: sufficient, when the tasks of public administration set forth in normative legal acts in relation to the restoration of violated rights of non-authorities as a whole are fulfilled; insufficient, characterized by non-isolated cases, not the restoration of violated rights and freedoms of man and citizen, but not characterized by systematic; crisis, when there are systematic violations of rights, freedoms and legitimate interests of individuals and legal entities, they do not receive protection from the state through the indirect activity of the public administration; the dissatisfaction of citizens acquires significant social protest; is ineffective when the violated rights and freedoms and legitimate interests of individuals and legal entities are practically not restored, and corruption penetrates the law-enforcement system, while the norms of administrative-legal protection change their humane and fair essence and they themselves become factors of destabilization of social relations.

Key words: responsibility, administrative and legal protection, threat, legislation, national security, public relations, administrative and legal protection, public administration, administrative-legal relations, administration.

Постановка проблеми. Людська цивілізація розвивається в глобалізованому та урбанізованому світі в умовах інформаційного суспільства. Наша держава Україна не може бути осторонь цих світових процесів, вона обрала вектором свого розвитку прямування до європейської спільноти, європейських цінностей, а також прагне стати правовою державою з громадянським суспільством. Ефективної адміністративно-правової охорони потребують життя, честь, гідність громадян, здоров’я, громадський порядок, державний кордон, природа, флора і фауна, культурна спадщина тощо (ось лише невеликий перелік цінностей, які потребують створення належних умов у цьому напряму).

Аналіз останніх досліджень і публікацій. Багато вчених з різних галузей права розглядали у своїх працях ті чи інші аспекти правової охорони взагалі, а також адміністративно-правової охорони зокрема. Також деякою мірою їх цікавили питання ефективності адміністративно-правової охорони. Однак вони зазвичай зазначали про необхідність реформування правової бази, створення нових засобів щодо адміністративно-правової охорони саме своєї суспільної цінності (право власності - В. Галунько, право інтелектуальної власності - С. Юркова, право на підприємницьку діяльність - С. Сідак, атмосферне повітря - С. Ворушило, тваринний світ - В. Книш, громадський порядок - М. Лошицький, В. Цикалевич, право на комп'ютерні програми - Р. Саунін та ін., цей перелік можна ще досить довго продовжувати). Проте дієва 
теорія адміністративно-правової охорони, її новітня модель, сучасне концептуальне бачення до цього часу так і не отримали свого наукового втілення.

Мета статті (постановка завдання). У статті на основі чинного законодавства та думок на цю проблематику вчених в галузі адміністративного права буде досліджено ключові аспекти ефективності адміністративно-правової охорони.

Виклад основного матеріалу. Адміністративно-правова охорона має бути ефективною. Оскільки публічна адміністрація в переважній кількості утримується за рахунок бюджетних коштів, відповідно, громадяни мають право питати 3 держави, як вони витрачаються, як іiі органи і посадові особи відновлюють порушені права, свободи та законні інтереси людини і громадянина. Адже реалізація права означає його дійсність і ефективність. Ці два фундаментальні аспекти імперативно вимагають точності, виняткового професіоналізму діяльності публічної адміністрації, з одного боку, і одночасно - досконалих юридичних стандартів, що ведуть до повного уникнення нерівності для однорідних суб'єктів права [1].

Тим самим, на наше глибоке переконання, ефективність адміністративно-правової охорони є невіддільним елементом теорії і практики такої охорони.

Слід зазначити, що адміністративно-правова охорона - це інститут адміністративного права, що складається з однорідних норм адміністративного права, правовий вплив яких спрямовано на попередження правопорушень (профілактику злочинів) та відновлення порушених прав, свобод та законних інтересів фізичних і юридичних осіб, що здійснюються за допомогою адміністративного інструментарію - форм адміністративної діяльності публічної адміністрації, засобів адміністративного примусу та адміністративних процедур.

Слово «ефективність» походить від латинського слова “effectus” (виконання, дія), що означало «результат, наслідок до.-л. причин, дій», можна стверджувати, що ефективний - це той, що дає ефект, приводить до потрібних результатів, звідси ефективність - це результативність; таким чином, критерій ефективності - це мірило результативності цілеспрямованої [2]. Згідно $з$ тлумачним словником української мови «ефективний» - це той, який призводить до потрібних результатів, наслідків, дає найбільший ефект [3].

Класик західної правової думки Е. Алотт (анг. Anthony Allot) у своїй праці «Ефективність законів» сформував відповідну теорію. Він стверджує, що закон на практиці має вирішувати своє перше завдання - забезпечувати ефективність. Це він обгрунтовує такими чинниками: правова система є цілеспрямованою системою, яка існує в суспільстві. Закони приймаються тими, хто має владу чи вплив у суспільстві. Метою законів $\epsilon$ регулювання або формування поведінки членів суспільства шляхом визначення, що дозволено або заборонено, і шляхом надання їм можливості через встановлення інститутів та процесів. Тому саму ефективність функціонування суспільства слід розглядати через ефективність законів (конкретних положень правової системи), наскільки вона реалізує свої цілі, тобто виконує їх [4].

Інший західний учений А. Макфарлейн вважає, що ефективність права має в свій основі питання ефективності захисту права економічної власності. Похідним від цього $є$ ефективна правова охорона працівників. Першим критерієм ефективності $є$ наявність самого закону, який захищає певне право правовими нормами. При цьому вчений звертає увагу, що в корумпованих державах громадяни бояться і ненавидять закон, оскільки вони зазвичай не захищають, а порушують їх права [5].

Професор конституційного й адміністративного права з Нідерландів В. Воєрманс вважає, що в сучасному суспільстві ліберальної демократії суспільні відносини все більше контролюються законом. Це посилення схильності до закону збігається з подіями, в яких правова держава та формування права більше не виникають лише в межах національної держави. Він вважає, що в наші дні ми живемо в багаторівневих юрисдикціях. Значна частина права

ISSN 2521-6473

Правова позиція, № 3 (24), 2019 
встановлюється установами Європейського Союзу, Радою Європи. Закон також усе більше закріплюється в конвенціях та угодах. Це все результат навмисних і обгрунтованих кроків, прийнятих у кожному окремому випадку. Проте кінцевий результат цієї зростаючої залежності від права в поєднанні із збільшенням законів, формуванням законодавства та управлінням недержавними джерелами викликає напругу та породжує фундаментальні питання.

Учений звертає увагу на програму «Легітимізація та ефективність у сфері права та управління у світі різнорівневих юрисдикцій» (LELG) Насправді вона не $\epsilon$ новою програмою, а продовженням попередньої програми досліджень 3 додаванням певних акцентів. Програма LELG здійснювалася в рамках підпрограми Trias Europea (2003-2015 pp.) Дослідницької програми «Забезпечення верховенства права у світі багаторівневих юрисдикцій» (далі - MLJ). Trias Europea розглянув інституційні відносини та баланс між офіційними повноваженнями у відносинах між Нідерландами та СС та інституціями СС. У останні роки (2009-2014рр.) це дослідження продемонструвало, як проблеми в СС усе частіше вирішувалися чи зникали з використанням закону та, зокрема, транснаціонального права. Програма Trias Europea ілюструвала не тільки благословення посиленого ставлення до закону, але також виявило помилки, прогалини та дилеми в побудові багаторівневих юрисдикцій [6].

На думку професора В. Завальнюка, проблема ефективності права залишається актуальною для будь-якої держави на планеті поки існує законодавство і його норми, а суспільне життя регламентується шляхом видання правових актів і контролю за їх реалізацією. Безперечно, абсолютна ефективність усіх наявних у державі правових норм є соціальним та правовим ідеалом, досягнення якого навряд чи є можливим у доступному для огляду майбутньому. Однак складність досягнення такого ідеалу підкреслює необхідність наукового осмислення і пошуку шляхів його реалізації в окремо взятому суспільстві в конкретний історичний період. Особливо це важливо в умовах різких соціальних змін, переломних і кризових явищ, які останніми десятиліттями переживає українська держава.

Ефективність правового регулювання є одним з найбільш значущих показників у праві. На жаль, останніми роками вчені-юристи нечасто звертаються до питань ефективності права. Тим часом неефективне регулювання в принципі позбавлене сенсу: потрібно всіма способами намагатися і на рівні правотворчості, і на рівні правореалізації сприяти виробленню дієвих, ефективних механізмів правового впливу. Масштабні катастрофічні події минулого століття довели реальність шкоди, що завдається людині внаслідок тотального контролю з боку влади, спроби держави регулювати не тільки соціальну поведінку, а й внутрішнє, духовне життя людини. Завдану шкоду ілюструє те, що ефективність права може мати й антиправовий характер і навіть суперечити головній меті самого права - реалізації принципів справедливості та гуманізму в суспільному житті [7].

Вітчизняні вчені в галузі соціології права слушно зазначають, що проблема ефективності $є$ ключовою проблемою функціонування будь-якого соціального інституту. Право в цьому сенсі не $\epsilon$ винятком. Від рівня соціальної ефективності залежить його життєздатність і функціональна повноцінність. У своїй загальній формі ефективність як соціальне явище відбиває співвідношення між людською діяльністю та ії наслідками. Слід наголосити на основоположній ролі в кожному політично і соціально розвиненому суспільстві природного права (право на життя, свободу, безпеку, власність тощо). Воно є відбиттям природних принципів і норм взаємин між людьми, а також між людьми і державою. Ці принципи і норми в своїй основі незмінні і абсолютні, вони існують незалежно від держави і в той же час охороняються нею. Саме вони є підгрунтям юридичних норм і виконують стосовно них функцію об'єктивних вимог, яким вони мають відповідати. Оскільки природне право пов'язане з природними, а також з основоположними соціальними якостями людини і виступає як фундаментальна 
риса іiі життєвого процесу, то поняття «ефективність» до нього непридатне, як непридатне воно, наприклад, до таких понять, як «життя» або «здоров’я» [8].

Важливе значення мають також чотири рівні ефективності адміністративно-правової охорони: достатній, коли закладені в нормативно-правових актах завдання публічної адміністрації щодо відновлення порушених прав невладних осіб загалом виконуються; недостатній, що характеризується частими випадками невідновлення порушених прав та свобод людини і громадянина, але такими, що не характеризуються системністю; кризовий, коли виникають системні порушення прав, свобод і законних інтересів фізичних та юридичних осіб, вони не отримують від держави через опосередковану діяльність публічної адміністрації захисту, а незадоволеність громадян набуває значного соціального вагомого протесту; неефективний, коли порушені права і свободи та законні інтереси фізичних і юридичних осіб практично не відновлюються, а корупція наповнює правоохоронну систему, при цьому норми адміністративно-правової охорони змінюють свою гуманну і справедливу сутність та самі стають чинниками дестабілізації суспільних відносин.

Висновки з дослідження і перспективи подальших розвідок у цьому напрямі. У своїй загальній формі ефективність адміністративно-правової охорони як соціальне явище відображає співвідношення між метою діяльності публічної адміністрації в цій сфері та результатами, досягнутими щодо відновлення порушених прав, свобод та законних інтересів фізичних і юридичних осіб. Об'єктивно ефективність адміністративно-правової охорони є оціночною категорією адміністративного права.

Ефективність адміністративно-правової охорони має два рівні: перший - ефективність норм адміністративного права, які врегульовують суспільні відносини в аналізованій сфері, ефективність охоронного законодавства; другий рівень - ефективність адміністративної діяльності публічної адміністрації щодо реального відновлення порушених прав, свобод та законних інтересів фізичних і юридичних осіб. При цьому перший рівень має абстрактний характер і завжди має перевірятися на практиці другим рівнем як відносно об'єктивним критерієм істини.

Слід підсумувати, що ефективність адміністративно-правової охорони - це уміння публічної адміністрації на основі норм адміністративного права якісно та своєчасно відновлювати порушені права, свободи й законні інтереси невладних фізичних і юридичних осіб, публічний інтерес держави та суспільства.

Адміністративно-правова охорона існує через систему адміністративно-правових норм, одночасно доведено, що вона не може з погляду гносеології права існувати в таких вузьких рамках, визначених державою, вона відображає об'єктивні суспільні відносини, захищає найбільш важливі цінності, які в певний відрізок часу можуть ще не знайти формального оформлення в джерелах адміністративного права, забезпечується на основі адміністративно-правових норм й одночасно регулюється нормами адміністративного права, які встановлюються не тільки державою, хоча нею насамперед.

Сформовано чотири рівні ефективності адміністративно-правової охорони: достатній, коли закладені в нормативно-правових актах завдання публічної адміністрації щодо відновлення порушених прав невладних осіб загалом виконуються; недостатній, що характеризується частими випадками невідновлення порушених прав та свобод людини і громадянина, але такими, що не характеризуються системністю; кризовий, коли виникають системні порушення прав, свобод і законних інтересів фізичних та юридичних осіб, вони не отримують від держави через опосередковану діяльність публічної адміністрації захисту, а незадоволеність громадян набуває значного соціального вагомого протесту; неефективний, коли порушені права і свободи та законні інтереси фізичних і юридичних осіб практично не відновлюються, а корупція наповнює правоохоронну систему, при цьому норми адміністративно-правової охорони змінюють свою гуманну і справедливу сутність та самі стають чинниками дестабілізації суспільних відносин.

ISSN 2521-6473

Правова позиція, № 3 (24), 2019 


\section{Список використаних джерел:}

1. Răzvan N. The validity and effectiveness of law. Series VII: Social Sciences Law Vol. 8 (57) No. 1. 2015. C. UURL: http://webbut.unitbv.ro/bulletin/Series\%20VII/BULETIN\%20I\%20PDF/20_ Bujdoiu-RN.pdf.

2. Варданянц Г. Ефективність права. Соціологічна теорія права. 2007. URL: http://socio.125mb.com/effektivnost-prava-17415.html.

3. Яременко В., Сліпушко О. Новий словник української мови в 3-х т. Київ : Аконіт. 2008. $928 \mathrm{c}$.

4. Allot A. The Effectiveness of Laws. Valparaiso University Law Review. 1981. URL: http://scholar.valpo.edu/cgi/viewcontent.cgi?article=1579\&context=vulr.

5. Macfarlane A. What makes Law Effective?. Times Higher Education Supplement. 2005. URL: http://www.alanmacfarlane.com/TEXTS/law_effective.pdf.

6. Voermans W. The Legitimacy and Effectiveness of Law \& Governance in a World of Multilevel Jurisdictions. 2003. URL: http://media.leidenuniv.nl/legacy/english-version-onderzoeksprogrammalegitimiteit-en-effectiviteit-van-recht-en-bestuur-november-2014-(2)-(3).pdf.

7. Завальнюк В.В. Ефективність права: антропологічний та євроінтеграційний аспекти. LEX PORTUS.'2017. № 1(3). С. 39-49.

8. Герасіна Л. Методологічні засади вивчення соціальної ефективності права. Соціологія права. 2003. URL: http://radnuk.info/pidrychnuku/sotsiologiya/505-panova/10900--4-----41------.html. 
УДК 342.9

DOI https://doi.org/10.32836/2521-6473-2019-3-71-78

Т. М. Савченко, здобувач

Донецького юридичного інституту МВС України

\section{СИСТЕМА СУБ'ЄКТІВ АДМІНІСТРАТИВНО-ПРАВОВОГО РЕГУЛЮВАННЯ В ГАЛУЗІ МИСЛИВСЬКОГО ГОСПОДАРСТВА ТА ПОЛЮВАННЯ}

У статті досліджується стан законодавчого закріплення системи суб'єктів адміністративно-правового регулювання в галузі мисливського господарства та полювання, особливості розмежування їхніх повноважень, основні проблеми системи та можливі шляхи їх вирішення. Особлива увага приділена питанню участі громадськості в регулюванні зазначеної сфери. Наголотено, що залучення громадськості до управління державними справами вважається одним із основоположних приниипів забезпечення демократичного розвитку суспільства, який сприяє налагодженню системного діалогу між органами влади і громадськістю, підвищенню якості підготовки та прийняття рішень з важливих питань державного і суспільного розвитку, створення умов гласності, відкритості і прозорості в діяльності органів влади. Визначено, що суб'єктом державного регулювання у сфері мисливського господарства законодавець визнає і громадські організаиії мисливиів, зазначаючи, що з метою задоволення свойх законних інтересів у здійсненні полювання, сприяння веденню мисливського господарства, розвитку мисливського собаківництва громадяни можуть добровільно об'єднуватись у громадські організації мисливців. 3'ясовано, що система суб'єктів адміністративно-правового регулювання містить низку недоліків, основний з яких полягає в наявності колізій та нечіткому розмежуванні компетенції органів, оскільки досить часто повноваження різних суб'єктів збігаються. Крім того, деякі з легально визначених повноважень на практиці не реалізуються. Сформовано пропозиції щцодо вдосконалення діяльності системи суб'єктів адміністративно-правового регулювання в галузі мисливського господарства та полювання, а саме: узгодити компетенцію органів, які здійснюють управління в цій сфері, та виключити тотожні повноваження; конкретизувати повноваження органів місцевого самоврядування, громадських інспекторів з охорони довкілля та громадських мисливських інспекторів у Законі України «Про мисливське господарство та полювання», привести у відповідність до сучасного законодавства Положення, які регулюють діяльність останніх; деталізувати в Законі України «Про мисливське господарство та полювання» форми залучення громадськості до здійснення регулювання в зазначеній сфері; наділити контролюючими повноваженнями у сфері мисливського господарства одного із суб' 'єтів державного регулювання в ијй галузі та усунути дублюючі повноваження інших органів.

Ключові слова: мисливське господарство та полювання, адміністративно-правове регулювання, суб'єкти адміністративно-правового регулювання мисливського господарства та полювання.

T. M. Savchenko. The system of subjects of administrative and legal regulation in hunting economy and shooting

This article explores the state of legislative consolidation of the system of subjects of administrative and legal regulation in the field of hunting and hunting, peculiarities of the division of their powers, the main problems of the system and possible ways of solving them. Particular attention is paid to the issue of public participation in regulating this area. It is emphasized that involvement of the public in the management of public affairs is considered one of the basic principles of ensuring democratic development of society, which helps to establish a systematic dialogue between the authorities and the public, improve the quality of preparation and decision-making on important issues of state and social development, create conditions for publicity, openness transparency in the activities of the authorities. It is determined that the subject of state regulation in the sphere of hunting economy is recognized by the legislator and public organizations of hunters, noting that in order to satisfy their legitimate interests in hunting, promoting the conduct of hunting economy, the development of hunting dog breeding, citizens can voluntarily unite in the community. It is found that the system of subjects of

(C) Т. М. Савченко, 2019

ISSN 2521-6473

Правова позиція, № 3 (24), 2019 
administrative and legal regulation contains a number of shortcomings, the main of which is the existence of conflicts and a clear delineation of the competence of the authorities, since quite often the powers of different entities coincide. In addition, some of the legally defined powers are not implemented in practice. Suggestions have been made to improve the activities of the system of administrative and legal entities in the field of hunting and hunting, namely: to harmonize the competence of the bodies responsible for management in this sphere and to exclude the same powers; to specify the powers of local self-government bodies, public environmental inspectors and public hunting inspectors in the Law of Ukraine "On Hunting and Hunting"; to detail in the Law of Ukraine "On Hunting and Hunting" the forms of involvement of the public in the implementation of regulation in this area; to grant controlling powers in the field of hunting to one of the subjects of state regulation in this field and to eliminate the duplicate powers of other bodies. of hunting

Key words: hunting, administrative and legal regulation, subjects of administrative and legal regulation

Постановка проблеми. Оптимальне здійснення мисливського господарства та полювання залежить від ефективності діяльності органів державної влади, які забезпечують адміністративно-правове регулювання у вказаній сфері. Стан розвитку галузі є наслідком реалізації суб'єктами наданих їм законних повноважень.

Проведений аналіз змісту «Оцінки виконання Стратегії державної екологічної політики України на період до 2020 року та Національного плану дій з охорони навколишнього природного середовища на 2011-2015 роки», виявив існування низки проблем у галузі охорони навколишнього природного середовища, зумовлених недосконалим організаційно-правовим механізмом охорони довкілля, що своєю чергою актуалізує потребу вдосконалення його інституційної та функціональної складових частин [1, с. 99]. Це стосується також і регулювання у галузі мисливського господарства та полювання.

В умовах стрімкого розвитку галузі мисливського господарства та полювання як, по суті, одного з видів природокористування особливої уваги потребує існування проблеми раціонального використання, охорони та відтворення природних ресурсів. А тому органи державної влади та місцевого самоврядування, діяльність яких покликана забезпечувати охорону навколишнього середовища, відіграють найважливішу роль у вирішенні цієї проблеми та повинні сприяти реалізації принципу поєднання приватних інтересів природокористувачів з суспільними.

Аналіз останніх досліджень і публікацій. Дослідженням зазначеної теми займались такі науковці, як О.В. Артеменко, А.П. Гетьман, І.А. Городецька, І.Г. Гуль, І.І. Світлак, В.В. Овдієнко, О.О. Томин та інші.

Мета статті полягає в узагальненні системи суб'єктів адміністративно-правового регулювання в галузі мисливського господарства та полювання, визначенні стану правового регулювання їх діяльності, а також розмежуванні компетенції органів державної влади та місцевого самоврядування та на цій підставі сформулювати основні пропозиції щодо вдосконалення чинного законодавства.

Виклад основного матеріалу. Думки науковців стосовно визначення поняття «суб'єкт адміністративно-правового регулювання» різняться. Одні автори під цим терміном розуміють джерело впливу того, хто виконує функції керівництва і впливає на об'єкт з метою переведення його у новий стан [2, с. 9]. Деякі визначають суб'єкт як елемент (управляючу систему) системи управління, що генерує процес іiї функціонування [3, с. 220]. Інші розкривають зміст цього поняття як структурно-окреслених спільнот людей з органами управління, що формуються ними та керівним складом [4, с. 14]. В.Ю. Волков підсумовує, що між усіма цими визначеннями немає принципових відмінностей, та фігурує ідея керівного впливу суб'єкта, наділеного управлінськими функціями, на об'єкт.

В.Ю. Волков зазначає, що поширеною є позиція стосовно визначення державного управління в широкому та вузькому розумінні. На його думку, можна вважати, що державне управ- 
ління в широкому значенні можна розглядати як адміністративно-правове регулювання, яке здійснюється державними органами усіх гілок влади та недержавними інституціями, а у вузькому - лише органами виконавчої влади [5, с. 145].

Класифікація суб'єктів адміністративно-правового регулювання в науці теж визначається по-різному. Усталеним $є$ підхід, за якого виділяють органи загальної та спеціальної компетенції [6, с. 70]. Зокрема у галузі мисливського господарства до органів першої групи відносять Кабінет міністрів України, органи місцевого самоврядування, державні адміністрації. До другої ж групи можна віднести: Міністерство екології та природних ресурсів України, Міністерство аграрної політики та продовольства України, Державне агентство лісових ресурсів тощо, для яких адміністративно-правове регулювання в екологічній сфері є основним напрямом діяльності.

Інший підхід до класифікації суб’єктів регулювання, запропонований В.В. Костицьким, полягає у виділенні двох рівнів їх функціонування - загальнодержавного та територіального (місцевого) [7, с. 468]. Зокрема у сфері мисливського регулювання до загальнодержавних належать Кабінет Міністрів України, міністерства та агентство, тоді як до місцевих - органи місцевого самоврядування, державні адміністрації та територіальні органи Держлісагентства та міністерств.

О.В. Артеменко, аналізуючи систему суб'єктів адміністрування у сфері охорони навколишнього природного середовища, пропонує розширену класифікацію, зокрема: за територіальним масштабом діяльності - загальнодержавні та місцеві; за характером, напрямами роботи та повноваженнями - загальної компетенції та спеціальної, органи виняткової компетенції, громадськість [8, с. 116 ].

В.В. Овдієнко стверджує, що правовідносини у сфері мисливства належать до кола суспільних відносин, у яких участь органів публічної влади є обов'язковою. Управління мисливським господарством входить в систему державного управління в галузі охорони і використання тваринного світу й, по суті, є найважливішим засобом забезпечення раціонального ведення мисливства [9, с. 14].

Розділ II Закону України «Про мисливське господарство та полювання» присвячений державному регулюванню у галузі мисливського господарства та полювання [10]. Відповідно до статті 4 державне регулювання у галузі мисливського господарства та полювання здійснюють Кабінет Міністрів України, Рада міністрів Автономної Республіки Крим, місцеві державні адміністрації, центральний орган виконавчої влади, що забезпечує формування державної політики у сфері охорони навколишнього природного середовища (Міністерство екології та природніх ресурсів України), центральний орган виконавчої влади, що забезпечує формування державної політики у сфері лісового та мисливського господарства (Міністерство аграрної політики та продовольства України), центральний орган виконавчої влади, що реалізує державну політику у сфері лісового та мисливського господарства (Державне агентство лісових ресурсів України), та інші центральні органи виконавчої влади відповідно до їх повноважень.

Органам місцевого самоврядування за цим Законом та іншими законами України можуть бути надані окремі повноваження органів виконавчої влади у сфері державного регулювання мисливського господарства та полювання.

Суб'єктом державного регулювання у сфері мисливського господарства законодавець визнає і громадські організації мисливців, зазначаючи, що з метою задоволення своїх законних інтересів у здійсненні полювання, сприяння веденню мисливського господарства, розвитку мисливського собаківництва громадяни можуть добровільно об'єднуватись у громадські організації мисливців. Таким чином, можна зробити висновок про підтримку законодавцем широкого розуміння поняття «суб'єкт адміністративно-правового регулювання».

ISSN 2521-6473

Правова позиція, № 3 (24), 2019 
А тому, беручи за основу широке розуміння адміністративно-правового регулювання, слід звернути особливу увагу на такий суб’єкт, як громадськість.

Забезпечення участі громадян у здійсненні регулювання у галузі мисливства та полювання $€$ реалізацією конституційно гарантованого права кожного українця на участь в управлінні державними справами, закріпленого в статті 38 Конституції України.

Варто погодитися з думкою, що залучення громадськості до управління державними справами вважається одним із основоположних принципів забезпечення демократичного розвитку суспільства, який сприяє налагодженню системного діалогу між органами влади і громадськістю, підвищенню якості підготовки, та прийняття рішень 3 важливих питань державного і суспільного розвитку, створення умов гласності, відкритості і прозорості в діяльності органів влади [14].

Аналіз положень законодавства дає змогу визначити, що громадськість в сучасних умовах бере участь у здійсненні адміністративно-правового регулювання у сфері мисливства, виконуючи частину функцій, покладених на органи державної влади, а також реалізуючи власні права, надані їм законодавством.

Так, у Постанові Кабінету Міністрів України «Про забезпечення участі громадськості у формуванні та реалізації державної політики» [15] визначено основні вимоги до організації і проведення органами виконавчої влади консультацій з громадськістю з питань формування та реалізації державної політики. Консультації з громадськістю проводяться у формі публічного громадського обговорення, електронних консультацій з громадськістю (безпосередні форми) та вивчення громадської думки (опосередкована форма).

При цьому національне законодавство визначає такі засоби участі громадськості у прийнятті управлінських рішень, як громадська рада, громадська експертиза, загальні збори громадян, місцеві ініціативи та самоорганізація населення. Рішення, прийняті у процесі консультування з громадськістю за допомогою вище названих засобів, мають рекомендаційний характер, на відміну від рішень, що передбачають прямий вплив громадськості на процес їх прийняття за допомогою таких засобів, як референдум.

Законодавством визначено, що процедури участі громадськості у формуванні та реалізації державної політики (консультації з громадськістю у формі публічного громадського обговорення) обов'язково проводяться щодо проектів: нормативно-правових актів, що мають важливе суспільне значення і стосуються прав і обов'язків громадян, а також актів, якими передбачається надання пільг чи встановлення обмежень для суб'єктів господарювання та інститутів громадянського суспільства, здійснення повноважень місцевого самоврядування; регуляторних актів; державних і регіональних програм економічного, соціального і культурного розвитку, рішень стосовно стану їх виконання, а також щодо звітів головних розпорядників бюджетних коштів про їх витрачання за минулий рік. Причому варто відмітити, що орган виконавчої влади має забезпечити врахування результатів проведення консультацій під час прийняття ним остаточного рішення або в подальшій роботі [14].

Так, Державним агентством лісових ресурсів щорічно затверджується орієнтовний план щодо проведення консультацій з громадськістю. Наприклад, в такому плані на 2019 рік у галузі мисливського господарства передбачається обговорення проекту наказу Мінагрополітики «Про затвердження правил державного обліку мисливських тварин» відповідно до статті 6 Закону України «Про мисливське господарство та полювання».

Крім того, громадськість бере участь і в здійсненні контрольної функції адміністративно-правового регулювання. Так, відповідно до статті 58 Закону України «Про тваринний світ» [16] громадський контроль у галузі охорони, використання і відтворення тваринного світу здійснюється громадськими інспекторами з охорони довкілля та громадськими інспекторами 
Державного агентства лісових ресурсів України і центрального органу виконавчої влади, що реалізує державну політику у сфері рибного господарства, органів виконавчої влади Автономної Республіки Крим з питань мисливського господарства та полювання. Повноваження громадських інспекторів у галузі охорони, використання і відтворення тваринного світу визначаються положеннями про них, затвердженими Міністерством екології та природних ресурсів України, Міністерством аграрної політики та продовольства України.

Відповідно до ст. 38 Закону громадський контроль за полюванням здійснюється громадськими інспекторами з охорони довкілля та громадськими мисливськими інспекторами. Правовий статус цих громадських представників визначає низка нормативно-правових актів, зокрема, Положення про громадських інспекторів з охорони довкілля від 27 лютого 2002 року [17], Положення про громадських мисливських інспекторів від 1 березня 2002 року [18] тощо. Однак проблемою є застарілість норм названих підзаконних актів, які не відповідають сучасному стану речей та не узгоджуються з іншими законодавчими актами. Внаслідок цього простежується низька ефективність участі громадськості в здійсненні контрольної функції в галузі мисливського господарства та полювання, що пов'язано з наявністю низки колізій у чинному законодавстві, яке визначає правовий статус громадських інспекторів. Як зазначає I.I. Світлак, найбільшим недоліком практичної реалізації закріпленого в законодавстві інституту громадських інспекторів $є$ розрив між правовою нормою та її виконанням. Громадські інспектори не завжди мають можливість реалізувати права, гарантовані їм законодавством [19, с. 51].

Крім того, як зазначають науковці, залишаються невирішеними питання повноти врахування інтересів і думки громадськості, механізмів захисту і оскарження прийнятих рішень. Потребують подальшого удосконалення на законодавчому рівні процедури участі громадськості у формуванні та реалізації державної політики в частині відсутності законодавчих можливостей внесення окремими громадянами (на відміну від громадських рад та інститутів громадянського суспільства) пропозицій до плану проведення консультацій 3 громадськістю; відсутності детального порядку забезпечення репрезентативності соціальних груп населення, суб'єктів господарювання, інститутів громадянського суспільства, органів місцевого самоврядування та інших заінтересованих суб'єктів органами виконавчої влади у процесі організації консультацій з громадськістю у формі публічного громадського обговорення; відсутності правових засад відповідальності органів виконавчої влади за порушення встановлених процедур проведення консультацій з громадськістю [20].

Наголошується також на наявності наступних недоліків щодо участі громадськості в регулюванні зазначеної сфери:

- незважаючи на високий рівень законодавчого регулювання застосування окремих засобів і форм залучення громадськості до управління, відсутнім є системний підхід до формування послідовної, єдиної і комплексної державної політики з цього питання;

- розмаїття широкого спектру запропонованих засобів, форм взаємодії та участі громадськості в управлінні державними справами нівелюється відсутністю реальних і дієвих механізмів врахування іiі законних інтересів;

- неузгодженість нормативно-правової бази проявляється, зокрема, в унормуванні різних суб'єктів участі в управлінні - громадяни, недержавні природоохоронні організації, інститути громадянського суспільства, хоча усі вони об'єднуються поняттям громадськості $[14$, c. 24$]$.

Стратегією державної екологічної політики України на період до 2020 року передбачено участь громадськості та суб'єктів господарювання у формуванні та реалізації екологічної політики, а також урахування їхніх пропозицій у ході вдосконалення природоохоронного законодавства [21].

ISSN 2521-6473

Правова позиція, № 3 (24), 2019 
Система суб'єктів адміністративно-правового регулювання містить низку недоліків, основний з яких полягає в існуванні колізій та нечіткому розмежуванні компетенції органів, оскільки досить часто повноваження різних суб'єктів збігаються. Крім того, деякі з легально визначених повноважень на практиці не реалізуються.

В.В. Овдієнко зазначає, що у Законі України «Про мисливське господарство та полювання» не визначено компетенцію центрального органу виконавчої влади, що забезпечує формування державної політики у сфері лісового та мисливського господарства, зокрема, щодо контролю за веденням державного кадастру мисливських тварин, а підзаконні нормативні акти суперечать вказаному Закону як у визначенні суб'єктів державного кадастру мисливських тварин, так і в обсязі наданих їм повноважень у цій сфері. Вбачається необхідним внести зміни до Положення про державну систему моніторингу довкілля, де перелік суб'єктів моніторингу тваринного світу викласти у відповідності до діючої системи органів виконавчої влади [9].

Однією з найбільш важливих, але одночасно і проблематичних, функцій адміністративно-правового регулювання є функція контролю. О.О. Томин розуміє під контролем у галузі мисливства і полювання систематичну, конструктивну діяльність державних органів та посадових осіб, органів місцевого самоврядування та громадських організацій, яка спрямована на забезпечення відповідності мисливської діяльності та полювання вимогам чинного законодавства України.

Науковець зазначає, що до альтернативних шляхів реформування функції контролю у досліджуваній сфері належать: створення служби охорони державного мисливського фонду для підвищення ефективності боротьби з браконьєрством та забезпечення ії необхідними матеріально-технічними засобами (приміщеннями, автотранспортом, засобами зв'язку та комп'ютерною технікою); розширення повноважень працівників лісової охорони, єгерської служби, єгерів мисливських господарств, громадських організацій мисливців, громадських мисливських інспекторів щодо здійснення контролю за охороною, використанням державного мисливського фонду; збільшення державного фінансування для проведення комплексу екологоконтрольних заходів; поширення положення статті 40 Закону України «Про мисливське господарство та полювання» і на громадських мисливських інспекторів, надавши їм аналогічний правовий та соціальний захист, яким наділені і працівники, що здійснюють державний контроль у галузі мисливського господарства та полювання.

Для забезпечення належного і дієвого державного контролю у галузі мисливського господарства і полювання доцільно: 1) розробити і затвердити Інструкцію про стимулювання та матеріально-технічне забезпечення осіб, уповноважених здійснювати контроль у галузі мисливського господарства та полювання; 2) ст. 40 Закону «Про мисливське господарство та полювання» викласти у наступній редакції: «Правовий та соціальний захист працівників, уповноважених здійснювати державний та громадський контроль у галузі мисливського господарства та полювання» і поширити їі дію на громадських інспекторів [22].

Висновки 3 дослідження і перспективи подальших розвідок у цьому напрямі. Підсумовуючи все вищевикладене, можна сформувати певні пропозиції щодо вдосконалення діяльності системи суб'єктів адміністративно-правового регулювання в галузі мисливського господарства та полювання. Зокрема, необхідно:

1. Узгодити компетенцію органів, які здійснюють управління в цій сфері, та виключити тотожні повноваження;

2. Конкретизувати повноваження органів місцевого самоврядування, громадських інспекторів з охорони довкілля та громадських мисливських інспекторів у Законі України «Про мисливське господарство та полювання». Привести у відповідність до сучасного законодавства Положення, які регулюють діяльність останніх; 
3. Деталізувати в Законі України «Про мисливське господарство та полювання» форми залучення громадськості до здійснення регулювання в зазначеній сфері;

4. Наділити контролюючими повноваженнями у сфері мисливського господарства одного із суб'єктів державного регулювання в цій галузі та усунути дублюючі повноваження інших органів.

\section{Список використаних джерел:}

1. Городецька І.А. Система суб’єктів адміністративно-правового регулювання в галузі охорони, використання, відтворення тваринного світу. Науковий вісник Ужгородського університету. 2017. с. 90-101. URL: http://www.visnyk-juris.uzhnu.uz.ua/file/No.47/part_2/24.pdf.

2. Колпаков В.К. Адміністративне право України: підручник. Київ : Юрінком Інтер, $2001.752 \mathrm{c}$.

3. Булыгин Ю.Е. Организация социального управления (основные понятия и категории) : словарь-справочник. Москва : Контур. 1999. 254 с.

4. Бандурка О.М. Управління в органах внутрішніх справ України : підручник. Харків : Ун-т внутр. справ. 1998. 254 с.

5. Волков В.Ю. Суб'єкти адміністративно-правового регулювання в галузі стандартизації та сертифікації. Форум права. 2013. № 1. С. 145-149.

6. Гетьман А.П. Правова охорона довкілля: сучасний стан та перспективи розвитку : монографія. Харків : Право, 2014. 784 с.

7. Костицький В.В. Екологія перехідного періоду: право, держава, економіка (економіко-правовий механізм навколишнього природного середовища в Україні) : монографія. Київ : УСП МСБ “Eusmeu”. 2003. 772 с.

8. Артеменко О.В. Система суб' єктів адміністрування у сфері охорони навколишнього природного середовища. Університетські наукові записки. 2014. № 3 (51). С. 114-119.

9. Овдієнко В.В. Правове регулювання мисливства в Україні. Автореферат дисертації на здобуття наукового ступеня кандидата юридичних наук. 12.00.06. Харків. 2004. URL: http://dspace.nlu.edu.ua/bitstream/123456789/5900/1/Ovdienko_2014.pdf.

10. Про мисливське господарство та полювання. Закон України № 1478-III 22.02.2000. Верховна рада України. URL: https://zakon.rada.gov.ua/laws/show/1478-14.

11. Про затвердження Положення про Міністерство аграрної політики та продовольства України. Поставнова Кабінету міністрів України від 25 листопада 2015 р. № 1119. Офіиійний вісник України. URL: https://zakon.rada.gov.ua/laws/show/1119-2015-\%D0\%BF.

12. Про Міністерство аграрної політики та продовольства України. Указ Президента від 23.04.2011 № 500/2011. Офіціийний вісник України. URL: https://zakon.rada.gov.ua/laws/ show/500/2011.

13. Положення про обласні управління лісового та мисливського господарства Державного агентства лісових ресурсів України. Наказ Міністерства аграрної політики та продовольства України від 21.03.2012 № 134. URL: https://zakon.rada.gov.ua/laws/show/z0729-12.

14. Кравець П., Павліщук О., Станкевич О. Законодавчо-правові засади доступу до інформації та участі громадськості в управлінні лісовим господарством. Київ. 2015. 33c.

15. Про забезпечення участі громадськості у формуванні та реалізації державної політики. Постанова Кабінету Міністрів України від 03 листопада 2010 року № 996. Офіційний вісник Украӥни. URL: https://zakon.rada.gov.ua/laws/show/996-2010-\%D0\%BF.

16. Про тваринний світ. Закон України від 03.03.1993 № 2894-III. Відомості Верховної Ради України: URL: https://zakon.rada.gov.ua/laws/show/2894-14. 
17. Про затвердження Положення про громадських інспекторів $з$ охорони довкілля. Наказ Міністерства екології та природних ресурсів України від 27 лютого 2002 року № 88. Офіџійний вісник України. URL: https://zakon.rada.gov.ua/laws/show/z0276-02.

18. Про затвердження Положення про громадських мисливських інспекторів. Наказ Державного комітету лісового господарства України від 1 березня 2002 року № 27. Офіиійний вісник України. URL: https://zakon.rada.gov.ua/laws/show/z0290-02.

19. Світлак I.I. Правовий статус громадських інспекторів у сфері боротьби з порушеннями правил полювання та рибальства: законодавчі колізії. Правничий вісник Універcumemy «КРОК». Ст. 48-52. URL: file:///C:/Users/\%D0\%9F\%D0\%9A/Downloads/Pvuk $2011 \_8 \_10 \% 20(1)$.pdf.

20 . Участь громадськості у процесі прийняття рішень на місцевому рівні : посіб. Київ : Ленвіт, 2012. 64 c. URL: www.britishcouncil.org.ua.

21. Про Основні засади (стратегію) державної екологічної політики України на період до 2020 року. Закон України від 21 грудня 2010 року. URL: https://zakon.rada.gov.ua/laws/ show/2818-17.

22. Томин О.О. Правове регулювання мисливства та полювання в Україні (на матеріалах Карпатського регіону). Автореферат дисертації на здобуття наукового ступеня кандидата юридичних наук. 12.00.06. Київ. 2009. 
УДК 342.9

DOI https://doi.org/10.32836/2521-6473-2019-3-79-83

\author{
В. В. Сагайдак, здобувач кафедри \\ адміністративного та митного права \\ Університету митної справи та фрінансів
}

\title{
МАЙНО ЯК ОБ'ЄКТ ОПОДАТКУВАННЯ
}

Стаття присвячена дослідженню сучасних підходів до розуміння майна як об'єкта оподаткування, а також особливостям ичивільно-правового та податково-правового підходів до визначення категорії «майно». Автором визначено нормативне закріплення майна у цивільному украӥнському законодавстві та законодавстві зарубіжних країн. Проаналізовано думки науковиів щодо проблеми розмежування поняття «майно» в цивільному та податковому значенні. Наголошено, шзо у разі, якщо терміни, які застосовуються у Податковому Кодексі, не визначаються ним, то слід використовувати їх у значенні, встановленому іншими законами. Підкреслено, що майно у податковому праві слід розглядати виключно тодi, коли з ним пов'язується податковий обов'язок у платника податків.

Наголошено на різних аспектах, яким приділяється увага під час характеристики майна з точки зору цивільного та податкового права. Якщо з позичї цивілістики майно розуміється як об'єкт, щуодо якого можливо здійснювати право власності, то в руслі податково-правового регулювання майно має виняткову прив'язку до випливаючого з факту його наявності податкового обов 'язку власника. При иььму першочергове значення має саме реалізація иього обов 'язку перед державою. Автор в ході співвіднесення податково-правових та цивільно-правових підходів до характеристики майна приділив особливу увагу виокремленню спільних та відмінних рис. Окрім иьього, автор співставив обсяг, який вміщуе у собі поняття «майно» залежно від характеру пов'язаних із ним правовідносин та нормативного регулювання.

Додатково в межах наукової роботи автор зупинив увагу на питанні податкового обов 'язку, розкривши його сутність та підстави виникнення у платника податків. На підставі проведеної систематизації існуючих у теорії та на практиці підходів до питання використання поняття «майно» у податкових та ицвільних відносинах автор сформував власні висновки. Так, з позииї автора використання иивільно-правової дефініції «майно» у податкових правовідносинах є можливим. Але при иььому сама категорія «майно» у податковому праві є значно вужчою. Ї̈ можливо виявити винятково тоді, коли із нею пов'язаний певний податковий обов'язок у платника податків.

Ключові слова: об'єкт оподаткування, майно, податковий обов'язок, Цивільний кодекс, Податковий кодекс.

\section{V. Sahaidak. Property as an object of taxation}

The article is devoted to the study of modern approaches to understanding property as an object of taxation, as well as to the peculiarities of civil and tax legal approaches to the definition of the category "property". The author analyzes the normative definitions of property in the Ukrainian civil legislation and the legislation of foreign countries. The opinions of scientists on the problem of differentiation of the concept of "property" in the civil and tax sense are analyzed. It is noted that if the terms that are used in the Tax Code are not defined by it, then they should be used in the meaning established by other laws. It is emphasized that property in tax law should be considered only when the tax liability of the taxpayer is associated with it.

It is marked different aspects paid attention that at description of property from the point of view of civil and tax law. If from position of civility property understands as an object in relation to that it maybe to carry out the right of ownership, then in the river-bed of the tax-legal adjusting property has exceptional attachment to swimming out from the fact of his presence of tax duty of proprietor. Thus realization of this duty has a nearterm value exactly before the state. An author during correlation of the tax-legal and civil legal going near description of property spared the special attention to the selection of general and excellent lines. Except it, an

(C) В. В. Сагайдак, 2019

ISSN 2521-6473

Правова позиція, № 3 (24), 2019 
author confronted a volume that contains in itself a concept "property" depending on character of the legal relationships related to him and normative adjusting.

Additionally within the limits of the advanced study an author stopped attention for the question of tax duty, exposing his essence and grounds of origin for a taxpayer. On the basis of the conducted systematization of existing at a theory and in practice going near the question of the use of concept "property" in tax and civil relations an author formed own conclusions. So from position of author of the use of civil legal definition "property" in tax legal relationships is possible. But here category "property" in a tax right is considerably more narrower. Her it maybe to educe exceptionally then, when with her the constrained is certain tax duty for a taxpayer.

Key words: object of taxation, property, tax liability, civil code, tax code.

Постановка проблеми. Об'єктом оподаткування в будь-якій країні може виступати доход, прибуток, здійснення певних операцій або майно. При цьому оподаткування перших трьох об’єктів характеризується активною поведінкою платника, їх поява зумовлена єдиною метою - отриманням платником коштів. У разі припинення відповідної діяльності об'єкт не утворюється, отже, і податковий обов'язок не виникає. Інша ситуація складається із майном, наявність якого у платника далеко не завжди є передумовою отримання грошових коштів, а відповідний майновий податок сплачувати потрібно незалежно від цього. Саме тому майно $\epsilon$ специфічним об'єктом оподаткування, який докорінним чином відрізняється від усіх інших його різновидів, що зумовлює потребу детального й всебічного вивчення особливостей оподаткування майна.

Аналіз останніх досліджень і публікацій. Питанням оподаткування майна займалися багато вітчизняних вчених. Зокрема, слід відмітити роботи таких дослідників, як В.В. Токар, С.А. Митяй, С.Г. Пепеляєв, Г.Ф. Шершеневич І.В. Мазур, Н.В. Габельчук, А.С. Дубоносова, I.В. Педь, А.В. Чуркін, О.О. Коваль, А.М. Соколовська та інші. Водночас, незважаючи на значну кількість досліджень, питання оподаткування нерухомості все ж недостатньо висвітлено. Сталою залишається проблема співвідношення цивільно-правового та податково-правового розуміння категорії «майно».

Метою статті $\epsilon$ - визначити актуальні підходи до розуміння майна як об'єкта оподаткування, а також охарактеризувати особливості цивільно-правового та податково-правового підходів до визначення категорії «майно».

Виклад основного матеріалу. Аналіз стану оподаткування нерухомості в Україні наразі $\epsilon$ доцільним. Зумовлено це необхідністю урахування проведеної податкової реформи, визначення основних проблем нормативного закріплення відповідних правових механізмів майнових податків, актуальністю питання щодо впровадження досвіду інших країн світу з питань майнового оподаткування, а також окреслення напрямів вдосконалення податкового законодавства у цілому.

Вступаючи у податкові правовідносини, платники насамперед мають реалізувати свій податковий обов'язок. Цей обов'язок закріплено на конституційному рівні, адже відповідно до ст. 67 Конституції України кожен зобов'язаний сплачувати податки і збори в порядку і розмірах, встановлених законом [1]. При цьому суть податкового обов'язку деталізується у нормах Податкового кодексу України. Так, відповідно до положень ст. 36 даного нормативного акту податковим обов'язком визнається обов'язок платника податку обчислити, задекларувати та сплатити суму податку та збору в установленому порядку і визначені податковим законодавством строки. При цьому ст. 67 встановлено, що податковий обов'язок виникає у платника податку з моменту настання обставин, з якими цей Кодекс та закони з питань митної справи пов'язує сплату ним податку [2].

Основною підставою для виникнення податкового обов'язку можна вважати появу об'єкта оподаткування. Такий висновок витікає із положень ст. 22 Податкового кодексу Укра- 
їни, яка встановлює орієнтовний, але не винятковий, перелік об'єктів оподаткування (майно; товари; дохід; прибуток або його частина; обороти з реалізації товарів, робіт, послуг; операції 3 постачання товарів, робіт, послуг) та встановлює, що до їх кола можуть належати й інші об'єкти, визначені податковим законодавством, з наявністю яких податкове законодавство пов'язує виникнення у платника податкового обов'язку [2]. Отже, підставою виникнення податкового обов'язку можна вважати складний юридичний факт, який полягає у: 1) наявності (появі) певного об'єкта матеріального світу; 2) віднесенні цього об'єкта податковим законодавством до кола об'єктів оподаткування. При цьому майно в орієнтовному переліку об'єктів оподаткування займає перше місце.

До характеристики майна, яке є підставою для оподаткування, можна підходити по-різному. При цьому потрібно враховувати підходи, що застосовуються до майна не тільки у податковому, а й в інших підгалузях та галузях права. Наприклад, Г.Ф. Шершеневич виокремлював майно в юридичному та економічному значенні. На його переконання, в економічному сенсі майно є благом (речі та права на чужі дії), що перебуває у володінні особи. У юридичному розумінні під майном він розумів сукупність майнових, тобто тих, що підлягають грошовій оцінці, юридичних відносин, в яких перебуває особа. При цьому зміст майна з юридичної точки зору зводився, з одного боку, до сукупності речей, що належать особі на праві власності, прав на чужі дії, а з іншого - до сукупність зобов'язань, що покладені на особу. У першому випадку йдеться про актив майна, у другому - про його пасив [3, с. 95].

Досліджуючи види об’єктів оподаткування, А.С. Дубоносова робить акцент на неможливості тотожного підходу до майна в цивільному і податково-правовому (публічному) значенні. Вона пише: «майно як об’єкт оподаткування охоплює тільки ті цивільно-правові форми (об'єкти цивільних прав), за наявності яких у платника податків виникає податковий обов'язок. За таких обставин майно як об'єкт оподаткування слід розглядати винятково тоді, коли 3 ним пов'язується податковий обов'язок у платника податків, тобто в контексті закону про конкретний майновий податок, що представлений та діє в системі оподаткування України». [4, с. 144-145]. У цілому з таким підходом можна погодитись - саме таким чином платник підходить до відносин оподаткування майна на практиці, але доцільним вбачається деталізувати, про які саме форми йдеться, а для цього варто визначитись із нормативним закріпленням майна, у тому числі в нормативних актах, що закріплюють цивільно-правові норми.

У цивільному українському законодавстві майном як особливим об'єктом вважаються окрема річ, сукупність речей, а також майнові права та обов'язки (ст. 190 Цивільного кодексу України) [5]. Також цивільне законодавство конкретизує різні види майна, застосовуючи такі категорії, як нерухомі та рухомі речі, речі подільні та неподільні, споживні та неспоживні тощо [5, ст. 177-198]. При цьому до кола речей цивілісти відносять будь-які матеріальні предмети зовнішнього світу, що мають зовнішній по відношенню до людини характер та мають таку властивість, як здатність задовольняти потреби людини [6, с. 205-206].

Схожий підхід можна знайти у цивільному законодавстві інших країн, де до об'єктів цивільних прав належать речі, включаючи гроші й цінні папери, інше майно, зокрема, майнові права (ст. 128 Цивільного кодексу Російської Федерації). При цьому відповідно до положень ч. 2. ст. 38 Податкового кодексу Російської Федерації під майном розуміють види об'єктів цивільних прав (за винятком майнових прав), що належать до майна відповідно до Цивільного кодексу Російської Федерації [7, с. 193]. Отже, в цій країні законодавець розмежовує цивільно-правовий та податково-правовий підхід до визначення категорії «майно».

В Україні застосовується інший підхід. Відповідно до положень п. п. 14.1.105 п. 14.1 ст. 14 Податкового кодексу України термін «майно» під час оподаткування застосовується у значенні, наведеному в Цивільному кодексі України [2].

ISSN 2521-6473

Правова позиція, № 3 (24), 2019 
У науковій літературі немає єдності думок щодо того, потрібно розмежовувати поняття «майно» в цивільно-правому значенні та у податково-правовому чи ні. А.В. Чуркін та С.Г. Пепеляєв наголошують, що в цьому немає потреби, та пропонують для цілей оподаткування використовувати дефініцію «майно» 3 цивільного законодавства [8, с. 224; 9]. 3 таким твердженням не погоджується А.С. Дубоносова, яка вказує: «Термінологія податкового законодавства має свої особливості, що зумовлені специфікою відносин. Якщо в умовах цивільно-правових відносин характеристика майна передусім пов'язується з відносинами власності або користування, то податково-правове регулювання орієнтоване на зумовленість виникнення та реалізації податкового обов'язку платника податків тим або іншим майном. Проте це не $є$ підставою для того, щоб використовувати сталі поняття та терміни в іншому значенні чи наповнювати їх іншим змістом, коли для цього немає об'єктивних підстав юридичного характеру. Відповідно до Цивільного кодексу України до майнових відносин, заснованих на адміністративному або іншому владному підпорядкуванні однієї сторони іншій, а також до податкових, бюджетних відносин цивільне законодавство не застосовується» [5, ч. 2 ст. 1]. 3 такою позицією не можна погодитись $з$ наступних причин.

По-перше, терміни, що застосовуються під час оподаткування, визначені у ст. 14 Податкового кодексу України. При цьому, як ми вже відмічали, визначення поняття «майно» містить відсильну норму до цивільного законодавства. По-друге, навряд чи можна стверджувати про неможливість використання положень, закріплених цивільним законодавством, у регулюванні податкових відносин. Дійсно, ст. 1 Цивільного кодексу України встановлено, що до майнових відносин, заснованих на адміністративному або іншому владному підпорядкуванні однієї сторони іншій, а також до податкових, бюджетних відносин, цивільне законодавство не застосовується, якщо інше не встановлено законом [5]. При цьому саме такий випадок, закріплений законом, ми маємо у ст. 5 Податкового кодексу України, відповідно до якої терміни, що застосовуються у цьому Кодексі і не визначаються ним, використовуються у значенні, встановленому іншими законами [2]. 3 цього можна зробити висновок, що навіть у разі відсутності відсилки для Цивільного кодексу України у ст. 14 Податкового кодексу України під час визначення поняття «майно», ми все одно мали б звертатися до цивільного законодавства.

Інша справа - співвідношення обсягу кола цивільних та податкових відносин, що стосуються майна. Аналізуючи подібний аспект, О.О. Коваль справедливо зауважує, що «розуміння майна в цілях оподаткування є значно вужчим, ніж цивільно-правове. Визначення майна, надане у ст. 190 ЦК України (майном як особливим об’єктом вважаються окрема річ, сукупність речей, а також майнові права та обов'язки), не може у такій редакції застосовуватися для цілей оподаткування під час визначення майна як об'єкта оподаткування. Для цілей оподаткування головним $\epsilon$ правове становище такого майна в межах виконання податкового обов'язку, адже не кожне майно може бути об'єктом оподаткування відповідно до положень ПК України - сьогодні до такого майна належать лише об'єкти житлової нерухомості та земельні ділянки» [10].

Як приклад вчений наводить особливості розповсюдження режиму нерухомого майна на об'єкти, які можуть рухатись. Так, відповідно до положень п. 1, ст. 181 ЦК України, режим нерухомої речі може бути поширений на повітряні та морські судна, судна внутрішнього плавання, космічні об'єкти, а також інші речі, права на які підлягають державній реєстрації [5]. При цьому О.О. Коваль зазначає, що відповідно до положень Податкового кодексу України оподаткуванню підлягає: 1) нерухомість, за володіння якої передбачено справляння податку на нерухоме майно, відмінне від земельної ділянки; 2) земельна ділянка, за володіння чи користування якою у юридичної чи фізичної особи виникає обов'язок зі сплати плати за землю [10]. Отже, існує цілком визначена різниця між цивільно-правовим та податково-правовим аспектом у розумінні категорії «майно». 
Висновки $з$ дослідження і перспективи подальших розвідок у цьому напрямі. За результатами дослідження систематизовано основні підходи до розуміння майна у податковому праві. Наголошено на особливостях диференціації цивільно-правового та податково-правового підходів до визначення категорії «майно». Доведено можливість використання податковим законодавством цивільно-правової дефініції майна. Обгрунтовано, що майно як об'єкт оподаткування є значно вужчою категорією, яку слід розглядати винятково тоді, коли з ним пов'язується податковий обов'язок у платника податків.

\section{Список використаних джерел:}

1. Конституція України від 28.06.1996 р. № 254к/96-ВР. Відомості Верховної Ради України. 1996. № 30. Ст. 141.

2. Податковий кодекс України від 02.12.2010 р. № 2755-VI. Відомості Верховної Ради Украӥни. 2011. № 13-17. Ст. 112.

3. Шершеневич Г.Ф. Учебник русского гражданского права (по изданию 1907 г.). Москва : СПАРК, 1995. 556 с.

4. Дубоносова А.С. Правове регулювання об’єкта оподаткування : дис. ... канд. юрид. наук: 12.00.07. Харків, 2009. 217 с.

5. Цивільний кодекс України від 16.01.2003 р. № 435-IV. Відомості Верховної Ради України. 2003. № 40-44. Ст. 356.

6. Гражданское право. Ч. 1 : [Учебник, 3-е изд. ] / Под ред. проф. А.П. Сергеева, проф. Ю.К. Толстого. Москва : Проспект, 1998. 624 с.

7. Комментарий к Налоговому кодексу Российской Федерации, частей первой и второй / Под общ. ред. Ю.Ф. Кваши. Москва : Юрайт-Издат, 2006. 1292 с.

8. Налоговое право : учеб. пособ. / Под ред. С.Г. Пепеляева. Москва : ИД ФБК-ПРЕСС, 2000. 608 c.

9. Чуркин А.В. Понятие «имущество» в гражданском и налоговом праве. Налоговед. № 1. 2004. C. 12-17.

10. Коваль О.О. Правове регулювання оподаткування нерухомого майна в Україні : дис. ... канд. юрид. наук : 12.00.07. Запоріжжя, 2014. С. 16. 
УДК 342.9

DOI https://doi.org/10.32836/2521-6473-2019-3-84-89

\author{
M. I. Coф'їн, кандидат юридичних наук, \\ докторант Науково-дослідного інституту \\ публічного права
}

\title{
ДО ПРОБЛЕМИ ПОДОЛАННЯ КОРУПЦЇ̈ В УКРАЇНІ В КОНТЕКСТІ РОЗРОБКИ КОНЦЕПТУАЛЬНИХ ЗАСАД УДОСКОНАЛЕННЯ ФІСКАЛЬНОЇ ПОЛІТИКИ
}

У статті на основі аналізу норм чинного законодавства Украӥни та наукових поглядів вчених визначено можливі шляхи подолання корупиї в Украӥні в контексті розробки концептуальних засад удосконалення фіскальної політики. Наголошено, що корупчія - ие складне і багатоаспектне (економічне, політичне, правове, морально-психологічне) соціальне явище, змістом якого є зумовлена політичними, економічними, соціальними і психологічними факторами система негативних поглядів, переконань, установок і діянь посадових осіб інститутів влади, держсавних і недержавних організацій, політичних партій, громадських організацій, спрямованих на задоволення особистих, корисливих, групових або корпоративних інтересів шляхом підкупу, хабарнищтва, зловживання владою, надання пільг і переваг всупереч суспільним інтересам. 3'ясовано, шо протидія корупиії-ие комплексний механізм, шо будується на певних принципах та відповідно до вимог чинного законодавства, має свій суб'єктно-об' єктний склад та відповідні інструменти, тобто форми, методи, способи та засоби протидї корупиії. Визначено, що протидія корупції в рамках удосконалення фіскальної політики України в умовах Євроінтеграції має здійснюватись у двох напрямах: перший - протидія корупиї в органах Державної податкової служби (під час формування державного бюджету за рахунок сплати податків); другий - протидія корупиіі під час витрати державних коштів. Встановлено, що важливими завданнями держави та ії органів $\epsilon$ : по-перше, створення прозорої системи ведення тендерів та державних закупівель; по-друге, здійснення суворого контролю за тим, як використовуються иі кошти, за якими напрямами тощо. Зроблено висновок, шо протидія корупиї повинна включати: 1) правові заходи, тобто створення відповідного правового поля для попередження вчинення корупиійних діянь посадовими особами; 2) організачійно-управлінські заходи; 3) покращення кадрового, матеріально-технічного та фінансового забезпечення уповноважених органів державної влади; 4) активне залучення громадськості до антикорупщійних заходів.

Ключові слова: корупція, протидія корупиіï, концептуальні засади, фіскальна політика, кадрове забезпечення, державні доходи, державні видатки.

M. I. Sofin. To the problem of overcoming corruption in Ukraine in the context of developing the conceptual framework for fiscal policy improvement

The article, based on the analysis of the norms of the current legislation of Ukraine and the scientific views of scientists, identifies possible ways to overcome corruption in Ukraine in the context of developing the conceptual framework for improving fiscal policy. It is emphasized that corruption is a complex and multidimensional (economic, political, legal, moral and psychological) social phenomenon whose content is caused by political, economic, social and psychological factors of the system of negative views, beliefs, attitudes and actions of officials of the institutions of power, state and non-governmental organizations, political parties, NGOs aimed at satisfying personal, self-serving, group or corporate interests through bribery, bribery, abuse of power, giving $h$ and benefits contrary to the public interest. It is found out that counteraction to corruption is a complex mechanism, built on certain principles and in accordance with the requirements of the current legislation, has its subject-object composition and appropriate instruments, which serve as appropriate forms, methods, methods and means. counteracting corruption. It is determined that the fight against corruption within the framework of improving the fiscal policy of Ukraine under the conditions of Eurointegration should be carried out in two directions: the first - the counteraction of corruption in the bodies of the State Tax Service

(C) M. I. Соф'ї̈, 2019 
(during the formation of the state budget at the expense of paying taxes); the second is to counteract corruption when spending public money. It was found that an important task of the state and its bodies is: first, to create a transparent system of tendering and public procurement; second, strict control over how these funds are used, in what directions, and so on. It was concluded that counteracting corruption should include: 1) legal measures, the creation of an appropriate legal field to prevent corruption by officials; 2) organizational and administrative measures; 3) improvement of personnel, logistical and financial support of the authorized bodies of state power; 4) active involvement of the public in anti-corruption activities.

Key words: corruption, counteraction to corruption, conceptual foundations, fiscal policy, staffing, government revenues, state expenditures.

Постановка проблеми. Сьогодні Україна знаходиться на важливому етапі свого розвитку, що вимагає від законодавця рішучих реформаторських дій у всіх сферах суспільного життя. Одним із таких напрямів є якісне та ефективне покращення фіскальної політики. Варто зазначити, що протягом останніх років вчені по-різному підходили до проблеми удосконалення фіскальної політики в Україні. Кожен із них вказував на окремі напрями їі подальшого розвитку, однак при цьому єдиної, цілісної концепції подальшого розвитку цього інституту так сформовано і не було. Отже, ми, розмірковуючи про вектори розвитку фіскальної політики в Україні в умовах Свроінтеграції, дійшли висновку, що їх найбільш доцільно поділити залежно від того, з яких складників утворюється фіскальна політика, а саме: 1) удосконалення системи державних доходів, зокрема за рахунок покращення податкової сфери; 2) удосконалення системи державних витрат; 3) забезпечення ефективної протидії корупції на всіх стадіях формування бюджету та використання бюджетних коштів. На жаль, рамки представленої статті не дають змогу змістовно розкрити всі окреслені напрями, а тому ми приділимо увагу останньому, а саме проблемі протидії корупції у вказаній сфері суспільних відносин. Адже протягом останніх років це негативне явище охопило фактично всі сфері суспільного життя, що призводить до «отруєння суспільства» та його зубожіння.

Аналіз останніх досліджень і публікацій. Окремі проблемні питання щодо удосконалення формування та реалізації фіскальної політики в Україні в своїх наукових дослідженнях розглядали такі вчені, як І. Череда, О. Ракул, Г. Ляхович, Л. Михайлишин, І. Пилипів, О. Майстренко М. Кучерявенко, Г. Бех, В. Андрущенко, Т. Меркулова, М. Гридчина, Д. Кобильнік, В. Тропина, Н. Вдовиченко В. Білоцерківець, Я. Жаліло, О. Дмитрик, А. Крисоватий, С. Маслюченко, Я. Литвиненко та багато інших. Однак, незважаючи на чималу кількість наукових розробок, вчені невиправдано мало уваги приділяли питанню подолання та протидії корупції як важливій концептуальній засаді удосконалення фіскальної політики в Україні в умовах євроінтеграції.

Мета статті - розглянути проблему подолання корупції в Україні в контексті розробки концептуальних засад удосконалення фіскальної політики в нашій державі.

Виклад основного матеріалу. Корупція - це одне із явищ, які здатні породжувати кризові стани у різних галузях суспільного та соціального розвитку кожної держави, насамперед це стосується політики, економіки, державного управління, а також є однією із ключових передумов існування організованої злочинності. Отже, знання природи, причин виникнення та умов, що сприяють існуванню корупції в реаліях сьогодення, дасть змогу запровадити заходи, які повинні обмежити можливості іiї подальшого розповсюдження та негативного впливу на розвиток України [1, с. 14]. Корупція відома з давніх часів. Як свідчать історичні джерела, вона виникла разом $з$ появою держави та створенням органу, наділеного владно-управлінськими повноваженнями [2; 1, с. 14]. За всіх часів свого існування, підкреслює О.В. Ткаченко, це явище має характерні особливості - воно є шкідливим в правовому, соціальному, економічному, управлінському, моральному та інших аспектах [1, с. 14]. Протягом багатьох років в юридичній літературі склалось досить багато підходів щодо визначення поняття «корупція».

ISSN 2521-6473

Правова позиція, № 3 (24), 2019 
Так, Великий тлумачний словник сучасної української мови подає кілька визначень «корупція», а саме: 1) корупція - це діяльність осіб, уповноважених на виконання функцій держави, спрямована на протиправне використання наданих їм повноважень для одержання матеріальних благ, послуг та інших переваг; 2) корупція - це пряме використання посадовою особою свого службового становища 3 метою особистого збагачення; 3) корупція - підкупність, продажність урядовців і громадських діячів [3, с. 489]. Автори посібника «Запобігання і протидія проявам корупції як елемент модернізації системи державної служби» зазначають, що корупція - це складне і багатоаспектне (економічне, політичне, правове, морально-психологічне) соціальне явище, змістом якого $є$ зумовлена політичними, економічними, соціальними і психологічними факторами система негативних поглядів, переконань, установок і діянь посадових осіб інститутів влади, державних і недержавних організацій, політичних партій, громадських організацій, спрямованих на задоволення особистих, корисливих, групових або корпоративних інтересів шляхом підкупу, хабарництва, зловживання владою, надання пільг і переваг всупереч суспільним інтересам. ІЇ̈ соціальна сутність проявляється в тому, що вона: має соціальну зумовленість (є продуктом соціального життя); має свою соціальну ціну, яку платить суспільство за існування корупції; істотно впливає на найважливіші соціальні процеси; має історичні витоки і глобальний характер; є економічним, політичним, правовим, психологічним і моральним явищем; має властивість пристосовуватись до соціальних реалій, постійно міркувати та видозмінюватися [4, с. $13 ; 5]$.

M.I. Мельник визначає корупцію як правову категорію, зазначаючи, що корупція - це соціальне явище, яке охоплює всю сукупність корупційних діянь, пов'язаних з неправомірним використанням особами, уповноваженими на виконання функцій держави, наданої їм влади, посадових повноважень, відповідних можливостей з метою задоволення особистих інтересів чи інтересів третіх осіб, а також інших корупційних правопорушень, які створюють умови для вчинення корупційних діянь чи $є$ приховуванням їх або потуранням їм [6, с. 135; 7]. Г. Аврек та В. Овчинський пропонують розуміти корупцію як форму службового зловживання, в якому завжди наявна пряма чи завуальована корислива мета. Вони стверджують, що корупція пов'язана $з$ підкупом осіб, які перебувають на державній або громадській службі, одержанням ними додаткових доходів, благ і переваг за вчинення умисних дій або бездіяльності (у тому числі в інтересах третіх осіб) всупереч інтересам держави і суспільства [8, с. 105].

Таким чином, незважаючи на все різноманіття підходів науковців щодо визначення поняття «корупція», беззаперечним та неоспорюваним $\epsilon$ той факт, що це явище $\epsilon$ винятково негативним, незалежно від того, у якій сфері суспільного життя воно виникає. Варто вказати, що протягом останніх років рівень корупції в нашій державі неухильно зростає. Так, за 2018 рік Україна піднялася на 10 позицій у рейтингу «Індекс сприйняття корупції» (показник, який з 1995 року розраховується Transparency International на основі 13 досліджень авторитетних міжнародних установ і дослідницьких центрів), посівши 120-е місце серед 180 країн. Серед сусідів гірші показники тільки у Росії [9]. А отже, на цей час важливим завданням держави $є$ протидія корупції, яку у наукових колах розглядають у широкому та вузькому значеннях. Так, у широкому розумінні протидія корупції - це будь-яка діяльність у сфері соціального управління, яка, не переслідуючи спеціальної мети, сприяє зменшенню можливостей для корумпування суспільних відносин, зокрема, шляхом забезпечення верховенства права, реалізації інших принципів права, розвитку демократичного суспільства та утвердження правової держави [10]. У вузькому розумінні протидія корупції - це система заходів політичного, правового, організаційно-управлінського, ідеологічного, соціально-психологічного та іншого характеру, що мають цільове спрямування на зменшення обсягів корупції, зміну характеру корупційних проявів, обмеження взаємовпливу корупції та інших соціальних явищ і проце- 
сів, збільшення ризику для осіб, які вчиняють корупційні правопорушення, нейтралізацію дії та усунення факторів корупції, виявлення, припинення та розслідування проявів корупції, притягнення винних у вчиненні корупційних правопорушень осіб до юридичної відповідальності, поновлення законних прав та інтересів фізичних і юридичних осіб, усунення наслідків корупційних діянь. Протидія корупції є безпосереднім виразом антикорупційної політики, яка визначає ідеологію і стратегію антикорупційних заходів [10].

Варто зазначити, що протидія корупції в рамках удосконалення фіскальної політики України в умовах Євроінтеграції має здійснюватись у двох напрямах: перший - протидія корупції в органах Державної податкової служби (під час формування державного бюджету за рахунок сплати податків); другий - протидія корупції під час витрати державних коштів. В контексті першого напряму слід вказати думку І.П. Петрової, яка, досліджуючи проблему корупції в органах ДПС, дійшла слушного висновку, що «протидія корупції в діяльності Державної податкової служби України являє собою специфічний різновид суспільної діяльності, змістом якої є розробка та реалізація комплексу заходів політико-правового, соціально-економічного, організаційно-управлінського, культурно-виховного та іншого характеру, спрямованих на виявлення і ліквідацію проявів корупції в діяльності структурних підрозділів ДПС всіх рівнів, усунення їх негативних наслідків та притягнення до відповідної юридичної відповідальності винних у вчиненні корупційних дій осіб, а також на встановлення та ліквідацію умов, обставин і факторів, що прямо чи опосередковано сприяють розвитку корупції в системі ДПС України [11, с. 221]. Тобто протидія корупції - це комплексний механізм, що будується на певних принципах та відповідно до вимог чинного законодавства має свій суб'єктно-об'єктний склад та відповідні інструменти, тобто форми, методи, способи та засоби протидії корупції. Головною метою протидії корупції, зазначає І.П. Петрова, має стати створення такого політико-правового, соціально-економічного та морально-психологічного клімату в середині системи ДПС України, який би був максимально несприятливим для процвітання корупції та мінімізував вірогідність вчинення посадовими особами Державної податкової служби України [11, с. 221]. Тобто у такому разі протидія корупції у діяльності ДПС сприятиме тому, що, по-перше, працівники фіскальної служби будуть чесно виконувати свої посадові обов'язки, що надалі сприятиме покращенню якості та ефективності роботи ДПС взагалі, а по-друге, зниження рівня корупції або ж ііі повне подолання призведе до того, що всі кошти будуть потрапляти до державного бюджету України, що своєю чергою дозволить подолати бюджетний дефіцит, а також повною мірою виконати обов'язки за чисельними міжнародними кредитами.

Що ж стосується протидії корупції під час витрат грошових коштів уповноваженими на те суб'єктами, то вона найчастіше проявляється у тому, що розпорядники досить часто нехтують правилами проведення тендерів, державних закупівель тощо. Адже нерідкими є випадки, коли товари за державний кошт закуповуються за вищою ціною, аніж вона є на ринку. Так, на початку 2019 року виникла ситуація, коли керівники Харківського зоопарку здійснювали закупівлю бананів, ананасів та інших фруктів для тварин за ціною, яка в декілька разів перевищувала вартість їх у звичайному супермаркеті. У такому випадку ми маємо такий прояв корупції, як «відкат». Саме тому важливим завданням держави та ії органів $є$ : по-перше, створення прозорої системи ведення тендерів та державних закупівель; по-друге, здійснення суворого контролю за тим, як використовуються ці кошти, за якими напрямами тощо.

Як окремий напрям протидії корупції слід вказати необхідність покращення взаємодії між органами ДПС, НАБУ та іншими уповноваженими суб'єктами. В цьому контексті слід вказати точку зору, яку у своєму інтерв’ю висловив Виконавчий директор «Трансперенсі Інтернешнл Україна» Андрій Боровик, який щодо виходу України із «клубу корумпованих країн» зазначив: «Необхідно надати НАБУ права самостійно здійснювати прослуховування, без СБУ.

ISSN 2521-6473

Правова позиція, № 3 (24), 2019 
Натомість позбавити Службу безпеки будь-яких повноважень у сфері боротьби з корупцією та економічними злочинами. Нехай займаються контррозвідкою і захистом державності. Ми радимо повністю перезапустити НАЗК - змінити модель управління, провести відкритий конкурс (з мінімальним політичним впливом) на керівні посади, набрати новий персонал. Повинні запрацювати автоматична перевірка декларацій та моніторинг рівня життя держслужбовців. Ми бачимо простір для вдосконалення системи публічних закупівель ProZorro». А. Боровик також підтримує законопроект, який для цього підготувало профільне міністерство: «Варто посилити контроль за фінансами політичних партій, їхня фінансова звітність має бути переведена в електронний формат. Безперечно, правоохоронні органи повинні захистити антикорупційних активістів та журналістів-розслідувачів від тиску та нападів і нарешті скасувати дискримінаційне обов'язкове декларування антикорупціонерів» [12]. Із вказаною пропозицією складно не погодитись.

Висновки 3 дослідження і перспективи подальших розвідок у цьому напрямі. Завершуючи розгляд питання протидії корупції в рамках удосконалення фіскальної політики в Україні в умовах євроінтеграції, можна із впевненістю констатувати, що в сучасних реаліях, яких опинилась наша країна, саме протидія вказаному негативному соціальному явищу має займати одне із найбільш пріоритетних місць в концепції покращення сучасної фіскальної політики України. На наш погляд, протидія корупції повинна включати: 1) правові заходи, тобто створення відповідного правового поля для попередження вчинення корупційних діянь посадовими особами; 2) організаційно-управлінські заходи, які передбачають: а) проведення моніторингу рівня життя посадових осіб; б) оперативне реагування на скарги щодо виявлення фактів вчинення корупційних правопорушень; в) перегляд системи декларування доходів посадових осіб та їх родичів; 3) покращення кадрового, матеріально-технічного та фінансового забезпечення уповноважених органів державної влади, як тих, що відповідають за поповнення та витрати державного бюджету, так і тих, що уповноважені здійснювати антикорупційні заходи; 4) активне залучення громадськості до антикорупційних заходів;

\section{Список використаних джерел:}

1. Ткаченко О.В. Адміністративно-правові засади протидії корупції в органах внутрішніх справ [Текст] : дис... канд. юрид. наук: 12.00 .07 ; Київський національний ун-т внутрішніх справ. Навчально-науковий ін-т підготовки кадрів громадської безпеки та психологічної служби. Київ, 2008. 208 арк.

2. Александровская С.В. Марк Туллий Цицерон: Концепция борьбы с коррупцией. Юристъ-Правоведъ, 2003. № 2 (7). С. 60-65.

3. Великий тлумачний словник сучасної мови / уклад. і голов. ред. В.Т. Бусел. Київ : ВТФ Перун, 2003. С. 489

4. Запобігання і протидія проявам корупції як елемент модернізації системи державної служби / Івано-Франківський центр науки, інновацій та інформатизації. Івано-Франківськ: 2012. c. 237

5. Добровольський О.І. Адміністративно-правове регулювання протидії корупції в органах державної фіскальної служби України : дис. канд. юр. наук : УДК 342.9 (477). Добровольський Олег Ігорович - Київ, 2015. 201 с.

6. Мельник М.І. Корупція: сутність, поняття, заходи протидії : монографія. Київ : Атіка, 2001. $304 \mathrm{c}$.

7. Бойко А.М. Теорія детермінації економічної злочинності в Україні в умовах переходу до ринкової економіки. : дис... д-ра наук : 12.00.08. 2010. 492 с. 
8. Аврек Г., Овчинський В. Мздоимство и лихоимство на переходе к рынку. Наш современник. 1992. № 2. С. 105.

9. Рейтинг сприйняття корупції: Україна вже вище, але досі відстає від сусідів / BBC NEWS Україна. URL: https://www.bbc.com/ukrainian/news-47038933.

10. Мельник М.I. Кримінологічні та кримінально-правові проблеми протидії корупції [Текст] : дис... д-ра юрид. наук: 12.00.08 / Мельник Микола Іванович ; Національна академія внутрішніх справ України. Київ, 2002. 506 арк.

11. Петрова І.П. Протидія корупції в діяльності Державної Фіскальної служби України. URL: http://www.pap.in.ua/5_2016/66.pdf.

12. «Індекс сприйняття корупції»: Україна дещо зміцнила позиції / Офіційний веб-сайт «Paдiо Свобода». URL: https://www.radiosvoboda.org/a/29735869.html. 
УДК 351.74:331.36

DOI https://doi.org/10.32836/2521-6473-2019-3-90-94

\author{
О. П. Цуркан, здобувач кафредри \\ адміністративно-правових дисциплін, \\ викладач кафедри \\ тактико-спеціальних дисциплін факультету № 1 \\ Донецького юридичного інституту МВС України
}

\title{
МЕТА ПРОФЕСІЙНОГО НАВЧАННЯ ПОЛІЦЕЙСЬКИХ УКРАЇНИ
}

У статті проводиться вивчення поняття «мета професійного навчання полічейських Украӥні». Висвітлені основні погляди науковців та нормативні джерела, що визначають особливості організації різновидів професійного навчання та підготовки полічейських. Зокрема, виявлено, що серед діючих документів лише Положення про організацію первинної професійної підготовки поліщейських має визначення поняття «мета» зазначеного процесу. Решта нормативно-правових актів поняття «мета професійного навчання полічейських» не розкривають, що призводить до наявності низки різноманітних поглядів і тому потребує уточнення. На підставі проведеного аналізу пропонуємо поняття «мета професійного навчання полічейських» викласти таким чином - безперервний процес набуття та вдосконалення професійних знань, умінь та навичок суб'єктами професійного навчання, здатних забезпечити відповідний рівень їх професійної кваліфікації для подальшої оперативно-службової діяльності, у тому числі відповідну спеціальну підготовку щодо зберігання, носіння, застосування і використання вогнепальної зброї. Сформована мета повністю надає розуміння очікуємого результату всіх видів реалізації професійного навчання полічейських України, а саме: первинній професійній підготовиі; підготовиі у вищих навчальних закладах із спеиифічними умовами навчання; післядипломній освіті; службовій підготовиі тощо. Запропоноване авторське визначення поняття «мета професійного навчання поліцейських» надане для узагальнення в нормативно-правових актах Національної поліиії України і подальшого застосування в наукових дослідженнях.

Ключові слова: Міністерство внутрішніх справ України, Національна полічія України, поліцейський, професійне навчання, нормативно-правовий акт, положення.

\section{O. P. Tsurkan. The purpose of professional training the police officers of Ukraine}

The opportunity of obtaining education is considered as an inalienable right of the subjects of a developed society. There is a component of the effectiveness of public life, the performance of socially useful functions by its representatives. However, in this context, the acquisition of educational levels should not be limited to a quantitative indicator of acquired knowledge of people or the level of literacy of the population. When it has the conditions of Ukraine's integration into the European Community and the implementation of reforms, especially in the police, the training of highly skilled specialists for all units is a topical issue. That is why the quality and effectiveness of the training process, the ability of the police to master and use the acquired knowledge in duty for the protection of public order and safety are the main goal of professional training of the police officers in Ukraine.

We believe that the primary goal of professional training of Ukrainian police officers is to formulate a comprehensive police development, when the latter will be interested and focused on further improving its educational and professional level, and the acquired knowledge, skills and these skills will contribute to self-improvement and career growth. On the other hand the professional training of police officers, including the Ministry of Internal Affairs departmental education system, should aim at ensuring that the knowledge gained a foundation for the formation of their own views, legal education and proper ethical behavior. It also helped to understand the policeman's place in society and the amount of responsibility according to the position occupied. It should be noted that the presence of such a multifaceted process as professional training, including policemen, is an obvious indication of the true direction of the reforms that are taking place on the territory of Ukraine and are essential for the formation of civil society.

(C) О. П. Цуркан, 2019 
So, we made a statement, that the purpose of professional training of police officers is the standing process of getting and improving professional knowledge, skills and abilities of staff of professional training. There are faculties of providing the appropriate level of their professional qualification for further operational-service duties and activities, including appropriate special training on carrying and using of firearms.

And in our opinion, the purpose of professional training of the police officers of Ukraine is fully reveals all the main tasks the types of training as: primary vocational training; training in higher education institutions with specific learning conditions; postgraduate education; service training, etc.

Key words: Ministry of Internal Affairs of Ukraine, National Police of Ukraine, police officer, professional training, regulatory act, regulations.

Постановка проблеми. Можливість здобуття освіти розглядається як невіддільне право суб'єктів розвинутого громадянського суспільства, а також як складник ефективності суспільного життя, виконання суспільно-корисних функцій його представниками. Однак у цьому контексті отримання освітніх рівнів не має обмежуватись лише кількісним показником набутих особами знань чи рівнем грамотності населення. Адже в умовах інтеграції України в Свропейське співтовариство і проведення реформ, зокрема в поліції, підготовка висококваліфікованих фахівців для усіх підрозділів $\epsilon$ нагальним питанням. Саме тому якість і результативність навчального процесу, здатність поліцейських до засвоєння та використання набутих знань під час вирішення службово-бойових завдань з охорони публічного порядку і безпеки є головною метою професійного навчання поліцейських України, до розгляду якої ми безпосередньо перейдемо.

Аналіз останніх досліджень та публікацій. Дослідженню мети професійної підготовки фахівців різних галузей, в тому числі мети професійного навчання поліцейських, свого часу були присвячені наукові праці таких вчених, як М.I. Ануфрієва, О.М. Бандурки, В.А. Глуховері, І.В. Зозулі, О.С. Користіна, З.Н. Курлянд, О.В. Негодченко, А.М. Подоляки, І.М. Шопіної, О.Н. Ярмиша та інших. Але переважно їх здобутки були зроблені до прийняття Закону України «Про Національну поліцію» від 02 липня 2015 року, і саме тому зазначене питання потребує деталізації.

Результати викладу основного матеріалу. Вивчаючи тлумачення терміну «мета» ми звернулись до офіційного інтернет-видання, що розкриває термінологію української мови. Так, словник української мови визначає мету як «те, до чого хтось прагне, чого хоче досягти; ціль» [1].

Під час здійснення аналізу наукових праць знаходимо власні розуміння вченими зазначеного питання. Зокрема, О.П. Єгоршин розкриває мету професійної підготовки, що є тотожним поняттям «професійного навчання», як процес, що здійснюється з метою одержання певної професії або спеціальності тим чи іншим працівником і обов'язково передбачає різні рівні підготовки [2].

Доповнюючи це визначення, ряд російських науковців (зокрема у сфері гірничої справи, такі як Квагінідзе В.С. і Козлов В.А.) з посиланням на закон Російської Федерації «Про освіту» вказують, що професійна підготовка має на меті прискорене отримання особами, що навчаються, навичок, необхідних для виконання визначеної роботи, групи робіт. Саме тому професійна підготовка може бути отримана в освітніх закладах навчальної професійної освіти, а також в освітніх підрозділах організацій, що мають відповідні ліцензії [3, с. 10].

Українські ж вчені, зокрема I.М. Шопіна, зазначають, що «мета професійної підготовки формується зовні системи освіти, зумовлена потребами суспільства та особистості та являє собою «замовлення» на підготовку спеціалістів. До того ж професійна підготовка повинна віддзеркалювати не лише сучасний стан науки, техніки, виробництва, суспільних відношень, а й перспективу їх розвитку. Формування мети професійної підготовки має починатися з визначення вимог практичної діяльності та трансформації їх в педагогічні цілі» [4].

О.С. Користін наголошує на співіснуванні поліцейської підготовки та поліцейської освіти. Спираючись на праці німецького дослідника Пітера Доома, науковець вважає, що для

ISSN 2521-6473

Правова позиція, № 3 (24), 2019 
поліції необхідно готувати і фахівців широкого профілю, і фахівців вузької спеціалізації. Констатуючи при цьому, що нині в поліцейській діяльності котирується не горезвісна робоча сила, а працівник з високим рівнем освіченості, вихованості, професійної навченості, сукупність чого і формує професіоналізм. Саме тому, за визначенням О.С Користіна, мета професійної поліцейської освіти - готувати поліцейських-професіоналів будь-якого рангу і для будь-якого виду поліцейської діяльності [5].

3.Н. Курлянд своєю чергою вказує, що мета професійної освіти - загальний і професійний розвиток особистості, становлення її професійної культури. Адже незалежно від того, кого готують професійні навчальні заклади, яку освіту (середню, вищу) вони надають, головним є рівень загальної та професійної освіти і професійного розвитку, який ці заклади забезпечують. Додатково науковець наголошує на необхідності тісного зв'язку середньої, професійно-технічної вищої та післядипломної освіти, що є запорукою реалізації безперервної освіти, освіти впродовж життя, яка має задовольняти потреби особистості в підвищенні кваліфікації чи здобуття нової професії [6].

Державні ж нормативно-правові акти, що регулюють галузь професійного навчання в Україні, містять різні тлумачення мети професійного навчання. Так, наприклад, Розпорядження Кабінету міністрів України від 17 липня 2003 року №436 «Про затвердження Концепції оптимізації підготовки кадрів та організації надання освітніх послуг у навчальних закладах Міністерства оборони, інших центральних органів виконавчої влади, що здійснюють керівництво військовими формуваннями і правоохоронними органами» розкриває мету оптимізації існуючої системи підготовки фахівців як підвищення їх професійного рівня, раціональне використання коштів державного бюджету, що виділяються для такої підготовки, та приведення іiі кількісних і якісних показників у відповідність до завдань, структури і чисельності Збройних Сил, інших військових формувань і правоохоронних органів [7]. Іншим документом, а саме Постановою Кабінету міністрів України від 06 лютого 2019 року № 106 «Про затвердження Положення про систему професійного навчання держаних службовців, голів місцевих держаних адміністрацій, ïx перших заступників та заступників, посадових осіб місцевого самоврядування та депутатів місцевих рад» окреслено перелік термінів, що розкривають особливості системи професійного навчання, зокрема, й мету професійного навчання як процес набуття та вдосконалення професійних знань, умінь та навичок учасників професійного навчання, що забезпечує відповідний рівень їх професійної кваліфікації для їх професійної діяльності [8]. А в ст. 8 Закону України «Про зайнятість населення» від 05 липня 2012 року зазначено, що кожен має право на професійне навчання, метою якого є здобуття особою відповідної кваліфікації або приведення ііі рівня у відповідність до вимог сучасного виробництва та сфери послуг [9].

Враховуючи особливий статус державних службовців, в «Положенні про організацію первинної професійної підготовки поліцейських, яких вперше прийнято на службу в поліції» викладено, що поліцейські, яких вперше прийнято на службу в поліції, проходять професійну підготовку з метою набуття ними спеціальних навичок, необхідних для виконання повноважень поліції, у тому числі відповідну спеціальну підготовку щодо зберігання, носіння, застосування і використання вогнепальної зброї [10]. Метою ж післядипломної освіти як виду професійного навчання поліцейських є задоволення індивідуальних потреб працівників поліції в особистому професійному зростанні, забезпечення потреб держави у кваліфікованих кадрах високого рівня професіоналізму та культури, здатних компетентно і відповідально виконувати свої функції [11].

На відміну від зазначених Положень, Наказом Міністерства внутрішніх справ України від 14 лютого 2008 року № 62 визначена лише мета діяльності закладів вищої освіти шляхом забезпечення умов, необхідних для отримання особою вищої освіти, підготовки фахівців для 
органів і підрозділів Міністерства внутрішніх справ України, інших органів виконавчої влади, підприємств, установ та організацій України [12]. Проте саме мета професійної підготовки поліцейських в закладах вищої освіти Міністерства внутрішніх справ України не розкрита, що призводить до наявності низки різноманітних наукових поглядів на зазначене питання і потребує уточнення. Аналогічна ситуація спостерігається і в таких нормативно-правових документах, як Положення про організацію службової підготовки працівників Національної поліції України та Законі України «Про Національну поліцію», в яких розкривається лише поняття службової підготовки як системи заходів, спрямованих на закріплення та оновлення необхідних знань, умінь та навичок працівника поліції з урахуванням оперативної обстановки, специфіки та профілю його оперативно-службової діяльності [13; 14]. Однак мета безпосередньо службової підготовки законодавчо не визначена, а випливає лише з іï суті.

Висновки 3 дослідження і перспективи подальших розвідок у цьому напрямі. Таким чином, спираючись на погляди науковців та чинні нормативно-правові акти, ми вважаємо, що першочерговою метою професійного навчання поліцейських України є формування всебічного розвитку поліцейського, коли останній буде зацікавлений та орієнтований на подальше підвищення свого освітнього і професійного рівня, а отримані знання, уміння та навички сприятимуть самовдосконаленню і кар'єрному зростанню. Одночасно з цим професійне навчання поліцейських і система відомчої освіти Міністерства внутрішніх справ України мають бути спрямовані на те, щоб отримані знання заклали підгрунтя формування власних поглядів, правової освіченості та належної етичної поведінки, а також сприяли розумінню поліцейським свого місця в суспільстві та обсягу відповідальності відповідно до займаної посади. Адже слід зазначити, що наявність такого багатогранного процесу, як професійне навчання, в тому числі поліцейських, є очевидним свідченням вірного напряму реформ, що проводяться на території України і $є$ нагальними для формування громадянського суспільства.

Саме тому аналіз наведених джерел надав можливість сформулювати зазначене поняття. Отже, мета професійного навчання поліцейських - безперервний процес набуття та вдосконалення професійних знань, умінь та навичок суб'єктами професійного навчання, здатних забезпечити відповідний рівень їх професійної кваліфікації для подальшої оперативно-службової діяльності, у тому числі відповідну спеціальну підготовку щодо зберігання, носіння, застосування і використання вогнепальної зброї.

На нашу думку, сформульована нами мета професійного навчання поліцейських України повністю розкриває всі основні завдання, що закладені в основних видах іiі реалізації, а саме: первинній професійній підготовці; підготовці у вищих навчальних закладах із специфічними умовами навчання; післядипломній освіті; службовій підготовці тощо.

\section{Список використаних джерел:}

1. Словник української мови : в 11 томах. АН УРСР. Інститут мовознавства. За ред. I.К. Білодіда. Київ : Наукова думка. 1970-1980. Т. 4. С. 683. URL: http://ukrlit.org/slovnyk/ slovnyk_ukrainskoi_movy_v_11_tomakh/\%D0\%BC\%D0\%B5\%D1\%82\%D0\%B0 (дата звернення 20.07.2019).

2. Егоршин А.П. Управление персоналом. Н. Новгород : НИМБ, 1999. с. 122.

3. Квагинидзе В.С., Козлов В.А., Петров В.Ф., Кожевников В.В.. Профессиональная подготовка кадров на производстве. Москва : Издательство Московского государственного горного университета. 2003. Ст. 263.

4. Шопіна I.M. Правові та організаційні засади підвищення ефективності професійної діяльності слідчих органів внутрішніх справ України : дис. ... канд. юрид. наук : 12.00.07. Харків. 2004. С. 148. 
5. Користін О.Є. ПРОФЕСІЙНА ОСВІТА ПОЛЦЕЙСЬКОГО: В ЯКОМУ НАПРЯМУ PУХАТИСЬ? URL: politrada.org/news/profes-yna-osv-ta-pol-tseyskogo-v-yakomu-napryamkurukhatis/ (дата звернення 20.07.2019).

6. Теорія і методика професійної освіти : навч. посіб. 3.Н. Курлянд [та ін.]. за ред. 3.Н. Курлянд. Київ. Знання. 2012. Ст. 390.

7. Про затвердження Концепції оптимізації підготовки кадрів та організації надання освітніх послуг у навчальних закладах Міноборони, інших центральних органах виконавчої влади, що здійснюють керівництво військовими формуваннями і правоохоронними органами: Розпорядження Кабінету Міністрів України від 17 липня 2003 р. № 436. Офіиійний вісник України від 08 серпня 2003 року № 30, Ст. 222.

8. Про затвердження Положення про систему професійного навчання держаних службовців, голів місцевих держаних адміністрацій, їх перших заступників та заступників, посадових осіб місцевого самоврядування та депутатів місцевих рад: Постанова Кабінету міністрів України від 06 лютого 2019 року № 106. Офіційний вісник України від 07 березня 2019 року № 19. Ст. 43.

9. Про зайнятість населення: Закон України від 07 липня 2012 року № 5067-VI. Відомості Верховної Ради України від 14 червня 2013 року № 24, Ст. 1284.

10. Про затвердження Положення про організацію первинної професійної підготовки поліцейських, яких вперше прийнято на службу в поліції: Наказ Міністерства внутрішніх справ України від 16 лютого 2016 року №105. Офіційний вісник України від 14 травня 2016 року. № 35 . Ст. 81.

11. Про затвердження Положення про організацію післядипломної освіти працівників Національної поліції: Наказ Міністерства внутрішніх справ України від 24 грудня 2015 року № 1625. Офіиійний вісник Украӥни від 16 лютого 2016 року. № 11. Ст. 173.

12. Про затвердження Положення про вищі навчальні заклади МBC: Наказ Міністерства внутрішніх справ України від 14 лютого 2008 року № 62. Офіиійний вісник України від 28 березня 2008 року. № 21. Ст. 112.

13. Про затвердження Положення про організацію службової підготовки працівників Національної поліції України: Наказ Міністерства внутрішніх справ України від 21 січня 2016 року №50. Офічійний вісник Украӥни від 25 березня 2016 року. № 22. Ст. 42.

14. Про Національну поліцію: Закон України від 02 липня 2015 року № 580-VIII. Biдомості Верховної Ради Украӥни. Офіційне видання від 09 жовтня 2015 року. № 40-41. Ст. 1970. 
УДК 347.4

DOI https://doi.org/10.32836/2521-6473-2019-3-95-101

\author{
П. Д. Гуйван, кандидат юридичних наук, \\ заслужений юрист України, професор \\ Полтавського інституту бізнесу
}

\title{
УКРАЇНСЬКЕ ТА МІЖНАРОДНЕ ПРАВОВЕ ОПОСЕРЕДКУВАННЯ ДОСТУПУ ОСОБИ ДО ІНФОРМАЦІї
}

У иій роботі проведений науковий аналіз актуальних питань, пов'язаних із юридичним забезпеченням конституціийного права особи на доступ до інформації, яка має суспільний інтерес. При иьому доступ має бути гарантований саме публічними суб' єктами, які здійснюють створення та зберігання такої інформачії. На них покладається позитивний обов'язок оприлюднювати інформацію, щчо має ознаки публічної, та безперешкодно надавати доступ до таких відомостей, якщо у запитувача є законні підстави для отримання такого доступу. Вивчено низку міжнародних та національних нормативних актів, які визначають характер поведінки учасників відносин щодо доступу до публічної інформації. Визначено, що міжнародний акт - Рекомендачії Ради Європи R (2002)2 «Про доступ до офіційних документів» - розглядає право на доступ до інформачії насамперед як складову частину загального інформачійного статусу людини в демократичному суспільстві. Такий підхід покликаний забезпечити повну реалізаиію потреб у необхідних відомостях про обставини зовнішнього та внутрішнього світогляду конкретної особистості.

Проаналізовано основні украӥнські правові документи, які регулюють питання доступу до публічної інформації, визначають права та обов'язки, як осіб, щяо запитують певні публічні відомості, так і посадовиів, котрі мусять надавати такі відомості. Встановлено відсутність у чинному національному законодавстві чітких механізмів, які б конкретизували та деталізували порядок застосування загальних правил щодо доступу до інформачії в окремих сферах матеріальних відносин. Визначено, що у діяльності органів публічної влади та місиевого самоврядування у процесі реалізачії права доступу до публічної інформації немає чіткого механізму його забезпечення, їх діяльність має декларативні положення щзодо обміну інформацією, які потребують використання сучасної інформаційної та управлінської технологій, єдиних стандартів якості для надання інформаџійних та інших послуг громадськості.

Досліджена проблематика стосовно втілення у вітчизняному правовому середовищі міжнародного принципу стимулювання відкритого уряду. Публічність діяльності повинна проявлятися в інформуванні громадян про їхні права і у такий спосіб сприяти культурі відкритості органів влади. Наведені типові зловживання з боку влади правом особи на вільний доступ до інформаиії.

Ключові слова: публічна інформація, вільний доступ, відкритість влади.

\section{P. D. Guyvan. Ukrainian and international legal mediation of a person's access to information}

In this work, a scientific analysis of current issues related to the legal support of the constitutional right of a person to access information of public interest is carried out. Moreover, access should be guaranteed precisely by public entities involved in the creation and storage of such information. They have a positive obligation to disclose information that has signs of publicity and to freely provide access to such information if the requesting entity has legal grounds for obtaining such access. A number of international and national normative acts have been studied that determine the behavior of participants in relations regarding access to public information. It is determined that the international act - Council of Europe Recommendations $R$ (2002) 2 "On access to official documents" considers the right to access information, first of all, as an integral part of the general informational status of a person in a democratic society. This approach is designed to ensure the full implementation of the needs for the necessary information about the circumstances of the external and internal worldview of a particular person.

The author analyzes the main Ukrainian legal documents regulating access to public information, defining the rights and obligations of both the person who requests certain public information and the officials who

(C) П. Д. Гуйван, 2019

ISSN 2521-6473

Правова позиція, № 3 (24), 2019 
must provide such information. The absence of clear mechanisms in existing national legislation that would specify and detail the application of general rules for access to information in certain areas of material relations was established. It was determined that in the activities of public authorities and local self-government in the process of exercising the right of access to public information there is no clear mechanism for its provision, their activities have declarative provisions for the exchange of information, which require the use of modern information and management technologies, common quality standards to provide information other public services.

The problems of the implementation in the domestic legal environment of the international principle of stimulating an open government are investigated. The publicity of the activity should be manifested in informing citizens about their rights and thus contribute to a culture of openness of government. It is concluded that national legislation should carry out public education and disseminate information regarding the right to access information, determine the scope of information open for review and the ways in which this right can be realized. Typical abuses by the authorities of the human right to free access to information are given.

Key words: public information, free access, openness of power.

Постановка проблеми. В умовах стрімкого розвитку суспільної комунікації та сучасного соціального прогресу відбувається неухильне зростання значущості інформації, коли інформаційні відносини пронизують буквально всі сфери економіки, політики, соціального життя. В цьому сенсі правове опосередкування відносин, що відбуваються в сфері інформаційного обороту, набуває наразі неабиякої актуальності. Подальше просування будь-яких процесів у соціумі значною мірою залежить від належного стану інформаційної взаємодії окремих державних, громадських інституцій та фізичних осіб. Право особи на інформацію $\epsilon$ найважливішим органічним елементом загальної цілісної системи прав і свобод. Ступінь розвитку цього права характеризує значення прогресу самого суспільства, рівень особистої свободи особи, який реально забезпечується державою [1, с. 50]. Враховуючи значний попит на інформацію, важливість обороту у вказаній сфері, значних зусиль з боку правотворчої і правозастосовної гілок влади потребує організація належного правового забезпечення вказаних відносин. Це включає необхідність оформлення юридичних гарантій обігу інформації, обміну нею, шляхів удосконалення цього процесу, захисту носіїв інформації та осіб, котрі іії розповсюджують та використовують.

Одним з основних прав людини є можливість вільного доступу до інформації. Насамперед реалізація цього права досягається шляхом інформованості зацікавлених осіб про діяльність органів влади. Така інформація, яка має суспільний інтерес і $є$ публічною за своєю природою, крім суто пізнавального значення про соціально-політичну ситуацію в суспільстві, також може використовуватися для здійснення конституційного права громадян на участь у державному управлінні, підвищенні його якості, гарантування прозорості процедур прийняття управлінських рішень. Відкритість, публічність та прозорість діяльності суб'єктів владних повноважень, безумовно, сприяє створенню системи громадського контролю над діяльністю центральної і місцевої влади, спрямована на створення системи соціальної відповідальності управлінських суб'єктів. Нарешті відкритість процедур здійснення владних повноважень створює належні умови для протидії протиправним вчинкам, для боротьби з корупцією та правовим нігілізмом.

Аналіз останніх досліджень та публікацій. Питання правового забезпечення відкритості та вільного доступу до інформації досліджувалося у працях таких науковців, як Р. Головенко, А. Марущак, С. Янішевський, Е. Афонін, Н. Гудима, М. Демкова, С. Телешун, О. Кузьменко та інші. У вказаних роботах увага вчених була сконцентрована на різних аспектах забезпечення відкритості органів влади, з'ясовувалися питання юридичного оформлення можливості конкретної особи щодо доступу до публічної інформації. Водночас не напрацьовано єдиного правового підходу до визначення обов'язків окремих органів влади щодо надання запитуваної інформації, загальних правил стосовно обмеження невиправданої конфі- 
денційності, встановлення переліку публічних соціально важливих відомостей, які є необхідними для особи і дають можливість належно задовольнити ії публічний інтерес. Отже, метою цієї праці $є$ вивчення міжнародних та національних правових актів, що гарантують вільний доступ до інформації, відкритість у цьому сенсі державних та інших владних розпорядників, адаптуючи вказані підходи до національної системи права.

Виклад основного матеріалу. Світова доктрина та правотворча система напрацювали доволі усталені правила щодо гарантування кожній особі можливості отримати вільний доступ до інформації, яка перебуває у суб'єктів влади і становить певний суспільний інтеpec. У найбільш розгорнутому вигляді ці правила викладені у Рекомендаціях Ради Європи N R (2002)2 «Про доступ до офіційних документів» від 21 лютого 2002 року. Цей акт надає детальну характеристику та визначає порядок застосування таких норм основних міжнародних документів, як стаття 19 Загальної декларації прав людини, статті 6, 8 та 10 Конвенції Ради Європи «Про захист прав людини та основоположних свобод» 1950 року, Конвенція ООН «Про доступ до інформації, участь громадськості в процесі вироблення рішень та доступ до правосуддя в питаннях, коли йдеться про захист довкілля» від 25.06.1998 р., Конвенція РС N 108 від 28.01.1981 р. «Про захист осіб у зв'язку з автоматизованою обробкою персональних даних», Декларація «Про свободу вираження поглядів та інформації» від 28.01.1982 р., а також Рекомендація N R (81)19 «Про доступ до інформації, яка знаходиться в розпорядженні державних органів», Рекомендація N R (91)10 «Про передачу третім особам персональних даних, які знаходяться в розпорядженні державних органів», Рекомендація N R (97)18 «Про захист персональних даних, які збираються та записуються для статистичних цілей», Рекомендація N R (2000)13 «Про європейську політику доступу до архівів». Наголошується, що у демократичному суспільстві визначальним $є$ відкритість органів державної влади щодо інформації, яка становить суспільний інтерес.

Вказане завдання реалізується на основі рівноправності та відповідно до чітких правил, що дозволяє громадянам виробити адекватне бачення та сформувати критичні погляди щодо стану суспільства, у якому вони живуть, та щодо органів влади, які ними керують, сприяє більшій дієвості та ефективності адміністративних органів і допомагає підтримувати їх цілісність, усуваючи ризик корупції, є чинником, що підтверджує легітимність органів управління державних служб і посилює довіру громадськості до органів державної влади. Отже, державні органи повинні взяти на себе зобов'язання проводити активну політику в питаннях спілкування з громадянами 3 тим, щоб надати в розпорядження громадян всю інформацію, яка може вважатися необхідною у відкритому демократичному суспільстві [2].

В Україні головним документом, який визначає правові та організаційні умови здійснення конституційного права людини на доступ до соціально значимої інформації, є Закон України «Про доступ до публічної інформації». Цей нормативний документ передбачає право кожної особи на інформацію, при цьому одним з основних елементів інформаційної свободи визначається забезпечення доступу кожного до інформації. В цьому контексті цей Закон закріпив важливий принцип максимальної відкритості, згідно з яким будь-яка інформація є відкритою, крім тієї, що віднесена законом до інформації з обмеженим доступом. Наразі українське законодавство закріпило принцип, що грунтується на Конституції України, Цивільному кодексі України та міжнародних стандартах і передбачає, що інформація є об'єктом особистих немайнових прав, об’єктом особистих прав фізичної чи юридичної особи.

Попри те, що сьогодні в умовах технічного прогресу ведеться жвавий комерційний інформаційний обмін, і інформація, відтворена на певних паперових чи електронних носіях, все більше набуває ознак товару, суб'єкти владних повноважень, отримуючи чи створюючи інформацію, не набувають виняткових прав самостійного і безперешкодного розпорядження

ISSN 2521-6473

Правова позиція, № 3 (24), 2019 
нею на власний розсуд. Навіть більше, владна інституція лише виконує стосовно інформації певні, надані їй законодавчими актами, позитивні обов'язки, які полягають у оприлюдненні та наданні інформації на запит з метою реалізації права особи на доступ до інформації. Саме у такий спосіб владні структури здійснюють свої повноваження, зокрема, стосовно основоположного права на свободу інформації.

Закон України «Про доступ до публічної інформації» за ідеєю покликаний встановити порядок здійснення та забезпечення права кожного на доступ до інформації, яка знаходиться у володінні суб' єктів владних повноважень, інших розпорядників публічної інформації, визначених цим Законом, та інформації, що становить суспільний інтерес. Під публічною інформацією мається на увазі відображена та задокументована будь-якими засобами та на будь-яких носіях інформація, що була отримана або створена в процесі виконання суб'єктами владних повноважень своїх обов'язків, передбачених чинним законодавством, або яка знаходиться у володінні суб' єктів владних повноважень, інших розпорядників публічної інформації, визначених цим Законом.

Однак в національній публіцистичній літературі часто лунають обгрунтовані критичні висловлювання $з$ приводу того, що даний закон є лише декларацією, яка у практичній площині не здатна гарантувати реалізацію права на свободу інформації [3]. У діяльності органів публічної влади та місцевого самоврядування у процесі реалізації права доступу до публічної інформації немає чіткого механізму його забезпечення, їх діяльність має декларативні положення щодо обміну інформацією, які потребують використання сучасної інформаційної та управлінської технологій, єдиних стандартів якості для надання інформаційних та інших послуг громадськості [4, с. 218]. Значною мірою це так і $є$, бо спеціальний закон в принципі не здатен здійснити правового забезпечення усього комплексу питань, пов'язаних з доступом до інформації. Для цього, як в Свропі, мають бути розроблені численні підзаконні акти, які конкретизують і формалізують поведінку учасників відносин у кожній сфері суспільного життя, де потрібно забезпечити вільний доступ громадськості та конкретної особи до інформації. Поки що в даному напряму вітчизняне законодавство не рухається, що і призводить до поширення практики безпідставних відмов органів державної влади на звернення громадян щодо їх публічного доступу [5].

3 метою організації належної юридичної процедури отримання громадянами соціально значимої інформації, потрібної їм для здійснення своїх публічних та приватних прав, необхідно в вітчизняному законодавстві та правозастосовній практиці інкорпорувати міжнародні принципи відповідної діяльності. Першим з таких засад $є$ стимулювання відкритого уряду, яке має здійснюватися публічними органами держави. Відкритість діяльності мусить проявлятися в інформуванні громадян про їхні права і сприяння культурі відкритості уряду. Світовий досвід показує, що державна служба, яка ігнорує законодавчі приписи, може підривати навіть найбільш прогресивне законодавство. На ефективність даних вчинків безпосередньо впливають різні чинники, які зумовлюють дієвість організації державної служби. То можуть бути нормативно напрацьовані чіткі та зрозумілі, а головне, пропорційні обмеження свободи оприлюднення інформації, рівень освіченості і ступінь обізнаності суспільства в цілому.

Певні кроки у вказаному напряму в Україні здійснюються. Зокрема, прийнято документ Стратегія розвитку інформаційного суспільства в Україні. Цей акт зобов’язує органи влади забезпечити високий рівень доступності для населення інформації та технологій, вдосконалення системи державних гарантій конституційних прав у інформаційній сфері [6]. Механізм оприлюднення інформації про діяльність органів виконавчої влади визначено Законом України «Про порядок висвітлення діяльності органів державної влади та органів місцевого самоврядування в Україні засобами масової інформації» [7]. Що стосується переліку відомостей, 
обов'язкових для розміщення в інформаційних системах загального користування, зокрема в мережі Інтернет, то він визначений Постановою Кабінету Міністрів України «Про Порядок оприлюднення у мережі Інтернет інформації про діяльність органів виконавчої влади» [8]. Ця постанова встановлює обов’язок органів виконавчої влади стосовно забезпечення доступу громадян і організацій до інформації про діяльність на підставі своєчасного та регулярного розміщення інформаційних ресурсів у загальнодоступних інформаційних системах. Для практичної реалізації вказаних зобов'язань розробляється офіційний вебсайт органу державної влади та місцевого самоврядування, який містить інформацію про діяльність державного органу або органу місцевого самоврядування. Інформація про державні органи, що розміщується в мережі Інтернет, повинна містити дані про найменування органу, його структуру, адресу, відомості про повноваження, функції структурних підрозділів із зазначенням правових актів, які їх визначають, відомості про керівників державних органів та органів місцевого самоврядування, його структурних підрозділів; переліки інформаційних систем, банків даних, реєстрів, регістрів, що є у віданні державного органу, органу місцевого самоврядування, підвідомчих організацій; відомості про засновані засоби масової інформації.

Вказані акти покликані гарантувати основи відкритої інформаційної політики держави. Але, на жаль, мусимо констатувати, що вони мало сприяли демократичному поступові України у напряму досягнення прозорості влади та забезпечення вільного доступу особи до інформації. Причини тут криються, як уже вказувалося, у нормативних прогалинах щодо регулювання конкретних, а не загальних, правил поведінки та у відсутності належного правового інструментарію, який би гарантував відповідальність посадових осіб за порушення права на доступ до публічної інформації. Отже, і маємо численні приклади нехтування приписами законодавства представниками публічної влади, які залишаються практично безкарними.

Наведемо декілька типових прикладів відвертого порушення в царині реалізації права на доступ до інформації. Досить популярною є умисна підміна розпорядником інформації фактично існуючих взаємин із запитом на інформацію на інші - пов'язані із зверненням громадян. Кваліфікація надісланого особою до органу публічної влади інформаційного запиту як звернення громадянина є неправомірною. У такий спосіб робиться підміна понять 3 метою застосування неналежних засобів реагування. Відмінності у даних способах спілкування громадянина з владою наведені у роз'ясненні Міністерства юстиції України від 03 травня 2012 року. В ньому, зокрема, вказується, що право на звернення та право на доступ до публічної інформації тісно пов'язані між собою. Проте необхідно проводити розмежування термінів «звернення громадянина» та «запит на інформацію».

Право на звернення - це викладені в письмовій або усній формі пропозиції (зауваження), заява (клопотання) і скарги (ст. 3 Закону України «Про звернення громадян») до суб'єктів владних повноважень, об’єднань громадян, підприємств, установ, організацій незалежно від форм власності, засобів масової інформації. Під запитом на інформацію розуміється прохання особи до розпорядника інформації надати публічну інформацію, що знаходиться у його володінні (ст. 19 Закону України «Про доступ до публічної інформації»). Звернення стосується відстоювання прав і законних інтересів громадянина та пропозицій до діяльності суб'єктів владних повноважень, викриття їх недоліків (зауваження) в роботі, а в запитах на інформацію йдеться про надання публічної інформації, якою володіє або повинен володіти їі розпорядник. Якщо особа надіслала органу саме запит на інформацію, то він мусить виконати свої обов'язки у порядку, строк та обсяги, встановлені Законом України «Про доступ до публічної інформації».

Національне законодавство повинно здійснювати проведення громадської освіти й поширення відомостей стосовно права на доступ до інформації, визначати сферу відкритої для ознайомлення інформації і способи, якими це право може бути реалізоване. Вказані види

ISSN 2521-6473

Правова позиція, № 3 (24), 2019 
діяльності повинні здійснюватися не лише окремими публічними органами, а і спеціально створеними державними службами. В іншому разі не лише пересічні громадяни, а й професійні судді та правники часто допускають плутанину у визначеннях, яка за такого правозастосування набуває ознак свавільства. Скажімо, в ухвалі Октябрського районного суду м. Полтави від 7 березня 2017 року у справі № 554/1864/16-ц [9] правозастосовний орган відмовився порушити провадження за скаргою на бездіяльність державного виконавця, тому що вона, на думку судді, не підлягає розгляду в порядку цивільного судочинства. Таке рішення абсолютно не узгоджується із чинним законодавством України. Суть питання полягає у тому, що суддя місцевого суду всупереч закону та здоровому глузду дійшов висновку, що стягувач звернулася до виконавчої служби із інформаційним запитом. Отже, ненадання інформації у такому разі оскаржується в позовному порядку до адміністративного суду. Насправді, суддя припустився елементарної підміни понять. Порядок та підстави звернення до розпорядників інформації регулюється Законом України «Про доступ до публічної інформації».

Але за будь-якої, навіть самої бурхливої уяви не можна кваліфікувати державну виконавчу службу, котра виконує функції з примусового виконання судових рішень, як таку, що $\epsilon$ розпорядником інформації, яку вона збирає та зберігає. Як видно з матеріалів справи, позивач (стягувач) не звертався до виконавчої служби із інформаційним запитом про надання інформації, він не посилався на норми закону «Про доступ до публічної інформації». У тексті цього документу також немає запиту про надання інформації, що була отримана або створена в процесі виконання суб'єктами владних повноважень своїх обов'язків. Натомість у своєму запиті стягувач вимагає надати інформацію про хід реалізації обов'язків виконавчої служби щодо виконання судового рішення. Відмінність у даному зверненні від інформаційного запиту полягає у тому, що розпорядник публічної інформації не має обов'язку повідомляти усіх осіб без відповідного запиту. Обов'язок надати публічну інформацію упродовж п'яти днів з'являється у нього лише після отримання запиту на інформацію. Натомість державний виконавець за законом зобов'язаний повідомляти стягувача та інших учасників провадження про хід виконавчого процесу без будь-яких запитів, а невиконання такого обов'язку закон кваліфікує як правопорушення, котре зветься неправомірною бездіяльністю.

Таке правопорушення державного виконання як бездіяльність оскаржується в порядку, встановленому у Цивільному процесуальному кодексі України. Згідно із ст. 447 ЦПКУ сторони виконавчого провадження мають право звернутися до суду із скаргою, якщо вважають, що рішенням, дією або бездіяльністю державного виконавця чи іншої посадової особи органу державної виконавчої служби або приватного виконавця під час виконання судового рішення, ухваленого відповідно до цього Кодексу, порушено їх права чи свободи. Як бачимо, у цій нормі закону йдеться про оскарження протиправної бездіяльності виконавця шляхом подання скарги. Між тим, суд першої інстанції в своїй ухвалі помилково застосував норми КАСУ, які, по-перше, регулюють порядок пред'явлення позовів, а по-друге, стосуються оскарження діянь органу владних повноважень, а не конкретного виконавця. Застосування законодавства, яке регулює позовний порядок захисту права у разі, коли цивільний закон передбачає подання скарги, є неправомірним. Таке правило про подання саме скарги, а не позову, на бездіяльність державного виконавця закріплене і у ч. 4 ст. 74 Закону України «Про виконавче провадження». Отже, місцевий суд припустився порушення права особи на доступ до суду.

Висновки 3 дослідження і перспективи подальших розвідок у цьому напрямі. 3 викладеного у статті можемо дійти певних висновків. Чинне законодавство України в царині регулювання порядку доступу громадян до публічно значимої інформації потребує суттєвого розвитку та вдосконалення. Має бути розроблено механізми забезпечення коментованого конституційного права особи на рівні спеціальних підзаконних актів у всіх сферах суспіль- 


\section{Цивільне право}

ної діяльності, де інформація, що перебуває в розпорядженні публічних суб'єктів, становить суспільну важливість. Вказана діяльність повинна відбуватися за обов'язкового врахування міжнародних принципів, які знайшли усталене та виважене відтворення у відповідних актах. Разом $з$ тим є можливості вдосконалення діяльності щодо надання вільного доступу до інформації і в межах наявного правового поля. Для цього має бути змінений пріоритет прав володільців інформації на пріоритет прав та інтересів запитувачів. При цьому слід враховувати, що правила Закону України «Про доступ до публічної інформації» є мінімальними стандартами, і їх слід виконувати органами влади навіть без затвердження конкретних правил поведінки національними законами та підзаконними актами, у яких має визнаватися більш широке та змістовне право доступу до офіційних документів. Скажімо, доступ особи до публічної інформації повинен залежати винятково від наявності у неї законних підстав для цього, а не від бажання розпорядника. Саме за наявності таких підстав запитувана інформація повинна безперешкодно надаватися, а кожне порушення цього правила має тягти цивільну матеріальну відповідальність.

\section{Список використаних джерел:}

1. Цибульська А.В. Право на доступ до інформації в Україні: конституційно-правовий аспект. Вісник Дніпропетровського університету імені Альфреда Нобеля. Серія «Юридичні науки». 2013. № 2 (5). С. 49-54.

2. Рекомендації Ради Європи N R (2002)2 «Про доступ до офіційних документів» від 21.02.2002 p. URL: https://zakon2.rada.gov.ua/laws/show/994_a33.

3. Горбатюк В.В., Горбатюк С.Є. Доступ громадян до інформації: конституційно-правовий аспект. Державне управління: теорія та практика. 2012. № 2. URL: http://nbuv.gov.ua/ UJRN/Dutp_2012_2_38.

4. Чистоклетов Л.Г., Шишко В.Й. Проблеми забезпечення доступу громадян до публічної інформації від органів державної влади. Науковий вісник Львівського державного університету внутрішніх справ. 2018. № 2. С. 216-224.

5. За рік близько 200 чиновників покарано за ненадання публічної інформації. URL: https://hromadskeradio.org/programs/kyiv-donbas/za-rik-blyzko-200-chynovnykiv-pokarano-zanenadannya-publichnoyi-informaciyi.

6. Про схвалення Стратегії розвитку інформаційного суспільства в Україні: Розпорядження Кабінету Міністрів України від 15.05.2013 p. № 386-p. URL: http://zakon2.rada.gov.ua/ laws/show/386-2013-\%D1\%80.

7. Закон України «Про порядок висвітлення діяльності органів державної влади та органів місцевого самоврядування в Україні засобами масової інформації». Відомості Верховної Ради Украӥни, 1997, № 49, ст. 299.

8. Постанова Кабінету Міністрів України від 4 січня 2002 року № 3 «Про Порядок оприлюднення у мережі Інтернет інформації про діяльність органів виконавчої влади». URL: https://zakon.rada.gov.ua/laws/show/3-2002-\%D0\%BF.

9. Ухвала Октябрського районного у м. Полтаві суду від 7.03.2017 р. у справі № 554/1864/16-ц. Архів Октябрського райсуду м. Полтави за 2016 рік. 
УДК $351.74 / .76$

DOI https://doi.org/10.32836/2521-6473-2019-3-102-108

О. Ю. Дудченко, кандидат юридичних наук, асистент кафедри судоустрою та прокурорської діяльності Національного юридичного університету імені Ярослава Мудрого

\section{ПРАВООХОРОННА ФУНКЦІЯ ЯК ОДНА З ФОРМ РЕАЛІЗАЦІЇ ДЕРЖАВНОЇ ВЛАДИ}

Стаття присвячена дослідженню та класифікачії наукових підходів до визначення правоохоронної функиї, встановлення ї̈ місия серед інших функиій держави. Також у статті розглядаються наукові підходи до розуміння основних функиій, які повинна виконувати держава в рамках здійснення правоохоронної діяльності, проводиться аналогія між функиіями права загалом, здійснено характеристику окремих правоохоронних функцій.

У статті розглянуті функиї держави, встановлено, що до основних державних функиій із управління суспільством належать наступні: регулювання національних і міжнародних відносин; управління сферами економічного, сочіального, духовного життя, змінами, прочесами, розвитком, що у них відбуваються; гарантування дотримання загальнообов'язкових норм у суспільстві; забезпечення громадського порядку та начіональної безпеки; участь у світовому миробудівництві і миротворчість всередині країни.

Проаналізовані різні погляди на сутність правових форм здійснення функиій держави та їх чисельні класифікаиії. Встановлено, що функиї держави віднаходять своє конкретне втілення в певних формах їх здійснення. Найпоширенішою є дві форми здійснення функиій держави - правотворча та правозастосовна.

Також у статті досліджено наукові підходи до переліку функиій, щзо покладені на правоохоронну систему. Зазначається, щзо однією з головних рис, щзо притаманні функиіям правоохоронної системи, $\epsilon$ чітке розподілення компетенції правоохоронних органів.

Досліджено наукові підходи до систематизаиії правоохоронних функиій, встановлено, щэо всі правоохоронні функиії можна поділити на: а) головні; б) другорядні; в) допоміжні.

Встановлено, щзо різні погляди вчених щуодо правоохоронної функиії базуються на дослідженнях, щзо різняться у розумінні поняття функиіонування держави в правоохоронній сфері, а також зумовлені прогалинами у законодавстві відносно формулювання поняття правоохоронної функиіі держави. 3'ясовано, що правоохоронна функиія має системний характер та, реалізуючись в органічно пов'язаних між собою формах, здійснює реалізацію державних функиій, що втілюються у конкретні дії, формує правоохоронну діяльність.

Ключові слова: правоохоронні органи, правоохоронна система, функиії права, функиії правоохоронної системи.

\section{A. Yu. Dudchenko. Law enforcement function as one of the forms of state power realization}

The research and classification of scientific approaches to defining the law enforcement function, establishing its place among other functions of the state are considered in the scientific article. Scientific approaches to understanding the basic functions that the state must perform in the framework of law enforcement activities are also discussed, an analogy between the functions of law in general is conducted and characteristics of certain law enforcement functions are given in the article.

The functions of the state are considered in the article, it is established that the main state functions of public administration include the following: regulation of national and international relations; management of the spheres of economic, social, spiritual life, changes, processes, development that take place there; guaranteeing the observance of mandatory standards in society; ensuring public order and national security; participation in world peacebuilding and peacekeeping domestically.

(С) О. Ю. Дудченко, 2019 
Different views on the essence of legal forms of state functions and their numerical classifications are analyzed. It is established that the functions of the state find their concrete embodiment in certain forms of their implementation. Two forms of state functions - law-making and law-enforcement are the most common.

The author focuses attention that the state-legal mechanism of law enforcement function consist of an orderly set of elements that function in the law enforcement sphere of public life, in other words, the state-law mechanism forms a relatively independent social system - the law enforcement system, whose purpose is to ensure the rights and the freedoms of citizens, their implementation, law and order. Scientific approaches to the list of functions that are embedded to the law enforcement system are investigated in the article. It is noted that one of the main features that belongs to the functions of the law enforcement system is a clear distribution of competence of law enforcement bodies.

Scientific approaches to the systematization of law enforcement functions are investigated, it is established that all law enforcement functions can be divided into: a) main ones; b) minor; c) auxiliary.

It is determined that different opinions of scientists about law enforcement function are based on studies that differ in understanding the notion of state functioning in the law enforcement sphere, as well as caused by gaps in the legislation regarding the formulation of the concept of law enforcement function of the state. It is founded that the law enforcement function is systemic in nature and is implemented in organically interrelated forms and performs state functions, forms law enforcement activities, engaging in specific actions.

Key words: law enforcement bodies, law enforcement system, law functions, functions of law enforcement system.

Постановка проблеми. Завданням сучасної держави, незалежно від соціально-економічного ладу, є необхідність побудови реальних механізмів захисту прав людини. При цьому йдеться як про формально-юридичне закріплення зазначених гарантій на законодавчому рівні, так і про створення достатньої кількості державних правоохоронних відомств та недержавних організацій, котрі функціонують у сфері забезпечення, охорони й захисту прав і свобод громадянина та людини від зазіхань як з боку юридичних і фізичних осіб, так і з боку самої держави.

Для вирішення вказаного завдання на державу покладається здійснення правоохоронної функції, яка виступає однією з самостійних функцій нашої держави, що здійснюється в межах судової, законодавчої та виконавчої влади. Кожна державна функція має свій об'єкт впливу, а також свій зміст. Слід зазначити, що об'єктом є сфера суспільних відносин, на яку спрямовується державний вплив. Об'єкти слугують критеріями розмежування державних функцій. Зміст функцій держави свідчить, що держава робить, які управлінські дії в конкретній галузі вона здійснює, що саме складає зміст діяльності відповідних органів. Державно-правовий механізм здійснення правоохоронної функції складається з впорядкованої сукупності елементів, які функціонують в правоохоронній сфері суспільного життя, іншими словами державно-правовий механізм формує відносно самостійну соціальну систему - правоохоронну систему, метою діяльності якої є необхідність забезпечення додержання прав та свобод громадян, їх реалізації, правопорядку та законності.

Слід зазначити, що однією з головних умов становлення та розвитку правоохоронної системи є чітке визначення ¥іі функцій. Це зумовлено передусім тим, що саме через функції можливо розкрити сутність та соціальне призначення системи правоохорони в цілому. При цьому, незважаючи на те, що дослідженням зазначеного питання тривалий час займаються науковці різних галузей права та практики, єдина позиція щодо вказаної проблематики сьогодні відсутня.

Аналіз останніх досліджень і публікацій. Так, під час дослідження було опрацьовано низку наукових праць. Зокрема, підгрунтя для з'ясування основних понять цієї роботи склали наукові дослідження Н.І. Байтина, О.В. Бермічевої, О.Г. Варич, А.В. Гриненко, В.Г. Гриценко, О.О. Джураєвої, І.С. Дзюбка, В.І. Дяченко, Н.С. Кельмана, В.М. Кириченко, В.Н. Корельського, Ю.І. Крегул, В.В. Лазарева, К.Н. Левківського, Р.З. Лившиц, А.В. Малько, І.С. Марочкіна, М.І. Матузової, Л.А. Морозової, В.Д. Перевалова, Г.І. Петрова, І.С. Самощенко, Н.В. Сібільо- 
вої, О.Ф. Скакуна, В.Н. Хропанюка, О.І. Ющика, а також інших поважних вчених. У статті були враховані висновки наведених вчених. Однак відсутність єдиної точки зору стосовно переліку та класифікацій правоохоронних функцій залишає простір для подальших досліджень.

Мета статті - дослідити та класифікувати наукові підходи до визначення правоохоронної функції, встановити іiї місце серед інших функцій держави.

Виклад основного матеріалу. Однією з головних рис, що належить функціям правоохоронної системи, є чітке розподілення компетенції правоохоронних органів. Наявність або відсутність функції правоохоронної діяльності допускає визначення відповідного правоохоронного органу. Таким чином, наявність функції зумовлює також наявність правоохоронного органу. Інакше кажучи, немає функції - немає і правоохоронного органу. Функції правоохоронної системи є взаємопов'язаними та такими, що доповнюють одна одну.

Так, науковці надають таке визначення функціям правоохоронної системи: основні напрями діяльності відповідних органів, що зумовлені їх загально соціальним призначенням і конкретизовані в компетенції і повноваженнях [25]. А.В. Гриненко під функціями правоохоронної системи розуміє основні напрями діяльності органів, які витікають 3 їх загального соціального призначення і конкретизуються у відповідних правах і обов’язках [8, с. 10]. В зазначеному тлумаченні необхідно зробити наголос на тому, діяльність яких саме органів мається на увазі, оскільки, на наш погляд, має йтися лише про органи, що входять до правоохоронної системи.

Охорона та регулювання суспільних відносин - саме це і $є$ основним покликанням права. Охоронна функція права зумовлена соціальним призначенням напряму правового впливу, націленого на охорону загальнозначущих, найголовніших суспільних відносин, їх недоторканість [15, с. 51]. Охоронна діяльність держави спрямовується на охорону самого права, оскільки від цього напряму залежить ефективність його функціонування, а охоронна функція права сприяє охороні наявних суспільних відносин. Таким чином, право охороняє відносини, які виникають в суспільстві, та тим самим утворює юридичне підгрунтя для діяльності правоохоронних органів і функціонування правоохоронної системи взагалі.

Необхідно погодитись із політологами К.М. Левківським та І.С. Дзюбком стосовно того, що зміст функцій пізнає найбільших змін саме під час перехідних етапів та періодів радикальних змін. Зазначені автори здійснюють класифікацію функції держави за такими критеріями: принципи поділу влади на виконавчу, законодавчу, судову; сторони дії держави - зовнішні та внутрішні; сфери державного впливу - соціальна, економічна, духовна, культурна, правова; регулювання процесів - самоорганізація, саморегулювання, самодіяльність, самоуправління тощо; загальнополітичні підходи - загальносоціальна діяльність, забезпечення народовладдя; обсяг впливу - підтримання світового порядку, національні; масштабність значення - неосновні та основні, першочергові та другорядні. До основних державних функцій із управління суспільством належать такі: регулювання національних і міжнародних відносин; управління сферами економічного, соціального, духовного життя, змінами, розвитком, процесами, що у них відбуваються; гарантування дотримання загальнообов'язкових норм в суспільстві; забезпечення громадського порядку та національної безпеки; участь у світовому миробудівництві і миротворчість всередині країни [24, с. 273-274]. Вважаємо, що на підставі цього переліку із високим ступенем об'єктивності можна скласти уявлення стосовно функцій держави.

Функції держави віднаходять своє конкретне втілення в певних формах їх здійснення. Так, під правовими формами реалізації функцій держави розуміють однорідну за своїми зовнішніми ознаками (юридичним наслідкам і характеру) діяльність органів держави щодо керівництва суспільством шляхом видання нормативних актів [6, с. 151]. Узагальнення концептуальних підходів стосовно даної проблематики дозволяє дійти висновку, що під право- 
вими формами здійснення державних функцій розуміють однорідну за зовнішніми ознаками (юридичними наслідками і характером) діяльність державних органів [26, с. 51-57], пов'язану 3 прийняттям (виданням) правових (юридичних) актів [23, с. 12-14] і яка тягне за собою юридичні (правові) наслідки [10, с. 108-109].

У теоретичних джерелах $є$ різні погляди на сутність правових форм здійснення функцій держави та, відповідно, чисельні класифікації останніх. На думку деяких дослідників, до них належать: а) правотворча діяльність - форма здійснення функцій держави шляхом підготовки та прийняття, а також санкціонування нормативних актів [31, с. 152], їх зміни або відміни діючих норм права [3, с. 229], а також конкретних актів (застосування норм права) $[16$, с. 72] та інших джерел права [17, с. 58]; б) правовиконавча [1, с. 46], управлінсько-виконавча, оперативно-виконавча чи правозастосовна діяльність - форма реалізації державних функцій шляхом діяльності державних органів щодо виконання законів та підзаконних актів шляхом прийняття актів застосування права та видання обов'язкових до виконання індивідуально-правових рішень [19, с. 76]. Ця діяльність пов'язана із повсякденним вирішенням різносторонніх питань у вигляді видання актів застосування права, котрі $\epsilon$ підставою виникнення, зміни та припинення правовідносин [18, с. 49]. За допомогою цієї форми здійснюється реалізація відносин між громадянами, громадськими організаціями і органами держави, їх взаємні обов'язки і права в політичній, економічній, культурній, соціальній та інших галузях суспільного життя. Саме від діяльності правовиконавчої залежить факт, чи будуть реалізовані закони й інші нормативні акти або вони залишаться лише бажаннями законодавців. Це повсякденна робота щодо розв'язання багатоманітних питань управлінського характеру, для здійснення якої виконавчо-розпорядчі органи приймають відповідні акти [4, с. 177-178].

На думку А.В. Малька, М.I. Матузова [29, с. 76] та інших авторів, існують дві форми здійснення функцій держави - правотворча та правозастосовна. Правозастосовна діяльність своєю чергою поділяється на правоохоронну і оперативно-виконавчу. Зазначена позиція здається такою, що недооцінює значення правоохорони в реалізації функцій держави. Так, правоохорона за своїм змістом значно ширше ніж правозастосування, оскільки існування правових приписів, що закріплюють відповідальність за порушення закону, слугує підтриманню правопорядку та законності в державі навіть за умов, коли не виникає необхідності в безпосередньому застосуванні передбачених законом заходів відповідальності. Це пояснюється впливом, який здійснює право на свідомість суспільства, формуючи у одних громадян острах зазнати позбавлення своїх благ, передбачених у санкції правової норми, а в інших членів суспільства виховує повагу до закону і прагнення неухильно додержуватися встановлених правових приписів. Необхідно наголосити, що українська держава як публічна інституція здійснює охоронну функцію через правоохоронну діяльність, що $\epsilon$ важливим фактором під час формування суспільної моралі, соціальних уявлень стосовно ефективності та дієвості конституційного ладу. Також слід зазначити, що існують деякі види правоохоронної діяльності, які недостатньою мірою регламентуються правовими приписами. Так, діяльність щодо профілактики правопорушень та злочинів врегульована правом на самому поверхневому рівні, на рівні напрямів діяльності та принципів. Безпосереднє ж ії здійснення лишається на вільний розсуд виконавців, котрі самостійно вирішують, що може бути доцільнішим у певній ситуації - співпрацювати із виробничими колективами і навчальними закладами, залучити засоби масової інформації тощо. Отже, вказані дії, які є правоохоронними за своєю природою, не можуть бути зведені винятково до правозастосовчих форм діяльності.

Сьогодні єдиного підходу до визначення терміну «правоохоронної функції» не сформовано ані в юридичній літературі, ані в чинному законодавстві. Багатоелементність та складність правоохоронної функції держави $є$ підставою існування чисельних точок зору сто-

ISSN 2521-6473

Правова позиція, № 3 (24), 2019 
совно її сутності, поняття та навіть назви. Л.А. Морозова розглядає функцію охорони свобод і прав громадян, забезпечення правопорядку та законності як внутрішню функцію держави [20, с. 51-59], О.Д. Тихомиров, В.П. Пастухов, С.Л. Лисенков, А.М. Колодій та В.В. Копєйчиков відмічають окремі функції захисту законності, правопорядку, охорони свобод і прав людини, які виступають як основні державі функції [12, с. 73], В.Н. Хропанюк - як функцію охорони правопорядку [34, с. 159]. В.В. Лазарєв виокремлює охорону прав власності та охорону правового порядку, інших свобод і прав громадян [33, с. 285], М.С. Кельман - як охорону свобод і прав громадян, забезпечення правопорядку та законності [13, с. 71], В.М. Корельський і В.Д. Перевалов - як охорону правопорядку і охорону наявних форм власності [32, с. 146]. О.Ф. Скакун [27, с. 52], О.І. Ющик [35, с. 21-22], В.М. Кириченко [14, с. 83] вважають, що правоохоронна функція виступає окремою функцією держави. І.С. Марочкін та Н.В. Сібільова розглядають правоохоронну функцію у вигляді складового елементу діяльності державних органів та інших органів, установ і організацій, їх посадових осіб, що спричинено конституційними вимогами дотримання охорони правопорядку, законності, свобод та прав громадян та інтересів суспільства в цілому. Вчені наголошують, що вказана діяльність для більшості організацій та органів є за своєю природою вторинною, а не основною та полягає здебільшого в забезпеченні виконання їх організаційно-управлінських функцій в галузі економіки, фінансів, науки, освіти тощо [21, с. 63].

У зв’язку з багатоманітністю правоохоронних функцій варто провести їх систематизацію. В.І. Дяченко пропонує всі правоохоронні функції поділити на: а) головні; б) другорядні; в) допоміжні. Так, до головних правоохоронних функцій В.І. Дяченко пропонує відносити такі, що безпосередньо пов'язані з протидією злочинності та правопорушенням, тими, що тягнуть за собою юридичну відповідальність у сфері публічного права. Стосовно допоміжних правоохоронних функцій, то В.І. Дяченко пропонує відносити до них такі функції: а) контрольна (наглядова); б) дозвільна (надання дозволів на проведення відповідної діяльності, зокрема підприємницької, чи вчинення певних дій); в) правороз'яснювальна (яка включає в себе функцію надання правової допомоги); г) аналітична та методична; г) інформаційна (здійснення інформування інших державних органів, у тому числі правоохоронних); д) нормотворча (з правом прийняття актів міжвідомчого характеру); е) координаційна [11, с. 11].

В.Г. Гриценко пропонує наступний перелік функцій правоохоронної системи. Головними на його думку є захисна (правоохоронна), профілактична, оперативно-розшукова, виконавча, розслідування злочинів, адміністративна. До допоміжних він відносить організаційно-управлінську функцію, координаційну функцію, контрольну, інформаційно-аналітичну [9, с. 134]. До головних належать ті функції, що безпосередньо пов'язані із боротьбою зі злочинністю та правопорушеннями і передбачають юридичну відповідальність. Правоохоронна (захисна) функція має на меті охорону держави від зовнішніх загроз для національної безпеки України, охорону внутрішнього ринку, збереження миру та міжнародної безпеки, забезпечення екологічної безпеки, суспільного правопорядку, захист інтересів споживачів, створення відповідних умов для підтримання законності [7, с. 26]. Правоохоронна функція також полягає у здійсненні на договірних засадах охорони майна фізичних юридичних та фізичних осіб усіх видів власності. Профілактична функція розкривається в комплексі мір, що спрямовуються на запобігання злочинам й іншим правопорушенням, виявлення і усунення умов та причин, що їм сприяють [21, с. 103]. Виконавча функція полягає у здійсненні у рамках своїх повноважень адміністративних стягнень [21, с. 104]. Адміністративна функція спрямована на виконавчо-розпорядницьку роботу правоохоронних органів з організації та здійснення охорони громадського правопорядку і сприяння забезпеченню громадської безпеки в межах повноважень, встановлених законом [22]. 
Допоміжні функції правоохоронної системи - це конкретна діяльність, змістом якої $\epsilon$ допомога ефективному здійсненню вищеназваних головних функцій. Організаційно-управлінська функція у структурі правоохоронної системи має відомчий характер. Вона спрямовується кожному правоохоронному органу залежно від його підвідомчої належності [28, с. 45]. Координація правоохоронної діяльності - це є управлінська функція, що спрямована на систематизацію і об'єднання зусиль для досягнення соціально-бажаних загальних цілей. Координація взаємодії правоохоронних органів виступає одним із головних чинників, що спрямований на об’ єднання зусиль правоохоронних органів в протидії правопорушенням [30, с. 301]. Основною метою інформаційно-аналітичної функції можна назвати науково-обгрунтовану підтримку процесів підготовки, прийняття та втілення в життя управлінських рішень і задоволення інформаційних потреб суспільства. Контрольна функція правоохоронної системи - це такий напрям та вид діяльності правоохоронних органів, який полягає в забезпеченні чіткої діяльності державного механізму за додержанням норм права.

Висновки 3 дослідження і перспективи подальших розвідок у цьому напрямі. Отже, з огляду на викладене вище можна констатувати, що різні погляди вчених щодо правоохоронної функції базуються на дослідженнях, що різняться у розумінні поняття функціонування держави в правоохоронній сфері, а також зумовлені прогалинами у законодавстві відносно формулювання поняття правоохоронної функції держави. На нашу думку, правоохоронна функція має системний характер та, реалізуючись в органічно пов'язаних між собою формах, здійснює реалізацію державних функцій, що втілюються у конкретних діях, які й формують правоохоронну діяльність.

\section{Список використаних джерел:}

1. Алексеев С.С. Теория государства и права. Москва : Юридическая литература, 1985. $410 \mathrm{c}$.

2. Байтин М.И. Сущность и основные функции социалистического государства. Саратов : Саратовск. ун-т, 1979. 302 с.

3. Байтин М.И. Сущность права (Современное нормативное правопонимание на грани двух веков) : монография. Москва : ООО ИД «Право и государство», 2005. 544 с.

4. Бермічева О.В. Соціальна функція в Україні : дис. ... кандидата юрид. наук : 12.00 .01 / Нац. ун-т внутр. справа. Харків, 2002. 174 с.

5. Бобир В.І. Правознавство : навчальний посібник. Київ : Юріформінтер, 1998. 289 с.

6. Варич О.Г. Економічні функції сучасної держави: природа, сутність, зміст, тенденції розвитку в Україні : дис. ... кандидата юрид. наук : 12.00.01 / Київ, 2006. 206 с.

7. Горелишев С.А., Бобков Ю.П., Побережний А.А. Структура та функції перспективної інформаційно-аналітичної системи внутрішніх військ. Зб. наук. пр. Акад. внутр. військ МВС України. 2012. № 1. С. 26-30.

8. Гриненко А.В. Судоустройство и правоохранительные органы в вопросах и ответах : научное пособие. Москва : Проспект, 2014. 232 с.

9. Гриценко В.Г. Функції правоохоронної системи України. Публічне право. 2015. № 1. С. 132-137.

10. Джураєва О.О. Функції сучасної держави : дис. ... кандидата юрид. наук : 12.00 .01 / Одеськ. нац. юрид. академія. Одеса, 2006. 190 с.

11. Дяченко В.І. Система правоохоронних органів : навч. посіб. Київ : КНЕУ, 2003. 320 с.

12. Загальна теорія держави та права / А.М. Колодій та ін.; за заг. ред. В.В. Копєйчикова. Київ : Юрінком Інтер, 2001. 320 с.

13. Кельман М.С. Теорія держави : навч. посібник. Тернопіль : Поліграфіст, 1997. 330 с. 
14. Кириченко В.М. Правознавство : модульний курс. Київ : Центр учбової літератури, 2007. $328 \mathrm{c}$.

15. Крегул Ю.І. Адміністративне право і процес : навч. посіб. Київ : КНЕУ, 2012. 223 с.

16. Лазарев В.В. Общая теория права и государства. Москва : Юрист, 1994. 359 с.

17. Лившиц Р.3. Современная теория права : краткие очерки. Москва : ИГПАН, 1992. 64 с.

18. Малько А.В., Нырков В.В., Шундиков К.В. Теория государства и права: Элементарный курс. Москва : Проспект, 2007. 384 с.

19. Малько О.В. Теория государства и права в вопросах и ответах. Москва : Юристь, 1997. $197 \mathrm{c}$.

20. Морозова Л.А. Функции государства на современном этапе. Государство и право. 1993. № 7. C. 51-59.

21. Організація судових та правоохоронних органів : підручник для студентів юрид. спеціальностей вищих навч. закладів. / І.С. Марочкін, Н.В. Сібільова, В.П. Тихий та ін. За ред. І.Є. Марочкіна, Н.В. Сібільової. Харків : ТОВ «Одіссей», 2007. 528 с.

22. Основні напрями діяльності правоохоронних органів щодо забезпечення економічної безпеки. URL: http://pidruchniki.com/12590605/ekonomika/osnovni_napryami_diyalnosti_ pravoohoronnih_organiv_schodo_zabezpechennya_ekonomichnoyi_bezpeki

23. Петров Г.И. Сущность советского административного права. Изд-во Ленинградск. ун-та, 1959. $184 \mathrm{c}$.

24. Політологія / за заг. ред. І.С. Дзюбка, К.М. Левківського. Київ : Думка, 1998. 347 с.

25. Правоохранительные органы. URL: http://mehanikabiz.narod.ru/index/0-8.

26. Самощенко И.С. Общая теория советского права. Москва : Знание, 1980. 240 с.

27. Скакун О.Ф. Теория государства и права : учебник. Харьков : Консум, 2000. 704 с.

28. Суд, правоохоронні та правозахисні органи України : навч. посіб. / В.С. Ковальський, В.Т. Білоус, С.Е. Демський та ін. ; Відп. ред.. Я. Кондратьєв. Київ : Юрінком Інтер, 2002. 320 с.

29. Теория государства и права : курс лекций. / М.И. Байтин и др.; под. ред. М.И. Матузова, А.В. Малько. Москва : Юристь, 1997. 677 с.

30. Теория государства и права : учеб. для юрид вузов и ф-тов. / под ред. В.М. Корельского, В.Д. Перевалова. 2-е изд., изм. и доп. Москва : НОРМА. 2002. 616 с.

31. Теория государства и права : учебник / под ред. В.М. Корельского, В.Д. Перевалова. Москва : Издат. группа Инфра-Норма, 1997. 376 с.

32. Теория государства и права : учебник / под ред. В.М. Корельского и В.Д. Перевалова. Москва : Юристь, 1999. 456 с.

33. Теория государства и права : учебник / под ред. В.В. Лазарева. Москва : Юридическая литература, 1996. 448 с.

34. Хропанюк В.Н. Теория государства и права : учеб. пособ. / под ред. В.Г. Стрекозова. Москва : Дабахов, Ткачев, Димов, 1995. 384 с.

35. Ющик О.I. Правова реформа: загальне поняття, проблеми здійснення в Україні. Київ : Дія, 1997. 234 с. 
УДК 343.2/.7

DOI https://doi.org/10.32836/2521-6473-2019-3-109-118

\author{
B. О. Поповичук, кандидат юридичних наук, \\ старший слідчий з особливо важливих справ \\ Головного слідчого управління \\ фрінансових розслідувань \\ Державної фіскальної служби України
}

\title{
ВДОСКОНАЛЕННЯ ЗАКОНОДАВСТВА УКРАЇНИ ПРО КРИМІНАЛЬНУ ВІДПОВІДАЛЬНІСТЬ ЗА НЕЗАКОННЕ ВИКОРИСТАННЯ СИМВОЛІКИ ЧЕРВОНОГО ХРЕСТА, ЧЕРВОНОГО ПІВМІСЯЦЯ, ЧЕРВОНОГО КРИСТАЛА
}

У статті надані пропозиції та рекомендації, спрямовані на вдосконалення законодавства України про кримінальну відповідальність за незаконне використання символіки Червоного Хреста, Червоного Півмісяия, Червоного Кристала, у тому числі обтрунтовано доцільність виключення ст. $435 \mathrm{KK}$ України та доповнення ст. 445 КК України відповідними частинами.

Крім того, обтрунтовано доиільність доповнення Кримінального кодексу Украӥни статтею 445-1 «Незаконне ввезення товарів, під виглядом гуманітарної допомоги на тимчасово не підконтрольну органам державної влади територію України, на яких відсутня символіка Червоного Хреста, Червоного Півмісяия, Червоного Кристала, та їх використання».

У зв'язку з тим, щзо диспозииія вищевказаних статей Кримінального Кодексу Украӥни має бланкетний характер, обтрунтовано доиільність внесення змін та доповнення до: cm. 9 Закону Украӥни «Про Товариство Червоного Хреста Украӥни»; ст. 3 Статуту Товариства Червоного Хреста України; cm. cm. 5, 9, 12 Закону Украӥни «Про гуманітарну допомогу»; ст. 15 Закону Украӥни «Про символіку Червоного Хреста, Червоного Півмісяия, Червоного Кристала в Украӥні», а також до ст. 963 Кримінального кодексу України; ст. 214 Кримінального процесуального кодексу Украӥни.

Гострим і актуальним постає на сьогодні питання вдосконалення законодавства у сфері кримінально-правової відповідальності за незаконне використання символіки Червоного Хреста, Червоного Півмісяия, Червоного Кристала в умовах збройного конфлікту та на тимчасово окупованій території України.

Сучасний стан інституту відповідальності за злочини проти миру, безпеки людства та міжнародного правопорядку підлягає конвенціональній регламентаиії, основу якої становить принии визнання пріоритетності й суспільної небезпеки наслідків скоєння злочинів проти миру, безпеки людства та міжнародного правопорядку,

Ключові слова: злочини проти миру та безпеки людства та міжнародного правопорядку, кримінальна відповідальність, вдосконалення законодавства; незаконне використання символіки Червоного Хреста, Червоного Півмісяия, Червоного Кристала; виключення ст. 435 КК Украӥни; доповнення статті 445-1 КК України.

V. O. Popovichuk. Senior investigator on especially important cases chief financial investigator investigations of the state fiscal service of Ukraine

The article provides suggestions and recommendations aimed at improving the legislation of Ukraine on criminal liability for the illegal use of the symbols of the Red Cross, Red Crescent, Red Crystal, including the substantiation of the expediency of the exclusion of Art. 435 of the Criminal Code of Ukraine and amendments to Art. 445 of the Criminal Code of Ukraine by the relevant parts.

In addition, the expediency of supplementing the Criminal Code of Ukraine with Article 445-1 "Illegal import of goods, under the guise of humanitarian assistance for temporarily not controlled by state authorities in the territory of Ukraine, which do not have the symbols of the Red Cross, Red Crescent, Red Crystal, and their use", was substantiated.

(C) В. О. Поповичук, 2019

ISSN 2521-6473

Правова позиція, № 3 (24), 2019 
Due to the fact that the disposition of the aforementioned articles of the Criminal Code of Ukraine is blanket, the expediency of introducing amendments and additions to: art. 9 of the Law of Ukraine "On the Society of the Red Cross of Ukraine"; Art. 3 of the Charter of the Red Cross Society of Ukraine; Art. Art. 5, 9, 12 of the Law of Ukraine "On Humanitarian Aid"; Art. 15 of the Law of Ukraine "On the Symbolism of the Red Cross, Red Crescent, Red Crystal in Ukraine", as well as to Art. 963 of the Criminal Code of Ukraine; Art. 214 of the Criminal Procedural Code of Ukraine.

The issue of improving the legislation in the field of criminal liability for the illegal use of the symbols of the Red Cross, Red Crescent, Red Crystal in the conditions of an armed conflict and in the temporarily occupied territory of Ukraine today is a pressing and urgent issue.

The current state of the institute of responsibility for crimes against peace, human security and international law is subject to conventional regulation, which is based on the principles of recognizing the priority and public danger of the consequences of crimes against peace, human security and international law and order.

States are required to provide in domestic law for measures aimed at preventing and stopping all cases of illegal use of the symbolism of the Red Cross, Red Crescent, Red Crystal, both in peacetime and in situations of armed conflict.

Key words: crimes against the peace and security of mankind and international rule of law, criminal liability, improvement of legislation; illegal use of the symbol of the Red Cross, Red Crescent, Red Crystal; exclusion of art. 435 of the Criminal Code of Ukraine; addition to article 445-1 of the Criminal Code of Ukraine.

Постановка проблеми. Проблематика кваліфікації та правозастосування злочинів, передбачених ст. ст. 435, 445 КК України, складається із недосконалого кримінального законодавства України, яке регулює порядок використання символіки Червоного Хреста, Червоного Півмісяця, Червоного Кристала, у тому числі в розмитості та неконкретизованості їх викладення в Кримінальному Кодексі України.

Аналіз останніх досліджень і публікацій. Питання застосування міжнародно-правових та міжнародно-кримінальних норм у світлі підтримки міжнародного правопорядку досліджували такі науковці, як П.С. Берзін, В.Г. Буткевич, М.В. Буроменський, Ю.А. Дорохіна, В.І. Євінтов, Г.В. Ігнатенко В.І. Кузнецов та ін. [6, с. 711]

Аналізуючи праці цих науковців, варто зазначити, що питання, пов'язані з використанням символіки Червоного Хреста, Червоного Півмісяця, Червоного Кристала, розкрито неповно. Так, більшість особливостей кримінальної відповідальності за незаконне використання символіки Червоного Хреста, Червоного Півмісяця, Червоного Кристала залишилися поза увагою науковців у галузі кримінального права.

Метою статті $\epsilon$ визначення проблем та надання пропозицій щодо вдосконалення законодавства України про кримінальну відповідальність за незаконне використання символіки Червоного Хреста, Червоного Півмісяця, Червоного Кристала.

Виклад основного матеріалу дослідження. Гострим і актуальним постає на сьогодні питання вдосконалення законодавства про кримінальну відповідальність за незаконне використання символіки Червоного Хреста, Червоного Півмісяця, Червоного Кристала в умовах збройного конфлікту, режиму проведення операції об'єднаних сил та правового режиму тимчасово окупованих територій України.

Вказана символіка виконує важливі функції захисту цивільного мирного населення, має належний специфічний режим використання та користується міжнародно-правовим захистом, а тому її незаконне використання як у мирний, так і воєнний час є недопустимим.

Статистичні спостереження соціальних мереж, інформаційних сайтів, наявність на вулицях міст України та в громадському транспорті вивісок, реклам із символікою Червоного Хреста, Червоного Півмісяця та Червоного Кристала дають можливість стверджувати про неодноразове систематичне незаконне використання символіки Червоного Хреста, Червоного Півмісяця та Червоного Кристала. 
3 метою ефективної боротьби із цими фактами необхідно вдосконалювати законодавство України, яке регулює порядок використання символіки Червоного Хреста, Червоного Півмісяця, Червоного Кристала та контроль за використанням цієї символіки.

Основна проблематика відсутності правового застосування статей 435, 445 КК України в розмитості та неконкретизованості їх викладення в Кримінальному Кодексі України.

Так, безпосереднім об’єктом злочину є міжнародний правопорядок у сфері використання символіки Червоного Хреста, Червоного Півмісяця, Червоного Кристала. На цей об'єкт здійснюється однакове посягання як за незаконного використання символіки Червоного Хреста, Червоного Півмісяця, Червоного Кристала, так і при використанні символіки, яка імітує використання цієї символіки (використання подібних кольорів, зображень, слів).

Однак використання іншої символіки, що імітує використання символіки Червоного Хреста, Червоного Півмісяця, Червоного Кристала, свого відображення в Кримінальному Кодексі України як кримінальне правопорушення не знайшло.

У судовій практиці України неодноразово були встановлені випадки, коли особи з корисливих мотивів представлялись співробітниками Червоного хреста 3 метою заволодіння грошовими коштами та майном громадян, використовуючи авторитет Міжнародного руху Червоного Хреста та Червоного Півмісяця. В цьому випадку особи, представляючись співробітниками Червоного Хреста, фактично символізували в усному вигляді своє, нібито, відношення до цього руху, і ця смислова інформація була сприйнята адресатами (громадянами), які мають довіру та повагу до авторитету Міжнародного руху Червоного Хреста та Червоного Півмісяця, у зв'язку із чим кримінальні правопорушники за симулювання наявності відповідного статусу отримували відповідні безпідставні преференції як матеріального (грошові кошти, майно), так і не матеріального характеру (можливість безпідставного отримання відповідних благ, соціального пакету), тим самим незаконно використовували один з елементів символіки Червоного Хреста, його назву (слово).

Відповідно до принципів, визначених Міжнародним рухом Червоного Хреста та Червоного Півмісяця, закріплених у міжнародних договорах, ратифікованих Україною, дії, спрямовані на симулювання володіння відповідним статусом, щоб викликати довіру, з метою отримання безпідставних преференцій, а також дії, направлені на підрив авторитету Міжнародного червонохресного руху, є забороненими.

Ці кримінальні правопорушення посягають на встановлений порядок у сфері використання символіки Червоного Хреста, Червоного Півмісяця і Червоного Кристала. Однак ці факти свого відображення в Кримінальному Кодексі України як кримінальне правопорушення не знайшли.

Також потрібно мати на увазі, що метою незаконного використання символіки Червоного Хреста, Червоного Півмісяця і Червоного Кристала може бути умисне ухилення від сплати податків, митних платежів тощо, оскільки товари під символікою Червоного Хреста, Червоного Півмісяця і Червоного Кристала звільняються від сплати податків, обов'язкових платежів. Цей факт також може бути мотивом для вчинення злочину, передбаченого ст. 445 КК України.

Так, згідно із ч. 4 ст. 287 Митного кодексу України [1] «Особливості оподаткування митом деяких товарів», товари, що ввозяться на митну територію України на адресу Товариства Червоного Хреста України, його органів та місцевих організацій відповідно до Закону України «Про Товариство Червоного Хреста України» як гуманітарна чи доброчинна допомога, звільняються від оподаткування ввізним митом.

Згідно зі ст. 18 Закону України «Про Товариство Червоного Хреста України» [2] товари та матеріальні цінності, які надходять у тому числі з-за кордону Товариству, його органам 
та місцевим організаціям як гуманітарна чи доброчинна допомога, тобто без мети одержання прибутку, розподіляються і використовуються Товариством, його органами та місцевими організаціями винятково безоплатно для виконання статутних завдань Товариства. Такі товари та матеріальні цінності звільняються відповідно до закону від оподаткування, у тому числі митом, та плати за виконання митних формальностей поза місцем розташування митних органів або поза робочим часом, встановленим для органів доходів і зборів.

Таким чином, товари, які ввозяться на територію України із символікою Червоного Хреста, звільняються від сплати ввізного мита, здійснюється їх ввіз за спрощеною системою без сплати митних формальностей поза місцем розташування митних органів.

Згідно зі ст. 18 Закону України «Про Товариство Червоного Хреста України» [2] Товариство, його місцеві організації, створені (засновані) ними підприємства звільняються від сплати податків та інших платежів згідно із законодавством.

Так, відповідно до пп. 165.1.4 п. 165.1 ст. 165 Податкового кодексу України [3], доходи, які не включаються до розрахунку загального місячного (річного) оподатковуваного доходу, сума виплат чи відшкодувань (крім заробітної плати чи інших виплат та відшкодувань за цивільно-правовими договорами), що здійснюється Товариством Червоного Хреста України на користь отримувачів благодійної допомоги відповідно до законодавства України з урахуванням п. 170.7 ст. 170 цього Кодексу. Згідно $з$ пп. 170.7.1 п. 170.7 ст. 170 Податкового кодексу України «Оподаткування благодійної допомоги» не оподатковується та не включається до загального місячного або річного оподатковуваного доходу платника податку благодійна, у тому числі гуманітарна допомога (далі - благодійна допомога), яка надходить на його користь у вигляді коштів або майна (безоплатно виконаної роботи, наданої послуги) та відповідає вимогам, визначеним цим пунктом. Згідно з пп. 170.7.4 п. 170.7 ст. 170 Податкового кодексу України, не включається до оподатковуваного доходу цільова благодійна допомога, що надається резидентами - юридичними чи фізичними особами у будь-якій сумі (вартості) державному або комунальному закладу чи благодійній організації, у тому числі Товариству Червоного Хреста України, що надають послуги особам, які не мають житла, з харчування та облаштування на нічліг [3].

Таким чином, один із способів умисного ухилення від сплати податків, митних платежів та інших обов'язкових надходжень $є$ незаконне та безпідставне використання символіки Червоного Хреста на товарах чи на фінансово-господарських документах на даний товар. В такому випадку буде ідеальна сукупність злочинів, передбачена статтями 212 та 445 Кримінального Кодексу України.

Товариство Червоного Хреста України є всеукраїнською добровільною громадською гуманітарною організацією. Товариство допомагає державі в наданні медичної й гуманітарної допомоги під час збройних конфліктів і в мирний час, бере участь у наданні міжнародної допомоги у разі катастроф та надзвичайних ситуацій, забезпечує медико-соціальну допомогу найменш соціально захищеним верствам населення.

Так, на теперішній час залишається законодавчо не врегульованим питання надання гуманітарної допомоги населенню на тимчасово окупованій території України. У ході вивчення статистичних спостережень соціальних мереж, інформаційних сайтів, засобів масової інформації встановлено систематичну закономірність посилення бойових дій на межі розмежування після направлення гуманітарних конвоїв Російською Федерацією на тимчасово окуповану територію України.

Одним з основних напрямів міжнародного червонохресного руху є надання гуманітарної допомоги під час збройних конфліктів та в мирний час найменш соціально захищеним верствам населення. 
Таким чином, на тимчасово окупованій території України надання гуманітарної допомоги населенню повинно здійснюватись тільки через Товариство Червоного Хреста України або представників міжнародного червонохресного руху.

Контроль за використанням символіки Червоного Хреста насамперед повинен здійснюватися Національним товариством Червоного Хреста, також необхідно закріпити на законодавчому рівні як обов'язок, а не право. Тобто необхідним видається внесення змін до Закону України «Про Товариство Червоного Хреста України» та до Статуту Товариства Червоного Хреста України.

Виходячи 3 того, що ст. 445 КК України передбачено відповідальність за таке неправомірне використання символіки Червоного Хреста, Червоного Кристала та Червоного Півмісяця, як: заборона використання зображення емблем Червоного Хреста, Червоного Півмісяця та Червоного Кристала на знаках для товарів і послуг, промислових зразках; використання цих слів або зображень як елемента знака для товарів і послуг, промислових зразків чи найменувань згідно з чинним законодавством України тощо, - очевидним $\epsilon$ те, що ці дії може здійснити суб'єкт господарювання, який одночасно є або фізичною особою - підприємцем, або юридичною особою.

За дії, вчинені від імені юридичних осіб, відповідають конкретні фізичні особи. Відповідно до ст. $96^{3}$ КК України, до юридичних осіб може бути застосовано заходи кримінального-правового характеру: штраф; конфіскація майна; ліквідація.

Недоліком кримінального законодавства України є відсутність у ст. $96^{3}$ КК України вказівки на злочин, що передбачений ст. ст. $445,445^{1}$ КК України як підстави для застосування до юридичної особи заходів кримінально-правового характеру.

На думку О.О. Бахуринської, ст. 445 КК України не застосовується, якщо дії можна кваліфікувати за статтями, що передбачають спеціальні норми, зокрема, як військовий злочин за ст. 435 КК України, або як порушення законів і звичаїв війни за ст. 438 КК України. У ст. 435 КК України в основі виділення спеціальної норми є поєднання ознак спеціального суб'єкта, яким визнається військовослужбовець, з ознаками місця або обстановки вчинення злочину - в районі воєнних дій або в умовах воєнного стану. Під ст. 438 КК підпадають ті види незаконного використання зазначеної символіки, які характеризуються вищим ступенем суспільної небезпечності злочинних діянь та тяжкості спричинених ними наслідків [4, с. 624].

На підставі вищевикладеного можна стверджувати, що діяння, пов'язані із незаконним використанням символіки Червоного Хреста, Червоного Півмісяця, Червоного Кристала у їх відповідних різновидах, можна кваліфікувати за однією з трьох статей КК України, а саме: або ст. 435 КК, або ст. 438 КК, або ст. 445 КК.

Цей факт ускладнює проблематику конкуренції кримінально-правових норм та правильної кваліфікації злочину, пов'язаного з незаконним використанням символіки Червоного Хреста, Червоного Півмісяця, Червоного Кристала. Виходячи 3 того, що назви злочинів тих видів, що передбачені статтями 435, 445 КК, є майже тотожними, виникає значна ймовірність помилкової кваліфікації, пов'язаної із застосуванням норми кримінального законодавства. 3 урахуванням цього цілком можливим видається об'єднання цих норм в одну.

Отже, пропонуємо внести такі зміни до КК України:

I. Викласти ст. 445 Кримінального кодексу України в такій редакції:

«Незаконне використання символіки Червоного Хреста, Червоного Півмісяця, Червоного Кристала»

1. Незаконне використання символіки Червоного Хреста, Червоного Півмісяця, Червоного Кристала в засобах масової інформації, в інтернеті, на вивісках, плакатах, оголошеннях, листівках, документах тощо або використання будь-якої іншої символіки, яка їх імітує (використання подібних кольорів, зображень, найменувань, слів, що можуть призвести до змішу-

ISSN 2521-6473

Правова позиція, № 3 (24), 2019 
вання), або використання зазначених емблем або слів як елемента знака для інших емблем або найменувань, або незаконне привласнення права використовувати символіку Червоного Хреста, Червоного Півмісяця, Червоного Кристала, або інші види незаконного використання символіки Червоного Хреста, Червоного Півмісяця, Червоного Кристала карається штрафом від трьох до чотирьох тисяч неоподатковуваних мінімумів доходів громадян.

2. Незаконне використання символіки Червоного Хреста, Червоного Півмісяця, Червоного Кристала або використання будь-якої іншої символіки, яка їх імітує для маркування товарів чи упаковок незалежно від їх призначення, карається штрафом від чотирьох до восьми тисяч неоподатковуваних мінімумів доходів громадян з конфіскацією майна.

3. Використання слів «Червоний Хрест», «Червоний Півмісяць», «Червоний Кристал» та комбінацій цих слів в усному вигляді, за умови, що дані слова використовуються не уповноваженою особою, шляхом шахрайського переконання, що така особа є співробітником (представником) Міжнародного червонохресного руху (імітування володіння статусом співробітника (представника) Міжнародного червонохресного руху), з метою отримання неправомірної вигоди матеріального чи нематеріального характеру карається штрафом від чотирьох до восьми тисяч неоподатковуваних мінімумів доходів громадян або позбавленням волі на строк до двох років

4. Дії, передбачені частиною першою або другою цієї статті, вчинені службовою особою суб'єкта господарювання або службовою особою міжнародного червонохресного руху, караються позбавленням волі на строк до п'яти років, з позбавленням права обіймати певні посади чи займатися певною діяльністю на строк до трьох років та 3 конфіскацією майна.

5. Носіння в районі воєнних дій символіки Червоного Хреста, Червоного Півмісяця, Червоного Кристала особами, які не мають на те права, або носіння в районі воєнних дій символіки, яка імітує символіку Червоного Хреста, Червоного Півмісяця, Червоного Кристала, а також зловживання в умовах особливого періоду або воєнного стану прапорами чи знаками Червоного Хреста, Червоного Півмісяця, Червоного Кристала, а також прапорами чи знаками, які імітують символіку Червоного Хреста, Червоного Півмісяця, Червоного Кристала або пофарбуванням, присвоєним санітарно-транспортним засобам, караються обмеженням або позбавленням волі на строк до двох років.

6. Дії, передбачені частинами першою або другою, або третьою, або п’ятою цієї статті, якщо вони спричинили тяжкі наслідки, караються позбавленням волі на строк від семи до дванадцяти років 3 конфіскацією майна.

7. Дії, передбачені частинами першою або другою, або третьою, або п'ятою, якщо вони поєднані з умисним вбивством, караються позбавленням волі на строк від десяти до п'ятнадцяти років або довічним позбавленням волі з конфіскацією майна.

Примітка:

1. У цій статті під неправомірною вигодою слід розуміти кошти чи інше майно, переваги, пільги, послуги або нематеріальні активи, які намагаються одержати чи одержують без законних на те підстав.

2. Тяжкими наслідками у статті $445,445^{1}$ вважаються такі наслідки, які у п'ятсот і більше разів перевищують неоподатковуваний мінімум доходів громадян або які характеризуються високим ступенем суспільної небезпечності злочинних діянь та тяжкості спричинених ними наслідків, зокрема, якщо заподіяні поранення, тяжкі тілесні ушкодження, загибель людей.

II. Виключити ст. 435 з КК України.

III. Доповнити Кримінальний кодекс України таким змістом: ст. 445-1 «Незаконне ввезення (пересилання) товарів, під виглядом гуманітарної допомоги на тимчасово окуповану 
територію України не підконтрольну органам державної влади України, на яких відсутня символіка Червоного Хреста, Червоного Півмісяця, Червоного Кристала, та їх використання»

1. Ввезення товарів під виглядом гуманітарної допомоги на тимчасово окуповану територію України, на яких відсутні представництва спеціально уповноважених державних органів України з питань гуманітарної допомоги, без офіційного дозволу Товариства Червоного Хреста України чи офіційного представництва міжнародного червонохресного руху на їх ввезення, на яких відсутня символіка Червоного Хреста, Червоного Півмісяця, Червоного Кристала, карається обмеженням або позбавленням волі на строк до двох років 3 конфіскацією майна.

2. Використання товарів під виглядом гуманітарної допомоги на тимчасово окупованій території України без офіційного дозволу товариства Червоного Хреста України чи офіційного представництва міжнародного червонохресного руху карається позбавленням волі на строк до двох років з конфіскацією майна.

3. Дії, передбачені частиною першою та другою, вчинені службовою особою суб'єкта господарювання або службовою особою міжнародного червонохресного руху, караються позбавленням волі на строк від трьох до п’яти років з конфіскацією майна.

4. Ті самі дії, якщо вони спричинили тяжкі наслідки, караються позбавленням волі на строк від семи до дванадцяти років з конфіскацією майна.

5. Ті самі дії, якщо вони поєднані з умисним вбивством, караються позбавленням волі на строк від десяти до п'ятнадцяти років або довічним позбавленням волі з конфіскацією майна.

IV. Викласти ст. $96^{3}$ Кримінального кодексу України в такій редакції:

«Підставами для застосування до юридичної особи заходів кримінально-правового характеру є:

1) вчинення її уповноваженою особою від імені та в інтересах юридичної особи будьякого із злочинів, передбачених у статтях 209 і 306, частинах першій і другій статті $368^{3}$, частинах першій і другій статті $368^{4}$, статтях 369 і $369^{2}$;

2) незабезпечення виконання покладених на ії уповноважену особу законом або установчими документами юридичної особи обов'язків щодо вжиття заходів із запобігання корупції, що призвело до вчинення будь-якого із злочинів, передбачених у статтях 209 і 306, частинах першій і другій статті $368^{3}$, частинах першій і другій статті $368^{4}$, статтях 369 і $369^{2}$;

3) вчинення ï уповноваженою особою від імені юридичної особи будь-якого із злочинів, передбачених у статтях 258-2585;

4) вчинення іiі уповноваженою особою від імені та в інтересах юридичної особи будьякого із злочинів, передбачених статтями $109,110,113,146,147$, частинами другою - четвертою статті $159^{1}$, статтями $160,260,262,436,437,438,442,444$, частиною четвертою статті 445 , частиною третьою статті $445^{1}$, статтею 447 цього Кодексу».

Примітка 1. Під уповноваженими особами юридичної особи слід розуміти службових осіб юридичної особи, а також інших осіб, які відповідно до закону, установчих документів юридичної особи чи договору мають право діяти від імені юридичної особи.

2. Злочини, передбачені статтями $109,110,113,146,147$, частинами другою - четвертою статті $159^{-1}$, статтями $160,209,260,262,306$, частинами першою і другою статті $368^{-3}$, частинами першою і другою статті $368^{-4}$, статтями $369,369^{-2}, 436,437,438,442,444$, частиною четвертою статті 445, частиною третьою статті $445^{1}$, статтею 447 цього Кодексу, визнаються вчиненими в інтересах юридичної особи, якщо вони призвели до отримання нею неправомірної вигоди або створили умови для отримання такої вигоди, або були спрямовані на ухилення від передбаченої законом відповідальності. 
V. Доповнити:

ч. 8 ст. 214 Кримінального процесуального Кодексу України частиною четвертою статті 445 та частиною третьою статті $445^{1}$ Кримінального Кодексу України.

У зв'язку з тим, що ст. 445 КК України $є$ бланкетною нормою, дослідження проблематики вдосконалення законного використання символіки повинно стосуватись також інших норм чинного законодавства України, які регулюють законність використання символіки.

Так, метою кримінально-правової протидії незаконному використанню символіки є зниження рівня злочинних дій, пов'язаних із незаконним використанням символіки. Завданням протидії незаконному використанню символіки є конкретна програма дій, зорієнтованих на досягнення поставленої мети. Для цього необхідно створення відповідних контролюючих підрозділів у Товаристві Червоного Хреста України, які будуть здійснювати контроль за правомірністю використання символіки Червоного Хреста, Червоного Півмісяця, Червоного Кристала.

На підставі вищевикладеного доцільно внести зміни, а саме доповнити:

a) ст. 9 Закону України «Про Товариство Червоного Хреста України» таким змістом:

- здійснює контроль за законністю використання символіки Червоного Хреста, Червоного Півмісяця, Червоного Кристала. Рекомендації та висновки уповноважених контролюючих органів Товариства Червоного Хреста України обов'язково розглядаються органами досудового розслідування в першочерговому порядку;

- тимчасово виконує функції спеціально уповноважених державних органів 3 питань гуманітарної допомоги, згідно з Законом України «Про гуманітарну допомогу» від 22.10.1999 № 1192-XIV, на тимчасово окупованій території України, на якій відсутні представництва спеціально уповноважених державних органів України з питань гуманітарної допомоги; [2]

б) ст. 3 Статуту Товариства Червоного Хреста України таким змістом: в кожній організації національного (центрального) та регіонального рівня створюється орган, відповідальний за здійснення контролю за законністю використання символіки Червоного Хреста, Червоного Півмісяця, Червоного Кристала в Україні. [7]

Згідно із Законом України «Про Товариство Червоного Хреста України» від 28.11.2002 № 330-IV, Товариство Червоного Хреста України (далі - Товариство) є всеукраїнською добровільною громадською гуманітарною організацією. Товариство допомагає державі у наданні медичної і гуманітарної допомоги під час збройних конфліктів та в мирний час, бере участь у наданні міжнародної допомоги у разі катастроф і надзвичайних ситуацій, забезпечує медико-соціальну допомогу найменш соціально захищеним верствам населення. [2]

Сьогодні законодавчо не врегульованим $€$ питання надання гуманітарної допомоги населенню в районі проведення операції об'єднаних сил. У ході вивчення статистичних спостережень соціальних мереж, інформаційних сайтів, засобів масової інформації встановлено систематичну закономірність посилення бойових дій на межі розмежування після направлення гуманітарних конвоїв Російською Федерацією на тимчасово неконтрольовану територію України.

Один з основних напрямів міжнародного червонохресного руху, складником якого $є$ Товариство Червоного Хреста України, - надання гуманітарної допомоги під час збройних конфліктів та в мирний час найменш соціально захищеним верствам населення.

Таким чином, у цій ситуації надання гуманітарної допомоги населенню, що мешкає на тимчасово неконтрольованій території України, повинно здійснюватись через Товариство Червоного Хреста України або представників міжнародного червонохресного руху.

У зв'язку з тим, що натепер це питання законодавчо не врегульовано, доцільно внести зміни до таких нормативних актів, а саме: 
1. Доповнити:

a) ст. 5 Закону України «Про гуманітарну допомогу» від 22.10.1999 № 1192-XIV таким змістом: «на тимчасово окупованій території України, на якій відсутні представництва спеціально уповноважених державних органів України з питань гуманітарної допомоги, тимчасово виконує їх функції товариство Червоного Хреста України або офіційні представництва міжнародного червонохресного руху»;

б) ст. 9 Закону України «Про гуманітарну допомогу» від 22.10.1999 № 1192-XIV таким змістом: «на тимчасово окупованій території України, на якій відсутні представництва спеціально уповноважених державних органів України з питань гуманітарної допомоги, дозволяється ввезення лише гуманітарної допомоги, які пройшли контроль товариством Червоного Хреста України або офіційним представництвом міжнародного червонохресного руху. На гуманітарну допомогу, яка ввозиться на тимчасово окуповану територію України, обов'язково наноситься символіка Червоного Хреста, Червоного Півмісяця, Червоного Кристала товариством Червоного Хреста України або офіційними представниками міжнародного червонохресного руху. Перевезення гуманітарної допомоги на тимчасово окупованій території України здійснюється обов'язково у присутності представника товариства Червоного Хреста України або офіційного представництва міжнародного червонохресного руху. Гуманітарна допомога доставляється тільки за адресами розташування офіційних представництв товариства Червоного Хреста України або офіційних представництв міжнародного червонохресного руху. Ввезення гуманітарної допомоги на тимчасово окуповану територію України, на якій відсутні представництва спеціально уповноважених державних органів України з питань гуманітарної допомоги, без офіційного дозволу товариства Червоного Хреста України чи офіційного представництва міжнародного червонохресного руху та без нанесення на товари символіки Червоного Хреста, Червоного Півмісяця, Червоного Кристала заборонено. Оплатне відчуження даних товарів на тимчасово окупованій території України забороняється»;

в) ст. 12 Закону України «Про гуманітарну допомогу» від 22.10.1999 № 1192-XIV таким змістом: «також порушеннями законодавства про гуманітарну допомогу, що тягне за собою кримінальну відповідальність згідно із законом, є ввезення (пересилання) товарів під виглядом гуманітарної допомоги на тимчасово окуповану територію України, на якій відсутні представництва спеціально уповноважених державних органів України з питань гуманітарної допомоги, та їх подальше використання без символіки Червоного Хреста, Червоного Півмісяця, Червоного Кристала або без офіційного дозволу товариства Червоного Хреста України або офіційного представництва міжнародного червонохресного руху» [8].

Для вирішення проблеми покращення правозастосування ст. 445 КК України доцільно внести зміни до частини 1 ст. 15 Закону України «Про символіку Червоного Хреста, Червоного Півмісяця, Червоного Кристала в Україні».

Частину 1 статті 15 Закону України «Про символіку Червоного Хреста, Червоного Півмісяця, Червоного Кристала в Україні» викласти в такій редакції:

Забороняється використання емблем Червоного Хреста, Червоного Півмісяця, Червоного Кристала, комбінацій цих емблем; слів «Червоний Хрест», «Червоний Півмісяць», «Червоний Кристал», комбінацій цих слів як у письмовому, так і в усному вигляді; розпізнавального знака чи будь-якого іншого знака, найменування або сигналу, які являють собою імітацію (використання подібних кольорів або зображень) або можуть призвести до змішування, незалежно від мети такого використання, з порушенням положень цього Закону і Правил [5].

Висновки. Можливо зробити висновок, що $є$ нагальна потреба в законодавчому перегляді формулювання вищевказаних статей Кримінального Кодексу України. Запровадження національних заходів, спрямованих на дотримання законного використання симво- 
ліки Червоного Хреста, Червоного Кристала та Червоного Півмісяця, є важливим фактором підтримки неупередженості й нейтральності, пов'язаної з наданням гуманітарної допомоги. Невжиття державою відповідних заходів може призвести до зловживань у використанні емблеми та зменшить рівень поваги до неї. Варто також мати на увазі, що нездатність органів влади присікти зловживання символікою Червоного Хреста, Червоного Півмісяця і Червоного Кристала в мирний час спростить зловживання ними під час збройного конфлікту. Вдосконалення норм законодавства України щодо незаконного використання символіки Червоного Хреста, Червоного Півмісяця, Червоного Кристала створить правове підгрунтя для перенесення розглядуваного злочину в практичну площину.

\section{Список використаних джерел:}

1. Митний кодекс України. URL: http://zakon3.rada.gov.ua/laws/show/4495-17 (дата звернення: 26.07.2019).

2. Про Товариство Червоного Хреста України : Закон України від 28.11.2002 № 330-IV. URL: http://zakon4.rada.gov.ua/laws/show/330-15 (дата звернення: 26.07.2019)

3. Податковий кодекс України. URL: zakon.rada.gov.ua/laws/show/2755-17 (дата звернення: 26.07.2019).

4. Науково-практичний коментар до Кримінального кодексу України : у 2 т. / за заг. ред. П.П. Андрушка, В.Г. Гончаренка, С.В. Фесенка. 3-тє вид., перероб. та доп. Київ : Алерта : КНТ : Центр учбової літератури, 2009. Т. 2. 624 с.

5. Про символіку Червоного Хреста, Червоного Півмісяця, Червоного Кристала в Україні : Закон України від 08.07.1999 № 862-XIV URL: http://zakon4.rada.gov.ua/laws/ show/862-14 (дата звернення: 26.07.2019).

6. Українське кримінальне право. Загальна частина : підручник / П.С. Берзін та ін. ; за заг. ред. В.О. Навроцького. Київ : Юрінком Інтер, 2013. 711 с.

7. Статут Товариства Червоного Хреста України: Затверджений XV з'їздом Товариства Червоного Хреста України 04.04.1991. Київ : Товариство Червоного Хреста України, 2001. 44 c.

8. Про гуманітарну допомогу : Закон України від 22.10.1999 № 1192-XIV URL: https://zakon.rada.gov.ua/laws/show/1192-14 (дата звернення: 26.07.2019). 
УДК 347.68:(007:004.73)

DOI https://doi.org/10.32836/2521-6473-2019-3-119-123

\author{
С. С. Аліна, аспірант кафедри \\ цивільного права Національного університету \\ «Одеська юридична академія»
}

\title{
ФАКТОРИ, ЩО ВИКЛЮЧАЮТЬ МОЖЛИВІСТЬ ТРАДИЦЙНОГО СПАДКУВАННЯ ЦИФРОВИХ ОБ'ЄКТІВ
}

Стаття присвячена питанню визначення правової природи ицфрових об'єктів як об'єктів спадкових прав. Визначено, що особливості IT-об'єктів виступають перешкодами для застосування чинних норм законодавства, які визначають процедуру спадкування иивільних прав. Серед принцинових особливостей ичифрових об'єктів, щчо є перепонами для традииійного спадкування, визначено такі: динамічність існування IT-об'єктів; анонімність та знеособлення в питаннях володіння та використання окремих IT-об'єктів; знаходження окремих об' 'ктів поза межами впливу держави та національного законодавства; нетрадиійність способів монетизації окремих об 'єктів IT; невизначеність реальної та потенційної цінності окремих об'єктів. 3'ясовано, щяо динаміка виникнення i існування IT-об'єктів знаходить свій вияв у трьох ключових факторах: максимальній швидкості їх виникнення та поширення; стрімкому розширенні сфери застосування та видозміні первинного об'єкта; раптовості їх занепаду та зникнення через заміну новими об'єктами. Доведено, що держава нерідко не включена до тієї системи відносин, щзо формуються щодо конкретного цииррового об'єкта, а отже, потребується значний об'єм науково-дослідної, законотворчої та правозастосовчої роботи для врегулювання відносин щчодо ицфрових об'єктів та включення ичих відносин до усталеної системи внутрішньодержавних цивільних правовідносин. Виокремлено функціональні недоліки державної політики у сфері регулювання відносин щодо иифрових об'єктів: невизнання окремих IT-об'єктів, недоочінка їх значення для сучасного суспільства, відсутність технічних механізмів впливу на такі відносини. Доведено значення анонімізації в мережі для спадкового потенціалу окремих иифрових об 'єктів у мережі. Доведено, що неможливість визначити особу власника прав на конкретний цифровий об' єкт стане значною перепоною для його можливого спадкування в разі смерті правовласника.

Ключові слова: фактори, цифровий об'єкт, конфіденційність, анонімність, традиційне спадкування, правовий режим спадкового майна.

\section{S. S. Alina. Factors excluding the possibility of traditional inheritance of digital objects}

The article is devoted to the determination of the legal nature of digital objects as objects of inheritance rights. It has been determined that the features of digital objects constitute obstacles to the application of the current legislative norms that determine the procedure for inheriting civil rights. Among the principal features of digital objects, which are obstacles to traditional inheritance, the following are identified: the dynamic existence of IT objects; anonymity and depersonalization in matters of ownership and use of individual IT objects; the location of individual objects beyond the influence of the state and national legislation; unconventional methods of monetization of individual IT objects; the uncertainty of the real and potential value of individual objects. It is established that the dynamics of the emergence and existence of IT objects finds its expression in three key factors: the maximum speed of their occurrence and distribution; the rapid expansion of the scope and modification of the primary object; the suddenness of their decline and disappearance due to the replacement of new objects. It is proved that the state is often not included in the system of relations that are formed around a particular digital object, and therefore a significant amount of research, legislative and law enforcement work is required to resolve relations regarding digital objects and include these relations in the system of domestic civil relations. The following functional shortcomings of state policy in the field of regulation of relations regarding digital objects are highlighted: non-recognition of individual

(C) С. С. Аліна, 2019

ISSN 2521-6473

Правова позиція, № 3 (24), 2019 
IT objects, underestimation of their importance for modern society, lack of technical mechanisms for influencing such relations. The importance of anonymization in the network for the hereditary potential of individual digital objects in the network is proved. It was determined that the inability to determine the identity of the owner of the rights to a specific digital object will become a significant obstacle to its possible inheritance in the event of the death of the copyright holder. property.

Key words: factors, digital object, privacy, anonymity, traditional inheritance, legal mode of hereditary

Постановка проблеми. Процедура переходу прав на майно від померлого до іншої особи почала оформлюватися ще в період формування в людства уявлень про такі права на майно. Обмеженість часу життя людини вимагало розуміння, як визначатиметься доля речей, що належать особі. Сформовані ще римськими юристами стандарти, що застосовуються для відносин спадкування, були перейняті вітчизняним законодавцем під час прийняття Цивільного кодексу України. Еволюційні зміни суспільних відносин на сучасному етапі розвитку людства призвели до розширення можливостей спадкування. До складу спадщини стало можливим включати широке коло майнових прав, а також ряд немайнових прав, які можуть бути відчужені. Діджиталізація суспільного життя у XXI сторіччі призвела до появи нових об'єктів права, права щодо яких здійснюються фізичними особами, а отже, виникла необхідність визначення їх статусу як об'єкта спадкових відносин.

Стан дослідження теми. Науковці, які піднімали питання спадкування IT-об'єктів, не приділяли уваги визначенню причин невідповідності законодавчо закріплених процедурних форм спадкування вимогам сучасних відносин щодо цифрових об'єктів. Також відсутня й юридична практика спадкування цифрових об'єктів через незначний період використання подібних об'єктів у повсякденному житті, відносну молодість авторів та власників таких об'єктів та невизначеність остаточного комерційного потенціалу останніх. Саме тому мета даного дослідження - виокремити ті обставини, що на сьогодні перешкоджають застосуванню чинних правових механізмів під час спадкування об'єктів IT-середи.

Виклад основного матеріалу. Як вже зазначалося, природа ІТ-об'єктів різниться в залежності від виду технологій, що застосовуються для створення, зміни, обслуговування або використання окремого об'єкта IT-середи. Однак можна виділити ряд характерних особливостей, які прямо або опосередковано властиві більшості цифрових об'єктів та впливають на можливість їх потенційної передачі у спадок у випадку смерті власника.

Для визначення конкретних перепон спадкуванню таких об'єктів за загальними правилами необхідно окремо проаналізувати особливості IT-об'єктів, які визначають їх правову природу як об'єктів спадкування. Перш за все, слід виділити такі:

- динамічність існування ІТ-об'єктів;

- анонімність та знеособлення в питаннях володіння та використання окремих ІТ-об’єктів;

- знаходження окремих об'єктів поза межами впливу держави та національного законодавства;

- нетрадиційність способів монетизації окремих об'єктів IT;

- невизначеність реальної та потенційної цінності окремих об'єктів.

Динаміка виникнення і існування IT-об'єктів знаходить свій вияв одразу в трьох ключових для можливості їх коректного правового регулювання факторах: максимальній швидкості їх виникнення та поширення; стрімкому розширенні сфери застосування та видозміні первинного об'єкта; раптовості їх занепаду та зникнення через заміну новими об'єктами.

Перший фактор фактично виключає можливість законодавству встигати за розвитком інформаційних технологій і об'єктами, які породжуються завдяки цим технологіям. Крім того, 
важливе значення має той факт, що значна частина IT-об’єктів сьогодні впроваджуються незалежними від держави користувачами інформаційних технологій, як це бачимо на прикладі криптовалют. Держава найчастіше не включена до тієї системи відносин, що формуються щодо того чи іншого цифрового об'єкта, а отже, потребується значний об'єм науково-дослідної, законотворчої та правозастосовчої роботи для врегулювання відносин щодо цифрових об'єктів та включення цих відносин до усталеної системи внутрішньодержавних цивільних правовідносин.

Окремо необхідно зазначити про стрімке розширення кола IT-об'єктів, що мають цінність у сенсі правого регулювання. Так, наприклад, ще 14 років тому відеохостинг YouTube представляв собою платформу для пошуку відеороликів [5] без стабільної аудиторії та конкретних комерційних перспектив для авторів самих відеофайлів. На сьогодні прибуток від окремих каналів із вітчизняної зони YouTube досягає 100 тисяч доларів США на місяць [6]. Відеохостинг фактично пройшов трансформацію від онлайн-галереї відео через формат особистих відеоблогів до платформи з фактично безмежними можливостями транслювання інформації в багатомільйонну мережу користувачів із метою досягнення широкого спектру завдань. YouTube - перший у топ-10 сайтів, які українці відвідують щомісяця, і перший, де найдовше українці проводять часу (більше 20 хвилин в день). А в Україні 40,9 млн. інтернет-користувачів, і 72\% із них користуються Інтернетом щодня [4].

У свою чергу, канал на платформі ҮouTube від приватної ініціативи у вільний час перетворився на цілком оформлений об'єкт цивільних відносин. Об'єктивація таких каналів підтверджується включенням їх до правовідносин купівлі-продажу, міни, надання послуг, правовідносин щодо здійснення та захисту прав інтелектуальної власності тощо. На сьогодні ні вітчизняне законодавство, ні юридична доктрина не дали відповіді на питання визначення юридичної природи передачі прав на ҮouTube-канал, попри той факт, що фактично існує вільний ринок продажу таких прав, а користувачі звертаються до методів убезпечення таких угод за допомогою неправових заходів [3]. Держава залишається осторонь і у визначенні правового режиму таких об'єктів у спадкових правовідносинах.

У той же час необхідно констатувати, що стрімкий розвиток відеоблогінгу, підвищення попиту на послуги пов'язані з виробленням аудіовізуального контенту для подальшого розміщення в мережі Інтернет, запровадження нових технологічних рішень від самого відеохостингу (потокове live-відео, платні підписки, інтерактивність самих відео і широкі можливості зворотного зв'язку з користувачами хостингу) розширюють сферу застосування каналів на YouTube, здійснюючи розшарування такого об'єкта, як персональний канал на відеохостингу, на окремі підвиди. Так, наприклад, вже сьогодні канали на YouTube виступають повноцінними 3МI та медіа-ресурсами з розважальним контентом, базами даних із відео-оглядами товарів із конкретних магазинів, систематизованими базами знань із конкретних питань, персональним сховищем для результатів творчості тощо. Кардинально різні цілі авторів таких каналів та принципово відмінні можливості від використання таких об’ єктів означають також і різні сфери їх застосування, а отже, й неоднорідність правового режиму здійснення та захисту прав на такі об'єкти. Крім того, збільшення кількості «форм-факторів» для такого об'єкта, як YouTube-канал, створює умови для виникнення похідних IT-об'єктів, права на які також потребують правового регулювання, та недостатність правових механізмів для їх захисту [7] (наприклад, знедавна поширене питання про захист інтелектуальних прав на «формат відеоконтенту»).

Стрімкий розвиток інформаційних технологій призводить до швидкої заміни одних технологічних рішень іншими, більш сучасними, економічно вигіднішими або доступнішими. Періодична зміна пріоритетів у виборі інформаційних технологій, що використовуються для формування тих чи інших цифрових об’єктів, накладає відбиток і на значення таких об'єктів 
для суспільства. Таким чином, може зникати необхідність правового регулювання відносин, що виникають щодо таких об'єктів через втрату ними значення для суспільства. Крім того, еволюція ІТ-об'єктів та специфіка форми їх існування безпосередньо впливає й на спосіб їх передачі від спадкодавця до спадкоємця, а також на форму заповіту.

Приклад майже цілковитого зникнення цілого ряду носіїв інформації, таких як дискети, касети VHS та аудіокасети, свідчить про неможливість гарантування збереження цифрового об'єкта для подальшого його спадкування в оригінальному вигляді та необхідність розроблення й підтримання актуального носія не тільки для самого IT-об'єкта, а й для інформації, яка забезпечує доступ до такого об’єкта.

Якщо говорити про конфіденційність як критичну відмінність відносин у сфері Інтернет, то іiі вплив на межі здійснення суб'єктивних цивільних прав щодо окремих об'єктів у мережі Інтернет є потенційно визначальним. На відміну від традиційних цивільних відносин у реальному житті, де анонімність відносно неможлива, відносини у сфері Інтернет можуть набувати абсолютно знеособлених форм. Так, наприклад, тематичні канали в месенджері Telegram, канали на відеохостингу YouTube, сторінки в Instagram та подібні до них об'єкти можуть мати абсолютно анонімний характер, підкріплений можливостями програмного забезпечення самих інтернет-ресурсів у питаннях забезпечення анонімності, а також можливостями VРNта інших технологій забезпечення анонімності в мережі Інтернет.

Попри супротив окремих держав анонімізації мережі Інтернет, тенденції розвитку міжнародного права свідчать про те, що анонімність в Інтернеті належить до прав людини. Такого висновку, наприклад, дійшла Рада 3 прав людини Організації об'єднаних націй, яка представила у 2015 році звіт засідання, присвяченого анонімності та шифруванню в інтернеті. Засоби анонімізації і шифрування названі у звіті «необхідними для того, щоб людина була вільною у вираженні своєї думки в цифрову епоху». У документі наголошується, що хоча такі засоби і можуть використовуватися зловмисниками для вчинення злочинів, той же самий телефон можна використовувати як для того, щоб задумати злодіяння, так і для повідомлень у поліцію [1].

Європейська Хартія про права людини у статті 9 визнає право кожного на захист особових даних [2]. Право на приватність розуміється як можливість людини мати і підтримувати контроль за інформацією, що стосується іiі.

Визнаючи потенціал можливої анонімізації в Інтернеті, в майбутньому можна констатувати, що неможливість визначити особу власника прав на конкретний цифровий об'єкт стане значною перепоною для його можливого спадкування в разі смерті правовласника. На відміну від телевізійного каналу, діяльність якого регулюється державою, YouTube-канал або сторінка в Instagram, фактично виконуючи роль повноцінного транслятора інформації, можуть зберігати анонімність автора, правовласника або особи, яка поширила дану інформацію за допомогою належного їй YouTube-каналу, сторінки в Instagram тощо.

Поряд із вольовим проявом анонімізації відносин у мережі Інтернет (свідомими діями особи-власника прав на конкретний цифровий об'єкт для забезпечення конфіденційності здійснення нею своїх прав) на сьогодні в мережі Інтернет існує також тенденція знеособлення авторства певного контенту або суб'єкта володіння певними цивільними правами щодо окремого цифрового об'єкта. Такий прийом використовується у випадку наявності декількох авторів контенту або більшої питомої ваги того бренду, під яким розміщується той чи інший цифровий контент.

Ще одним фактором, що унеможливлює використання наявних механізмів спадкування, виступає вже згадувана відмова держави від регулювання цілих сфер суспільних відносин шляхом невизнання окремих ІТ-об'єктів, недооцінки їхнього значення для сучасного суспільства, відсутності технічних механізмів впливу на такі відносини (в тому числі невдалі спроби регу- 
лювання таких відносин). Класичним прикладом виступають відносини щодо володіння та розпорядження криптовалютними гаманцями в Україні, адже згідно з листом Національного банку України від 8 грудня 2014 р. випуск віртуальної валюти Bitcoin не має будь-якого забезпечення та юридично зобов'язаних за нею осіб, не контролюється державними органами влади жодної iз країн, а отже, є грошовим сурогатом, який не має забезпечення реальної вартості [8]. У цьому випадку максимальна формалізація підходу до визначення природи криптовалюти Вitcoin залишила без регулювання швидко зростаючий ринок торгівлі криптовалютними активами.

Висновки. Резюмуючи вищезазначене, можна зробити висновок, що властивості природи ІТ-об'єктів, особливо створених або розміщених у мережі Інтернет, виключають можливість поширення на них режиму спадкового майна або цивільних прав, що можуть бути успадковані у традиційному порядку за законом або заповітом.

\section{Список використаних джерел:}

1. Charter of Fundamental Rights of the European Union. ELI: URL : http://data.europa.eu/ eli/treaty/char 2012/oj.

2. Анонімність в Інтернеті належить до прав людини - OOH. Закон і бізнес. 2015. URL : https://zib.com.ua/ua/116597-anonimnist_v_interneti_nalezhit_do_prav_lyudini_-_oon.html.

3. Законна ликупля-продажа канала Youtube? URL : https://firstvideoseo.com/pokupkakanala-youtube-zakonno-li/.

4. Какменялся YouTube за 12 лет: эволюция видеохостинга. URL : https://podrobnosti.ua/ 2187879-kak-menjalsja-youtube-za-12-let-evoljutsija-videohostinga.html.

5. Лист Національного банку «Щодо віднесення операцій з віртуальною валютою/криптовалютою «Bitcoin» до операцій з торгівлі іноземною валютою, а також наявності підстав для зарахування на поточний рахунок в іноземній валюті фізичної особи іноземної валюти, отриманої від продажу Bitcoin» № 29-208/72889 08.12.2014 p. URL : http://zakon0.rada.gov.ua/ laws/show/v2889500-14.

6. Нелегкие деньги. ЭП раскрывает доходы топ-10 ҮouTube-каналов. Экономическая правда. URL : https://www.epravda.com.ua/rus/publications/2016/05/10/592102/.

7. Проверка авторских прав на YouTube. URL : https://academy.air.io/blog/proverkaavtorskikh-prav-na-youtube.

8. Свій YouTube-канал: с чего начать. На примереюр компании. URL : http://loyer.com.ua/ ru/svoj-youtube-kanal-s-chego-nachat-na-primere-yurkompanii/. 
УДК 342.7: 343.3

DOI https://doi.org/10.32836/2521-6473-2019-3-124-128

\author{
€. В. Баранова, студентка III курсу \\ Інституту підготовки кадрів для органів юстиції \\ України Національного юридичного університету \\ імені Ярослава Мудрого
}

\title{
ПРАВО НА ЗАХИСТ ВИКРИВАЧІВ КОРУПЦІЇ: КОНСТИТУЦЙНИЙ АСПЕКТ
}

Інститут викривачів є важливим запобіжником поширення такого явища, як корупція у суспільстві. Корупиіонери і у державному, $і$ у приватному секторі згубно впливають на подальший розвиток державної економіки та України в цілому. Через це на цей момент проблематика реалізації викривачами їх діяльності та створення механізму їх захисту від гніту «верхівки» залишається актуальною. У иій роботі представлені питання правової природи інституту викривачів та співвідношення діяльності з засобами їх захисту після викриття інформаиії, здійснюється аналіз як міжнародних, так і начіональних правових норм, що його забезпечують, звертається увага на необхідність для суспільства даних відомостей. Важливим аргументом «за» є саме розуміння того, що корупиія - ие явище, яке прогресує у політичній, економічній сферах життя населення і є однією з основних причин гальмування демократичного розвитку України. Розкривається проблема реалізаиії конституційного права на захист кожної особи в аспекті захисту прав вищезгаданих осіб. Адже його слід розглядати саме як основоположне й загальне, разом з правами людини на життя, гідність, недоторканність. Саме тому, говорячи про закріплення у Конституиії України права на захист, важливо розуміти, що воно лише відкриває перспективи для наступної деталізаиії иього права в окремих галузях законодавства та їх дослідження. Досліджено мету прийняття та конституційність норм, щзо містяться у проекті Закону України «Про захист викривачів корупиї̈». На жаль, хоча й наявні певні векторні зрушення стосовно захисту whistblowers, але законопроект потребує подальшого вдосконалення та суттєвого доопрачювання, бо має досить обмежений та вузький предмет регулювання, а сфера відносин та діяльності викривачів нині не обмежується викриттям корупиійних порушень та відповідного контексту захисту викривачів. Розкритий теоретичний аспект изього питання знаходить підтвердження $і$ на практииі. Так, у статті наведено до розгляду позииї Європейського Суду з прав людини та рекомендаиії Ради Європи, а також пріоритетні напрями подальшого розв'язання вказаної проблематики.

Ключові слова: права людини, корупція, викривачі, захист, розкриття інформаиії, конституційність, гарантії, суспільний інтерес.

\section{E. V. Baranova. Right of whistleblower's legal protection: constitutional aspect}

Whistleblowers are an important source of different cases and they often provide pivotal records for a successful prosecution. Institute of whistleblowers is an important protective measure of the corruption spreading in society. Corruptors in both spheres, public and private, inhibit the further development of State's economy and whole Ukraine. That's why, in this article the questions of the legal nature of whistleblower's institute and the correlation of their activity and consequences are presented; analyze international and national rules of law. However, the main aspect is how much do our society need this information? In this work we reveal the problem of constitutional right's realization, for instance, right of protection in connection with whistleblower's information disclosure. After all, it should be regarded as fundamental and general, on a pare with human rights to life, dignity, integrity etc. Detection through whistleblower reporting to law enforcement authorities is rarely discussed in public by such authorities because of the need to protect the whistleblowers involved. We should admit that protection should be afforded to whistleblowers regardless of their motives in making the disclosure and regardless of whether they report directly to law enforcement, or report internally - first within the company, or to the media, an elected government official or to civil society (for example, an advocacy group or a non-governmental organisation). Whistleblowers must know where, how, and when to report; that their identity as a whistleblower will be kept confidential; and also that they will be protected with anti-retaliation

(C) С. В. Баранова, 2019 
remedies. Raising awareness of the importance of whistleblowers can promote a "speak up" culture and de-stigmatise the disclosure of wrongdoing. One of the most successful and popular method to protect and encourage whistleblowers is to create a system of making anonymous or confidential reports. Furthermore, anonymous reporting includes concealment of whistleblower's identity, espacially in small companies or small countries. From a practical perspective, it is also difficult to provide comprehensive protection to a person whose identity is unknown but that could be deduced by potential retaliators for the reasons described above. It is important to understand that when we speaking about the right of protection in context of Constitution of Ukraine, this is only the main cause to start detailing study of this right in certain branches of legislation and their research. Explore the purpose of adoption and constitutionality of the rules of law which are contained in the draft Law of Ukraine "On Protection of Corruptors of Corruption" is investigated. The positions of the European Court of Human Rights and the recommendations of the Council of Europe are discussed, as well as priority directions for further resolution of these issues. In such way, the conclusion note is that whistleblowers must have effective legal protection in the form of guaranteed confidential reporting and anti-retaliation protections and we need to resolve this problem as soon as possible.

Key words: human rights, corruption, whistblowers, protection, disclosure information, constitutionalism, warranties, public interest.

Постановка проблеми. Політика сучасного світу здебільшого орієнтована на боротьбу 3 корупцією як з гальмівним фактором розвитку держави. Однак у цих перегонах невирішеним залишається питання про реалізацію людиною її права на захист від переслідувань через викриття корупціонерів. Хто вони - викривачі корупції? Та від чого їх варто захищати? Саме тому доцільним буде проаналізувати міжнародний та національний досвід та визначити пріоритетні вектори подальших зусиль.

Аналіз останніх досліджень та публікацій. Методологічну основу дослідження вказаної проблематики становлять праці таких вітчизняних та іноземних науковців, як Р. Вон, О.Ю. Шостко, О.М. Калітенко, О.С. Тимченко, О.В. Нестеренко, М.В. Буроминський, С.Г. Братель, М.Г. Колодяжний, О.В. Линник, Геральд Г.Мой, та ряду інших вчених та юристів-практиків.

Мета статті полягає у розкритті питання правової природи інституту викривачів крізь призму співвідношення конституційного права на захист з реально наявними механізмами гарантування безпеки викривачів корупції.

Виклад основного матеріалу. Право на захист зазвичай розглядається науковцями в досить широкому розумінні й охоплює максимальний спектр суспільних відносин, 3 приводу яких воно застосовується. На наш погляд, слід розглядати його саме як основоположне й загальне, разом з правами людини на життя, гідність, недоторканність. Це право не регламентовано конкретно у нормативно-правових актах, таких як Конвенція про захист прав людини і основоположних свобод тощо, а тлумачиться крізь призму детального аналізу ряду інших норм про права людини. Текст Конституції України, зокрема, свідчить про вияв сутності права на захист у нормах, присвячених правовій регламентації інших суспільних відносин: право на звернення до суду для захисту конституційних прав і свобод людини і громадянина безпосередньо на підставі Конституції України (ст. 8); право на звернення за захистом своїх прав до Уповноваженого Верховної Ради України з прав людини, до міжнародних судових установ (ст. 55); право на захист обвинуваченого чи підсудного (ст. 63); право на захист від обвинувачення (ст.59) тощо. Слід зауважити, що в тексті Конституції міститься належне формулювання, котре може регламентувати право кожної людини, зокрема, права викривачів корупції на захист у загальному його розумінні: «Кожен має право будь-якими не забороненими законом засобами захищати свої права і свободи від порушень і протиправних посягань» [1].

Постає питання: «Захист “whistleblowers” від чого?» Розкриваючи інформацію, яка $є$ важливою для населення, доброчесні інформатори в умовах юридичної незахищеності зустріча-

ISSN 2521-6473

Правова позиція, № 3 (24), 2019 
ються з переслідуваннями та утисками, дискримінацією та репресіями на роботі: позбавлення премій, переведення на нижчу посаду та навіть звільнення, при цьому не маючи чітко передбаченого механізму подальших дій, який водночас потребує наступного регулювання.

Інститут викривачів $€$ важливим запобіжником поширення такого явища, як корупція у суспільстві. Корупціонери і у державному, і у приватному секторі згубно впливають на подальший розвиток державної економіки та України в цілому та покладаються на мовчання людей, іноді навіть шляхом залякування. Якщо пересічні громадяни перестануть мовчати про корупційні діяння, свідками яких вони стали, то потенційний корупціонер подумає тричі перед отриманням хабаря чи вчиненням незаконних дій, а вже викриті факти підвищать рівень несприйняття корупції суспільством. Однак чого буде варто людям викриття високопоставлених осіб?

Сьогодні можна беззаперечно стверджувати, що інститут викривачів або доброчесних інформаторів - осіб, які за наявності обгрунтованого переконання, що інформація є достовірною, повідомляють про порушення вимог Закону України «Про запобігання корупції» іншою особою, є важливим методом подолання корупційних правопорушень [2]. Варто усвідомити, що вони не $\epsilon$ «донощиками», а $\epsilon$ насамперед свідомими громадянами, які закладають фундамент системи раннього попередження порушення.

Наслідком їх діяльності є зупинення корупційних злочинів, перемога хабарів, поступова зміна цілісної системи, утвердження панування верховенства права, покращення системи державного управління, відновлення соціальної справедливості та ряд інших переваг. Однак за цим стоїть гніт "whistleblowers" з боку роботодавців, зацікавлених третіх осіб, який іноді супроводжується погрозами. Тому не менш необхідним чинником протидії та запобігання корупції є й право на захист цих осіб. Адже разом з відсутністю захисту зростає ймовірність збільшення корупційних проявів у суспільстві.

Відомий американський професор Р. Вон у своїй монографії називає службові викриття протиотрутою від бюрократичного зла [3, с. 236]. Однак йдеться не лише про розкриття корупційних проявів в умовах зловживання владою, а й про порушення прав людей, виробництво продуктів харчування, ліків з речовин, що шкідливі для здоров'я людини, екологічно небезпечні викиди в атмосферу.

На міжнародному рівні за останні роки більш ніж 30 країн світу розробили спеціальні закони або включили гарантії права захисту викривачів у антикорупційне, трудове законодавства або в етичні кодекси працівників. До таких країн належать Сполучені Штати Америки, Австралія, Республіка Сербія, Японія, Велика Британія та багато інших. У цих країнах викривачі отримали і визнання від громадськості, адже про це свідчать пам'ятники викривачам Сноудену, Асанжу, Меннінгу в Женеві, демонстрації на підтримку запровадження захисту викривачів у Брюсселі, а також щорічна міжнародна премія International Whistleblowing Prize та премія «За мужність» у США. У деяких країнах навіть закріплена система фінансового заохочення доброчесних інформаторів [4, с. 146].

Вперше необхідність саме законодавчого врегулювання інституту захисту інформаторів було відображено у ст. 22 Кримінальної, ст.9 Цивільної конвенції Ради Свропи про боротьбу 3 корупцією, а також ст. 33 Конвенції ООН проти корупції [5]. Саме в останній міститься зауваження, що кожна держава-учасниця має можливість включення до внутрішньої правової системи належних заходів для забезпечення захисту будь-яких осіб, які на обгрунтованих підставах повідомляють відповідним правоохоронним органам про злочини, передбачені цією Конвенцією [6].

Законодавчо закріплені норми підтверджуються i на практиці. Прикладами цього $\epsilon$ справа офіцера поліції Нью Йорка Ф. Серпико, який виступив зі свідченнями щодо випадків корупції, наочним підтвердженням є й рішення Європейського Суду з прав людини у справі 
Guja v. Moldova № 14277/04, в якому було визнано, що Молдова порушила ст.10 Європейської конвенції про права людини, коли вона звільнила державного службовця, який розкрив інформацію, яка представляє суспільний інтерес про спроби високопоставлених політиків впливати на судову систему. Суд постановив, що ст.10 поширюється як на державних службовців, так і на робочі місця [7]. Отже, можна зробити висновок про достатньо високий рівень не тільки теоретичного закріплення, а й практичного застосування норм, що стосуються права на захист викривачів у міжнародному просторі. Та на скільки надійною є правова база захисту доброчесних інформаторів в Україні?

В Україні на цей час відсутній досить розвинутий нормативно-правовий аспект захисту викривачів. Конституційно-правовою базою для створення правових гарантій захисту викривачів є насамперед ст. 60 Конституції України, відповідно до якої «ніхто не зобов'язаний виконувати явно злочинні розпорядження чи накази». Прийнявши рішення про запровадження курсу інтенсивної боротьби з корупцією, 14 жовтня 2014 р. Верховною Радою України був прийнятий Закон України «Про запобігання корупції», в якому йшлося про утворення Національного агентства $з$ питань запобігання корупції. Крім того, вищезазначеним Законом передбачене застосування заходів забезпечення безпеки лише особам, які брали участь у кримінальному судочинстві. Стосовно права на захист викривачів під час адміністративного чи дисциплінарного провадження, то воно залишається неврегульованим. Отже, можна дійти висновку, що Закон України «Про запобігання корупції» має більш декларативний характер.

Саме через це Всеукраїнська ліга правників проти корупції, BluePrint for Free Speech, Центр протидії корупції та Центр демократії розпочали розробку реально діючого закону у майбутньому, створили ініціативну групу «Ініціатива 11» та вже 5 жовтня 2016 р. подали до Комітету з питань запобігання та протидії корупції Верховної Ради України Законопроект № 4038а «Про захист викривачів і розкриття інформації про шкоду або загрозу суспільним інтересам» [8]. Аналізуючи даний проект, варто відмітити ст.5, яка стосується захисту інформації про осіб-викривачів та прирівняних осіб та визнає їі конфіденційною, а також передбачену можливість реалізації конституційного права на захист від негативних заходів впливу з боку осіб, наділених владними повноваженнями, що включає в себе заборону особам, наділеним владними повноваженнями, застосовувати негативні заходи впливу на викривача, а також регламентує право на звернення добросовісних інформаторів до Національного агентства 3 питань запобігання корупції та на судовий захист в порядку, передбаченому Законом. Тобто у цьому Проекті наявні чіткі зміни щодо запровадження способів реалізації викривачами корупції конституційного права кожного на захист, але, на жаль, вищезазначений Закон і досі залишається неухваленим.

В експертному висновку на проект Закону України «Про захист викривачів корупціï» зазначено, що хоча й наявні певні векторні зрушення стосовно захисту whistblowers, але законопроект потребує подальшого вдосконалення та суттєвого доопрацювання, бо має досить обмежений та вузький предмет регулювання, а сфера відносин та діяльності викривачів нині не обмежується викриттям корупційних порушень та відповідного контексту захисту викривачів [8].

Висновки 3 дослідження і перспективи подальших розвідок у цьому напрямі. Підбиваючи підсумки, слід зауважити, що Конституція України містить значний обсяг норм, що регламентують право людини на захист у різноманітних його проявах. На наш погляд, винесення права на захист у його загальному розумінні $є$ необов'язковим за належного функціонування механізму захисту суспільних відносин, їх регулювання. Крім того, практична реалізація права на захист охоплює суттєво ширше коло відносин, ніж конституційний складник. Саме тому, говорячи по закріплення у Конституції України права на захист, важливо розуміти,

ISSN 2521-6473

Правова позиція, № 3 (24), 2019 
що воно лише відкриває перспективи для наступної деталізації даного права в окремих галузях законодавства та їх дослідження.

Право на захист викривачів корупції залишається відкритим для обговорення. Однак важливим аргументом «за» $є$ саме розуміння того, що корупція - це явище, яке прогресує у політичній, економічній сферах життя населення і $є$ однією з основних причин гальмування демократичного розвитку України. Викриття - це досить ефективний та водночас нескладний засіб боротьби з корупційним гнітом. Проте людина не повинна при цьому, як нині, замислюватись, чи не буде владними корупціонерами порушене ії абсолютне право на життя, на недоторканність та безпеку?

Отже, тоді як в одних країнах викривачі допомагають зекономити державі десятки мільярдів доларів, в інших, зокрема в Україні, культура викриття корупційних злочинів лише починає зароджуватися. Викривачі знаходяться у зоні ризику в суспільстві, де обмежена свобода ЗMI, а правова система є корумпованою. Паралельно питання юридичної регламентації конституційного права на захист викривачів залишається в Україні відкритим. Сьогодні пріоритетними напрямами діяльності у цій сфері залишаються акумуляція найкращих міжнародних стандартів до національного законодавства, підтримка осіб, які не «толерують» корупцію, аналіз досвіду побудови нормативно-правової бази за кордоном, а головне -психологічний аспект сприймання народом викривачів та розуміння мети їх дій.

\section{Список використаних джерел:}

1. Конституція України. Відомості Верховної Ради України (ВВР). 1996. № 30. С. 141. URL: http://zakon5.rada.gov.ua/laws/show/254\%D0\%BA/96-\%D0\%B2\%D1\%80.

2. Про запобігання корупції: Закон України від 14.10.2014 p. № 1700-VII. URL: http://zakon0.rada.gov.ua/laws/show/1700-18/page.

3. Сметаніна Н.В. Міжнародний досвід захисту викривачів корупції / Н.В. Сметаніна, І.О. Коновалова. Право і суспільство. 2018. № 3, ч. 2. С. 236-241.

4. Шостко О.Ю. Правовий захист викривачів корупційних правопорушень. Юридичний науковий електронний журнал: електрон. наук. фах. вид. 2017. № 3. С. 146-150.

5. Кримінальна конвенція про боротьбу з корупцією (ETS 173) від 27 січня 1999 року. Офіц. вісник України, 2006 р. № 44. С. 41. Ст. 2939.

6. Цивільна конвенція про боротьбу з корупцією від 4 листопада 1999 р. Офіü. вісник Украӥни, 2006 року. № 94. С. 252. Ст. 592.

7. Рішення Європейського Суду з прав людини. Guja v. Moldova №.14277/04. URL: http://www.conventious.ru/view_base.php?id=8840.

8. Законопроект № 4038а «Про захист викривачів i розкриття інформації про шкоду або загрозу суспільним інтересам». URL: http://w1.c1.rada.gov.ua/pls/zweb2/ webproc4_1?pf3511=59836.

9. Тимченко О. Захист викривачів корупції: як це працює в Україні та світі? / О. Тимченко, О. Калітенко. Радіо свобода. URL: https://www.radiosvoboda.org/a/27118580.html.

10. Дещо про міжнародний досвід у сфері захисту викривачів: Національне Агентство 3 питань запобігання корупції. URL: https:/nazk.gov.ua/news/deshcho-pro-mizhnarodnyy-dosvidu-sferizahystu-vykryvachiv.

11. The Whistleblowing Commission. Code of Practice. URL: http://www.pcaw.org.uk/ whistleblowing-commission-public-consultation. SEC-whistleblowing-benefits-foreigners-too.

12. Whistleblower Protections: A Guide. International Bar Association - Legal Policy \& Research Unit and Legal Practice Division. IBA, April 2018. 67 p. 
УДК 347.941

DOI https://doi.org/10.32836/2521-6473-2019-3-129-134

\author{
О. І. Лук’янчук, аспірант кафредри \\ цивільного права і процесу \\ Національної академії внутрішніх справ
}

\title{
ПОРЯДОК ПРИМУСОВОГО СТЯГНЕННЯ АЛІМЕНТІВ НА КОРИСТЬ БАТЬКІВ ЗА СІМЕЙНИМ ЗАКОНОДАВСТВОМ УКРАЇНИ
}

У статті розглядаються проблеми визначення порядку стягнення аліментів на утримання батьків і додаткових витрат на їх догляд та лікування. Окреслені підстави для звернення до суду щуодо стягнення аліментів на батьків. Визначено строк, з якого присуджуються аліменти. Встановлено сторони у розгляді справи про стягнення аліментів та коло інших суб' єктів, що залучаються до участі в таких категоріях судових справ. Визначені підстави для стягнення додаткових витрат на батьків, викликаних тяжкою хворобою, інвалідністю або немічністю. Розглянуто особливості стягнення витрат на догляд та лікування батьків у разі їх тяжкої хвороби або інвалідності. Встановлено, що обов'язок по утриманню та участі в додаткових витратах на батьків не залежить від рівня матеріальної забезпеченості їхніх дітей. 3'ясовано, щзо правом вимоги на своє утримання наділені винятково батьки, які можуть вимагати його як від конкретної дитини, так і від декількох або від усіх дітей.

Встановлено, що стягнення коштів на лікування та догляд передбачається як одноразово, так і протягом певного строку, отже, це може бути або конкретна сума, щчо підлягає стягненню за весь час лікування та догляду за хворим батьком, матір'ю, або ж ия сума може бути розділена, наприклад, на однакові платежі для сплати протягом конкретного періоду.

Визначено, що розмір аліментів визначається в судовому порядку залежно від матеріального та сімейного становища батьків та дітей. Розглянуто умови звільнення дочки, сина від обов'язку утримувати матір, батька з підстав їх ухилення від виконання свойх батьківських обов 'язків.

Ключові слова: сімейне право, порядок стягнення аліментів, обов'язок утримувати, утримання, аліменти, непрацездатні батьки, діти, інвалідність, повнолітні, стягнення коштів, примусове стягнення, потреби, додаткові витрати, тяжка хвороба.

O. I. Lukyanchuk. The order of maintenance enforcement for parents upon the family law of Ukraine

The article focuses on the problems of establishment of the procedure for recovery of maintenance for parents and additional costs for their care and treatment. The grounds for appealing to the court on the issue of recovery of maintenance have been outlined. The term, after which alimony is paid, has been determined. The parties to the matters concerning the recovery of maintenance as well as other parties involved in these matters have been identified. The grounds for recovery parents'additional expenses caused by serious illness, disability or frailty have been identified. The peculiarities of recovery expenses for parents'care and treatment in case of their serious illness or disability have been considered. It has been established that the obligation to maintain parents and to share additional expenses does not depend on the well-being of their children. It has been found that only parents are entitled to claim for their maintenance; the maintenance can be claimed from one child, several or all children.

It has been established that the costs for the treatment and care can be collected on a one-time basis and for a certain period of time; so it can be either a specific amount to be collected for the entire period of treatment and care of a sick father, a mother or this sum can be divided, for example, into equal payments, which are paid within a certain period.

It has been established that the amount of alimony is determined by a court, depending on the financial and marital status of parents and children. The conditions for the release of a daughter, a son from the obligation to support a mother, a father on the grounds of their fail to perform parental obligations have been considered.

Key words: family law, procedure for recovery of maintenance, duty to maintain, maintenance, alimony, incapacitated parents, feeble, disability, children, adults, recoveries, enforcement, needs, additional expenses, serious illness.

(C) О. I. Лук'янчук, 2019

ISSN 2521-6473

Правова позиція, № 3 (24), 2019 
Постановка проблеми. За нормальних умов діти добровільно допомагають своїм батькам, зокрема непрацездатним, виявляють турботу про них та піклуються. Однак там, де стабільність стосунків між батьками та дітьми порушується, перед державними органами постає завдання по забезпеченню примусового виконання цього обов'язку. На практиці під час розгляду такої категорії справ у суді батькам часто відмовляють у позовних вимогах з підстав саме недоведеності факту їх непрацездатності або потреби в матеріальній допомозі. Насамперед це пов'язано із тим, що немає чіткого роз'яснення, що законодавець розуміє під поняттям «потребує матеріальної допомоги»: який фінансовий рівень батьків буде вважатися достатнім і не потребуватиме додаткової матеріальної допомоги зі сторони їхніх дітей. Окрім цього, закон чітко встановив перелік осіб, які належать до непрацездатних, і здається логічним, що і особи похилого віку, тяжко хворі та особи з ознаками каліцтва також повинні належати до цієї категорії. Однак, на жаль, виявляється це не так, і у законі $є$ певні прогалини та недоліки стосовно цього питання.

Отже, актуальність теми цього дослідження зумовлена потребою визначення основних юридичних фактів, які дають підстави для задоволення позовних вимог щодо стягнення аліментів на утримання та додаткових витрат, викликаних тяжкою хворобою, інвалідністю або немічністю батьків.

Аналіз останніх досліджень і публікацій. У сучасній науці сімейного права питанням аліментних відносин приділяли увагу чимало вчених, зокрема: В.К. Антошкіна, Л.В. Афанасьєва, І.В. Жилінкова, В.А. Кройтор, Т.В. Малярчук, 3.В. Ромовська, Л.В. Сапейко, Ю.С. Червоний, С.Я. Фурса. Однак їх наукові праці присвячувались обов'язку батьків щодо утримання неповнолітніх дітей. Отже, $\epsilon$ необхідність розгляду проблемних питань, що стосуються порядку примусового стягнення аліментів на утримання батьків та додаткових витрат, передбачених законодавством.

Метою статті $\epsilon$ визначення порядку примусового стягнення аліментів на утримання батьків та додаткових витрат, викликаних тяжкою хворобою, інвалідністю або немічністю. Завданнями, що підлягають вирішенню для досягнення вказаної мети, є визначення: порядку, в якому розглядаються вказані справи; кола осіб, які мають право на звернення до суду із подібними позовами; низки обставин, які належать до предмета доказування.

Виклад основного матеріалу. Держава як регулятор відносин у суспільстві визначає, що утвердження почуття обов'язку перед батьками є однією з цілей регулювання сімейних відносин (ст. 1 СК України) [1]. Обов'язок повнолітніх дітей піклуватися про своїх непрацездатних батьків прямо закріплений в Основному законі нашої держави. (ст. 51 Конституції України) [2].

Незважаючи на це, іноді так трапляється, що люди непрацездатного, похилого віку, маючи вже дорослих дітей, залишаються наодинці зі своїми проблемами, розраховуючи лише на незначну державну підтримку у вигляді пенсійного забезпечення, тоді як їхні діти не лише не згадують про необхідність надання їм фінансової допомоги, а й жодним чином не проявляють турботи чи піклування про батьків.

У таких випадках держава може примусити дітей до виконання покладеного на них обов'язку шляхом стягнення аліментів на користь непрацездатних та нужденних батьків через суд [3, с. 1].

Одразу треба зазначити, якщо у ході розгляду справи в суді про стягнення аліментів 3 дочки, сина на утримання матері, батька буде встановлено, що існує рішення суду про позбавлення батька, матері батьківських прав відносно відповідачів, в позовних вимогах належить відмовити суду в повному обсязі відповідно до частини 2 статті 202 СК України. Також, якщо в ході розгляду справи суд з'ясує, що батько, матір ухилялися від виконання своїх бать- 
ківських обов'язків, дітей також можуть звільнити від обов'язку утримувати таких батьків (ст. 204 СК України) [1].

Обов'язок виплачувати аліменти батькам може бути покладено лише на повнолітніх дітей, при цьому законодавець не ставить в залежність працездатність самих дітей, як це було раніше.

Ця категорія справ розглядається в порядку позовного провадження в загальних судах першої інстанції. Такі справи можуть порушуватися за заявами батьків та їх процесуальних представників (адвокатів), опікунів, піклувальників [4, с. 629].

Потреба матеріальної допомоги полягає в тому, що батьки насамперед є непрацездатними і здебільшого інших джерел для свого існування, окрім пенсії або державної допомоги по інвалідності, не мають. Законодавець у статті 75 СК України чітко передбачив, у яких випадках особа є такою, що потребує матеріальної допомоги, а саме: якщо заробітна плата, пенсія, доходи від використання ії майна, інші доходи не забезпечують їй прожиткового мінімуму, встановленого законом [1].

Відповідно до Закону України «Про Державний бюджет України на 2019 рік» розмір прожиткового мінімуму в 2019 році на одну особу в розрахунку на місяць для осіб, які втратили працездатність, становить: з 1 січня 2019 року - 1497 гривень, з 1 липня - 1564 гривні, з 1 грудня - 1638 гривень [5].

Це найнижчий показник прожиткового мінімуму, встановленого на 2019 рік серед основних соціальних і демографічних груп населення.

3 огляду на нинішні реалії та в умовах постійного зростання вартості життя такий «прожитковий мінімум» не може забезпечити навіть звичайних життєвих потреб людини. Треба враховувати, що через життєві обставини у батьків можливі витрати, пов'язані з наймом житла, якщо свого у власності вони не мають, необхідність у застосуванні ліків та спеціального харчування у зв'язку з хронічними хворобами, тому наявність цього уявного прожиткового мінімуму за достатньо високого рівня матеріальних статків сина чи дочки не може бути формальною підставою для відмови у позові. Справедливість, як одна із засад регулювання сімейних відносин, підкаже суду, яке рішення йому належить постановити [6, с. 396].

На нашу думку, відмова суду в позовних вимогах щодо обов'язку утримувати непрацездатних батька, матір з підстави отримання ним, нею сукупного доходу, що перевищує розмір прожиткового мінімуму, допустима лише якщо вони не доведуть, що незважаючи на це, все одно потребують матеріальної допомоги.

Згідно з чинним законодавством непрацездатність пов'язується 3 пенсійним віком або з інвалідністю. Відповідно до п. б) ч. 3 ст. 37 Закону України «Про загальнообов’язкове державне пенсійне страхування» до непрацездатних членів сім’ї закон відносить зокрема батька, матір, якщо вони є особами з інвалідністю або досягли пенсійного віку, передбаченого статтею 26 цього Закону [7].

Відповідно до Закону України «Про прожитковий мінімум» до осіб, які втратили працездатність, належать: 1) особи, які досягли встановленого законом пенсійного віку; 2) особи, які досягли пенсійного віку, що дає право на призначення пенсії на пільгових умовах; 3) непрацюючі особи, визнані особами з інвалідністю в установленому порядку [8].

Ще одне тлумачення непрацездатної особи в контексті права на утримання одного 3 подружжя іншим надається у ст. 75 СК України: «непрацездатним вважається той із подружжя, який досяг пенсійного віку, встановленого законом, або є особою 3 інвалідністю I, II чи III групи» [1].

Відповідно до Закону України «Про основні засади соціального захисту ветеранів праці та інших громадян похилого віку» в Україні громадянами похилого віку визнаються особи, які досягли пенсійного віку, встановленого статтею 26 Закону України «Про загальнообов’язкове

ISSN 2521-6473

Правова позиція, № 3 (24), 2019 
державне пенсійне страхування», а також особи, яким до досягнення зазначеного пенсійного віку залишилося не більш як півтора року [9].

На практиці часто трапляються випадки, коли батько, матір, які ще не досягли пенсійного віку та не мають законного статусу особи з інвалідністю, за станом здоров'я не мають можливості самостійно себе утримувати та потребують додаткової матеріальної допомоги з боку дітей. Отже, змушені зробити висновок, що в таких випадках суд може відмовити в позовних вимогах на підставі їх недоведеності свого статусу непрацездатної особи.

Позов про стягнення аліментів батьки можуть пред’являти до одного, декількох чи всіх своїх дітей одночасно. Однак у СК України дотримується принцип рівності прав та обов'язків дітей стосовно батьків. Отже, відповідно до ч. 2 ст. 205 СК України під час визначення розміру аліментів та додаткових витрат суд бере до уваги можливість одержання утримання від інших дітей, до яких не пред’явлено позову про стягнення аліментів, дружини, чоловіка та своїх батьків [1].

Відповідно до статті 205 СК України під час визначення розміру аліментів на батьків суд визначає розмір аліментів на батьків у твердій грошовій сумі і (або) у частці від заробітку (доходу) 3 урахуванням матеріального та сімейного стану сторін. Під час визначення розміру аліментів та додаткових витрат суд бере до уваги можливість одержання утримання від інших дітей, до яких не пред'явлено позову про стягнення аліментів, дружини, чоловіка та своїх батьків [1].

Щодо розміру аліментів, то він визначається в судовому порядку залежно від матеріального та сімейного становища батьків та дітей. При цьому судом враховуються всі заслуговуючі на увагу інтереси сторін: непрацездатність батьків та їх потреба у матеріальній допомозі, матеріальне становище дітей, догляд дітей за батьками тощо. Також до уваги приймається отримання батьками пенсії, державних пільг, субсидій, наявність у батьків майна, що може приносити дохід, тощо [10].

Отже, СК України надав суду альтернативне право встановлювати розмір аліментів повністю чи частково, як в твердій грошовій сумі, так і в частці від заробітку (доходу). На вибір способу визначення розміру аліментів можуть впливати різні обставини: мінливість і нестабільність доходу, проживання за кордоном, одержання частини доходу в натуральній формі, наявність у дочки, сина необлікованих доходів, що підтверджено високим матеріальним рівнем їхнього життя, тощо.

Необхідно підкреслити, що крім зобов’язань 3 надання утримання нужденним батькам, сімейним законодавством на повнолітніх дочку, сина покладається також обов'язок брати участь у додаткових витратах на батьків; викликаних тяжкою хворобою, інвалідністю або немічністю (ст. 203 СК України) [1].

Потреба у додаткових витратах на батьків виникає на підставі такого складу юридичних фактів: 1) наявність батьківських відносин між позивачем та відповідачем; 2) непрацездатність матері, батька; 3) потреба матері, батька в матеріальній допомозі; 4) тяжка хвороба, інвалідність або немічність матері, батька; 5) витрати, пов'язані з тяжкою хворобою, інвалідністю або немічністю матері, батька.

Суд у кожному випадку до стягнення додаткових витрат підходить індивідуально.

Для задоволення судом позову батьків про стягнення 3 повнолітніх дітей коштів для сплати їх додаткових витрат необхідна наявність виняткових обставин. Щодо наявності виняткових обставин, то законодавець їх пов'язує з тяжкою хворобою, інвалідністю або немічністю.

Щодо порядку стягнення коштів на покриття витрат, пов'язаних з лікуванням та доглядом за батьками, то воно може здійснюватися одноразовим платежем, наприклад, якщо на проведення операції батьку чи матері потрібна певна сума грошей, яка може бути стягнена 3 дитини. Якщо батько чи мати потребують догляду в післяопераційний період чи період видужання від тяжкої хвороби, то такі кошти можуть стягуватися протягом певного строку. 
Якщо батьки перебувають тривалий час на лікуванні, то на ліки та догляд за ними (послуги медсестри, доглядальниці) потрібні додаткові кошти, які можуть сплачуватися періодично до моменту видужання батьків.

Судом також може бути враховано, що діти здійснюють особистий догляд за батьками, допомагають їм по господарству. Адже за відсутності такого догляду і наявності потреби в ньому він має здійснюватись іншими особами, послуги яких платні, і ці послуги мали б оплачувати діти. Водночас варто звернути увагу на те, що батьки не мають права вимагати від дітей здійснення особистого догляду за ними. Аліментні зобов’язання є винятково матеріальними відносинами.

Зауважимо, що на відміну від зобов'язання повнолітніх дітей надавати допомогу непрацездатним батькам, які їі потребують, піклування про батьків у вигляді відвідувань не забезпечено юридичними санкціями, тобто його виконання не можна здійснити примусово.

Обов'язок брати участь у додаткових витратах може виникати окремо від обов'язку щодо утримання батьків. Так, відповідно до СК України повнолітні дочка, син можуть бути притягнуті до участі в додаткових витратах незалежно від того, стягуються з них аліменти за рішенням суду чи ні.

Вимога про стягнення додаткових витрат може бути подана до суду й у тому випадку, якщо основна вимога про стягнення аліментів не пред'являлася через відсутність спору про звичайні (щоденні) витрати на утримання батьків. За одночасного розгляду вимог про стягнення аліментів і додаткових витрат суд у рішенні окремо визначає розмір коштів, стягуваних як аліменти й додаткові витрати [10].

Однак є винятки з цього правила. Відповідно до ст. 206 СК України у виняткових випадках, якщо мати, батько є тяжко хворими, інвалідами (тяжка хвороба одного з батьків, на відміну від інвалідності, сама по собі не означає, що він $є$ непрацездатним), а дитина (тобто особа, яка не досягла 18 років) має достатній дохід (заробіток), суд може постановити рішення про стягнення з неї одноразово або протягом певного строку коштів на покриття витрат, пов'язаних з лікуванням та доглядом за ними.

Виходячи із вказівки самої норми, застосовування ії і у випадку тяжкої хвороби батьків дає нам розуміння, що суд може стягнути з дитини витрати, пов'язані з лікуванням та доглядом за матір'ю, батьком, не лише за умови їх непрацездатності, адже тяжко хвора особа не завжди має статус непрацездатної. Однак кошти, що стягуватимуться з дитини, мають строго цільове призначення - покриття витрат, пов'язаних з доглядом за батьками та їхнім лікуванням.

Дитина може мати доходи від майна, отриманого в порядку спадкування, чи коли їй за рішенням суду була надана повна цивільна дієздатність та вона працює, займається підприємницькою діяльністю та має можливість утримувати своїх батьків у період їх лікування та догляду за ними.

Стягнення таких аліментів здійснюється в судовому порядку за заявою батька, матері, які $є$ позивачами у справі, а дитина - відповідачем у разі, якщо їй у порядку, визначеному законом, надана повна цивільна дієздатність, і вона може бути суб'єктом цивільних процесуальних відносин, в іншому випадку ії участь може бути представлена через законного представника.

Висновки 3 дослідження і перспективи подальших розвідок у цьому напрямі. 3 першого погляду видається, що стаття 206 СК України регулює відносини лише між неповолітніми дітьми та батьками, які тяжко хворіють або $є$ інвалідами і потребують коштів на покриття витрат, пов'язаних з лікуванням та доглядом за ними. Однак у зв'язку із тим, що дана норма розміщена саме в главі 17 СК України, що має назву «Обов’язок повнолітніх дочки, сина утримувати батьків та його виконання», вона може бути застосована і до повнолітніх дітей, причому винятковість ії застосування в такому разі не буде знаковою.

ISSN 2521-6473

Правова позиція, № 3 (24), 2019 


\section{Список використаних джерел:}

1. Сімейний кодекс України від 10.01.2002 року № 2947-III. URL: https://zakon.rada.gov.ua/ laws/show/2947-14.

2. Конституція України від 28.06.1996 року № 254к/96-BP. URL: https://zakon.rada.gov.ua/ laws/show/254к/96-вр.

3. Розгон О. Примусове стягнення аліментів на користь непрацездатних батьків. Журнал МЕH. № 5, 2010. С. 1-9.

4. Сімейне право: Нотаріат. Адвокатура. Суд : Науково-практичний посібник.: У 2 кн. / Драгнєва Л.Ю., Пульнєва., О.С., Фурса Є.І., Фурса С.Я. та ін./За заг ред. С.Я. Фурси. Київ : Видавець Фурса С.М., 2005. 876 с.; Ромовська 3.В. Українське сімейне право : підручник. Київ : Правова єдність, 2009. 500 с.

5. Закон України «Про Державний бюджет України на 2019 рік» від 28.02.2019 року № 2696-VIII. URL: https://zakon.rada.gov.ua/laws/show/2696-19.

6. Ромовська 3.В. Сімейний кодекс України: Науково-практичний коментар. Київ : Правова єдність, 2009. 432 с.

7. Закон України «Про загальнообов'язкове державне пенсійне страхування» від 09.07.2003 року № 1058-IV. URL: https://zakon.rada.gov.ua/laws/show/1058-15.

8. Закону України «Про прожитковий мінімум» від 15.07.1999 року № 966-XIV. URL: https://zakon.rada.gov.ua/laws/show/966-14.

9. Закону України «Про основні засади соціального захисту ветеранів праці та інших громадян похилого віку в Україні» від 16.12.1993 року№ 3721-XII. URL: https://zakon.rada.gov.ua/ laws/show/3721-12.

10. Постанова Пленуму ВСУ «Про застосування судами окремих норм Сімейного кодексу України при розгляді справ щодо батьківства, материнства та стягнення аліментів» від 15.05.2006 року № 3. URL: https://zakon.rada.gov.ua/laws/show/v0003700-06. 
УДК 347.121:711.1

DOI https://doi.org/10.32836/2521-6473-2019-3-135-139

К. Д. Пономаренко, здобувач кафедри цивільного права Національного університету «Одеська юридична академія»

\section{ПОНЯТТЯ ЗАБУДОВИ ЯК ФОРМИ РЕАЛІЗАЦІї ЦИВІЛЬНОГО ПРАВА НА ЗАБУДОВУ}

Стаття присвячена визначенню поняття забудови, проиес якої виступає формою реалізаиї суб'єктивного ичивільного права на забудову земельної ділянки. Визначено, щзо в юридичній літературі та законодавстві немає єдності термінології у сфері здійснення права на забудову. Проаналізовано наявні в юридичній літературі, законодавстві та технічних нормах визначення поняття «забудова». Розрізнено зміст понять «будівництво» та «забудова».

Доведено, що невпорядкованість термінологічного апарату в законах та підзаконних актах призводить до неможливості однозначного визначення сфери відносин, на які поширюється законодавство у сфері забудови, в тому числі будівельні норми, норми щзодо дозвільних та узгоджувальних процедур; порушення ієрархї̈ нормативно-правових актів, коли конкретні норми і приничии законодавчого акта не враховуються у процесі регулювання відносин у сфері забудови через неможливість ӥхнього кореспондування з нормами підзаконних актів, що виступають спеціальними в контексті регулювання конкретних видів відносин; зміщення балансу та утруднення взаємодії норм приватно- і публічно-правової спрямованості в регулюванні відносин забудови; підвищення ступеня впливу судової практики на регулювання відносин у сфері забудови, щяо зумовлює можливість регулювати конкретні відносини практично в ручному режимі.

На противагу термінології, яка використовується в публічних галузях права, визначено об'єм категорії «забудова» в иивільно-правовому розумінні, до ї̈ змісту включено вольову поведінку суб'єктів иивільного права, яка своїм результатом передбачає створення або зміну об'єктів будівництва на окремій земельній діляниі.

Ключові слова: право на забудову, реалізаџія суб'єктивного права, будівництвво.

K. D. Ponomarenko. Concept of development as a form of realization of civil law for development

The article is devoted to defining the concept of construction, the process of which is a form of realization of the subjective civil right to build a land plot. It is determined that there is no uniformity of terminology in the sphere of exercising the right to build in legal literature and legislation. The definitions of the term "development" are available in the legal literature, legislation and technical standards. The content of the concepts of "construction" and "development" is distinguished.

It is proved that the lack of terminological apparatus in laws and regulations leads to the impossibility of unambiguous definition of the sphere of relations to which the legislation in the sphere of construction, including building norms, norms concerning permitting and conciliation procedures, extends; violation of the hierarchy of normative acts, when specific norms and principles of a legislative act are not taken into account when regulating relations in the sphere of development due to the impossibility of their correspondence with norms of by-laws that act special in the context of regulating specific types of relations; shifting of balance and complication of interaction of norms of private and public-legal orientation in regulation of relations of development; increasing the impact of jurisprudence on the regulation of relationships in the field of development, which makes it possible to regulate specific relationships in almost manual mode.

In contrast to the terminology used in the public branches of law, the scope of the category "development" in the civil legal sense, including the content of the willful behavior of the subjects of civil law, which as a result involves the creation or change of construction objects for a separate land.

Key words: right to development, realization of subjective law, building.

\section{(C) К. Д. Пономаренко, 2019}

ISSN 2521-6473

Правова позиція, № 3 (24), 2019 
Постановка проблеми. Будівництво об'єктів різного призначення - невід'ємна складова частина буття сучасної людини. Так, галузь будівництва $є$ базовою на макроекономічному рівні, іiі стан свідчить про розвиток конкретного суспільства. Практично кожна людина за життя стикається з потребою в побудові певного архітектурного об'єкта або вдається до придбання об'єкта будівництва. Категорія «забудова» широко вживається в текстах нормативно-правових актів, однак зміст, що вкладається в дане поняття, не є очевидним. Коректне ж його визначення важливе для ефективної реалізації нормативних приписів, що регулюють питання реалізації права на забудову. Отже, дослідження сутності забудови є актуальним для науки цивільного права.

Стан дослідження теми. Теоретичні дослідження сутності забудови як форми реалізації суб'єктивного цивільного права на забудову майже відсутні. У той же час господарсько-правові аспекти сутності забудови досліджувалися О. Квасницькою, адміністративно-правові Р. Ярошевською, П. П'ятковим, А. Романенко, земельно-правові - О. Павленком, Д. Федчишиним. Тому метою цього дослідження є визначення поняття забудови на підставі аналізу чинного законодавства та надбань юридичної доктрини.

Виклад основного матеріалу. Термін «забудова» широко використовується і в цивільному законодавстві. Ч. 1 ст. 375 ЦК України визначає загальні засади здійснення права власника земельної ділянки на забудову, а саме «власник земельної ділянки має право не тільки зводити на ній будівлі та споруди, а й створювати закриті водойми, здійснювати перебудову, а також дозволяти будівництво на своїй ділянці іншим особам» [18]. Надалі ст. 395 ЦК України, врегульовуючи перелік речових прав, називає право користування чужою земельною ділянкою для забудови; у ст. 413 ЦК України визначено підстави виникнення права користування чужою земельною ділянкою для забудови. Одночасно ст. 90 ЗК закріплює право власників земельних ділянок зводити житлові будинки, виробничі та інші будівлі і споруди. Також у ЗК України згадується «житлова та громадська забудова» (ст. 38) [9].

Отже, в цивільному законодавстві закріплено суб'єктивне право забудови земельної ділянки (власної або чужої) з різним переліком об'єктів даного права, однак не визначено обсяг самого поняття забудови. У літературі також відмічається, що як і Цивільний, так і Земельний кодекси, розкриваючи зміст «права на забудову земельної ділянки», не враховують норми містобудівного законодавства [10, с. 68]. Слід зазначити, що профільний Закон України «Про регулювання містобудівної діяльності» серед закріплених у ст. 1 термінів не називає і не розкриває значення забудови [7]. Не містив визначення забудови і попередній Закон «Про планування та забудову територій» [5].

Відповідно до Словника української мови під забудовою мається на увазі спорудження будівель на якій-небудь ділянці [16]. Залежно від функціонального призначення забудови, характеру ділянок, орієнтації, розпланування, віку створення будівель виділяють: житлову і виробничу, малоповерхову, багатоповерхову і змішану, квартальну і вільну, рядкову і периметральну, історичну і традиційну, регулярну і іррегулярну, меридіональну і широтну, суцільну і садибну забудови тощо [3].

О. Квасницька доводить, що «забудова» $є$ комплексною категорією, оскільки одночасно застосовується в галузях земельного, цивільного, господарського, адміністративного права. На думку дослідниці, правова природа забудови не може бути розглянута лише в контексті цивільного, земельного законодавства або законодавства про охорону культурної спадщини $[10$, c. 67$]$.

Поряд із терміном «забудова» нерідко зустрічаємо й категорію «будівництво». Відповідно до термінології, що використовується в юридичній літературі (наприклад, «Земельний закон не виділяє пріоритетність житлового будівництва чи громадської забудови» [17, с. 268]; 
«Право на будівництво нерухомого майна (забудову) мають власники земельних ділянок» $[15$, с. 144]), забудова та будівництво нерідко використовуються як синоніми.

Будівництво - зведення архітектурного об'єкта, який у разі його відповідності проекту, вимогам будівельних норм, державних стандартів, норм і правил приймається в експлуатацію і підлягає реєстрації [14].

Так, О. Квасницька зазначає, що зміст забудови включає не тільки розміщення об'єктів будівництва, а й здійснення будівництва нових об'єктів, реконструкції, реставрації, капітального ремонту, впорядкування існуючих об'єктів містобудування та технічне переоснащення підприємств [10, с. 69].

Серед причин неузгодженості термінології перш за все необхідно виділити збереження пережитків радянського підходу до забудови, монополію на визначення обсягів, принципів здійснення та форми якої мала держава. Через це діяльність із забудови фактично отримала окремі правові режими в залежності від суб'єкта забудови. Так, будівництво, здійснене фізичними особами, капітальне будівництво в містах та забудова, що здійснюється комунальними і державними силами (в тому числі будівництво доріг, комунікацій тощо), отримали фактично самостійні правові режими, які існують у відриві від загальних норм цивільного права щодо здійснення права на забудову.

Немає однозначного співвідношення даних понять у чинному законодавстві. Так, згідно зі ст. 1 Закону України «Про архітектурну діяльність» під архітектурною діяльністю розуміється «діяльність зі створення об'єктів архітектури, яка включає творчий процес пошуку архітектурного рішення та його втілення, координацію дій учасників розроблення всіх складових частин проектів із планування, забудови і благоустрою територій, будівництва (нового будівництва, реконструкції, реставрації, капітального ремонту) будівель і споруд, здійснення архітектурно-будівельного контролю і авторського нагляду за їх будівництвом, а також здійснення науково-дослідної та викладацької роботи у цій сфері» [4]. Забудова і будівництво розглядаються законодавцем як окремі складові частини архітектурної діяльності в Україні. Так, ст. 4 Закону «Про архітектурну діяльність» визначає будівництво як складову частину комплексу робіт, пов'язаних зі створенням об'єкта архітектури, що охоплює нове будівництво, реконструкцію, реставрацію, капітальний ремонт об'єкта. Свідоме обрання такого підходу законодавцем підтверджується і текстом ст. 10. цього ж Закону, згідно з якою «для забезпечення під час забудови територій, розміщення і будівництва об'єктів архітектури додержання суб' єктами архітектурної діяльності затвердженої містобудівної та іншої проектної документації, вимог вихідних даних, а також із метою захисту державою прав споживачів будівельної продукції здійснюється в установленому законодавством порядку державний архітектурно-будівельний контроль та нагляд».

Згідно зі ст. 23 Закону України «Про планування та забудову територій» у поняття «будівництво» включається також, крім зазначеного, і впорядкування об'єктів містобудування, розширення та технічне переоснащення підприємств [6]. У наказі Міністерства фінансів України «Про затвердження положення (стандарту) бухгалтерського обліку «Будівельні контракти» від 28.04.2001 р. № 2055 будівництво визначено як спорудження нового об’єкта, реконструкція, розширення, добудова, реставрація і ремонт об'єктів.

Закон України «Про основи містобудування» для цілей врегулювання містобудівної діяльності використовує категорію «містобудування», включаючи в нього прогнозування розвитку населених пунктів і територій, планування, забудову та інше використання територій, проектування, будівництво об'єктів містобудування, спорудження інших об'єктів, реконструкцію історичних населених пунктів при збереженні традиційного характеру середовища, реставрацію та реабілітацію об'єктів культурної спадщини, створення інженерної та транспортної інфраструктури.

ISSN 2521-6473

Правова позиція, № 3 (24), 2019 
У підзаконних актах, таких як Державні будівельні норми (ДБН Б.1.1-14:2012, Склад та зміст детального плану території), під забудовою території розуміється розміщення будинків і споруд із зображенням їх на кресленні із зазначенням основних характеристик за функціональним призначенням (житлова, виробнича, багатофункціональна, громадська, курортна, оздоровча, дачна тощо), планувально-просторових особливостей (блокована, садибна, багатоквартирна тощо) та поверховості (висотна, багатоповерхова, середньоповерхова, малоповерхова або із зазначенням конкретної поверховості) [2].

Згідно з Державними будівельними нормами України (ДБН В.2.2-15-2005) малоповерхова забудова - забудова території одно-, дво-, триповерховими житловими будинками різних типів.

Невпорядкованість термінології, що її використовують окремі акти, призводить до негативних наслідків, серед яких - такі:

- неможливість однозначного визначення сфери відносин, на які поширюється законодавство у сфері забудови, в тому числі будівельні норми, норми щодо дозвільних та узгоджувальних процедур. Так, наприклад, спірним видається визначення об'єктів нерухомості, які можуть бути зведені в результаті забудови. Так, відповідно до Методичних рекомендацій стосовно визначення нерухомого майна, що знаходиться на земельних ділянках, право власності на які підлягає державній реєстрації, затверджених наказом Мін'юсту України від 14 квітня 2009 року № 660/56, асфальтобетонне покриття як об’єкт капітального типу, який фактично не може використовуватись без відділення від верхнього шару грунту, не вважається об'єктом нерухомості, а отже, виникає питання, чи є асфальтобетонне покриття об'єктом забудови;

- порушення ієрархії нормативно-правових актів, коли конкретні норми і принципи законодавчого акта не враховуються під час регулювання відносин у сфері забудови через неможливість їх кореспондування з нормами підзаконних актів, що виступають спеціальними в контексті регулювання конкретних видів відносин;

- зміщення балансу та ускладнення взаємодії норм приватно- і публічно-правової спрямованості в регулюванні відносин забудови;

- підвищення ступеня впливу судової практики на регулювання відносин у сфері забудови, що зумовлює можливість регулювати конкретні відносини практично в ручному режимі.

Отже, в галузях публічного права перш за все йдеться про «забудову» як комплексний вид людської діяльності, що включає в себе планування, побудову та обслуговування об'єктів будівництва на будь-якому рівні (державному, місцевому, індивідуальному), «забудову земельної ділянки» в контексті дозвільно-узгоджувальних процедур, «забудову території» в контексті реалізації функції держави та місцевого самоврядування щодо забезпечення раціонального використання земель, гармонійного розвитку міст, контролю за дотриманням технологічних, екологічних, естетичних та інших норм тощо.

У межах цивільно-правового регулювання можна говорити про обмежений зміст категорії «забудова», включаючи до ії змісту вольову поведінку суб'єктів цивільного права, яка своїм результатом передбачає створення або зміну об'єктів будівництва на окремій земельній ділянці.

\section{Список використаних джерел:}

1. Державні будівельні норми. Містобудування. Планування і забудова міських і сільських поселень (ДБН 360-92) : затверджено Наказом Держкоммістобудування від 17.04.1992, № 44. URL : http://www.uazakon.com/documents/date_3v/pg_gnglwj/index.htm.

2. Державні будівельні норми. Склад та зміст детального плану території (ДБН Б.1.1-14:2012) : затверджено Наказом Міністерства регіонального розвитку, будівництва та житлово-комунального господарства України 12.03.2012 № 107. URL : http://zakon.rada.gov.ua/ rada/show/v0107858-12. 


\section{Трибуна молодого науковця}

3. Забудова. Словопедія. URL : http://slovopedia.org.ua/44/53399/297035.html.

4. Закон України «Про архітектурну діяльність» від 20.05.1999 p. № 687-XIV. URL : https://zakon.rada.gov.ua/laws/show/687-14.

5. Закон України «Про планування та забудову територій» від 20.04 .2000 р. № 1699-III. URL : http://zakon3.rada.gov.ua/laws/show/1699-14.

6. Закон України «Про планування та забудову територій» від 20.04.2000 p. № 1699-III. URL : http://zakon3.rada.gov.ua/laws/show/1699-14.

7. Закон України «Про регулювання містобудівної діяльності» від 17.02 .2011 p. № 3038-VI. URL : http://zakon.rada.gov.ua/laws/show/3038-17.

8. Закон України «Про регулювання містобудівної діяльності» від 17.02.2011 p. № 3038-VI. URL : http://zakon.rada.gov.ua/laws/show/3038-17.

9. Земельний кодекс України від 25.10 .2001 p. № 2768-III-BP. URL : http:// zakon4.rada.gov.ua/laws/show/2768-14.

10. Квасницька О. Теоретичні та практичні аспекти забудови територій: господарсько-правовий аспект. Підприємництво, господарство і право. 2017. № 9. С. 67-71.

11. Про затвердження Порядку видачі будівельного паспорта забудови земельної ділянки : Наказ Міністерства регіонального розвитку, будівництва та житлово-комунального господарства України 05.07.2011 № 103. URL : http://zakon.rada.gov.ua/laws/show/z0902-11.

12. Про затвердження Типових регіональних правил забудови : Наказ Держбуду України від 10.12.2001 № 219. URL : http://zakon.rada.gov.ua/laws/show/z0004-02.

13. Саврук С.М. Правовий статус забудовника як головного суб'єкта права на забудову: його співвідношення із статусом замовника будівництва. Вісник господарського судочинства. 2010. № 6. С. 150-156.

14. Сафонов Ю.М. Економіко-правові основи капітального будівництва : навч. посібник. Київ : Центр учбової літератури, 2014. 239 с.

15. Саяпіна I. Законодавство та судова практика щодо будівництва (нове будівництво та реконструкція), визначення самочинного будівництва та процедура його легалізації станом на липень 2016 року. Мала енциклопедія нотаріуса. 2016. № 4(88). С. 132-150.

16. Словник української мови : в 11 томах. Том 3,1972 . С. 32.

17. Федчишин Д.В. Щодо ознак земель громадської забудови. Актуальні проблеми реформування земельних, екологічних, аграрних та господарських правовідносин : зб. тез Міжнар. наук.-практ. конф. (м. Хмельницький, 17-18 трав. 2013 р.) / Хмельниц. ун-т упр. та права. Хмельницький, 2013. С. 268-270.

18. Цивільний кодекс України від 16.01.2003 № 435-IV. URL : http://zakon4.rada.gov.ua/ laws/show/435-15. 
НОТАТКИ 